\title{
TRATAMENTO DE VINHAÇA EM REATOR ANAERÓBIO OPERADO EM BATELADA SEQÜENCIAL CONTENDO BIOMASSA IMOBILIZADA SOB CONDIÇÕES TERMOFÍLICAS E MESOFÍLICAS
}

\author{
Tese apresentada à Escola de \\ Engenharia de São Carlos da Universidade \\ de São Paulo para obtenção do Título de \\ Doutor em Engenharia Civil. Área de \\ Concentração: Hidráulica e Saneamento.
}

Orientador: Prof. Titular Dr. Eugenio Foresti

São Carlos 
"COISAS QUE OS OLHOS NÃO VIRAM, OS OUVIDOS NÃO OUVIRAM, E O CORAÇÃO SEQUER IMAGINOU, TAIS SÃO OS BENS QUE DEUS TEM PREPARADO PARA AQUELES QUE O AMAM ..." I CORINTIOS 2,9 ... E SÃO INCONTÁVEIS! 
DEDICO ESTE TRABALHO A MEU PAI, LINEU DE ASSUMPÇÃO FERREIRA RIBAS, PELO EXEMPLO QUE HERDEI DE AMOR E RESPEITO AO MEIO AMBIENTE! 


\section{Agradecimentos}

Agradeço a Deus por ter me dado saúde e coragem para caminhar até aqui. Pela oportunidade de conviver com tantas pessoas maravilhosas que jamais teria conhecido se não fosse o doutorado no SHS da EESC/USP. Agradeço a Deus pelo Prof. Eugenio Foresti que sempre fez mais que uma orientação científica do trabalho. Só quem foi ou é orientado dele ou convive com ele, pode entender o que estou relatando. Obrigada, Senhor, Meu Deus!

Agradeço ao Prof. Dr. Eugenio Foresti, pela orientação ao trabalho, pela confiança e pelos sábios conselhos! Pelo forte exemplo que levarei de justiça, humanidade, profissionalismo e respeito que se deve ter por um orientado. Pessoa competente que merece toda minha admiração. Muito obrigada, Professor!

Ao Prof. Fernando Fernández-Polanco da Universidad de Valladolid pela orientação, dedicação e por ter me recebido tão bem em seu grupo de pesquisa durante o estágio na Espanha.

À Usina da Serra situada em Ibaté/SP, pela permissão de coleta de vinhaça para o trabalho e aos funcionários que nos ajudaram nas coletas.

A todo corpo docente do SHS pela competência na transmissão e compartilhamento do conhecimento. Agradeço especialmente aos professores Dr. Luiz Daniel e Dr. Eduardo Cleto Pires pelo apoio no Programa de Aperfeiçoamento ao Ensino Superior, ao Dr. Marcelo Zaiat por ser tão prestativo nas inúmeras vezes que precisei, ao Dr. José Roberto Campos pelo entusiasmo contagiante em ministrar aulas no tema tratamento de águas residuárias, à Dra. Maria do Carmo Calijuri por ser uma coordenadora justa e Dra. Maria Bernadete Varesche pela contribuição durante a fase experimental no Laboratório de Processos Biológicos.

Aos funcionários do departamento: Pavi e Sá da secretaria de pós-graduação, Márcia Magro pela amizade, Rose e estagiários pelo recebimento bem-humorado, a Fernanda e Flavia da contabilidade.

À Profa. Elizabeth Moraes e Maria Ângela Tallarico Adorno pelo auxílio inestimável e insubstituível no laboratório...sem o trabalho competente e bem-humorado de vocês no laboratório, as teses não teriam a mesma qualidade que têm! 
À Eloísa Pozzi, Carolina Zampola, Daniele Vital Vich pelos exames e interpretações da microbiologia.

Ao Julio e Paulo do Laboratório de Saneamento pelo auxílio em algumas análises.

À Dra. Márcia Damianovic, Profa. Giovana Tommaso e Dr. Rogers Ribeiro pelas contribuições ao trabalho feitas nos Exames de Qualificação.

À Fundação de Amparo a Pesquisa do Estado de São Paulo, pelo apoio financeiro, através do Projeto Temático "Desenvolvimento, análise, aprimoramento, e otimização de reatores anaeróbios para tratamento de águas residuárias".

À Coordenação de Aperfeiçoamento de Pessoal de Nível Superior pela concessão da bolsa de doutorado e pelo financiamento do estágio de doutorado no exterior pelo Programa de Cooperação Científica Brasil/Espanha CAPES/MECD-DGU estabelecido entre o SHS-EESC/USP e a Universidad de Valladolid.

Ao Alisson Carraro Borges pelas informações e discussões referentes ao primeiro artigo que li sobre o tema, de Ruiz et al. (2001), ao carinho e amizade que contribuíram para melhorar um pouquinho as idéias iniciais deste trabalho e de minha personalidade. E, à D. Margarida de Jesus pela docilidade em servir...um grande exemplo de amor!

Aos amigos João Moreira e Leonardo Barra pelo forte apoio que jamais esquecerei!

Agradeço aos queridos amigos que conheci pela bondade divina em São Carlos: Suzy Sarzi Oliveira, Rosilene Prestes e Luis, Sávia Gavazza dos Santos, Larissa Olmo Nogueira, Denise Santos Góes, Karina Bassan Rodrigues, Érica Flávia Tiene, Lyda Patrícia Sabogal, Marcinha Mitiko Onoyama, Katt Regina Lapa e Luis Hamilton Garbossa, Claudinha Fink e Ester Carvalho de Sousa...ter convivido com vocês foi um privilégio que fez toda diferença da minha passagem em São Carlos!

Aos companheiros do Laboratório de Processos Biológicos e do Programa de Pós-Graduação em Hidráulica e Saneamento: Marcus Vallero, Andréia Buzzini, Arnaldo Sarti, Fábio Chinalia, Dalva, Estela, Bruna Soares Fernandes, Fernando Passig, Neyson Mendonça, Renata Médici, Flavinho Freire, Leonardo Damasceno, Cristina Iamamoto, Monique Salgado, Lara Steil, Karina Querne, Anderson Viana, Ana Paula Miqueleto, Jenny Rodrigues Victoria, Roberto Bezerra Junior, Alexandre Colzi, Gabriel Souto, Glauce (obrigada amiga, por ter organizado a melhor festa de defesas do SHS!), Pedro Henrique Carneiro, Flavinha Saia, Roseli, Renato Siman, Joel Pinheiro, Tininha, 
Nora Kátia Daguila, Mércia Domingues, Luciana Peixoto, Marcelo Barroso, Gunther Brucha, Thiago Zimmer, Alexandre Ono, Thiago Momenti, Gláucio Filho, Ivana Nardi, Gustavo Prado, Rodrigo Moruzzi, André Mineiro, enfim a todos!...Gente, parabéns por fazer dos "cafezinhos", os momentos científicos mais proveitosos e descontraídos que poderíamos ter no SHS!

Àqueles que foram minha família brasileira na Espanha: Luis Hamilton, Denise Mahl e Christiane Brasil...e que continuarão fazendo parte das recordações!

Aos amigos que fiz na Espanha e que guardarei no relicário do meu coração: Ángel Fernández, Pedro Pablo Nieto, Hicham, Sara Elvira, Amparo Martín, Luis Felipe, Lola e Ángel, Prof. Julián Lebrato, Concha, Leticia, Araceli, Cristina e Daniel Rincón ...pois sem saberem, significaram muito pra mim quando estive distante dos meus!

Ao grupo de vencedores, meus grandes amigos do Grupo de Partilha e Perseverança de Profissionais do Projeto Universidades Renovadas, pelo suporte espiritual e pelas nossas confraternizações: Heltinho, Eduardo (Dudu), Gustavo Madeira (Gugu), Patrícia e Rogério, Maria Helena, Aderson Zottis, Patrícia (Porto Velho), Marcelo Barroso, Talícia, Geilson, Renan, Denise Goes, Rodriguinho, Carolzinha, Justo, Fatiminha, Ana e Rosilei, Fernando Piantino, Achilles e todo PUR-São Carlos. Obrigada, pessoal!..."Um amigo fiel não tem preço, nem existe medida para pesar seu valor." Eclesiastes 6, 15.

Aos amigos do meu primeiro emprego, do Departamento de Engenharia Ambiental da Universidade Estadual do Centro-Oeste, Irati-PR, Adelena, Hélio, Jeanette Beber, Carlos Magno, Rubia Moisa e Gabriel Miranda...aprendi muito trabalhando com vocês!

Ao Departamento de Agronomia da Universidade Estadual de Maringá, especialmente aos professores Paulo Sérgio Lourenço de Freitas e José Gilberto Catunda Sales, pelo apoio e pressão bem intencionada para que eu finalizasse a tese.

E, finalmente, agradeço a minha família que mesmo distante, sempre acreditou na minha escolha. Agradeço a meus pais Lineu de Assumpção Ferreira Ribas e Eliana Maria Ribas, a meus irmãos Lineu, Joana Augusta e Sara Ferreira Ribas e, ao pequeno sobrinho Gabrielzinho Ribas Trujillo Costa. 


\section{Resumo}

RIBAS, M. M. F. (2006). Tratamento de vinhaça em reator anaeróbio operado em batelada seqüencial contendo biomassa imobilizada sob condições termofílicas e mesofílicas. Tese (Doutorado) - Escola de Engenharia de São Carlos, Universidade de São Paulo, São Carlos.

Neste trabalho, avaliou-se o uso do tratamento anaeróbio termofílico $\left(55^{\circ} \mathrm{C}\right) \mathrm{e}$ mesofílico $\left(35^{\circ} \mathrm{C}\right)$ de vinhaça de cana-de-açúcar em um reator contendo biomassa imobilizada operado em bateladas seqüenciais (ASBBR). O reator foi preenchido com matrizes de espuma de poliuretano inoculado com lodo granular de um reator UASB que era operado a $35^{\circ} \mathrm{C}$ e tratava água residuária de um abatedouro de aves. A agitação era promovida por agitador mecânico a $300 \mathrm{rpm}$. O tempo de ciclo do reator termofílico foi alterado nas diferentes fases operacionais em função das diferentes concentrações de vinhaça aplicadas, enquanto que o tempo de ciclo do reator mesofílico foi mantido em 24 horas. O monitoramento do reator foi feito determinando-se os teores de demanda química de oxigênio (DQO), acidez volátil total, alcalinidade a bicarbonato e valor do $\mathrm{pH}$ de amostras do afluente e efluente, bem como ao longo do ciclo. Foram efetuados também exames microscópicos para avaliar o desenvolvimento e alterações na composição da biomassa. Na fase de adaptação do lodo à temperatura termofílica, o reator foi alimentado com vinhaça com 0,3 a 1,0 gDQO/L, sendo que a biomassa do reator termofílico foi considerada adaptada 50 dias após a inoculação. $\mathrm{O}$ enriquecimento do reator mesofílico com biomassa metanogênica ocorreu em 21 dias. Nesse período, o reator foi alimentado com substrato à base de etanol $(2,5 \mathrm{gDQO} / \mathrm{L})$ e sais minerais. As cargas orgânicas aplicadas no reator termofílico foram 0,85, 2,54, 3,64, 4,49, 4,0, 5,7 e 5,24 gDQO/L.d e as eficiências médias de remoção de DQO foram de 43 \pm 7,9 \%, $73 \pm$ $7,0 \%, 68 \pm 19,2 \%, 78 \pm 9,0 \%, 55 \pm 10,0 \%, 46 \pm 19,0 \%$ e $75 \pm 7,5 \%$, respectivamente. O reator mesofílico foi submetido a cargas orgânicas de 2,85, 6,4, 7,9, 10,5, 22,2 e 36,0 gDQO/L.d com eficiências médias de remoção de $75 \pm 8,7 \%, 76 \pm$ $9,6 \%, 78 \pm 4,1 \%, 78 \pm 7,7 \%, 85 \pm 4,1 \%$ e $79 \pm 2,1 \%$, respectivamente. Portanto, considerando-se a eficiência de remoção de DQO, o desempenho do ASBBR no tratamento de vinhaça de cana-de-açúcar foi superior quando operado sob temperatura mesofílica. Os exames microbiológicos permitiram constatar o predomínio de arquéias metanogênicas do gênero Methanosarcina e bacilos fluorescentes quando o reator foi operado a temperatura termofílica, enquanto que células semelhantes à arquéias do gênero Methanosaeta predominaram durante a operação a temperatura mesofílica.

Palavras-chave: processo anaeróbio, ASBBR, vinhaça, termofílica, mesofílica, arquéia. 


\section{Abstract}

RIBAS, M. M. F. (2006). Vinasse treatment in anaerobic sequencing batch reactor with immobilized biomass under thermophilic and mesophilic conditions. Thesis (Doctorate) - Escola de Engenharia de São Carlos, Universidade de São Paulo, São Carlos.

In this work, the viability of the thermophilic $\left(55^{\circ} \mathrm{C}\right)$ and mesophilic $\left(35^{\circ} \mathrm{C}\right)$ anaerobic treatment of sugar cane vinasse in an anaerobic sequencing batch reactor containing immobilized biomass (ASBBR) was evaluated. The reactor was filled with polyurethane foam matrices inoculated with a granular sludge taken from an UASB reactor treating poultry slaughterhouse wastewater operating at $35^{\circ} \mathrm{C}$. The mixing was provided by means of a mechanical mixer operated at $300 \mathrm{rpm}$. During the operation at thermophilic temperatures, the cycle time of the ASBBR was changed in the different operating phases according to the influent concentration. At the mesophilic temperatures, the reactor operated at a fixed cycle time of 24 hours. Monitoring analyses included the determinations of chemical oxygen demand (COD), total volatile acids, bicarbonate alkalinity and $\mathrm{pH}$ of influent and effluent samples, and along the cycles. The microbial community development inside the reactor was monitored during all the experimental phases by means of microscopic observations. During the adaptation period, the biomass of the thermophilic reactor was fed with low concentration vinasse with 0.3 to $1.0 \mathrm{gCOD} / \mathrm{L}$. The biomass was considered adapted to the thermophilic temperature after 50 days. The enrichment of the mesophilic reactor with methanogenic biomass lasted 21 days. In this period the reactor was fed with ethanol based substrate $(2.5 \mathrm{gDQO} / \mathrm{L})$ and minerals. The applied organic loads in the thermophilic reactor were $0.85,2.16,4.59$, 3.95, 4.07, 6.0 and 5.24 gDQO/L.d reaching average removal efficiencies of $43 \pm 7.9 \%$, $73 \pm 7.0 \%, 68 \pm 19.2 \%, 78 \pm 9.0 \%, 55 \pm 10.0 \%, 46 \pm 19.0 \%$ and $75 \pm 7.5 \%$, respectively. The mesophilic reactor was able to accommodate organic loads of 2.85 , 6.4, 7.9, 10.5, 22.2 and $36.0 \mathrm{gCOD} / \mathrm{L} . \mathrm{d}$ with average removal efficiencies of $75 \pm 8.7 \%$, $76 \pm 9.6 \%, 78 \pm 4.1 \%, 78 \pm 7.7 \%, 85 \pm 4.1 \%$ and $79 \pm 2.1 \%$, respectively. Therefore, the treatment of sugar cane vinasse in the ASBBR under mesophlic temperatures performed better than at thermophilic conditions. The microbiological observations of biomass samples indicated that methanogenic Methanosarcina-like archaea and fluorescent rods predominated at thermophilic temperatures, whereas the Methanosaetalike archaea predominated in the reactor under mesophilic temperatures.

Key words: anaerobic process, ASBBR, vinasse, thermophilic, mesophilic, archeae 


\section{LISTA DE FIGURAS}

Figura 3.1 Fluxograma básico do processo de fabricação de álcool hidratado a partir do caldo.

Figura 3.2 Ciclização de uma das cadeias tetra-éter lipídicas de fitanil de $S$. solfataricus, em que o grau de ciclização aumenta de cima para baixo

Figura 3.3 Árvore filogenética universal baseado em sucessões de rRNA. A barra de balança corresponde a 0.1 mudanças por nucleotídeo.

Figura 4.1 Fluxograma do procedimento experimental em ASBBR com vinhaça de cana-de-açúcar realizado no Laboratório de Processos Biológicos da Escola de Engenharia de São Carlos da Universidade de São Paulo.

Figura 4.2 Fluxograma experimental dos ensaios complementares realizados no Departamento de Engenharia Química da Universidade de Valladolid, Espanha com água residuária semelhante à vinhaça de beterraba

Figura 4.3 Local de coleta de vinhaça - canal de saída da água residuária da Usina da Serra, em Ibaté/SP

Figura 4.4 Esquema do reator anaeróbio em batelada seqüencial.

Figura 4.5 Fotografia do sistema montado

Figura 4.6 Fotografia do ASBBR tratando substato sintético semelhante à vinhaça de beterraba.

Figura 5.1 Fase de adaptação da biomassa mesofílica a condições termofílicas.. 64

Figura 5.2 Morfologias observadas no inóculo em microscópio óptico.

Figura 5.3 Morfologias observadas na biomassa do reator ao final da fase mesofílica $\left(35^{\circ} \mathrm{C}\right)$ em microscópio óptico.

Figura 5.4 Morfologias observadas na biomassa do reator ao final da fase de adaptação em condições termofílicas $\left(55^{\circ} \mathrm{C}\right)$ em microscópio óptico.

Figura 5.5 Perfil de concentração de vinhaça, em DQO, ao longo do $48^{\circ}$ ciclo da fase I

Figura 5.6 Perfil de ácidos orgânicos ao longo do $48^{\circ}$ ciclo da fase I 
Figura 5.7 Perfil de concentração de vinhaça ao longo do $68^{\circ}$ ciclo da fase II..... 75

Figura 5.8 Perfil de ácidos orgânicos ao longo do $68^{\circ}$ ciclo da fase II ................ 76

Figura 5.9 Produção de $\mathrm{CH}_{4}$ e $\mathrm{CO}_{2}$ ao longo do $68^{\circ}$ ciclo da fase II................. 78

Figura 5.10 Perfil temporal de remoção de DQO para avaliar tempo de ciclo da fase III.

Figura 5.11 Perfil temporal de AVT e de AB para avaliar tempo de ciclo da fase III.

Figura 5.12 Perfil de concentração de vinhaça em termos de DQO ao longo do $94^{\circ}$ ciclo da fase III.

Figura 5.13 Perfil de ácidos orgânicos ao longo do $94^{\circ}$ ciclo da fase III.............. 82

Figura 5.14 Produção de $\mathrm{CH}_{4}$ e $\mathrm{CO}_{2}$ ao longo do $94^{\circ}$ ciclo da fase III................. 83

Figura 5.15 Perfil temporal de remoção de DQO para avaliar tempo de ciclo da fase IV

Figura 5.16 Perfil temporal de AVT e de AB para avaliar tempo de ciclo da fase IV.

Figura 5.17 Perfil de concentração de vinhaça em termos de DQO ao longo do $101^{\circ}$ ciclo da fase IV

Figura 5.18 Perfil de ácidos orgânicos ao longo do $102^{\circ}$ ciclo da fase IV

Figura 5.19 Produção de $\mathrm{CH}_{4}$ e $\mathrm{CO}_{2}$ ao longo do $101^{\circ}$ ciclo, fase IV.

Figura 5.20 Perfil temporal de remoção de DQO para avaliar tempo de ciclo da fase V.

Figura 5.21 Perfis temporais de AVT e de AB para avaliar tempo de ciclo da fase $\mathrm{V}$

Figura 5.22 Perfil temporal de remoção de DQO para avaliar tempo de ciclo da fase VII.

Figura 5.23 Perfil temporal de AVT e de AB para avaliar tempo de ciclo da fase VII.

Figura 5.24 Perfis de concentração de vinhaça em termos de DQO ao longo dos ciclos 185, 190 e 193 da fase VII

Figura 5.25 Perfil de ácidos orgânicos totais ao longo dos ciclos 185, 190 e 193 da fase VII

Figura 5.26 Perfis de fenol ao longo dos ciclos 185, 190 e 193 da fase VII. 
Figura 5.27 Produção de $\mathrm{CH}_{4}$ e $\mathrm{CO}_{2}$ do ciclo 185 da fase VII.............................. 94

Figura 5.28 Perfil de pH ao longo dos ciclos 185, 190 e 193 da fase VII.............. 95

Figura 5.29 Perfil de sulfato e sulfeto ao longo dos ciclos 190 e 191 da fase VII.. 96

Figura 5.30 Resultados do monitoramento da DQO afluente e efluente e eficiência de remoção de DQO no efluente durante todas as fases experimentais em condições termofílicas........................................ 98

Figura 5.31 Resultados do monitoramento do $\mathrm{pH}$ afluente e efluente durante todas as fases experimentais em condições termofílicas.

Figura 5.32 Resultados do monitoramento dos ácidos voláteis totais durante todas as fases experimentais em condições termofílicas

Figura 5.33 Resultados do monitoramento da alcalinidade a bicarbonato durante todas as fases experimentais em condições termofílicas.

Figura 5.34 Resultados do monitoramento da alcalinidade parcial durante todas as fases experimentais em condições termofílicas.

Figura 5.35 Resultados do monitoramento da alcalinidade intermediária durante todas as fases experimentais em condições termofílicas

Figura 5.36 Monitoramento da relação alcalinidade intermediária e parcial (AI/AP) durante todas as fases experimentais em condições termofílicas

Figura 5.37 Morfologias observadas por microscopia óptica de contraste de fases e fluorescência.

Figura 5.38 Morfologias observadas por microscopia óptica de contraste de fases e fluorescência

Figura 5.39 Morfologias observadas em microscopia eletrônica de varredura........

Figura 5.40 Perfis de DGGE.

Figura 5.41 Ajuste do modelo cinético de primeira ordem aos dados experimentais de decaimento de DQO sob condições termofílicas.....

Figura 5.42 Resultados do monitoramento da DQO afluente e efluente e da eficiência de remoção do reator termofílico ASBBR tratando substrato semelhante à vinhaça do processamento da beterraba 
Figura 5.43 Resultados do monitoramento da DQO afluente e efluente e da eficiência de remoção do reator termofílico com biomassa suspensa granulada tratando substrato semelhante à vinhaça do processamento da beterraba

Figura 5.44 Resultados do monitoramento da DQO afluente e efluente e da eficiência de remoção do reator mesofílico com biomassa suspensa granulada tratando substrato semelhante à vinhaça do processamento da beterraba.

Figura 5.45 Frascos - reatores com biomassa granular suspensa operado em condições termofílicas (frasco da esquerda) e mesofílicas (frasco da direita) no ciclo 42

Figura 5.46 Relação entre $\mathrm{CO}_{2}$ e $\mathrm{CH}_{4}$ do biogás do headspace dos reatores com biomassa granulada suspensa.

Figura 5.47 Produção de metano por inóculo granulado mesofílico tratando substrato semelhante à vinhaça de beterraba em $35^{\circ} \mathrm{C}$ e $55^{\circ} \mathrm{C}$

Figura 5.48 Perfil de DQO ao longo do ciclo 25, fase I, em ASBBR mesofílico...

Figura 5.49 Perfil de $\mathrm{pH}$ ao longo do ciclo 25, fase I, ASBBR mesofílico

Figura 5.50 Perfil de ácidos orgânicos ao longo do ciclo 25, fase I, ASBBR mesofílico.

Figura 5.51 Porcentagem e relação de $\mathrm{CH}_{4}$ e $\mathrm{CO}_{2}$ no biogás, fase I, ASBBR mesofílico

Figura 5.52 Perfil de DQO ao longo do ciclo 42, fase II, em ASBBR mesofílico.. 128

Figura 5.53 Perfil de pH ao longo do ciclo 42, fase II, ASBBR mesofílico.......... 128

Figura 5.54 Perfil de ácidos orgânicos, fase II, ASBBR mesofílico..................... 129

Figura 5.55 Porcentagem e relação de $\mathrm{CH}_{4}$ e $\mathrm{CO}_{2}$ no biogás, fase II, ASBBR mesofílico

Figura 5.56 Perfis de DQO ao longo dos ciclos 75 e 81, fase IV, em ASBBR mesofílico

Figura 5.57 Perfil de $\mathrm{pH}$ ao longo dos ciclos 75 e 81, fase IV, ASBBR mesofílico

Figura 5.58 Perfil de ácidos orgânicos ao longo dos ciclos 75 e 81, fase IV, ASBBR mesofílico 
Figura 5.59 Porcentagem e relação de $\mathrm{CH}_{4}$ e $\mathrm{CO}_{2}$ no biogás ao longo dos ciclos 75 e 81, fase IV, ASBBR mesofílico

Figura 5.60 Concentração de metano no biogás durante o tempo de incubação do teste de AME..

Figura 5.61 Resultados do monitoramento da DQO afluente e efluente e eficiência de remoção de DQO no efluente durante todas as fases experimentais em condições mesofílicas.

Figura 5.62 Resultados do monitoramento do $\mathrm{pH}$ afluente e efluente durante todas as fases experimentais em condições mesofílicas.

Figura 5.63 Resultados do monitoramento da alcalinidade a bicarbonato durante todas as fases experimentais em condições mesofílicas.

Figura 5.64 Resultados do monitoramento de AVT durante todas as fases experimentais em condições mesofílicas.

Figura 5.65 Monitoramento da relação alcalinidade intermediária e parcial (AI/AP) durante todas as fases experimentais em condições mesofílicas

Figura 5.66 Morfologias observadas por microscopia óptica de contraste de fases e fluorescência.....

Figura 5.67 Ajuste do modelo cinético de primeira ordem aos dados experimentais de decaimento de DQO sob condições mesofílicas......

Figura 5.68 Carga orgânica volumétrica aplicada ao ASBBR e eficiência de remoção de DQO sob condições (a) termofílicas e (b) mesofílicas.....

Figura 5.69 Eficiência de remoção média de DQO e COV aplicada em ASBBR termofílico e mesofílico.

Figura 5.70 Quantidade de bicarbonato adicionada e DQO em ASBBR termofílico e mesofílico. 


\section{LISTA DE TABELAS}

Tabela 3.1 Comparação das características da vinhaça produzida a partir do processamento e fermentação da beterraba e da cana-de-açúcar

Tabela 3.2 Comparação da taxa de crescimento máximo de alguns mesófilos e termófilos homólogos

Tabela 3.3 Comparação do tratamento anaeróbio em reator UASB alimentado com vinhaça do processamento de cana sob condições termofílicas e mesofílicas

Tabela 3.4 Principais características de inóculos usados na partida de reatores termofílicos de alguns trabalhos.

Tabela 3.5 Dados experimentais obtidos em reatores anaeróbios para tratamento da vinhaça de diversas origens.

Tabela 4.1 Parâmetros físico-químicos de três diferentes lotes de vinhaça de cana-de-açúcar coletados em maio e setembro de 2004 e em setembro de 2005 usados como afluente nos experimentos

Tabela 4.2 Composição da solução de nutrientes para processos anaeróbios.

Tabela 4.3 Características principais do lodo granulado de inóculo utilizado......

Tabela 4.4 Estratégias experimentais realizadas em etapas durante a partida e fase de adaptação do inoculo em condições termofílicas.

Tabela 4.5 Condições experimentais adotadas em cada fase após análise do tempo de ciclo para cada concentração de vinhaça em condições termofílicas.

Tabela 4.6 Condições experimentais realizadas durante o período de enriquecimento da biomassa em condições mesofílicas.

Tabela 4.7 Condições experimentais adotadas em cada fase experimental para cada concentração de vinhaça em condições mesofílicas.

Tabela 4.8 Média de três repetições e desvio padrão (DP) de amostras de DQO preparadas por diferentes procedimentos avaliados

Tabela 4.9 Fases experimentais realizadas nos ensaios com ASBBR com substrato semelhante à vinhaça de beterraba.

Tabela 4.10 Fases experimentais realizadas nos ensaios com reator de biomassa granulada suspensa. 
Tabela 5.1 Parâmetros físico-químicos de três diferentes lotes de vinhaça de cana-de-açúcar coletados em maio e setembro de 2004 e em setembro de 2005 usados como afluente nos experimentos.

Tabela 5.2 Parâmetros físico-químicos monitorados do afluente e efluente durante a fase de adaptação.

Tabela 5.3 Parâmetros físico-químicos monitorados do afluente e efluente da fase I.

Tabela 5.4 Parâmetros físico-químicos monitorados do afluente e efluente da fase II

Tabela 5.5 Parâmetros físico-químicos monitorados do afluente e efluente durante a fase III

Tabela 5.6 Parâmetros físico-químicos monitorados do afluente e efluente durante as fases IV.

Tabela 5.7 Parâmetros físico-químicos monitorados do afluente e efluente durante as fases $\mathrm{V}$.....

Tabela 5.8 Parâmetros físico-químicos monitorados do afluente e efluente da fase VI.

Tabela 5.9 Parâmetros físico-químicos monitorados no afluente e efluente da fase VII.

Tabela 5.10 Incidência de morfologias observadas durante as fases experimentais em ASBBR sob condições termofílicas.

Tabela 5.11 Valores médios de sólidos voláteis totais das espumas de poliuretano obtidos ao final das fases experimentais sob condições termofílicas

Tabela 5.12 Parâmetros cinéticos aparentes de decaimento de DQO em cada fase experimental tratando vinhaça de cana-de-açúcar em ASBBR termofílico.

Tabela 5.13 Valores médios de DQO e de eficiência de remoção em reator ASBBR termofílico tratando substrato semelhante à vinhaça de beterraba

Tabela 5.14 Valores médios de DQO e de eficiência de remoção em reator com biomassa granular suspensa tratando substrato semelhante à vinhaça de beterraba 
Tabela 5.15 Parâmetros físico-químicos monitorados no afluente e efluente na fase de enriquecimento do lodo do ASBBR mesofílico

Tabela 5.16 Parâmetros físico-químicos monitorados no afluente e efluente na fase I do ASBBR mesofílico

Tabela 5.17 Parâmetros físico-químicos monitorados no afluente e efluente na fase II do ASBBR mesofílico

Tabela 5.18 Parâmetros físico-químicos monitorados no afluente e efluente na fase III do ASBBR mesofílico.

Tabela 5.19 Parâmetros físico-químicos monitorados no afluente e efluente na fase IV do ASBBR mesofílico.

Tabela 5.20 Parâmetros físico-químicos monitorados no afluente e efluente na fase V do ASBBR mesofílico.

Tabela 5.21 Parâmetros físico-químicos monitorados no afluente e efluente na fase VI do ASBBR mesofílico.

Tabela 5.22 Incidência de morfologias observadas durante as fases experimentais em ASBBR sob condições mesofílicas.

Tabela 5.23 Valores médios de sólidos voláteis totais das espumas de poliuretano obtidos ao final das fases experimentais sob condições mesofílicas.

Tabela 5.24 Parâmetros cinéticos aparentes estimados de decaimento de DQO em cada fase experimental tratando vinhaça de cana-de-açúcar em ASBBR mesofílico.

Tabela 5.25 Quantidade de bicarbonato adicionada em relação à DQO em ASBBR termofílico e mesofílico.

Tabela 5.26 Quantidade de $\mathrm{Na}^{+}$adicionada no afluente junto com o bicarbonato em cada fase experimental nos reatores termofílico e mesofílico.......

Tabela 5.27 Parâmetros cinéticos aparentes estimados de decaimento de DQO em ASBBR termofílico e mesofílico. 


\section{LISTA DE ABREVIATURAS E SIGLAS}

ABNT - Associação Brasileira de Normas Técnicas

ASBBR - Anaerobic Sequencing Batch Biofilm Reactor

BRS - Bactérias Redutoras de Sulfato

CETESB - Companhia de Tecnologia de Saneamento Ambiental da Secretaria do Meio Ambiente do Estado de São Paulo

CONAMA - Conselho Nacional de Meio Ambiente

CNTP - Condições Normais de Temperatura e Pressão

DGGE - Eletroforese em Gel com Gradiente Desnaturante

DNA - desoxyribonucleic acid

DP - desvio padrão

EESC - Escola de Engenharia de São Carlos

EEM/IMT Escola de Engenharia Mauá do Instituto Mauá de Tecnologia

EPA - Environmental Protection Agency

EPS - Extracellular Polymeric Substances

ETE - Estação de Tratamento de Esgoto

FISH - Fluorescence In Situ Hybridization

IPH/UFRGS - Instituto de Pesquisas Hidráulicas da Universidade Federal do Rio Grande do Sul IPVA - Imposto sobre a Propriedade de Veículos Automotores

IPI - Imposto sobre Produtos Industrializados

IQE - Integral do Quadrado dos Erros

LPB - Laboratório de Processos Biológicos

MEV - Microscopia Eletrônica de Varredura

NMP - Número Mais Provável

PCR - Polymerase Chain Reaction

PRONAF - Programa Nacional de Fortalecimento da Agricultura Familiar

RAHLF - Reator Anaeróbio Horizontal de Leito Fixo

RNA - Ribonucleic acid

SHS - Setor de Hidráulica e Saneamento

TDH - Tempo de Detenção Hidráulica

UASB - Upflow Anaerobic Sludge Blanket

USP - Universidade de São Paulo 


\section{LiSTA DE SÍMBOLOS}

$\mathrm{AB}$ - Alcalinidade a Bicarbonato $\left(\mathrm{mg} \mathrm{CaCO}_{3} / \mathrm{L}\right)$

AGV - Ácidos Graxos Voláteis (por cromatografia)

$\mathrm{AI}$ - Alcalinidade Intermediária $\left(\mathrm{mg} \mathrm{CaCO}_{3} / \mathrm{L}\right)$

$\mathrm{AP}$ - Alcalinidade Parcial $\left(\mathrm{mg} \mathrm{CaCO}_{3} / \mathrm{L}\right)$

AVT - Acidez Volátil Total (mgHAc/L)

$\mathrm{C}_{\mathrm{af}}$ - Concentração do Afluente (g/L)

$\mathrm{CH}_{4}-$ Metano (L)

$\mathrm{CO}_{2}$ - Gás carbônico (L)

COT - Carbono Orgânico Total (g/L)

COV - Carga Orgânica Volumétrica (g/L.d)

$\mathrm{COV}_{\text {máx }}$ - Carga Orgânica Volumétrica Máxima (g/L.d)

$\mathrm{C}_{\text {similar }}$ - Coeficiente de similaridade (\%)

$\mathrm{C}_{\mathrm{S}}$ - Concentração do efluente $(\mathrm{g} / \mathrm{L})$

$\mathrm{C}_{\text {So }}$ - Concentração inicial (g/L)

$\mathrm{C}_{\mathrm{SR}}$ - Concentração residual do resíduo

DBO - Demanda Bioquímica de Oxigênio (g/L)

DQO - Demanda Química de Oxigênio (g/L)

$\varepsilon$ - Eficiência de remoção (\%)

$\Delta \mathrm{G}$ - Variação de energia livre de Gibbs (kJ/mole)

$\mathrm{k}_{\text {app }}^{1}$ - constante cinética aparente de primeira ordem $\left(\mathrm{h}^{-1}\right)$

kT - Energia térmica

$\mathrm{H}_{2}$ - Gás hidrogênio

$\mathrm{H}_{2} \mathrm{~S}$ - Ácido sulfídrico

$\mathrm{HCO}_{3}{ }^{-}$- Bicarbonato

$\mathrm{NaHCO}_{3}-$ Bicarbonato de sódio

$\Delta \mathrm{H}$ - Variação na entalpia $(\mathrm{kJ} / \mathrm{mole})$

$\mathrm{NH}_{3}$ - Amônia

$\mathrm{P}_{\mathrm{atm}}$ - Pressão atmosférica $(\mathrm{mmHg})$

pH - Potencial hidrogeniônico

$\mathrm{R}$ - Constante universal dos gases ( $\mathrm{kJ} /$ mole.K)

$\mathrm{R}^{2}$ - Coeficiente de correlação 
rpm - Rotações por minuto

SFT - Sólidos Fixos Totais (g/L)

$\mathrm{S} / \mathrm{X}$ - Substrato/microrganismo (kg DQO/kg SV $\mathrm{Vdicionado}_{\text {.d) }}$

SSV - Sólidos Suspensos Voláteis (g/L)

ST - Sólidos Totais (g/L)

SVT - Sólidos Voláteis Totais $(\mathrm{g} / \mathrm{L})$

$\mathrm{T}$ - Temperatura $\left(\mathrm{K}\right.$ ou $\left.{ }^{\circ} \mathrm{C}\right)$

$\mathrm{t}_{\mathrm{c}}$ - Tempo de ciclo $(\mathrm{d})$

$\mu_{\text {máx }}$ - Velocidade específica máxima de crescimeto da biomassa $\left(\mathrm{d}^{-1}\right)$

$\mathrm{V}_{\mathrm{af}}$ - Volume de afluente adicionado no reator (L)

$\mathrm{V}_{\text {út }}-$ Volume útil do reator $(\mathrm{L})$ 


\section{SUMÁRIO}

RESUMO.............................................................................. vii

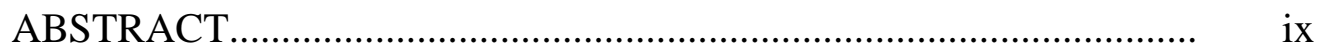

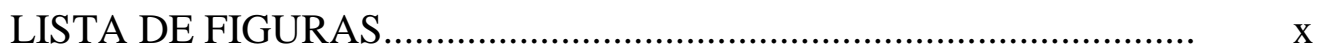

LISTA DE TABELAS.......................................................... $\mathrm{xv}$

LISTA DE SIGLAS E ABREVIATURAS......................................... x xiii

LISTA DE SÍMBOLOS......................................................... xix

$1 \quad$ INTRODUÇÃO

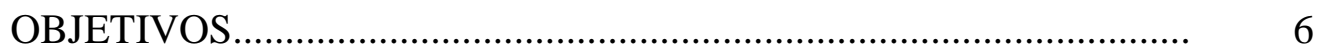

REVISÃO BIBLIOGRÁFICA..................................................... 8

3.1 Características da vinhaça................................................................. 8

3.2 Fundamentos dos processos anaeróbios termofílicos............................. 12

3.2.1 Aspectos microbiológicos e bioquímicos................................................ 13

3.2.2 Estabilidade do processo termofílico comparado ao mesofílico.............. 20

3.3 Desenvolvimento de lodo anaeróbio termofílico a partir de inóculo mesofílico................................................................................ 22

3.4 Aplicações de processos anaeróbios de tratamento de vinhaça............... 27

3.5 Vantagens e inconvenientes do tratamento anaeróbio termofílico........... 31

3.6 Considerações Finais............................................................................ 32

$4 \quad$ MATERIAL E MÉTODOS ……................................................ 34

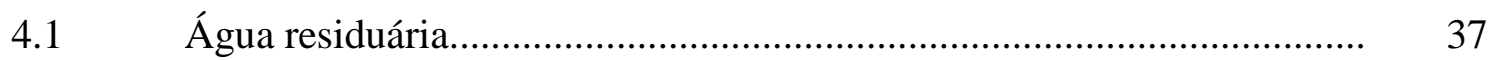

4.2 Configuração do reator.................................................................... 40

4.3 Procedimento de inoculação do reator..................................................... 43

4.3.1 Imobilização da biomassa...................................................................... 44

4.3.2 Quantificação da biomassa aderida........................................................ 44

$4.4 \quad$ Procedimento experimental............................................................. 45

4.4.1 Estimativa dos parâmetros cinéticos................................................... 45 
4.5 Partida e fase de adaptação do reator em condições termofílicas............. 46

4.6 Operação do reator condições termofílicas tratando vinhaça de canade-açúcar.

4.7 Operação do reator em condições mesofílicas tratando vinhaça de cana-de-açúcar................................................................................ 50

4.7.1 Testes de atividade metanogênica......................................................... 51

$4.8 \quad$ Análises físico-químicas................................................................... 51

4.9 Exames microbiológicos.................................................................. 53

4.10 Ensaios complementares com substrato sintético semelhante à vinhaça obtida durante o processamento de açúcar de beterraba........................ 54

4.10.1 Ensaios com biomassa imobilizada em ASBBR .................................... 55

4.10.2 Ensaios com biomassa granulada suspensa em frascos-reatores............. 57

4.10.2.1 Testes de biodegradabilidade anaeróbia................................................. 58

$5 \quad$ RESULTADOS E DISCUSSÃO

5.1 Características da vinhaça obtida do processamento de cana-de-açúcar em álcool e açúcar

5.2 Adaptação de biomassa mesofílica utilizada como inóculo em ASBBR operado em condições termofílicas.

5.3 Desempenho do reator anaeróbio termofílico $\left(55^{\circ} \mathrm{C}\right)$ operado em batelada seqüencial contendo biomassa imobilizada com aumento gradativo de carga orgânica.

5.3.1 Desempenho do reator em batelada em COV de 1,0 gDQO/L.d (fase I) e 2,5 gDQO/L.d (fase II).

5.3.2 Desempenho do reator em batelada em COV de 3,3 e 5,0 gDQO/L.d fases III a VII.

5.3.2.1 Operação do reator na fase III com 5,0 gDQO/L e COV 3,3 gDQO/L.d

5.3.2.2 Operação do reator na fase IV com 10,0 gDQO/L e COV 3,3 gDQO/L.d......

5.3.2.3 Operação do reator na fase $\mathrm{V}$ com 20,0 gDQO/L e COV 3,3 gDQO/L.d.

5.3.2.4 Operação do reator na fase VI. 
5.3.2.5 Operação do reator na fase VII com 10,0 gDQO/L e COV 5,0 gDQO/L.d.

5.3.3 Avaliação da eficiência e estabilidade do reator termofílico ao longo das fases experimentais.

5.3.4 Aspectos microbiológicos da biomassa imobilizada no reator termofílico ao longo das fases experimentais

5.3.5 Determinação dos parâmetros cinéticos aparentes sob condições termofílicas $\left(55^{\circ} \mathrm{C}\right)$......

5.4 Ensaios de biomassa anaeróbia com substrato semelhante à vinhaça do processamento de beterraba.

5.4.1 Ensaios com biomassa imobilizada em ASBBR sob condições termofílicas

5.4.2 Ensaios com biomassa granulada imobilizada em ASBBR sob condições termofílicas.

5.5 Desempenho do reator anaeróbio mesofílico $\left(35^{\circ} \mathrm{C}\right)$ operado em batelada seqüencial contendo biomassa imobilizada com aumento gradativo de carga orgânica.

5.5.1 Operação do reator na fase de enriquecimento

5.5.2 Operação do reator na fase I com COV de 2,80 gDQO/L.d.....

5.5.3 Operação do reator na fase II com COV de 6,40 gDQO/L.d....................

5.5.4 Operação do reator na fase III com COV de 7,90 gDQO/L.d.....

5.5.5 Operação do reator na fase IV com COV de 10,60 gDQO/L.d.....

5.5.6 Operação do reator na fase V com COV de 22,20 gDQO/L.d.................

5.5.7 Operação do reator na fase VI com COV de 36,0 gDQO/L.d..................

5.5.8 Avaliação da eficiência e estabilidade do reator mesofílico ao longo das fases experimentais.

5.5.9 Aspectos microbiológicos da biomassa imobilizada no reator mesofílico ao longo das fases experimentais.

5.5.10 Determinação dos parâmetros cinéticos aparentes sob condições mesofílicas $\left(35^{\circ} \mathrm{C}\right)$.

5.6 Comparação de desempenho do reator anaeróbio operado em batelada seqüencial contendo biomassa imobilizada sob condições termofílicas $\left(55^{\circ} \mathrm{C}\right)$ e mesofílicas $\left(35^{\circ} \mathrm{C}\right)$. 
5.7 Considerações finais.

CONCLUSÕES

156

7

SUGESTÕES PARA TRABALHOS FUTUROS

159

8

REFERÊNCIAS BIBLIOGRÁFICAS

161 


\section{INTRODUÇão}

"É preciso escolher um caminho que não tenha
fim, mas, ainda assim caminhar sempre na
expectativa de encontrá-lo."
Geraldo Magela Amaral

O Brasil é o maior produtor mundial no complexo sucroalcooleiro, exercendo a liderança em todos os segmentos: cana-de-açúcar, açúcar e álcool.

A produção brasileira de cana-de-açúcar está concentrada na Região Centro-Sul e o Estado de São Paulo é um dos principais pólos de produção. No Nordeste do Estado, houve significativa expansão da cana-de-açúcar, ocupando o espaço de lavouras anuais e pastagens (CARVALHO, 2006).

De acordo com dados da Embrapa, em 2005/2006, a produção de cana-de-açúcar na Região Centro-Sul foi de 336 milhões de toneladas durante a safra. A produção de açúcar, nesta mesma região, deve finalizar o ano de 2006 em 22,05 milhões de toneladas e a de álcool em 14,4 bilhões de litros.

Pagel (2006) destaca que o Brasil é considerado o país mais competitivo do mundo no setor, porque detém os maiores níveis de produtividade, rendimento e menores custos de produção. Hoje existem 329 usinas de açúcar e álcool em operação no Brasil e a expectativa é que este número salte para aproximadamente 400 unidades em 2012. Segundo o autor, a tendência de crescimento do preço mundial do petróleo, aliada à necessidade de redução de emissão de poluentes na atmosfera e ao grande volume de vendas dos veículos bicombustíveis, deverá impulsionar de forma crescente as demandas interna e externa por álcool, sendo necessário grande volume de investimentos.

Merecem destaque algumas medidas propulsoras da expansão do álcool no mercado brasileiro: (i) a obrigatoriedade do uso de $23 \%$ de álcool na gasolina (ii) os 
veículos movidos a álcool pagam um IPVA (imposto sobre a propriedade de veículos automotores) mais baixo e (iii) os veículos a álcool e flex fuel (carros bicombustíveis que podem ser abastecidos com álcool ou gasolina de acordo com a preferência do proprietário) têm redução no IPI (imposto sobre produtos industrializados). Essas medidas tiveram tanto impacto no setor automobilístico que, em fevereiro de 2006, os veículos bicombustíveis atingiram 76,6 \% das vendas totais de veículos leves (CARVALHO, 2006).

Por outro lado, a agroindústria sucroalcooleira exerce influências diretas nas áreas adjacentes às usinas, tanto no aspecto social como no ambiental, pela geração de mais de 370 mil empregos diretos, sendo responsável por aproximadamente $32 \%$ da renda agrícola paulista em empregos diretos, pela fixação do homem no campo e, pelo impacto ambiental causado, que é ampliado devido às grandes extensões de áreas monocultivadas, pelas práticas agrícolas, uso de agrotóxicos, queimada da cana-deaçúcar e pela disposição indiscriminada da vinhaça (OMETTO, 2000).

A industrialização da cana resulta na geração de grande quantidade de resíduos como bagaço, cinzas, vinhaça, outros resíduos líquidos e emissões gasosas (VACCARI et al., 2003). A maioria desses resíduos tem alto teor de matéria orgânica que, se tratada adequadamente, pode resultar em fonte potencial de energia (RAJESHWARI et al., 2000).

A vinhaça é, atualmente, um dos maiores causadores de poluição ambiental por ser o efluente originado do processo de destilação do álcool, que apresenta grande potencial poluidor. A carga poluidora é sempre elevada, mas varia em função das características da usina e da eficiência do processo de produção. Esse efluente tem elevado teor orgânico (aproximadamente $45 \mathrm{~g} / \mathrm{L}$, expressa como DQO, demanda química de oxigênio), baixo $\mathrm{pH}$ (em torno de 4,5) e elevada temperatura $\left(90{ }^{\circ} \mathrm{C}\right)$. Apresenta ainda, grande quantidade de sais minerais, com destaque ao potássio (em torno de 5,0 g/L) (WILKIE et al., 2000).

Geralmente, a vinhaça é disposta nos solos adjacentes às usinas como fertilizantes para aproveitamento dos minerais, mas só deveria ser utilizada com essa finalidade após a matéria orgânica ter sido estabilizada, devido à sua forte ação redutora (MADEJÓN et al., 2001). Este fato se agrava quando há aplicação de vinhaça no solo por longo período de tempo, por causar sobrecarga do despejo na mesma área. A poluição ambiental, neste caso, ocorre pelo excesso de sais, especialmente sais de 
potássio, e acúmulo de matéria orgânica, que representa risco de contaminação potencial para lençol freático e rios (SPRINGER \& GOISSIS, 1988).

Recentemente, em março de 2005, foi homologada a Norma Técnica CETESB P4.231 intitulada "Vinhaça: critérios e procedimentos para aplicação no solo agrícola", que tem como objetivos estabelecer os critérios e procedimentos para a aplicação de vinhaça, gerada pela atividade sucroalcooleira no processamento da cana-de-açúcar no Estado de São Paulo. A referida norma levou em consideração aspectos da Legislação Federal e Estadual, além de normas técnicas ABNT e CETESB para estabelecer os critérios e procedimentos propostos para a utilização da vinhaça (LUZ, 2005). Pela norma, as usinas instaladas no Estado de São Paulo têm prazos limites para enquadrarem suas atividades nas exigências.

No Brasil, há, desde 1978, uma Portaria do Ministério do Estado do Interior n. 323 de 1978 que proibiu a partir da safra de 1979/1980, o lançamento direto, pelas destilarias de álcool instaladas no país, de vinhaça em qualquer corpo hídrico. Tal portaria exigia que as empresas apresentassem, no prazo determinado de três meses, projetos para implantação de sistemas adequados de tratamento e/ou utilização da vinhaça visando o controle da poluição hídrica.

Os efeitos poluidores da atividade podem ser minimizados com tratamento prévio visando posterior descarte no ambiente. E, dependendo do processo empregado, o tratamento da vinhaça pode resultar no aproveitamento da carga orgânica contida nesse resíduo agroindustrial para geração de energia. Considerável atenção tem sido dada ao desenvolvimento de novas configurações de reatores anaeróbios para conversão da matéria orgânica em biogás, com a intenção de aperfeiçoar o processo.

O funcionamento de sistemas biológicos anaeróbios está ligado ao processamento da agroindústria pela geração de resíduos orgânicos que são geralmente biodegradáveis. Mas, uma das limitações de reatores biológicos anaeróbios é que pode ocorrer a inativação da biomassa em períodos de entressafra quando o reator não é utilizado, sendo necessária sua re-adaptação ou a re-inoculação do reator na safra. $\mathrm{O}$ efeito disso é mais acentuado em sistemas contínuos de tratamento anaeróbio de águas residuárias que são geradas sazonalmente como os reatores de leito fluidificado e UASB.

Outra característica relacionada à freqüência de processamento em agroindústrias é a intermitência. Neste caso, o reator batelada seqüencial tem flexibilidade operacional quanto à alimentação do reator e, por isso é comumente 
empregado em condições especiais, tais como em indústrias que produzem resíduos intermitentemente, ou quando a emissão padrão é muito restritiva ou ainda quando os resíduos contêm compostos orgânicos recalcitrantes. Nestes casos, a descarga do efluente ocorre quando sua qualidade já estiver garantida ou quando os compostos tóxicos foram degradados até se alcançarem concentrações desejadas. Sistemas que objetivam o reuso do resíduo ou a recuperação de compostos dissolvidos representam outras aplicações potenciais de reatores descontínuos. Adicionalmente, estes reatores podem ser empregados em pesquisa fundamental para elucidar alguns aspectos de degradação anaeróbia (Zaiat et al., 2001).

Devido sua flexibilidade operacional (KENNEDY et al., 1991) e à possibilidade de aplicação a diversos resíduos, o reator anaeróbio operado em bateladas seqüenciais com biomassa imobilizada, denominado ASBBR (do inglês, Anaerobic Sequencing Batch Biofilm Reactor) tem sido amplamente investigado com vários tipos de águas residuárias.

Estudos sobre a otimização do ASBBR convencional e de novas propostas de configuração de reatores vêm sendo realizados no Brasil por grupos de pesquisa da Escola de Engenharia de São Carlos da Universidade de São Paulo (EESC/USP), da Escola de Engenharia Mauá do Instituto Mauá de Tecnologia (EEM/IMT) e do Instituto de Pesquisas Hidráulicas da Universidade Federal do Rio Grande do Sul (IPH/UFRGS). Estes estudos objetivam, primordialmente, o desenvolvimento de inovações tecnológicas nesse tipo de reator, cuja configuração clássica é conhecida.

Nesse contexto, este projeto de pesquisa investigou de modo geral o desempenho do reator anaeróbio operado em batelada seqüencial contendo biomassa imobilizada para o tratamento de vinhaça de cana-de-açúcar, submetido a aumento gradativo da carga orgânica em condições termofílicas e mesofílicas, já que esse reator foi usado com sucesso no tratamento de outros tipos de despejos.

Por indisponibilidade de um inóculo termofílico, o ASBBR que foi operado a $55^{\circ} \mathrm{C}$ foi inoculado com um lodo anaeróbio procedente de um reator UASB que tratava água residuária de um abatedouro de aves a temperatura ambiente e, a viabilidade de uso desse inóculo mesofílico também foi avaliada, acompanhando-se a fase de adaptação da biomassa à maior temperatura e à vinhaça.

Após a verificação da estabilidade operacional aparente do reator em cada condição de temperatura, as eficiências quanto à remoção do conteúdo orgânico do resíduo dos dois sistemas foram avaliadas individualmente e comparadas entre si tendo 
como baliza os resultados encontrados em literatura com vinhaça de cana-de-açúcar ou de outras matérias-primas como, por exemplo, beterraba.

Além destes experimentos, dois estudos complementares foram desenvolvidos com vinhaça de beterraba, um com intuito de verificar o desempenho do ASBBR termofílico utilizando-se a biomassa anteriormente adaptada à condição termofílica que tratou vinhaça do processamento de cana-de-açúcar. E o outro, foi feito para avaliar a viabilidade da biomassa granulada incipiente, retirada do reator ascendente de manta de lodo que tratava os resíduos do abatedouro de aves, no tratamento mesofílico e termofílico. 


\section{2 ОвJеTIVOS}

"Nõo há vento favorável para aquele que não sabe aonde vai." Sêneca

\section{Objetivo geral}

Avaliar o desempenho do reator anaeróbio operado em batelada seqüencial contendo biomassa imobilizada em matrizes de espuma de poliuretano para tratamento da vinhaça em ambiente termofílico e mesofílico.

\section{Objetivos específicos}

- Avaliar o processo de adaptação de lodo mesofílico como inóculo do ASBBR termofílico no tratamento de vinhaça do processamento de cana-de-açúcar;

- Avaliar a eficiência de remoção de DQO do ASBBR mesofílico e termofílico submetido a aumento gradativo da carga orgânica de vinhaça do processamento de cana-de-açúcar;

- Identificar compostos intermediários da degradação anaeróbia de vinhaça do processamento de cana-de-açúcar em condições mesofílicas e termofílicas;

- Verificar estabilidade operacional do ASBBR mesofílico e termofílico no tratamento de vinhaça do processamento de cana-de-açúcar;

- Obter parâmetros cinéticos aparentes de degradação da matéria orgânica expressa como DQO sob condição termofílica e mesofílica no tratamento de vinhaça do processamento de cana-de-açúcar; 
- Avaliar a diversidade microbiana desenvolvida em ASBBR tratando vinhaça do processamento de cana-de-açúcar sob condições termofílicas e mesofílicas por microscopia ótica e eletrônica de varredura;

- Comparar o desempenho do reator operado sob condições termofílicas e mesofílicas no tratamento de vinhaça do processamento de cana-de-açúcar;

- Avaliar a eficiência de remoção de DQO do ASBBR termofílico no tratamento de vinhaça do processamento de beterraba inoculado com biomassa anteriormente adaptada a condições termofílicas que foi utilizada no tratamento de vinhaça de cana-de-açúcar;

- Avaliar a eficiência de remoção de DQO e a biodegradabilidade anaeróbia pelo lodo granular utilizado como inóculo em condição mesofílica e termofílica. 


\section{REVISÃo BIBLIOGRÁFICA}

"A melhor maneira de ter uma boa idéia, é ter muitas idéias." Linus Pauling

Neste capítulo serão abordados os relatos da literatura quanto à variabilidade da composição de vinhaça de diversas origens, com destaque à vinhaça de cana-de-açúcar, características que interferem no desempenho do tratamento anaeróbio. Serão apresentados, também, alguns fundamentos de processos anaeróbios termofílicos, o desenvolvimento de diferentes procedimentos de adaptação de lodo mesofílico a condições termofílicas e algumas aplicações de configurações de reatores anaeróbios para tratamento de vinhaça de cana-de-açúcar e de outras fontes de matéria-prima.

\subsection{Características da vinhaça}

O etanol pode ser obtido a partir de mostos de várias matérias-primas com alto teor de carboidratos passíveis de serem processadas e fermentadas. Tem-se, portanto, álcool de mosto de culturas ricas em açúcares (como a beterraba e a cana-de-açúcar), culturas amiláceas (milho, trigo, arroz, mandioca, aveia, etc) ou materiais celulósicos (CRUZ, 1991, WILKIE et al., 2000).

Portanto, as características da vinhaça estão intrinsecamente relacionadas ao tipo e origem da matéria-prima utilizada no processo produtivo de álcool e dependem das condições de processamento quanto à eficiência e insumos adicionados.

Wilkie et al. (2000) citam que a produção e as características da vinhaça são altamente variáveis e dependem não somente da natureza e composição da matériaprima utilizada como também do processo de produção de etanol, considerando-se a água utilizada para limpeza dos fermentadores, sistema usado no preparo do mosto, método e modo de condução de fermentação alcoólica, linhagem de levedura, tipo de 
destilador, maneira de destilação, etc. Também a água utilizada no resfriamento e na fervura pode ser descartada junto com a vinhaça, contribuindo para sua variabilidade.

Santos (2000) apresenta um fluxograma do processo de fabricação de álcool hidratado a partir da cana-de-açúcar e, portanto, da geração de vinhaça que está ilustrado na Figura 3.1.

Após a lavagem, a cana esmagada nas moendas produz caldo a ser fermentado por culturas de leveduras selecionadas para produção de etanol, geralmente Saccharomyces cerevisiae. A partir de então, o caldo passa a ser chamado de mosto.

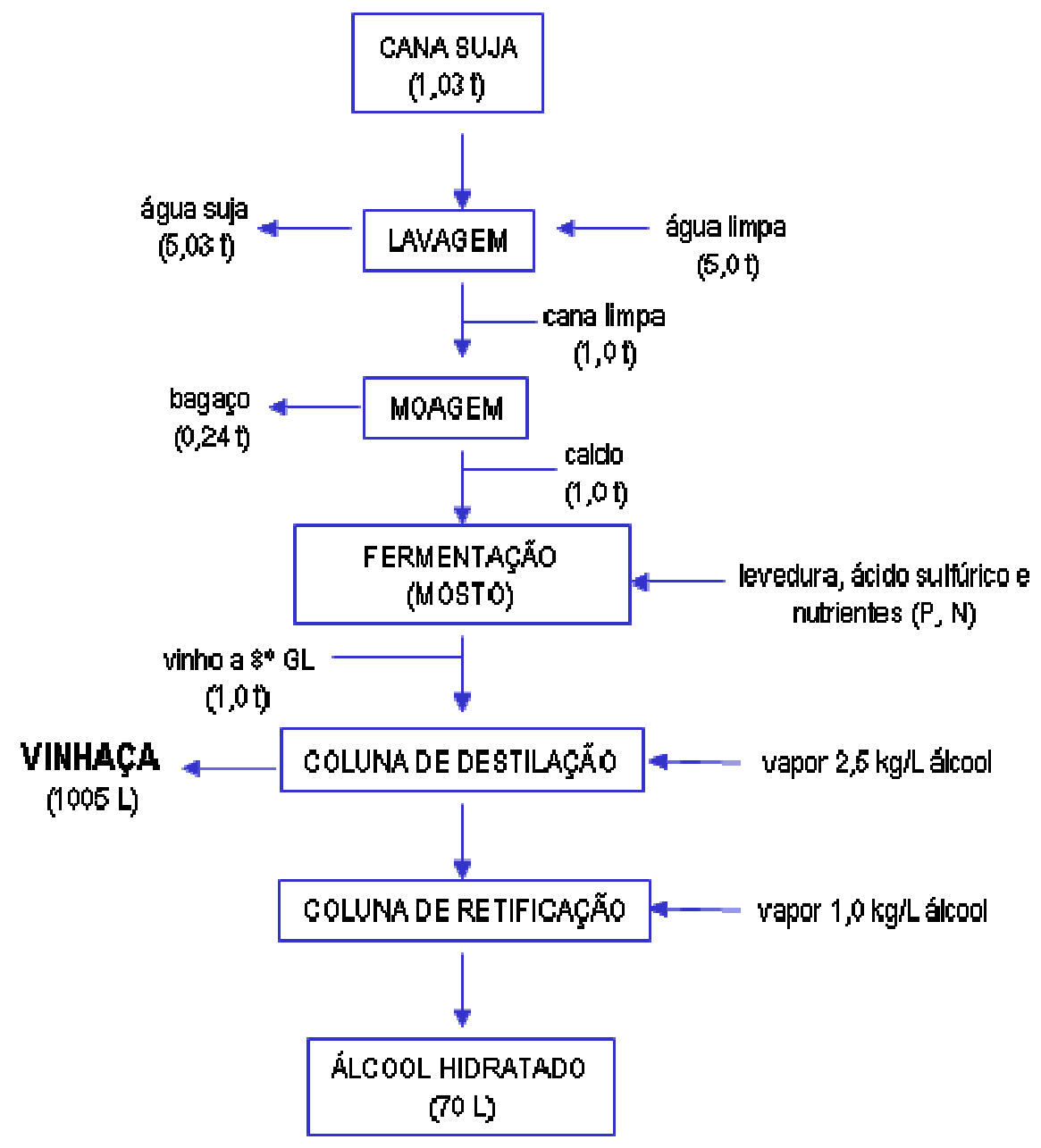

Figura 3.1 - Fluxograma básico do processo de fabricação de álcool hidratado a partir do caldo. Fonte: Santos (2000).

Segundo dados do PRONAF (2006), que é o Programa Nacional de Fortalecimento da Agricultura Familiar, o caldo de cana que sai das moendas contém gomas, graxa e cera que, juntamente com os ácidos pécticos e algumas substâncias 
nitrogenadas, formam os sólidos orgânicos do mosto. O caldo a ser fermentado, contém, ainda, materiais corantes, os pigmentos, como a clorofila, antocianinas e sacaretinas, sendo que a maior parte dessas impurezas se separa facilmente durante o aquecimento inicial do caldo, mas algumas necessitam de tratamentos que aumentam o pH do mosto, como é o caso das antocianinas que se separam em presença de óxido de cálcio (cal). Também estão presentes, em pequenas quantidades, substâncias como taninos e polifenóis, que são solúveis em água e na presença de ferro, conferem ao caldo uma coloração verde ou escura.

A fermentação é um recurso que as leveduras alcoólicas utilizam quando são impedidas de viver aerobiamente e são forçadas a viver em meio com baixa concentração de oxigênio. Os produtos deste metabolismo alternativo são o álcool e o gás carbônico, produzidos a partir da oxidação de açúcares (PRONAF, 2006). O principal álcool produzido é o etílico e a fermentação em escala industrial termina quando o teor alcoólico atinge de 7 a $9 \%$. A esse produto dá-se o nome de vinho. Dele, o etanol é separado por destilação, gerando álcool hidratado e vinhaça como produtos (VAZOLLER, 1997). Para cada $1 \%$ de açúcar residual (glicose), pode ocorrer um incremento na DQO da vinhaça de $16 \mathrm{~g} / \mathrm{L}$. Portanto, após a destilação, a vinhaça deve conter menos que 0,1 - 0,2\% de etanol (WILKIE et al., 2000).

A vinhaça é a água residuária formada na proporção média de 12,5 litros para cada litro de álcool produzido, com potencial poluidor, expresso em DQO, que pode alcançar 100 g/L (WILKIE et al., 2000).

De maneira geral, a vinhaça é composta de matéria orgânica e minerais, destacando-se o potássio e o cálcio (FERREIRA \& MONTEIRO, 1986). Mas, pode apresentar outras características importantes que causam impacto ambiental negativo, como as destacadas por Wilkie et al. (2000), que são: a cor, devido à formação de melanoidinas a partir da reação de Maillard entre açúcares e proteínas, caramelos de açúcares superaquecidos e furfurais de hidrólise ácida; a presença de metais pesados e poluentes orgânicos (como clorofórmio, pentaclorofenol, fenol e cloreto de metileno); compostos fenólicos (ácidos tânico e húmico) oriundos da matéria-prima, etc. A maioria destes compostos pode inibir a fermentação microbiana no rúmen de animais, assim como no tratamento biológico da vinhaça, quando presentes em elevadas concentrações.

Vazoller (1997) atribuiu o alto valor de matéria orgânica, que varia entre 15 e 45 g DQO/L, à presença de açúcar, etanol, glicerol e ácidos orgânicos (lático, acético e 
succínico) como sendo os principais constituintes que compõem a carga orgânica da vinhaça.

No Brasil, a produção de álcool é feita a partir do processamento da cana-deaçúcar (Saccharum officinarum), destacando-se o Estado de São Paulo como maior produtor (OMETTO, 2000). Este processo gera diversos resíduos (bagaço, flegma, vinhaça, etc) com potenciais usos porque ainda têm energia não esgotada totalmente. Já nos países europeus, o açúcar e o álcool são produzidos a partir do processamento de beterraba (Beta vulgaris L.), que forma vinhaça com características semelhantes àquela formada a partir da cana-de-açúcar (Tabela 3.1).

Tabela 3.1 - Comparação das características da vinhaça produzida a partir do processamento e fermentação da beterraba e da cana-de-açúcar.

\begin{tabular}{lcc}
\hline Parâmetro & Beterraba & Cana-de-açúcar \\
\hline pH & $5,35 \pm 1,02$ & $4,04 \pm 0,49$ \\
DBO $(\mathrm{g} / \mathrm{L})$ & $44,9 \pm 21,7$ & $16,7 \pm 3,4$ \\
$\mathrm{DQO}(\mathrm{g} / \mathrm{L})$ & $91,1 \pm 38,9$ & $30,4 \pm 8,2$ \\
$\mathrm{DBO} / \mathrm{DQO}$ & 0,49 & 0,57 \\
Sólidos totais (g/L) & $109,0^{1}$ & $52,6 \pm 28,9^{2}$ \\
Sólidos voláteis (g/L) & $79,0^{1}$ & $40,0 \pm 20,0^{2}$ \\
Sólidos fixos $(\mathrm{g} / \mathrm{L})$ & $30,0^{1}$ & $12,6 \pm 8,9^{2}$ \\
$\mathrm{~N}-$ total $(\mathrm{mg} / \mathrm{L})$ & $3569 \pm 2694$ & $628 \pm 316$ \\
$\mathrm{P}$ - total $(\mathrm{mg} / \mathrm{L})$ & $163 \pm 66$ & $130 \pm 110$ \\
$\mathrm{~K}-$ total $(\mathrm{mg} / \mathrm{L})$ & $10030 \pm 6322$ & $1952 \pm 1151$ \\
$\mathrm{SO}{ }^{-2}(\mathrm{mg} / \mathrm{L})$ & $3716 \pm 2015$ & $1356 \pm 1396$ \\
Temperatura $\left({ }^{\circ} \mathrm{C}\right)$ & 90 & 90 \\
\hline
\end{tabular}

Fonte: Wilkie et al. (2000), 'Jiménez et al. (2003), ${ }^{2}$ Driessen et al. (1994).

A produção média de vinhaça apontada por Wilkie et al. (2000) durante o procesamento da beterraba é de 11,6 L/L de etanol produzido e da cana-de-açúcar é de $16,3 \mathrm{~L} / \mathrm{L}$ de etanol.

A relação DBO/DQO informa sobre a biodegradabilidade da água residuária. Assim, um valor entre 0,3 e 0,6 que é o caso da vinhaça tanto de beterraba como de cana-de-açúcar, indica que os processos biológicos de tratamento são aplicáveis, mas pode ser necessário um tratamento prévio para corrigir algumas características.

Com relação ao pH da vinhaça, observa-se que os valores ficam entre 4,0 e 5,5. Neste contexto, a Resolução CONAMA n. 357 (2005) dispõe que os efluentes de qualquer fonte poluidora somente poderão ser lançados direta ou indiretamente, nos 
corpos de água, desde que obedeçam as condições e padrões previstos no artigo 34 que estabelece, dentre outras coisas, que o $\mathrm{pH}$ de efluentes deve estar entre 5 a 9 e temperatura inferior a $40^{\circ} \mathrm{C}$. No caso da disposição em solo, a Norma Técnica CETESB P4.231 de 2005 também exige a correção do $\mathrm{pH}$ da vinhaça para valores em torno de 6,0 e constitui um prazo de 5 anos a contar da data de publicação da norma para que as usinas se adequem às exigências estabelecidas.

Muitas alternativas de tratamento da vinhaça já foram estudadas como: tratamento em wetlands (KERNER \& ROCHARD, 2004); processos aeróbios como sistemas de lagoas (SPRINGER \& GOISSIS, 1988), lodos ativados ou reator aeróbio batelada seqüencial (TORRIJOS \& MOLETTA, 1997) e reatores anaeróbios que apresentam grande viabilidade na conversão da matéria orgânica do resíduo em biogás. Diversas configurações de reatores anaeróbios usados para esta finalidade serão relatadas mais adiante no item 3.4 deste capítulo.

É importante destacar que a vinhaça de destilaria de álcool pode ser gerada, mas não descartada ao meio ambiente, em temperatura elevada, cerca de $90{ }^{\circ} \mathrm{C}$ (HARADA et al., 1996), o que favoreceria a aplicação do tratamento anaeróbio termofílico em torno de $60{ }^{\circ} \mathrm{C}$, pois o resfriamento ocorre naturalmente durante a estocagem temporária da vinhaça em tanque de equalização ou durante o percurso até o sistema de tratamento.

Porém, atualmente, estão sendo implantados, em muitas indústrias, sistemas de aproveitamento da energia térmica do resíduo no próprio processo de produção (VACCARI et al., 2003). Portanto, com a tendência mundial crescente de implantação deste sistema, o uso de processos mesofílicos passa a ser interessante no tratamento desse despejo.

\subsection{Fundamentos dos processos anaeróbios termofílicos}

A eficiência da tecnologia de tratamento anaeróbio termofilico depende de fatores relacionados à microbiologia e bioquímica do sistema, da manutenção da estabilidade do processo e do uso de um inóculo capaz de se desenvolver sob altas temperaturas.

Os microrganismos termófilos que têm aplicação em tratamento de águas residuárias são principalmente dos Domínios Archaea e Eukarya, atuando numa faixa de temperatura ótima de $45^{\circ} \mathrm{C}$ e $60{ }^{\circ} \mathrm{C}$ (MADIGAN et al., 1998), mas podem sobreviver em amplas faixas de temperatura. 


\subsubsection{Aspectos microbiológicos e bioquímicos}

De acordo com Bitton (1994), as espécies termofílicas se desenvolvem na faixa de 50 a $75{ }^{\circ} \mathrm{C}$ ou superiores, e podem ser encontradas em águas termais, como as arquéias anaeróbias Methanothermus fervidus, que crescem na faixa de 63 a $97{ }^{\circ} \mathrm{C}$.

Van Lier (1993) classifica os microrganismos quanto à sua temperatura ótima de crescimento como: termotolerantes ou subtermofílicos, os que se desenvolvem entre 45 e $55^{\circ} \mathrm{C}$, termofílicos, os que crescem entre 55 e $70{ }^{\circ} \mathrm{C}$; termofílicos extremos, os que suportam de $70{ }^{\circ} \mathrm{C}$ a $90{ }^{\circ} \mathrm{C}$ e; hipertermofílicos, aqueles que estão presentes em ambientes cuja temperatura se encontra acima de $90{ }^{\circ} \mathrm{C}$. Todavia, o autor destaca que os extremos das faixas mencionadas são arbitrários e que, para o projeto de reatores, há que se considerar como termofílicos os microrganismos com uma temperatura ótima de crescimento superior a $45^{\circ} \mathrm{C}$.

As células vivas têm uma membrana citoplasmática que serve como barreira entre o citoplasma e o ambiente, composta por camadas de lipídio com proteínas embutidas, que geram gradientes de concentração de soluto vital e específico entre a membrana e o meio. A penetração de solutos pequenos através dos componentes lipídicos da membrana é causada pelo transporte ativo ou pela difusão passiva, sendo diretamente proporcional à energia térmica. A difusão passiva é acelerada pelo aumento da temperatura (EINSTEIN, 1905 ${ }^{1}$ apud JAENICKE \& STERNER, 2006).

Pelczar Jr. (1986) ressaltou que alguns dos fatores responsáveis pelo melhor desempenho de termófilos em elevadas temperaturas estão associados às estruturas celulares como os ribossomos, as membranas e o complexo enzimático. $\mathrm{O}$ autor citou ainda que, a perda de função da membrana citoplasmática em temperaturas mais baixas pode estar relacionada com a temperatura mínima de crescimento dos termófilos.

Brock \& Madigan (1988) esclarecem que as enzimas, as proteínas da célula, o mecanismo de síntese de proteínas pelos ribossomos e a estrutura da membrana lipídica rica em ácidos graxos saturados, que proporciona uma ligação hidrofóbica muito mais forte, são fatores que aumentam a estabilidade e resistência da membrana de termófilos e hipertermófilos ao aquecimento.

Embora alguns estudos sobre as enzimas termofílicas mostrem que há pouca diferença da seqüência de aminoácidos que catalisam a mesma reação em sistema

\footnotetext{
${ }^{1}$ Einstein, A. (1905). Über die von der molekularkinetischen Theorie der Wärme geforderte Bewegung von in ruhenden Flüssigkeiten suspendierten Teilchen. Ann. Phys., 17, 549-560.
} 
mesofílico, é observado que as enzimas e outras proteínas dos termófilos são mais estáveis ao aquecimento que as dos mesófilos, apresentando funcionamento ótimo em altas temperaturas (BROCK \& MADIGAN, 1988).

No caso dos ácidos de nucléicos de termofílicos, a modificação química (como por exemplo, a metilação de RNA) e a presença de componentes extrínsecos, promotores da estabilidade dos ácidos (tais como sais e proteínas, por exemplo, a histona), são essenciais para manter a replicação, transcrição e tradução a temperaturas próximas à de desnaturação de DNA e RNA (JAENICKE \& STERNER, 2006).

Madigan et al. (2004) também esclarecem vários fatores que garantem a termoestabilidade de biomoléculas como as proteínas e o DNA em organismos termófilos. A maioria das proteínas se desnatura em altas temperaturas, mas a composição de aminoácidos em proteínas termoestáveis identifica as propriedades destas proteínas. De fato, as enzimas de termófilos frequentemente contêm as mesmas características estruturais principais que as correspondentes termolábeis de bactérias mesófilas. No entanto, as proteínas termoestáveis tendem a apresentar núcleos altamente hidrofóbicos, o que provavelmente diminui sua tendência de se desdobrar, além de geralmente apresentarem maior interação iônica em suas superfícies. Em última análise, no entanto, a resistência térmica de uma proteína está diretamente associada ao seu dobramento. Desse modo, alterações sutis na seqüência de aminoácidos aparentemente são suficientes para conferirem termoestabilidade a proteínas antes consideradas termolábeis.

Van Lier (1993) cita que, para resistir às altas temperaturas, o DNA e RNA da maioria dos microrganismos termófilos contém mais ligações entre os aminoácidos G-C com três pontes de hidrogênio do que ligações A-T com somente duas pontes de hidrogênio. Segundo o autor, a porcentagem de ligações G-C aumenta com o aumento da temperatura ótima de crescimento. Os termófilos ainda possuem compostos que atuam como termo-estabilizadores das enzimas e dos ácidos nucléicos.

Outro fator que faz com que o DNA permaneça intacto em altas temperaturas é que o citoplasma de organismos metanogênicos termófilos contém grandes quantidades de 2,3 difosfoglicetato cíclico de potássio, que impede danos químicos, tais como a desnaturação que podem ocorrer ao DNA (MADIGAN et al., 2004).

A estrutura global dos lipídios da membrana é a mesma entre os microrganismos pertinentes aos Domínios Eukarya, Bactéria e Archaea o que pode mudar é a composição química das membranas. A membrana lipídica de arquéias é diferente em 
composição química de bactérias e de eucárias. (MADIGAN et al., 2004 e JAENICKE \& STERNER, 2006). A membrana de arquéias termófilas é composta por éter e moléculas de álcool (glicerol ou nonitol) que recebem o nome particular de caldarchaeol e formam monocamadas estáveis dispostas ao longo de toda membrana, já a membrana das bactérias termófilas é composta por ésteres e alto teor de ácidos graxos saturados (JAENICKE \& STERNER, 2006).

A membrana lipídica citoplasmática de arquéias pode ter cadeias secundárias ramificadas de hidrocarbonetos (chamadas de isoprenóides saturados, contendo um grupo de metil ligado a cada quatro átomos de carbono na cadeia) que restringem a mobilidade da cadeia, promovendo estabilização e restrição quanto à permeabilidade iônica. Os caldarchaeols podem ser modificados posteriormente por anéis de ciclopentano nas cadeias secundárias de bifitanil, processo conhecido como ciclização interna em tetraéteres dibifitanil diglicerol, ilustrado na Figura 3.2 (JAENICKE \& STERNER, 2006).

Madigan et al. (2004) explica que, virtualmente, todos os termófilos contêm lipídios construídos segundo o modelo de dibifitanil tetraéter, que são naturalmente resistentes ao calor, uma vez que as ligações covalentes entre as unidades de fitanil originam uma membrana citoplasmática do tipo monocamada lipídica em vez da bicamada lipídica usual. Essa estrutura resiste ao efeito provocado pelo calor de romper a bicamada lipídica formada por ácidos graxos.

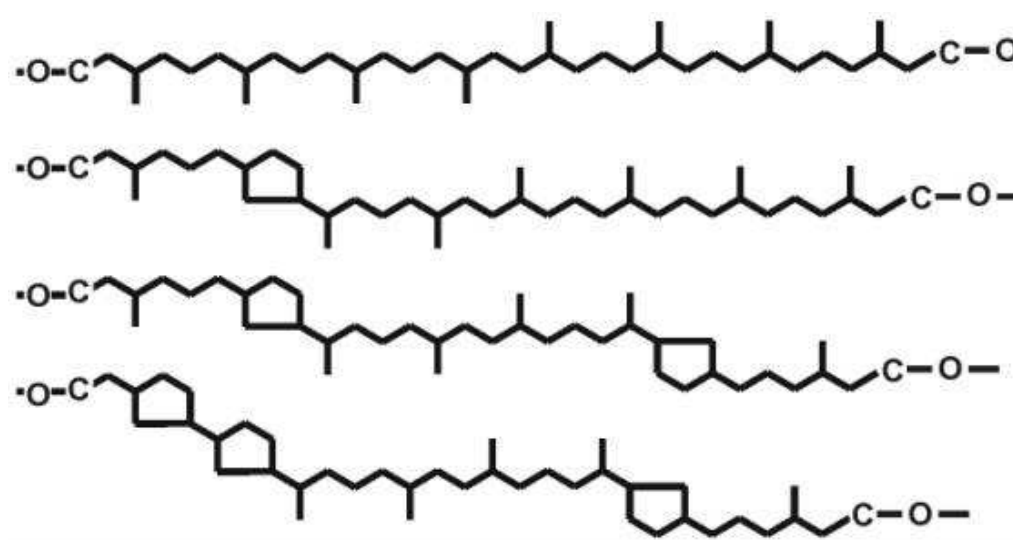

Figura 3.2- Ciclização de uma das cadeias tetra-éter lipídicas de fitanil de $S$. solfataricus, em que o grau de ciclização aumenta de cima para baixo. Fonte: Albers et al. $(2000)^{2}$ apud Jaenicke \& Sterner (2006).

\footnotetext{
${ }^{2}$ Albers, S.-J., van de Vossenberg, J. L., Driessen, A. J., Konings, W. N. (20000. Adaptations of the archaeal cell membrane to heat stress. Front. Biosci., 5, D813-D820.
} 
Ainda de acordo com Jaenicke \& Sterner (2006), bactérias e arquéias podem crescer em ampla faixa de temperaturas, mas quando enfrentam uma mudança ambiental de temperatura, a maioria delas adapta a estrutura de suas membranas para assegurar estabilidade e permeabilidade constante. Nas arquéias e bactérias, tanto mesofílicas como psicrofílicas, esta adaptação é alcançada pelo ajuste da composição química de lipídios da membrana citoplasmática. As arquéias se adaptam a altas temperaturas ciclizando (formação de anéis de ciclopentano) as cadeias de hidrocarbonetos secundárias e substituindo di-éter por tri-éter no lipídio da membrana, ou ainda, por tetra-éter que torna a membrana mais termoestável, como foi observado na arquéia Methanococcus jannaschii. Para Sulfolobus solfataricus e Thermoplasma, com o aumento da temperatura, o número de anéis de ciclopentano foi incorporado dentro das cadeias secundárias de lipídio difitanil para enrijecer a membrana e limitar a difusão passiva de moléculas pequenas.

Curiosamente, observando a riqueza de dados experimentais quanto ao repertório protéico de mesófilos e termófilos, foi comprovado que a estabilidade de proteínas de termófilos excede a de proteínas correspondentes de mesófilos. De um modo geral, a adaptação de um mesófilo em um ambiente de elevada temperatura requer a adaptação do proteoma completo à temperatura mais alta. Mas, no caso inverso, uma única mutação quanto à sensibilidade termal é suficiente. Portanto, a acumulação de termófilos extremos perto da raiz da árvore filogenética (Figura 3.3) sugere a hipótese de que os microrganismos termófilos precederam os mesófilos na história da evolução (JAENICKE \& STERNER, 2006). 


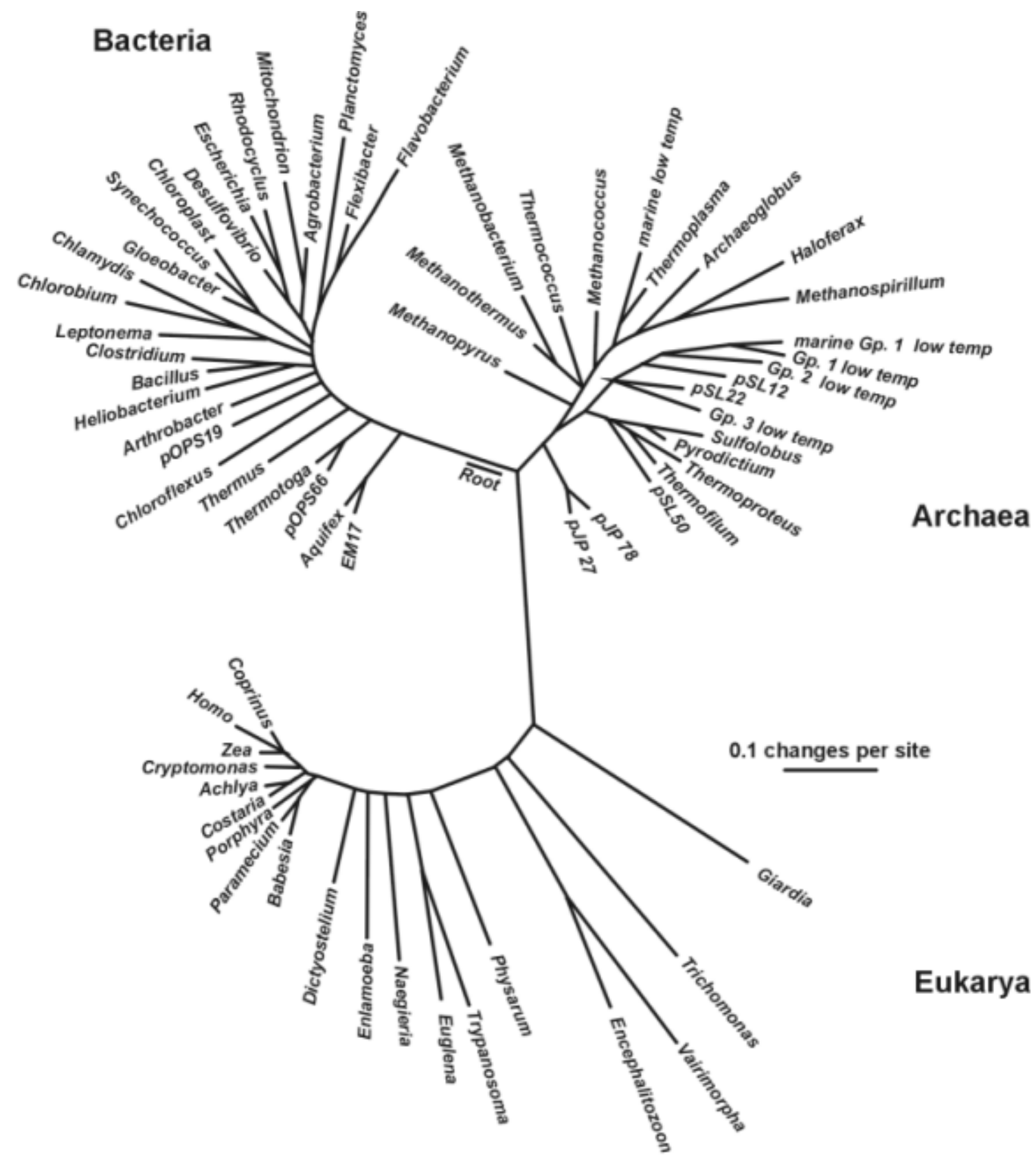

Figura 3.3 - Árvore filogenética universal baseado em sucessões de rRNA. A barra de balança corresponde a 0.1 mudanças por nucleotídeo. Fonte: Pace $(1997)^{3}$ apud Jaenicke \& Sterner (2006).

Quanto aos aspectos cinéticos, foi observado que a velocidade de crescimento dos termófilos foi da ordem de 2 a 3 vezes maior que a dos mesófilos nos processos de digestão anaeróbia. As taxas de crescimento de termófilos são geralmente maiores que de seus homólogos mesófilos (VAN LIER, 1995). A Tabela 3.2 apresenta a lista a velocidade específica máxima de crescimento das arquéias metanogênicas e bactérias

\footnotetext{
${ }^{3}$ Pace, N. R. (1997). A molecular view of microbial diversity and the biosphere. Science, 276, 734-740.
} 
acetogênicas mais importantes envolvidas na conversão anaeróbia da matéria orgânica em ambas as faixas de temperatura.

Tabela 3.2 - Comparação da taxa de crescimento máximo de alguns mesófilos e termófilos homólogos.

\begin{tabular}{llcc}
\hline \multirow{2}{*}{ Substrato } & \multirow{2}{*}{ Gênero } & \multicolumn{2}{c}{$\boldsymbol{\mu}_{\mathbf{m a ́ x}}\left(\mathbf{d}^{\mathbf{- 1}}\right)$} \\
\cline { 3 - 4 } & & Mesófilos & Termófilos \\
\hline $\mathrm{H}_{2} / \mathrm{CO}_{2}$ & Methanobacterium & 0,26 & $4,80-16,6$ \\
& Methanosaccus & $2,16-5,52$ & $18,2-51,1$ \\
& Methanobrevibacter & $0,48-1,44$ & n.a. \\
Formato & Methanobacterium & $1,44-4,08$ & 7,92 \\
Acetato & Methanosaeta & $0,44-1,92$ & 13,4 \\
& Methanosarcina & $0,24-0,67$ & $0,48-0,72$ \\
Propionato & Syntrophobacter & $0,10-0,14$ & $0,14-0,31$ \\
Butirato & Syntrophomonas & 0,36 & $0,48-0,77$ \\
\hline
\end{tabular}

n.a. dado não apresentado. Fonte: Van Lier (1995).

Aparentemente, a eficiência de crescimento de termófilos é muito menor que os seus homólogos mesófilos, característica esta que pode ser atribuída à maior necessidade de energia para manutenção em temperaturas elevadas (VAN LIER, 1995).

Em altas temperaturas, as velocidades das reações químicas e biológicas são mais rápidas que em baixas temperaturas. Porém, as reações biológicas são dependentes da temperatura ótima de crescimento dos microrganismos para que possam executar as reações. Dentro da faixa de temperatura ótima de atividade dos microrganismos, as reações de conversão termodinâmicas $(\mathrm{aA}+\mathrm{bB} \leftrightarrow \mathrm{cC}+\mathrm{dD})$ são aceleradas pelo aumento da temperatura. A variação energia livre de formação $(\Delta \mathrm{G})$ assim como $\Delta \mathrm{G}^{\mathrm{o}}$ ( $\Delta \mathrm{G}$ padrão) mudarão (Equações 3.1 e 3.2), conforme discutido por van Lier (1995):

$$
\begin{aligned}
& \frac{\Delta G_{2}}{T_{2}}-\frac{\Delta G_{1}}{T_{1}}=-\Delta H\left(\frac{T_{2}-T_{1}}{T_{1} \times T_{2}}\right) \\
& \Delta G=\Delta G^{0}+R T \times \ln \left(\frac{A^{a} \times B^{b}}{C^{c} \times D^{d}}\right)
\end{aligned}
$$

Equação 3.1

Equação 3.2

Onde, $\Delta \mathrm{G}$ significa a variação de energia livre de Gibbs $(\mathrm{kJ} / \mathrm{mole})$, T temperatura $(\mathrm{K})$, $\Delta \mathrm{H}$ variação na entalpia $(\mathrm{kJ} / \mathrm{mole}), \mathrm{R}$ constante universal dos gases $\left(8,31.10^{-3}\right.$ $\mathrm{kJ} /$ mole.K), A e B concentração de reagentes, C e D produtos e a, b, c e d coeficientes 
estequiométricos e produtos da reação. As subscrições 1 e 2 se referem a duas temperaturas diferentes.

Com base nessas informações, o autor citou que a maioria das reações de biodegradação da matéria orgânica requer menos energia para acontecer em alta temperatura, o que resulta em uma digestão mais rápida. E, lista diversas reações metanogênicas e acetogênicas, como por exemplo, a reação de conversão do bicarbonato a metano:

$$
4 \mathrm{H}_{2}+\mathrm{HCO}_{3}^{-}+\mathrm{H}^{+} \rightarrow \mathrm{CH}_{4}+3 \mathrm{H}_{2} \mathrm{O}
$$

Cujo $\Delta \mathrm{G}^{\mathrm{o}^{\prime}}$ a $25^{\circ} \mathrm{C}$ é $-135,6 \mathrm{~kJ} \cdot \mathrm{mol}^{-1}$ e $\Delta \mathrm{G}^{\prime}$ a $55^{\circ} \mathrm{C}$ é $-122,5 \mathrm{~kJ} \cdot \mathrm{mol}^{-1}$.

As arquéias metanogênicas que podem ser encontradas nos grânulos de lodo, apresentam temperatura ótima de $50{ }^{\circ} \mathrm{C}$ a $58{ }^{\circ} \mathrm{C}$ para o gênero Methanosarcina e $55^{\circ} \mathrm{C}$ e $65{ }^{\circ} \mathrm{C}$ para Methanosaeta. As Methanosarcina termofílicas tendem a perder drasticamente sua atividade ao redor de $65{ }^{\circ} \mathrm{C}$, enquanto que as Methanosaeta termofílicas ainda mantêm sua atividade nessa temperatura (ZINDER, 1988 ${ }^{4}$ apud VAZOLLER, 1997).

Quanto às características estruturais do lodo, van Lier (1993) alerta para as consequiências do aumento súbito de temperatura quando se utiliza como inóculo lodo granular mesofílico, pois a estrutura dos grânulos mesofílicos muda drasticamente em temperaturas elevadas. No lugar do grânulo original compacto, aparece uma matriz esponjosa, onde se localizam, na superfície ou nos interstícios do grânulo, os novos organismos metanogênicos termofílicos formados. Como conseqüência da elevada quantidade de biomassa mesofílica morta retida no reator, a atividade metanogênica específica aumenta lentamente. Os grânulos originais se deterioram e a mistura líquida dentro do reator se torna completamente acidificada, o que pode provocar o arraste da biomassa termofílica ativa e, ainda, há o aparecimento de material gelatinoso, como polissacarídeos, nos grânulos metanogênicos que podem ser formados por bactérias acidificantes.

Diante do exposto, pode-se inferir que um incremento na temperatura de condições mesofílicas a termofílicas provoca mudança na população microbiana de um inóculo mesofílico e que a adaptação de mesófilos é rara em altas temperaturas porque a tolerância térmica é pequena (VAN LIER, 1993).

\footnotetext{
4 Zinder, S.H. (1988). Conversion of acetic acids to methane by thermophiles. In.: International Symposium on Anaerobic Digestion, 5. Proceedings. Bologna, Itália, 1 -12.
} 


\subsubsection{Estabilidade do processo termofílico comparado ao mesofílico}

A estabilidade do lodo termofílico depende da sua diversidade microbiana, da concentração de substrato no reator e da estrutura da biomassa, que pode ser do tipo granular ou dispersa. A atividade específica máxima do lodo granular é limitada pela difusão do substrato no interior do grânulo.

De acordo com trabalhos de van Lier et al. (1993), a temperatura ótima para conversão do substrato com lodo termofílico depende das condições operacionais do reator. Em reatores UASB (do inglês, upflow anaerobic sludge blanket, significa de fluxo ascendente de manta de lodo) que têm elevada velocidade e longos tempos de retenção celular, a temperatura ótima para a conversão do acetato está em $60{ }^{\circ} \mathrm{C}$ e $65^{\circ} \mathrm{C}$, mas se o reator é do tipo mistura perfeita a maior atividade dos microrganismos metanogênicos acetotróficos situa-se na faixa mais ampla de $45{ }^{\circ} \mathrm{C}$ a $65{ }^{\circ} \mathrm{C}$. As metanogênicas com maior velocidade de crescimento pertencem ao gênero Methanosarcina, mas por terem afinidade pelo substrato relativamente mais baixa que as do gênero Methanosaeta, não devem ser selecionadas quando se trabalha com baixas concentrações de substrato.

As Methanosaeta ainda apresentam melhores propriedades de aderência por serem formadas por grandes filamentos e não terem superfície carregada a $\mathrm{pH}$ neutro. Portanto, o autor observou que o lodo granular anaeróbio de reatores UASB é, em sua maioria, dominado pela presença de arquéias do gênero Methanosaeta sob condições mesofílicas ou termofílicas, pois em reatores de fluxo contínuo as arquéias do gênero Methanosarcina são arrastadas do reator (VAN LIER, 1996).

Em ampla revisão bibliográfica sobre o tratamento anaeróbio de vinhaça de diversas origens, Wilkie et al. (2000) compararam o desempenho da digestão termofílica $\left(55{ }^{\circ} \mathrm{C}\right)$ em relação à digestão mesofílica $\left(30{ }^{\circ} \mathrm{C}\right)$ no tratamento de vinhaça em reatores anaeróbios de fluxo ascendente e manta de lodo. Os autores concluíram que o tratamento termofílico da vinhaça alcançou a eficiência de remoção de DBO quando submetido a quase o dobro da carga orgânica do sistema mesofílico, enquanto que a eficiência média de tratamento termofílico de remoção de DQO foi menor que a do mesofílico submetido à metade da carga orgânica (Tabela 3.3). Esta diferença foi atribuída pelos autores às variações na DQO refratária de vinhaças e confirmada pelos menores rendimentos de produção de metano. 
Portanto, a digestão termofílica de vinhaça, que possibilita uso de reatores menores com altas velocidades de conversão, pode ser mais tolerante a sobrecargas orgânicas do que a mesofílica, quando em reator contendo biomassa imobilizada, como os filtros anaeróbios, por permitirem a operação com elevada concentração de biomassa dentro do reator e garantirem a estabilidade do processo (WILKIE et al., 2000).

Tabela 3.3 - Comparação do tratamento anaeróbio em reator UASB alimentado com vinhaça do processamento de cana sob condições termofílicas e mesofílicas.

\begin{tabular}{lccccc}
\hline Temperatura & $\begin{array}{c}\mathbf{C O V}^{\mathbf{1}} \\
(\mathrm{g} \text { DQO/L/dia) }\end{array}$ & $\begin{array}{c}\boldsymbol{\varepsilon}_{\text {DBo }}{ }^{\mathbf{2}} \\
(\%)\end{array}$ & $\begin{array}{c}\boldsymbol{\varepsilon}_{\text {DQO }} \\
(\%)\end{array}$ & $\begin{array}{c}\text { Rendimento } \\
\left(\mathrm{LCH}_{4} / \text { gDQO) }\right.\end{array}$ & $\begin{array}{c}\text { Produção } \\
\mathbf{C H}_{\mathbf{4}} \text { (L/L.dia) }\end{array}$ \\
\hline $\begin{array}{c}\text { Mesofílica } \\
\left(25-35^{\circ} \mathrm{C}\right)\end{array}$ & $12,25 \pm 5,72$ & $79,3 \pm 13,0$ & $71,20 \pm 9,3$ & $0,26 \pm 0,06$ & $3,84 \pm 1,85$ \\
$\begin{array}{c}\text { Termofílica } \\
\left(50-60^{\circ} \mathrm{C}\right)\end{array}$ & $23,50 \pm 2,68$ & $89,2 \pm 1,4$ & $60,73 \pm 14,1$ & $0,17 \pm 0,05$ & $3,37 \pm 2,35$ \\
\hline${ }^{1} \mathrm{COV}$ - carga orgânica volumétrica, ${ }^{2} \varepsilon$ - eficiência de remoção. Fonte: Vlissidis \& Zouboulis \\
$(1993)$.
\end{tabular}

As fases de hidrólise e acidogênese do tratamento anaeróbio sob condições termofílicas e mesofílicas foram avaliadas em águas residuárias de indústrias alimentícias com alto conteúdo de sólidos orgânicos e proteína por Guerreiro et al. (1999). Os autores concluíram que o sistema é menos estável em altas temperaturas devido à maior susceptibilidade a variações na temperatura, potencializada com as interrupções na alimentação e cargas de choque. Neste caso, outro fator importante é o possível efeito tóxico da amônia livre que é mais facilmente dissociada.

Com relação à estabilidade e estruturação do lodo anaeróbio sob condições de elevada temperatura, sabe-se que a baixa viscosidade e a eventual ocorrência de agregados termofílicos menos estáveis podem dificultar a separação do lodo (VAN LIER et al., 1997).

Vários fatores podem ser responsáveis pela menor estabilidade e resistência ao rompimento de agregados anaeróbios sob condições termofílicas, como a alta taxa de mineralização do lodo, ruptura das associações sintróficas dos grânulos (VAN LIER et al., 1996), ausência de formação de polímeros extracelulares, que são produzidos notadamente por bactérias acidogênicas e arquéias metanogênicas do gênero Methanosaeta para agregação (QUARMBY \& FORSTER, $1995^{5}$ apud CARMO, 2004).

\footnotetext{
${ }^{5}$ Quarmby, J., Forster, C.F. (1995). A comparative study of the structure of thermophilic and mesophilic anaerobic granules. Enzyme and Microbial Technology. 17, 493-498.
} 
Outros aspectos importantes a serem considerados em termofilia são as propriedades físico-químicas do meio de reação que dependem da temperatura, pois $(i)$ a viscosidade do líquido diminui com o aumento da temperatura, o que implica uma melhor sedimentabilidade das partículas a altas temperaturas, (ii) a solubilidade dos gases diminui com o aumento da temperatura; conseqüentemente, haverá menores concentrações de metano no efluente, bem como de $\mathrm{H}_{2}, \mathrm{NH}_{3}$ e $\mathrm{H}_{2} \mathrm{~S}$, que exercem um efeito negativo (muitas vezes tóxicos) sobre o processo de digestão e que são mais facilmente eliminados da solução e, (iii) o equilíbrio químico e as constantes de dissociação são afetadas pela temperatura, uma vez que maiores quantidades de sais tornam-se solúveis a temperaturas mais elevadas (VAN LIER, 1993).

\subsection{Desenvolvimento de lodo anaeróbio termofílico a partir de inóculo mesofílico}

No caso de indisponibilidade de inóculo anaeróbio termofílico para partida de um reator, há possibilidade de desenvolver uma população termófila a partir de lodo anaeróbio mesofílico. Muitos estudos enfocaram estratégias para viabilizar a mudança de temperatura operacional de reatores e desenvolver a população microbiana capaz de crescer em temperaturas mais altas.

Van Lier (1993) citou que o start-up de sistemas termofílicos pode ser realizado com todo tipo de material (como dejetos de bovinos, composto, lodo granular mesofílico, lodo de estações de tratamento anaeróbio de esgoto, etc) que possua razoável atividade de lodo em temperatura mesofílica, pois, com o aumento da temperatura, a população mesofílica é gradualmente substituída por microrganismos termofílicos. Segundo estudos do autor com lodo anaeróbio granular incubado a $45^{\circ} \mathrm{C}$, $55^{\circ} \mathrm{C}$ e $65^{\circ} \mathrm{C}$, um salto de temperatura produziu diminuição brusca da eficiência, especialmente na degradação de proprionato, que resultou em coeficiente de decaimento celular de microrganismos metanogênicos de $0,44 \mathrm{~h}^{-1}$. A $55^{\circ} \mathrm{C}$ e a $65{ }^{\circ} \mathrm{C}$, toda a atividade foi irrecuperavelmente interrompida em menos de meia hora após o aumento repentino de temperatura.

Durante a seleção de inóculo mesofílico para um reator anaeróbio termofílico, além de ótima atividade metanogênica, o lodo deve apresentar ampla diversidade microbiana, fundamental para garantir a possibilidade de se encontrar microrganismos termófilos ou termotolerantes. 
Chen (1983) objetivando determinar a concentração de termófilos anaeróbios em um reator mesofílico alimentado com lodo primário municipal e examinar as capacidades de adaptação de várias subpopulações de microrganismos anaeróbios a temperaturas termofílicas retirados de reatores mesofilicos que tratava lodo primário municipal em temperaturas termofílicas, observou que apenas $10 \%$ da população metanogênica mesófila total, contado em número de colônias por mililitro utilizado, era capaz de sobreviver em ambiente termofílico, sendo que $9 \%$ eram termófilos $\left(50^{\circ} \mathrm{C}\right)$ e $1 \%$ termófilos obrigatórios $\left(60^{\circ} \mathrm{C}\right)$.

O autor verificou que, do total (de $10 \%$ ), $9 \%$ era termófilos e $1 \%$ termófilos obrigatórios que cresceram em $\mathrm{H}_{2}$ e $\mathrm{CO}_{2} ; 8 \%$ termófilos e $5 \%$ termófilos obrigatórios que cresceram com formiato; e $25 \%$ termófilos e menos que $0,8 \%$ termófilos obrigatórios que cresceram com acetato. Foi observado que a $60{ }^{\circ} \mathrm{C}$ houve maior produção de nitrogênio amoniacal, diminuição do $\mathrm{pH}$ para aproximadamente 5,3 e diminuição de produção de metano. Dessa forma, o autor concluiu que o enriquecimento da cultura é crucial para digestão de resíduo sólido municipal a $60{ }^{\circ} \mathrm{C}$.

As espécies termofílicas são claramente diferentes das mesofílicas, o que significa que ocorre a mudança da população com o aumento da temperatura. Vários microrganismos metanogênicos desaparecem enquanto outros começam a aumentar sua população como as metanogênicas Methanobrevibacter arboriphilus e Methanobacterium thermoautotrophicum (VAN LIER et al., 1992).

Vazoller (1997) estudou a ecologia microbiana anaeróbia em um reator UASB termofílico alimentado com vinhaça. Dentre os resultados, a autora relatou que o inóculo utilizado (mistura de lodo de reator mesofílico e esterco bovino) foi apropriado para as condições de operação deste reator. Os microrganismos produtores de metano envolvidos na degradação anaeróbia da vinhaça eram semelhantes à Methanosarcina e à co-cultura formada por Methanobacterium sp e Desulfotomaculum sp, sendo esta última se tratava de uma bactéria redutora de sulfato que possuía função importante na degradação do ácido propiônico dentro do reator.

Van Lier (1993) sugeriu que a partida de processo anaeróbio termofílico inoculado com lodo mesofílico $\left(38^{\circ} \mathrm{C}\right)$ deve ser feita para $45^{\circ} \mathrm{C}$ e $65^{\circ} \mathrm{C}$. Com o salto de temperatura, a produção de metano decresce até níveis próximos a zero e há aumento da velocidade de decaimento celular dos microrganismos mesófilos. Nesse processo de partida, segundo estudos do autor, a metanogênese termofílica deve começar após 7 a 15 dias, dependendo do aumento de temperatura e das características do inóculo. 
Quanto maior o salto de temperatura maior será o tempo para recuperar a produção de metano, provavelmente devido à baixa quantidade de microrganismos termofílicos com capacidade de crescimento em temperatura mais amena que colonizam o lodo mesofílico. Segundo resultados do autor, maior atenção deve ser dada à degradação de proprionato, que é o ácido volátil mais difícil de ser degradado em condições termofílicas, pois um incremento rápido da carga orgânica implica o aumento da concentração desse ácido.

A seguir serão apresentados alguns estudos realizados com diferentes tipos de lodos anaeróbios e estratégias de desenvolvimento de lodo sob condições termofílicas em diferentes configurações de reatores (Tabela 3.4).

Tabela 3.4 - Principais características de inóculos usados na partida de reatores termofílicos de alguns trabalhos.

\begin{tabular}{|c|c|c|c|c|}
\hline Tipo inóculo & $\begin{array}{l}\text { Fonte de } \mathrm{C} \\
\text { na partida }\end{array}$ & $\begin{array}{l}\text { Estratégia } \\
\text { adaptação }\end{array}$ & $\begin{array}{l}\text { Duração } \\
\text { (d) }\end{array}$ & Referência \\
\hline Lodo $\mathrm{ETE}^{1}+\mathrm{UASB}$ & $\begin{array}{c}\text { Metanol } \\
30 \%\end{array}$ & $32 \rightarrow 55^{\circ} \mathrm{C}$ & 45 & $\begin{array}{r}\text { Balaguer } \text { et al. } \\
\text { (1991) }\end{array}$ \\
\hline UASB & $\begin{array}{l}\text { Acetato + } \\
\text { Sacarose }\end{array}$ & $55 \rightarrow 65^{\circ} \mathrm{C}$ & 60 & $\begin{array}{c}\text { Uemura \& } \\
\text { Harada (1993) }\end{array}$ \\
\hline $\begin{array}{l}75 \% \text { Lodo ETE + } \\
25 \% \text { estrume bovino }\end{array}$ & $\mathrm{RSU}^{2}$ & $\begin{array}{c}37 \rightarrow 55^{\circ} \mathrm{C} \\
\left(2 \mathrm{~g} \mathrm{NaHCO}_{3} / \mathrm{L}\right)\end{array}$ & 70 & $\begin{array}{r}\text { Griffin et al. } \\
\text { (1998) }\end{array}$ \\
\hline \multirow[t]{2}{*}{ Lodo ETE } & \multirow{2}{*}{$\begin{array}{l}\text { Esgoto } \\
\text { doméstico }\end{array}$} & $\begin{array}{c}38 \rightarrow 55^{\circ} \mathrm{C} \\
\left(\text { gradual a cada } 4{ }^{\circ} \mathrm{C} \text { ) }\right.\end{array}$ & 300 & \multirow{2}{*}{$\begin{array}{r}\text { Zábranská et } \\
\text { al. (2002) }\end{array}$} \\
\hline & & $38 \rightarrow 55^{\circ} \mathrm{C}$ & 210 & \\
\hline \multirow{2}{*}{$\begin{array}{l}\text { Lodo anaeróbio } \\
\text { (13 g SV/L) }\end{array}$} & \multirow{2}{*}{$\begin{array}{l}\text { Lodo de } \\
\text { ETE }\end{array}$} & $\begin{array}{c}37 \rightarrow 55^{\circ} \mathrm{C} \\
\left(\text { gradual a cada } 4^{\circ} \mathrm{C}\right)\end{array}$ & 70 & \multirow{2}{*}{$\begin{array}{r}\text { Bouskova et al. } \\
\text { (2005) }\end{array}$} \\
\hline & & $37 \rightarrow 55^{\circ} \mathrm{C}$ & 30 & \\
\hline $\begin{array}{l}\text { Lodo anaeróbio ETE } \\
+ \text { estrume bovino }\end{array}$ & $\begin{array}{l}\text { Vinhaça } \\
\text { cana }\end{array}$ & Direto a $55^{\circ} \mathrm{C}$ & 150 & $\begin{array}{r}\text { Souza } \text { et al. } \\
\text { (1992) }\end{array}$ \\
\hline
\end{tabular}

${ }^{\mathrm{I}}$ ETE: estação de tratamento de esgoto, ${ }^{2} \mathrm{RSU}$ : resíduos sólidos urbano.

Uemura \& Harada (1993) estudaram o efeito da temperatura a $55{ }^{\circ} \mathrm{C}$ e a $65{ }^{\circ} \mathrm{C}$ com a finaliade de avaliar o comportamento microbiano do lodo termofílico, com enfoque na associação sintrófica da bactéria oxidante de acetato com a arquéia produtora de metano hidrogenotrófica, pois, Zinder \& Koch (1984) ${ }^{6}$, citados pelos autores, relataram que esta associação deve ser maior em condições termofílicas. No

\footnotetext{
${ }^{6}$ ZINDER, S.H.; KOCH, M. (1984). Non-acetoclastic methanogenesis from acetate: acetate-oxidation by a thermophilic acetotrophic syntrophic coculture. Archives of Microbiology, 138, 263-272.
} 
trabalho os autores observaram formação de leito composto por grânulos de lodo e estabilidade do reator com cargas orgânicas aplicadas (expressas em carbono orgânico total COT) de $34 \mathrm{~kg} / \mathrm{m}^{3}$.d a $55^{\circ} \mathrm{C}$, e $16 \mathrm{~kg} / \mathrm{m}^{3}$.d a $65^{\circ} \mathrm{C}$.

Griffin et al. (1998) no estudo da dinâmica da população metanogênica durante a partida de um reator anaeróbio de bancada com mistura completa tratando resíduo sólido municipal e biossólidos, atingiram taxa de carregamento orgânico referente à massa de sólidos voláteis por volume de reator de $3,1 \mathrm{~kg} / \mathrm{m}^{3}$.d com tempo de retenção de 20 dias, em que o reator termofílico que produziu mais que $1,52 \mathrm{~m}^{3} / \mathrm{m}^{3}$.d de biogás com $59 \%$ de metano, remoção de $54 \%$ de sólidos voláteis e $58 \%$ de celulose.

Por outro lado, o reator mesofílico operado pelos autores, apresentou valores instáveis e altas concentrações de ácidos graxos voláteis especialmente propionato, difícil controle de $\mathrm{pH}$, produção de $0,96 \mathrm{~m}^{3} / \mathrm{m}^{3}$.d de biogás com $54 \%$ de metano e remoção de $53 \%$ de sólidos voláteis. Apesar de a estratégia de partida do reator termofílico ter sido agressiva em virtude do aumento brusco de temperatura direto a $55^{\circ} \mathrm{C}$ para um inoculo mesofílico, os autores consideram que ela foi bem sucedida pela maior estabilidade e eficiência que a apresentada pelo reator mesofílico.

Pérez et al. (1999) compararam várias relações entre o substrato e a quantidade de microrganismos $(\mathrm{S} / \mathrm{X})$ com a finalidade de avaliar como resposta a maior eficiência de tratamento da vinhaça em reator de leito fluidificado. Os autores encontraram maior eficiência de remoção de DQO de $80 \%$ com produção de metano de $9,0 \mathrm{~m}^{3} / \mathrm{m}^{3}$.d na relação $\mathrm{S} / \mathrm{X}$ de $0,55 \mathrm{~kg} \mathrm{DQO} / \mathrm{kg} \mathrm{SV}$ adicionado.d.

Como já relatado, o tratamento termofílico também pode ser utilizado para estabilizar lodos de estações de tratamentos de águas residuárias urbanas ou industriais, por serem resíduos que apresentam alta carga orgânica.

Nesse sentido, Zábranská et al. (2002) estudaram a estabilização de lodo de estações de tratamento de esgoto. Dois reatores foram operados, um para com aumento gradual de temperatura de $38{ }^{\circ} \mathrm{C}$ a $55^{\circ} \mathrm{C}$, outro com aumento brusco. A carga orgânica de projeto de $4,1 \mathrm{~kg} / \mathrm{m}^{3}$.d de sólidos voláteis por volume de reator por dia. Nesta carga, os autores observaram que o biogás do reator termofílico com aumento brusco apresentava menos de $30 \%$ de sulfeto de hidrogênio no biogás que o reator mesofílico. Além disso, foi observado que o biogás dos reatores mesofílicos apresentou dimeltilsulfeto $\left(34 \mu \mathrm{g} / \mathrm{m}^{3}\right)$, dimetildissulfeto $\left(388 \mu \mathrm{g} / \mathrm{m}^{3}\right)$ e metilpropildissulfeto (88 $\mu \mathrm{g} / \mathrm{m}^{3}$ ), que são compostos que emitem fortes odores. Em resumo, os autores concluíram que o reator termofílico produziu um lodo mais resistente, com menores 
problemas de escuma, menor teor de sulfeto, maior eficiência na remoção de patógenos e na remoção de outras substâncias causadoras de maus odores.

O processo termofílico também foi avaliado por Bouskova et al. (2005) quanto à adaptação de reatores mesofílicos à temperatura termofílica tratando lodo de estações de tratamento em um reator agitado de fluxo contínuo com tempo de detenção hidráulica de 20 dias e carga orgânica aplicada de sólidos voláteis totais por volume de reator de $1,38 \mathrm{~g} / \mathrm{L} . \mathrm{d}$. Certa instabilidade foi observada entre $42{ }^{\circ} \mathrm{C}$ e $47{ }^{\circ} \mathrm{C}$ no reator com aumento gradual, forte distúrbio na produção de biogás, teor de metano e concentração de ácidos voláteis, que pôde ser explicado pelos intervalos dos pontos ótimos de temperatura de microrganismos anaeróbios mesófilos e termófilos. O reator com aumento brusco apresentou logo após a mudança para $55^{\circ} \mathrm{C}$, um aumento de $37 \mathrm{mM}$ de acetato e $16 \mathrm{mM}$ de propionato, mas após 8 dias de operação houve redução total que persistiu até o final do experimento. Por fim, os autores consideraram que a estratégia de incremento direto para a temperatura de trabalho desejada foi a melhor forma de mudar a temperatura de operação de um reator anaeróbio mesofílico para termofílico, pois o tempo necessário para adaptação foi quase a metade daquele necessário para o reator que teve aumento gradual.

Em escala semi-industrial, Souza et al. (1992), alcançaram resultados eficientes na aplicação dos microrganismos termófilos metanogênicos na digestão anaeróbia da vinhaça. Os autores operaram, por 150 dias, um digestor anaeróbio de fluxo ascendente com manta de lodo de $75 \mathrm{~m}^{3}$. O reator foi inoculado com uma mistura de $100 \mathrm{~kg}$ de sólidos suspensos voláteis (SSV) provenientes de lodo de esgoto digerido anaerobiamente em condições mesofílicas e $100 \mathrm{~kg}$ de SSV de estrume bovino e a temperatura foi de $56 \pm 2{ }^{\circ} \mathrm{C}$. Com $30 \mathrm{~kg} \mathrm{DQO} / \mathrm{m}^{3}$.d o reator alcançou remoção estável de DQO de $72 \%$ e de sulfato de $98 \%$. Nesta etapa, o lodo granular apresentava concentração de sólidos suspensos voláteis de $20 \mathrm{~kg} / \mathrm{m}^{3}$.

Posteriormente, Souza et al. (1993) ${ }^{7}$ apud Vazoller (1995) apresentaram resultados de cinco anos de operação de um reator UASB de $75 \mathrm{~m}^{3}$, mantido à temperatura em torno de $55^{\circ} \mathrm{C}$, reafirmando a estabilidade e eficiência do processo com cargas de aproximadamente $30 \mathrm{kgDQO} / \mathrm{m}^{3}$.d. O lodo termófilo apresentou boa

\footnotetext{
7 Souza, M.E., Fuzaro, G., Furco, A.M. (1993). Biodigestão termofílica da vinhaça. In: Anais do Congresso Nacional da Sociedade dos Técnicos Açucareiros e Alcooleiros do Brasil, 5. Águas de São Pedro, São Paulo, Brasil, 1-21.
} 
decantabilidade em função da granulação bacteriana alcançada após 210 dias de funcionamento, após o período da entressafra da cana.

Vazoller (1997) examinou os aspectos microbiológicos do lodo desse reator e, verificou que a granulação com baixa carga orgânica como DQO por volume de reator por dia em aproximadamente 4,5 g/L.d ocorreu após 6 meses de operação, com grânulos escuros e densos de 2 a $3 \mathrm{~mm}$ de diâmetro contendo 4,8 g SSV/L, em que foram observados microscopicamente formas com abundante fluorescência como Methanosarcina e bacilos. Foram identificadas e isoladas co-culturas de arquéias metanogênicas acetoclásticas, Methanobacterium e Methanosarcina, indicando a possibilidade de que o acetato no reator foi convertido a metano via hidrogênio e dióxido de carbono como intermediários em meio enriquecido.

Torna-se de fundamental importância o desenvolvimento de digestores anaeróbios com elevado desempenho, que é conseqüência da organização eficiente dos microrganismos anaeróbios pela formação de nichos ecológicos como os lodos granulados e biofilmes, ficando retidos dentro do sistema (VAZOLLER, 1995). Diversos estudos tiveram como objetivo avaliar diferentes configurações de reatores com a finalidade de aperfeiçoar o tratamento anaeróbio de vinhaça.

\subsection{Aplicações de processos anaeróbios de tratamento de vinhaça}

No Brasil, o aproveitamento da vinhaça in natura na agricultura como fertilizante é prática comum, mas deve ser utilizada quando a matéria orgânica estiver estabilizada, pois essa água residual possui uma ação redutora extremamente alta.

Diante desse contexto, o processo anaeróbio se constitui em uma tecnologia adequada para a estabilização das altas concentrações de matéria orgânica presente na vinhaça, possibilitando produzir dois produtos finais de valor econômico, o gás metano como fonte de energia e o efluente que pode ser usado com maior segurança como fertilizante de solos devido à redução de matéria orgânica pelo processo anaeróbio, mas ainda com concentrações consideráveis de nutrientes (MADEJÓN et al., 2001).

Vários autores avaliaram o reator UASB para tratamento anaeróbio termofílico da vinhaça por apresentar melhor desempenho (WIEGANT et al., 1986, SOUZA et al, 1992, VLISSIDIS \& ZOUBOULIS, 1993, DRIESSEN et al., 1994 e HARADA et al., 1996). Mas, outras configurações de reatores já foram estudadas como alternativas para tratamento da vinhaça (BALAGUER et al., 1997, FERNANDEZ et al., 2001, TELH, 
2001 e RUIZ et al., 2001). Alguns dos estudos mais significativos sobre o tratamento anaeróbio de vinhaça são apresentados na Tabela 3.5 com relação às taxas máximas obtidas de carregamento orgânico. Posteriormente, serão discutidos pontualmente alguns detalhes interessantes de cada estudo.

Para atingir o desempenho apresentado na Tabela 3.5, Lalov et al. (2001) utilizaram um consórcio metanogênico imobilizado em grânulos porosos de acrilonitrilo e acrilamida que são polímeros sintéticos de 1,5 mm de diâmetro com agitação.

Pérez et al. (1999) trataram vinhaça de destilaria de vinho em condições termofílicas em reator anaeróbio de leito fluidificado regime semicontínuo com expansão do leito de $25 \%$, o qual era composto por partículas de vidro (open-pore sintered glass bed). Nos experimentos, os autores ressaltaram que foi necessário adicionar hidróxido de sódio na quantidade necessária para manter $\mathrm{pH}$ neutro no interior do reator.

Harada et al. (1996) adicionaram meio de nutrientes e de elementos traço de acordo com Wiegant \& Lettinga (1985) com suplementação de bicarbonato de sódio como tampão na concentração de $5 \mathrm{~g} / \mathrm{L}$ para manter o $\mathrm{pH}$ ao redor de 7,3 ao longo de toda fase experimental.

Fdz-Polanco et al. (2001) utilizaram reator anaeróbio de leito fluidificado internamente, com volume de 1,5 litros, preenchido com carvão ativado granulado, com partículas de diâmetro médio entre 0,42 e $0,85 \mathrm{~mm}$ com expansão de leito de $30 \%$. O inóculo usado foi lodo anaeróbio de um reator de contato de indústria de levedura e adição de diferentes doses de sulfato e amônio. $\mathrm{O}$ pH dentro do reator variou de 7,8 e 8,3 e o potencial oxi-redução entre -425 e $-435 \mathrm{mV}$. 
Tabela 3.5 - Dados experimentais obtidos em reatores anaeróbios para tratamento da vinhaça de diversas origens.

\begin{tabular}{|c|c|c|c|c|c|c|c|c|c|}
\hline Temperatura & $\begin{array}{l}\text { Configuração } \\
\text { (volume útil) }\end{array}$ & $\begin{array}{l}\text { Tempo } \\
\text { operação } \\
\text { (d) }\end{array}$ & $\begin{array}{l}\text { Origem } \\
\text { vinhaça }\end{array}$ & $\begin{array}{l}\text { DQO } \\
\text { afluente } \\
(\mathrm{g} / \mathrm{L}) \\
\end{array}$ & $\begin{array}{c}\mathrm{COV}_{\text {max }}{ }^{1} \\
\left({\mathrm{~kg} . \mathrm{m}^{-3}}^{-3} \cdot \mathrm{d}^{-}\right. \\
\left.\mathbf{1}^{-}\right)\end{array}$ & $\begin{array}{c}\text { TDH }^{2} \\
\text { (d) }\end{array}$ & $\begin{array}{c}\mathcal{E}_{\mathrm{DQO}}{ }^{3} \\
(\%)\end{array}$ & $\begin{array}{c}\text { Rendimento } \\
\mathbf{C H}_{4} \\
\left(\mathbf{m}^{3} \cdot \mathbf{m}^{-3} \cdot \mathbf{d}^{-1}\right) \\
\end{array}$ & Referência \\
\hline \multirow{7}{*}{$\begin{array}{l}\text { Mesofílico } \\
\left(32-37^{\circ} \mathrm{C}\right)\end{array}$} & Filme fixo $(0,8 \mathrm{~L})$ & 90 & Vinícola & 61 & 20 & 3 & 37 & 3,8 & Lalov et al. (2001) \\
\hline & $\begin{array}{l}\text { Fluidificado com pedra } \\
\text { pome }(0,63 \mathrm{~L})\end{array}$ & 66 & Vinícola & 18 & 36 & 0,5 & 76 & 8,2 & Balaguer et al. (1997) \\
\hline & $\begin{array}{l}\text { Fluidificado com carvão } \\
\text { granular ativado }(1,5 \mathrm{~L})\end{array}$ & 250 & $\begin{array}{l}\text { Açúcar } \\
\text { beterraba }\end{array}$ & 1,7 & 5,3 & 3 & 87 & 2,3 & Fdz-Polanco et al. (2001) \\
\hline & $\begin{array}{l}\text { Fluidificado com carvão } \\
\text { ativado }(0,75 \mathrm{~L})\end{array}$ & 120 & $\begin{array}{c}\text { Álcool } \\
\text { cana }\end{array}$ & 33 & 10,0 & 0,3 & 76 & 0,8 & \multirow{2}{*}{ Fernández et al. (2001) } \\
\hline & $\begin{array}{l}\text { Fluidificado com zeolita } \\
(1,0 \mathrm{~L})\end{array}$ & 120 & $\begin{array}{l}\text { Álcool } \\
\text { cana }\end{array}$ & 66 & 10,0 & 0,6 & 80 & 1,2 & \\
\hline & UASB $(0,5 \mathrm{~L})$ & n.d. & Vinícola & 31 & 9,1 & 3,4 & 90 & 0,72 & $\begin{array}{r}\text { Moosbrugger et al } \\
\text { (1993) }\end{array}$ \\
\hline & Batelada seqüencial (5L) & 147 & $\begin{array}{c}\text { Acúcar } \\
\text { cana }\end{array}$ & 16 & 2,4 & $6,6^{*}$ & 96 & n.d. & Ruiz (2002) \\
\hline \multirow{7}{*}{$\begin{array}{l}\text { Termofílico } \\
\left(53-55^{\circ} \mathrm{C}\right)\end{array}$} & $\operatorname{UASB}\left(2000 \mathrm{~m}^{3}\right)$ & 200 & $\begin{array}{l}\text { Açúcar } \\
\text { beterraba }\end{array}$ & 60 & 6,0 & 10 & 86 & 1,9 & $\begin{array}{r}\text { Vlissidis \& Zouboulis } \\
\text { (1993) }\end{array}$ \\
\hline & UASB $(5,75 \mathrm{~L})$ & 120 & $\begin{array}{c}\text { Álcool } \\
\text { beterraba }\end{array}$ & 15,4 & 86,4 & 0,2 & 60 & 26 & Wiegant et al.(1986) \\
\hline & Fluidificado (n.d.) & 90 & Vinícola & 15,0 & 40,5 & 2,55 & 82 & 7,5 & Pérez et al. (1999) \\
\hline & UASB (140 L) & 430 & $\begin{array}{l}\text { Álcool } \\
\text { cana }\end{array}$ & 10 & 24 & 0,42 & 45 & n.d. & Harada et al. (1996) \\
\hline & UASB $\left(70 \mathrm{~m}^{3}\right)$ & 280 & $\begin{array}{l}\text { Álcool } \\
\text { cana }\end{array}$ & 31,5 & 25 & 2 & 72 & 10 & Souza et al (1992) \\
\hline & $\operatorname{RAHLF}^{4}(2 \mathrm{~L})$ & 90 & $\begin{array}{l}\text { Álcool } \\
\text { cana }\end{array}$ & 10 & 9,1 & 1,1 & 70 & n.d. & Telh (2001) \\
\hline & UASB $(10 \mathrm{~L})$ & 200 & $\begin{array}{l}\text { Álcool } \\
\text { cana }\end{array}$ & $5,0-6,5$ & $5,0-6,5$ & 1 & 45 & n.d. & Viana (2006) \\
\hline
\end{tabular}

n.d.: dado não disponível; *Tempo de ciclo de cada batelada. ${ }^{1}$ COVmáx: carga orgânica volumétrica máxima; ${ }^{2}$ TDH: tempo de detenção hidráulica; ${ }^{3} \varepsilon$ DQo: eficiência de remoção ${ }^{4}$ RAHLF: reator anaeróbio horizontal de leito fixo 
Embora, o reator do tipo leito fluidificado tenha mostrado boa eficiência no tratamento, tanto em temperatura mesofílica como termofílica, conforme dados apresentados na Tabela 3.5, o sistema apresenta, como aspecto negativo operacional, que é intrínseco a esta configuração, o gasto de energia para expansão do leito em aproximadamente $30 \%$ do volume total do reator sendo, portanto, susceptível a quedas de energia elétrica. Já o reator UASB apresentou menor eficiência na digestão termofílica $\left(55^{\circ} \mathrm{C}\right)$ que na mesofílica $\left(30{ }^{\circ} \mathrm{C}\right)$ (Tabela 3.3), mas, em compensação, maior produção de metano, em menor tempo e com carga orgânica volumétrica (COV) três vezes maior (WILKIE et al., 2000).

Ruiz (2002), conforme apresentado na Tabela 3.5, trataram com sucesso vinhaça de cana-de-açúcar em reator batelada seqüencial contendo biomassa suspensa, atingindo uma COV de 2,4 g/L.d, com tempo de batelada de 6,6 dias e carga específica de 0,67 g DQO/g SSV.d e relação S/X média de 0,29 g DQO/g SSV. Obteve-se cerca de $96 \%$ de remoção de DQO solúvel. Nessas condições, a quantidade total de metano gerado em um ciclo de tratamento e rendimento de metano foram de 2,2 $\mathrm{L}$ de $\mathrm{CH}_{4}$ e $0,37 \mathrm{~L}_{\text {de }} \mathrm{CH}_{4}$ por g de DQO removida, respectivamente.

Em trabalho anterior, Ruiz et al. (2001) trataram vinhaça proveniente do processamento da beterraba no mesmo reator a $35{ }^{\circ} \mathrm{C}$ atingindo uma $\mathrm{COV}$ de $8,6 \mathrm{~g} / \mathrm{L} . \mathrm{d} \mathrm{e}$ tempo de ciclo de 2,2 dias com carga específica de 0,96 g DQO/g SSV.d. Nesse trabalho, os autores obtiveram remoção de $98 \%$ da DQO solúvel. No entanto, esta boa eficiência foi alcançada após um período de 90 dias de adaptação ao resíduo com baixa concentração e 60 dias de operação nas condições mencionadas a $35{ }^{\circ} \mathrm{C}$. Os autores investigaram as cinéticas de remoção de DQO e ácidos orgânicos voláteis para vinhaça e, para compostos simples como etanol, o maior componente da DQO da vinhaça, e acetato, sal oriundo do ácido acético, principal ácido orgânico volátil produzido no tratamento anaeróbio da vinhaça. A comparação dos perfis obtidos com os três substratos mostrou que a acidificação da matéria orgânica e a formação de metano a partir dos ácidos orgânicos voláteis seguiram reação de ordem zero nas condições operacionais estudadas.

Apesar da vantagem de flexibilidade operacional do reator batelada seqüencial, Massé \& Massé (2001) observaram significativa perda de lodo do reator operado em bateladas seqüenciais e sugeriram que a eficiência do tratamento nesta configuração de reator poderia ser maior se a perda de lodo anaeróbio fosse controlada. Para a manutenção da estabilidade operacional e de uma elevada concentração de biomassa 
ativa no interior deste reator, por tempo prolongado, foi proposta a utilização de cubos de espuma de poliuretano por Zaiat et al. (2001), por ser um suporte inerte e por ser verificado que a biomassa adere com firmeza a este material (VARESCHE et al., 1997).

Com algumas medidas para melhorar o desempenho, é possível que o reator batelada seqüencial possa promover eficiências similares no tratamento da vinhaça proveniente do processamento da cana-de-açúcar quanto às apresentadas por Ruiz et al. (2001), em menor tempo de ciclo, utilizando-se, por exemplo, meio suporte (ZAIAT et al., 2001) e operá-lo em temperatura termofílica (SOUZA et al., 1992 e PÉREZ et al., 1999), constituindo-se em uma configuração de reator interessante para equacionar problemas advindos do período de entressafra.

\subsection{Vantagens e inconvenientes do tratamento anaeróbio termofílico}

Como principais vantagens da digestão anaeróbia termofílica acima de $50{ }^{\circ} \mathrm{C}$ estão a possibilidade da utilização de cargas orgânicas maiores que em condições mesofílicas e a destruição de patógenos (BITTON, 1994).

Van Lier (1993) cita outros aspectos positivos do tratamento termofílico como:

(i) Em sistema de mistura completa, foi verificado que a digestão anaeróbia termofílica apresentou velocidade de crescimento de microrganismos importantes de 2 a 3 vezes superiores que a $30{ }^{\circ} \mathrm{C}$, o que implica em maiores atividades específicas e reatores menores e/ou curtos tempos de retenção hidráulica ou tempo de ciclo;

(ii) Maior atividade específica de conversão do substrato em reatores de alta velocidade com elevado tempo de retenção de biomassa, que pode ser atribuída às maiores necessidades energéticas para a manutenção dos microrganismos envolvidos;

(iii) Elevado grau de eliminação de patógenos, geralmente mesófilos, o que é de grande importância quando o lodo digerido ou efluente é empregado como fertilizante;

(iv) Melhor capacidade de secagem ou deságüe do lodo anaeróbio gerado;

(v) Baixa viscosidade do líquido que aumenta o grau de mistura e a sedimentabilidade de partículas formadas.

Como inconvenientes, o autor cita a necessidade de elevados requerimentos energéticos para o aquecimento do reator, caso o efluente a ser tratado não seja gerado em elevada temperatura, como é o caso dos efluentes de destilarias e de indústrias de papel e celulose. O incremento dos níveis de ácidos graxos voláteis e o possível 
aumento de toxicidade de compostos como $\mathrm{NH}_{3}$ podem ser outros problemas advindos do processo termofílico.

Oropeza et al. (2001) observaram que a digestão anaeróbia termofílica apresentou resultados satisfatórios comparados com a mesofilica quanto à remoção de organismos indicadores de contaminações fecais e parasitas como coliformes fecais e ovos de helmintos de lodo de tratamento biológico de esgoto municipal. No caso, para que um biossólido, lodo estabilizado, pudesse ser aproveitado como condicionador de solo, deveria atender às recomendações da Organização Mundial da Saúde (World Health Organization), da Agência de Proteção Ambiental dos Estados Unidos (Environmental Protection Agency - EPA, 1996) e de regulamentos locais, particularmente regulamentos mexicanos, apresentando o limite referente a ovos de helmintos em forma larval $\left(\mathrm{OH}_{\text {larval }}\right)$ de 0,25 a cada grama de sólidos totais (ST), e de coliformes fecais < 1000 de número mais provável (NMP) por cada grama de sólidos totais. Os resultados encontrados pelos autores, em 20 dias de experimento, mostram que o lodo biológico estabilizado em reator termofílico apresentou $0,28 \mathrm{OH}_{\text {larval }} / \mathrm{g} \mathrm{ST}$ e < 1000 NMP de coliformes fecais, sendo que o lodo do reator mesofílico apresentou 2,6 $\mathrm{OH}$ larval/g ST e > $15000 \mathrm{NMP/g} \mathrm{ST}$. Assim, a digestão anaeróbia termofilica pode ser uma tecnologia adequada para a remoção de patógenos de biossólidos com finalidade de uso na agricultura.

Zábranská et al. (2002) estudaram a estabilização de lodo de estações de tratamento de esgoto. Segundo eles, os processos termofílicos têm maior eficiência na degradação de matéria orgânica em comparação com processos mesofílicos, porque pode ser obtido maior produção de biogás e menor teor de sólidos voláteis no lodo digerido que representa menos quantidade de lodo estabilizado com melhores propriedades de desagüe.

\subsection{Considerações Finais}

A partir da revisão de literatura sobre diversos estudos a respeito do tratamento anaeróbio da vinhaça, vislumbrou-se neste trabalho, a possibilidade de aplicação do tratamento anaeróbio da vinhaça gerada durante o processamento de álcool a partir da cana-de-açúcar, sob condição termofílica em comparação com mesofílica em reator anaeróbio operado em batelada seqüencial contendo biomassa imobilizada em cubos de espuma de poliuretano, já que esta configuração tem sido utilizada com êxito no 
tratamento de diversos efluentes que apresentam considerável concentração de matéria orgânica como, por exemplo, tratamento de dejetos de suínos (NG, 1989), águas residuárias de soro de queijo (RATUSZNEI et al., 2003), abadetouros (MASSÉ \& MASSE, 2001), chorume (HOLLOPETER \& DAGUE, 1994) e, dentre outros tipos de resíduos, a vinhaça (RUIZ, 2002).

As indústrias sucroalcooleiras de cana-de-açúcar trabalham sazonalmente durante a época da safra da cultura que, no Estado de São Paulo, compreende o período de março a dezembro. Dessa forma, o sistema de tratamento da vinhaça proposto nesse trabalho seria contínuo composto por vários reatores anaeróbios em paralelo, operados em bateladas seqüenciais.

Outro ponto a ser considerado, é que os processos anaeróbios são amplamente utilizados em condições de temperatura mesofílicas, mas o uso da tecnologia anaeróbia sob condições termofílicas no tratamento de águas residuárias ainda não está totalmente esclarecido em alguns aspectos, o que dificulta o aprofundamento no tema.

De acordo com a revisão bibliográfica apresentada, pode-se verificar que há alguns trabalhos que indicam que o processo termofílico é mais eficiente e outros que apontam para a instabilidade do processo.

É importante destacar que não foram encontrados estudos sobre reatores anaeróbios operados em bateladas seqüenciais contendo biomassa imobilizada para tratamento desse tipo de água residuária, com exceção dos trabalhos de Ruiz et al. (2001) que trabalhou com tratamento de vinhaça do processamento da beterraba em ASBR sem imobilização da biomassa e em condições mesofílicas e Ruiz (2002) que tratou vinhaça de cana-de-açúcar na mesma configuração de reator usada no trabalho anterior.

Portanto, pouco se conhece sobre o potencial de uso dessa configuração de reator para esse tipo de água residuária, assim como não está definido qual condição de temperatura permite a obtenção do melhor desempenho e maior estabilidade operacional. 


\section{Material e métodos}

"Grandes realizações não são feitas por impulso, mas por uma soma de pequenas realizações." Vincent van Gogh

Os procedimentos experimentais adotados em cada fase experimental do trabalho estão descritos neste capítulo, bem como toda metodologia empregada. Serão abordadas as metodologias utilizadas para caracterização dos lotes de vinhaça utilizados, a composição da água residuária, a configuração do reator, o inóculo utilizado, os procedimentos para a adaptação do inóculo à vinhaça e às condições termofílicas. Serão descritos, também, os métodos para avaliar o desempenho do reator ressaltando-se a eficiência de remoção de matéria orgânica, para determinação dos parâmetros cinéticos e para o acompanhamento da colonização microbiológica ao longo do período experimental.

Vale a pena destacar que o trabalho foi composto de três partes experimentais desenvolvidas em momentos cronologicamente distintos. Inicialmente, no ano de 2004, foi operado por 14 meses no Laboratório de Processos Biológicos do Departamento de Hidráulica e Saneamento da Escola de Engenharia de São Carlos da Universidade de São Carlos - SP/Brasil (LPB/SHS/EESC-USP), um ASBBR em escala de bancada de 7,2 L sob condição termofílica (cerca de $55^{\circ} \mathrm{C}$ ) tratando vinhaça oriunda do processamento de álcool de cana-de-açúcar.

A segunda parte foi desenvolvida no Laboratório de Águas do Departamento da Engenharia Química da Universidade de Valladolid - Espanha, no período compreendido de maio a outubro de 2005, em que foram realizados ensaios complementares com um reator de mesma configuração, porém de menor volume $(0,8$ L) no tratamento termofílico de água residuária sintética semelhante à vinhaça do processamento de beterraba para produção de açúcar. Concomitantemente, neste mesmo local, foram realizados ensaios paralelos em frascos-reatores, objetivando obter a 
biodegradabilidade anaeróbia pelo lodo granular utilizado como inóculo tanto em condições mesofílicas como termofílicas.

Os resultados destes últimos ensaios em frascos-reatores, motivaram a terceira fase do projeto que foi realizada no LPB/SHS da EESC (Brasil), em que a vinhaça do processamento da cana-de-açúcar foi submetida ao tratamento anaeróbio no ASBBR (de 7,2 L) em condições mesofílicas (aproximadamente $35^{\circ} \mathrm{C}$ ) por 4 meses, de dezembro de 2005 a março de 2006, a fim de se obterem resultados que permitissem comparações entre os tratamentos sob as condições termofílica e o mesofílica de vinhaça de cana.

O desenvolvimento experimental não será apresentado em ordem cronológica, mas sim em função do tipo de água residuária avaliada. Primeiramente, serão descritos os experimentos que envolveram o tratamento de vinhaça de cana-de-açúcar em ASBBR sob condições termofílica e mesofílica que foram feitos no Brasil (correspondentes a primeira e terceira partes em ordem cronológica) e, por fim, serão relatados os ensaios complementares realizados no Departamento de Engenharia Química da Universidade de Valladolid (Espanha) com tratamento de vinhaça semelhante àquela originada no processamento da beterraba em ASBBR e em frascosreatores.

Todas as etapas da pesquisa e os procedimentos experimentais adotados, tanto para as condições termofílicas, como para as condições mesofílicas, no tratamento de vinhaça de cana-de-açúcar, podem ser visualizadas na Figura 4.1. Na Figura 4.2 está apresentado o fluxograma experimental aplicado nos ensaios complementares com água residuária sintética semelhante a vinhaça de beterraba. 
OPERAÇÃO DO SISTEMA

Regime descontínuo: batelada

\begin{tabular}{|c|c|c|c|}
\hline \multicolumn{2}{|c|}{ CONDIÇÕES TERMOFÍLICAS - 55 oC } & \multicolumn{2}{|c|}{ CONDIÇÕES MESOFÍLICAS - 35 oC } \\
\hline $\begin{array}{l}\text { Adaptação } \\
50 \text { dias }\end{array}$ & $\begin{array}{c}\text { Fase IV - } 3,3 \mathrm{~g} \text { DQO/L.d (10 gDQO/L) } \\
3 \text { ciclos de } 1 \text { dia } \\
\text { Perfil prévio de } 4 \text { dias } \\
2 \text { ciclos de } 3 \text { dias }\end{array}$ & $\begin{array}{l}\text { Adaptação } \\
16 \text { dias }\end{array}$ & $\begin{array}{r}\text { Fase IV - } 1 \\
24 \text { ciclo }\end{array}$ \\
\hline $\begin{array}{c}\text { Fase I - 1,0 gDQO/L.d } \\
8 \text { ciclos de } 1 \text { dia }\end{array}$ & $\begin{array}{c}\text { Fase V - 3,3 gDQO/L.d (20,0 gDQO/L) } \\
3 \text { ciclos de } 1 \text { dia } \\
\text { Perfil prévio de } 6 \text { dias } \\
17 \text { ciclos de } 6 \text { dias }\end{array}$ & $\begin{array}{c}\text { Fase I - 2,5 gDQO/L.d } \\
25 \text { ciclos de } 1 \text { dia }\end{array}$ & $\begin{array}{r}\text { Fase } \mathbf{V}-20 \\
6 \text { ciclos }\end{array}$ \\
\hline $\begin{array}{c}\text { Fase II - 2,5 gDQO/L.d } \\
22 \text { ciclos de } 1 \text { dia }\end{array}$ & $\begin{array}{c}\text { Fase VI - 3,3 gDQO/L.d (5 - } 15 \text { gDQO/L) } \\
\text { Recuperação do sistema } \\
\text { COV de 3,3 a 6,6 gDQO/L.d } \\
\text { Tempo ciclo variável }\end{array}$ & $\begin{array}{l}\text { Fase II - } \mathbf{5 , 0} \text { gDQO/L.d } \\
15 \text { ciclos de } 1 \text { dia }\end{array}$ & $\begin{array}{r}\text { Fase } \mathbf{V I}-3 \\
5 \text { ciclos } \\
\text { A }\end{array}$ \\
\hline $\begin{array}{l}\text { Fase III - } 3,3 \text { gDQO/L.d ( } 5 \mathrm{~g} / \mathrm{L} . \mathrm{d}) \\
3 \text { ciclos de } 1 \text { dia } \\
\text { Perfil prévio de } 3 \text { dias } \\
19 \text { ciclos de } 1,5 \text { dia }\end{array}$ & $\begin{array}{c}\text { Fase VII - } 5,0 \text { gDQO/L.d (10 gDQO/L) } \\
3 \text { ciclos de } 1 \text { dia } \\
\text { Perfil prévio de } 2 \text { dias } \\
19 \text { ciclos de } 2 \text { dias }\end{array}$ & $\begin{array}{c}\text { Fase III - 7,5 gDQO/L.d } \\
12 \text { ciclos de } 1 \text { dia }\end{array}$ & \\
\hline \multicolumn{2}{|c|}{$\begin{array}{c}\text { MONITORAMENTO => } \\
\text { ESTABILIDADE DINÂMICA APARENTE => } \\
\text { PERFIS TEMPORAIS - parâmetros cinéticos } \\
\text { (DQO, AOV, produção e composição biogás, fenol e pH) }\end{array}$} & \multicolumn{2}{|c|}{$\begin{array}{c}\text { MONITORAMENTO => } \\
\text { ESTABILIDADE DINÂMICA APARENTE => } \\
\text { PERFIS TEMPORAIS - parâmetros cinéticos } \\
\text { (DQO, AOV, produção e composição biogás, fenol e pH) }\end{array}$} \\
\hline
\end{tabular}

Figura 4.1 - Fluxograma do procedimento experimental em ASBBR com vinhaça de cana-de-açúcar realizado no Laboratório de Processos Biológicos da Escola de Engenharia de São Carlos da Universidade de São Paulo. 


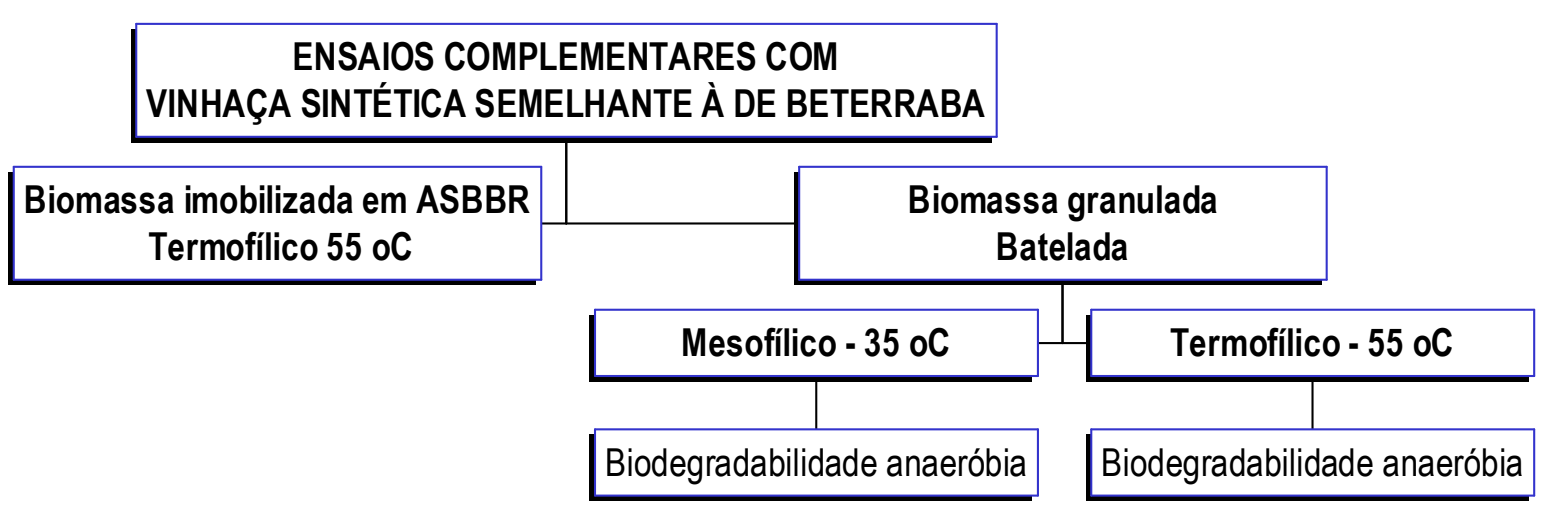

Figura 4.2 - Fluxograma experimental dos ensaios complementares realizados no Departamento de Engenharia Química da Universidade de Valladolid (Espanha) com água residuária semelhante à vinhaça de beterraba.

A seguir, são descritos os experimentos, os materiais e os métodos utilizados no desenvolvimento deste projeto.

\section{1 Água residuária}

A água residuária utilizada como afluente do ASBBR foi a vinhaça in natura, obtida após as colunas de destilação do mosto para separação do álcool e vinhaça, coletada nos canais de saída da Usina da Serra, em Ibaté/SP (S 21 57'18" latitude e W 47 $59^{\prime} 45^{\prime \prime}$ longitude), conforme ilustrado na Figura 4.3. Três lotes de vinhaça foram coletados e utilizados durante toda fase experimental. As coletas foram feitas durante a safra de cana-de-açúcar, entre abril e novembro, nas datas maio/2004, setembro/2004 e setembro/2005. A quantidade de vinhaça coletada em cada lote, cerca de $300 \mathrm{~L}$, foi armazenada em geladeira (a aproximadamente $4{ }^{\circ} \mathrm{C}$ ).

Algumas análises físico-químicas relativas às características principais da vinhaça foram feitas em cada lote coletado: $\mathrm{pH}$, alcalinidade a bicarbonato $(\mathrm{AB}) \mathrm{e}$ acidez volátil total (AVT), DQO, sólidos totais (ST), voláteis (SVT) e fixos (SFT), nitrogênio, fósforo, potássio, sulfato, cor e condutividade. A caracterização dos lotes de vinhaça segundo os parâmetros citados está apresentada na Tabela 4.1. As análises efetuadas seguiram procedimentos analíticos conforme APHA (1995), exceto a alcalinidade e a acidez volátil, que foram efetuadas de acordo com Dilallo \& Albertson (1961). 
A amostra foi composta de duas porções coletadas uma no início e outra no fim da coleta para representar o lote coletado.

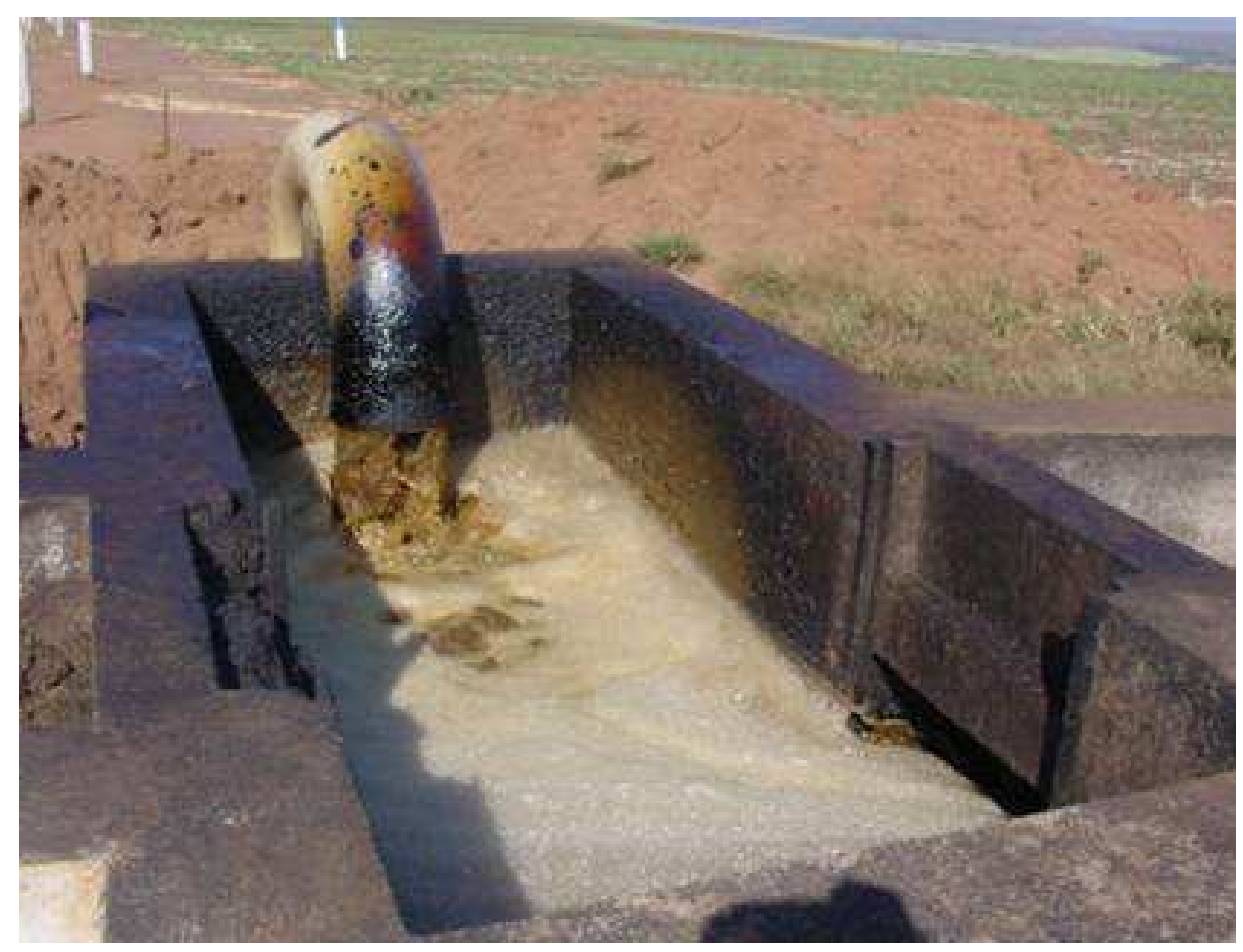

Figura 4.3 - Local de coleta de vinhaça - canal de saída da água residuária da Usina da Serra, em Ibaté/SP.

Para ser utilizada como afluente do reator, a vinhaça foi diluída com água de abastecimento até atingir a concentração desejada e foi suplementada com solução de minerais e com bicarbonato de sódio. 
Tabela 4.1 - Parâmetros físico-químicos de três diferentes lotes de vinhaça de cana-deaçúcar coletados em maio e setembro de 2004 e em setembro de 2005 usados como afluente nos experimentos (médias de duplicatas).

\begin{tabular}{lccc}
\hline & Maio/04 & Setembro/04 & Setembro/05 \\
\hline $\mathrm{pH}$ & 4,8 & 4,4 & 4,6 \\
Alcalinidade Total (mg CaCO $3 / \mathrm{L})$ & 1304 & 202 & 692 \\
Acidez Volátil Total (mg HAc/L) & 5900 & 2960 & 5296 \\
DQO (g/L) & 52 & 59 & 42 \\
Sólidos Totais (g/L) & 35,4 & 37,1 & 38,5 \\
$\quad$ Voláteis Totais (g/L) & 22,5 & 27,0 & 25,6 \\
$\quad$ Fixos Totais (g/L) & 12,5 & 10,2 & 12,9 \\
N-Total Kjeldahl (mg/L) & 587 & 6000 & 743 \\
P-Total (mg/L) & 55 & 44,1 & 73,9 \\
K-Total (mg/L) & 12500 & 1682 & 4309 \\
SO ${ }^{-2}$ (mg/L) & 1680 & 1920 & 1645 \\
Cor aparente (uCoPt) & 16140 & 39000 & n.d. \\
Condutividade (mS/cm) & 10,24 & 7,4 & 13,5 \\
\hline
\end{tabular}

n.d. - não determinado.

A Tabela 4.2 apresenta a composição da solução de nutrientes adicionada ao substrato, conforme proposto por Del Nery (1987).

Tabela 4.2 - Composição da solução de nutrientes para processos anaeróbios.

\begin{tabular}{lcc}
\hline & Composto & Concentração (mg/L) \\
\hline DQO & & 1000 \\
Sulfato de níquel & $\left(\mathrm{NiSO}_{4} \cdot 6 \mathrm{H}_{2} \mathrm{O}\right)$ & 0,5 \\
Sulfato ferroso & $\left(\mathrm{FeSO}_{4} \cdot 7 \mathrm{H}_{2} \mathrm{O}\right)$ & 2,5 \\
Cloreto férrico & $\left(\mathrm{FeCl}_{3} \cdot 6 \mathrm{H}_{2} \mathrm{O}\right)$ & 0,25 \\
Cloreto de cálcio & $\left(\mathrm{CaCl}_{2} \cdot 6 \mathrm{H}_{2} \mathrm{O}\right)$ & 23,5 \\
Cloreto de cobalto & $\left(\mathrm{CoCl}_{2} \cdot 6 \mathrm{H}_{2} \mathrm{O}\right)$ & 0,066 \\
Dióxido de selênio & $\left(\mathrm{SeO}_{2}\right)$ & 0,035 \\
Fosfato de sódio dibásico & $\left(\mathrm{Na}_{2} \mathrm{HPO}_{4} \cdot \mathrm{H}_{2} \mathrm{O}\right)$ & 15 \\
\hline
\end{tabular}

Fonte: Del Nery (1987). 
A composição da solução de nutrientes foi proporcional a 1000 mg de DQO, que neste caso, foi adicionado vinhaça para atingir este patamar.

A quantidade de bicarbonato de sódio adicionada ao afluente foi calculada em função da relação $\mathrm{HCO}_{3}{ }^{-} / \mathrm{DQO}$ que variou entre as fases de 0,2 a 1,2 de acordo com a resposta do reator indicada pelos valores de alcalinidade a bicarbonato e acidez volátil total que foram medidos no efluente. Sendo que a intenção era reduzir a quantidade de bicarbonato ao sistema de uma fase para outra. A relação de $\mathrm{HCO}_{3}{ }^{-} / \mathrm{DQO}$ do afluente mantida em cada fase experimental da operação do ASBBR termofílico está apresentada na Tabela 4.5 e da operação mesofílica do mesmo reator está na Tabela 4.7.

A quantidade de nitrogênio disponível na vinhaça foi suficiente para suprir a necessidade dos microrganismos anaeróbios do processo, não tendo sido necessário o fornecimento adicional desse nutriente.

\subsection{Configuração do reator}

O experimento foi montado nas dependências do Laboratório de Processos Biológicos do Departamento de Hidráulica e Saneamento da Escola de Engenharia de São Carlos, São Carlos, SP.

Utilizou-se um reator anaeróbio em escala de bancada do tipo reator em batelada seqüencial contendo biomassa imobilizada (ASBBR), o qual foi confeccionado em acrílico em formato cilíndrico, com dois tubos concêntricos com altura de $25 \mathrm{~cm}$, diâmetros internos de 19 e $22 \mathrm{~cm}$ e volume total de 7,2 L. Entre os tubos de diâmetros diferentes, havia circulação de água aquecida para manutenção da temperatura de operação. A Figura 4.4 mostra uma representação esquemática do reator e a Figura 4.5 mostra a montagem do sistema em funcionamento.

Dentro do reator, foi colocado um cesto de aço inoxidável perfurado, com malha de $0,5 \mathrm{~cm}$, diâmetro externo de $18 \mathrm{~cm}$ e altura de $18 \mathrm{~cm}$. O cesto tinha a forma de cilindro oco, contendo, na região central, o eixo do agitador mecânico com 2 impelidores tipo turbina, de lâminas planas verticais, posicionados na haste de agitação a $1 / 3$ e a $2 / 3$ do fundo do cesto de inox. A velocidade de agitação foi mantida em 300 rpm. O espaço interno do cesto foi preenchido com cubos de espuma de poliuretano de arestas de $1,0 \mathrm{~cm}$, densidade aparente de $23 \mathrm{~kg} / \mathrm{m}^{3}$ e porosidade aproximada de $95 \%$, que serviram como material suporte para imobilização da biomassa. 
O detalhe 12 da Figura 4.4 retrata o selo mecânico que foi feito na tampa do reator para evitar escape de gases pelo orifício de entrada da haste do agitador. Para isso, foi acoplado forçosamente neste orifício um tudo plástico de igual diâmetro que proporcionou máximo ajuste possível e evitou a perda do biogás atuando como um selo mecânico. Este tubo tinha $12 \mathrm{~cm}$ de altura e sua extremidade inferior ficava imersa no nível do líquido interno do reator. Dessa forma, o gás formado e armazenado no headspace (de altura 3,5 cm e volume de 0,85 L) não escapava do sistema por esta saída e sim pela saída de gás (detalhe 12, Figura 4.4) conectada ao sistema de medição de gás por deslocamento de líquido (detalhe 6, Figura 4.5).

O biogás produzido e armazenado no headspace do reator foi medido por deslocamento de líquido, em dispositivo externo e foi coletado em um recipiente graduado. O líquido utilizado foi água de abastecimento do laboratório, conforme pode ser observado na Figura 4.4 detalhe 6.

As operações de enchimento e descarga do reator foram realizadas por bombas do tipo diafragma, comandadas por temporizadores. A duração de cada uma dessas operações era de 10 minutos.

Antes de entrar no reator, a água residuária a ser tratada era aquecida até a temperatura de operação $\left(55{ }^{\circ} \mathrm{C}\right.$ e $35{ }^{\circ} \mathrm{C}$ para os processos termofílico e mesofílico, respectivamente), utilizando-se uma resistência elétrica, ligada a um termostato, a qual encontrava-se imersa no recipiente que acondicionava o substrato. 


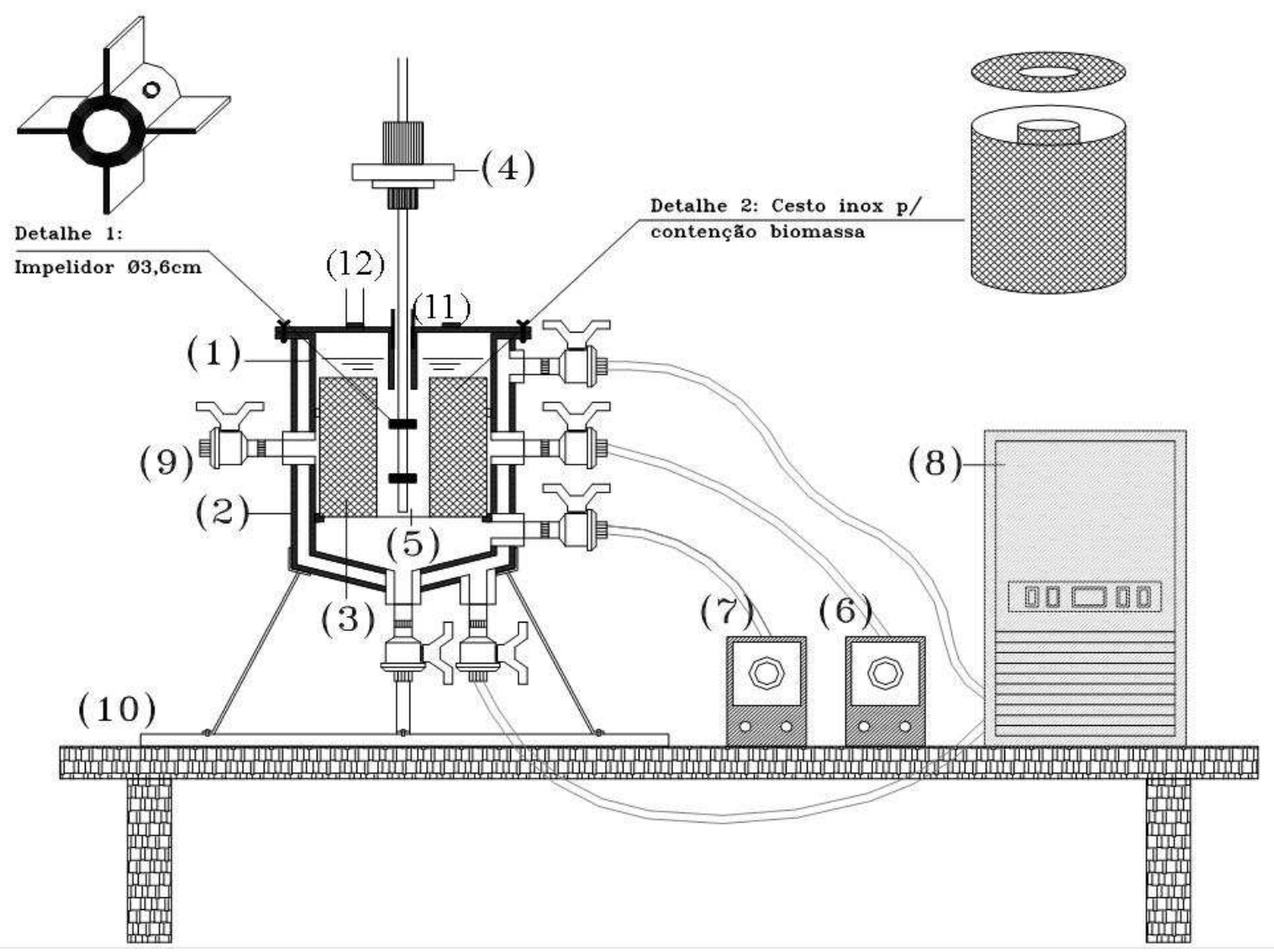

Figura 4.4 - Esquema do reator anaeróbio em batelada seqüencial, onde (1) reator anaeróbio em batelada seqüencial, (2) camisa de aquecimento, (3) cesto inoxidável, (4) agitador mecânico, (5) impelidor, (6) bomba de enchimento, (7) bomba de descarga, (8) banho ultratermostatizado, (9) amostrador, (10) bancada, (11) selo mecânico, (12) saída de biogás do headspace. Fonte: adaptado de Lapa (2003). 


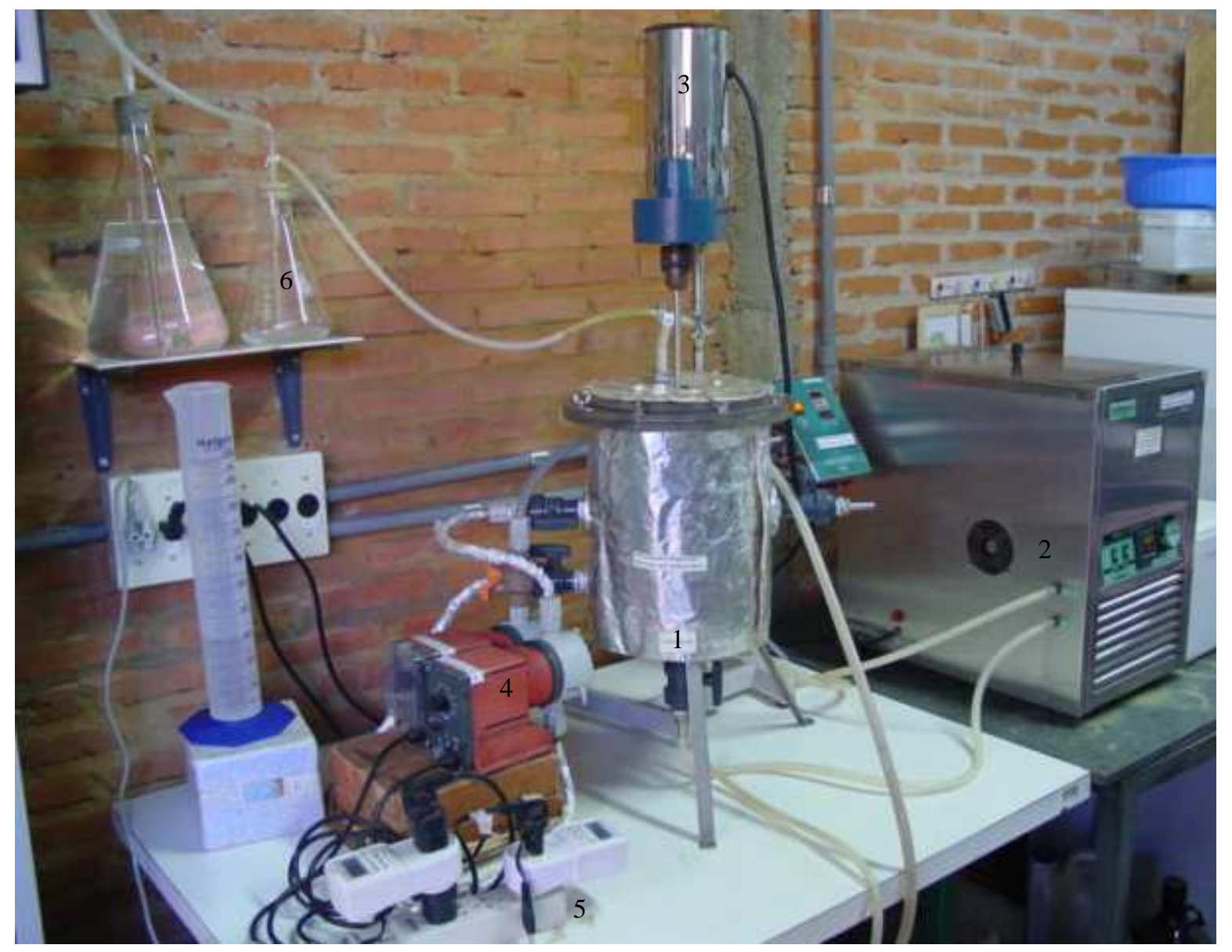

Figura 4.5 - Fotografia do sistema montado: (1) reator anaeróbio em batelada sequiencial, (2) banho ultratermostatizado, (3) agitador mecânico, (4) bombas de enchimento e de descarga, (5) temporizadores para acionamento das bombas, (6) sistema para medição de gás por deslocamento de líquido.

\subsection{Procedimento de inoculação do reator}

O reator foi inoculado com lodo biológico granulado proveniente de reator anaeróbio de fluxo ascendente e manta de lodo (UASB) de $990 \mathrm{~m}^{3}$, utilizado para o tratamento das águas residuárias de abatedouro de aves (Dacar Industrial S/A, em Tietê/SP) com tempo de detenção hidráulica de 1,65 dia. As características principais do lodo de inóculo utilizado estão apresentadas na Tabela 4.3. 
Tabela 4.3 - Características principais do lodo granulado de inóculo utilizado.

\begin{tabular}{cc}
\hline Parâmetro & Média \pm DP* \\
\hline Sólidos Totais (g/L lodo) & $37,1 \pm 1,56$ \\
Sólidos Voláteis Totais (g/L lodo) & $31,8 \pm 1,13$ \\
Sólidos Fixos Totais (g/L lodo) & $5,3 \pm 0,42$ \\
\hline
\end{tabular}

* DP - desvio padrão.

\subsubsection{Imobilização da biomassa}

O inóculo anaeróbio foi imobilizado em cubos de espuma de poliuretano, de acordo com metodologia proposta por Zaiat et al. (1994). Para atingir a imobilização, os autores recomendam que seja pesada uma quantidade de cubos secos de forma a preencher todo cesto de aço inoxidável e misturada com lodo granulado (anteriormente triturado em liquidificador) homogeneamente. Essa mistura deve permanecer em repouso por pelo menos 2 horas. Decorrido esse período, as matrizes com células aderidas foram alocadas no cesto dentro do reator para iniciar o processo de partida e adaptação do sistema.

\subsubsection{Quantificação da biomassa aderida}

A biomassa aderida foi indiretamente quantificada no momento da inoculação e quando o reator se apresentava estável em cada fase experimental, de acordo com procedimentos para a análise de sólidos voláteis totais descritos no APHA (1995).

Para a quantificação da biomassa aderida foram coletados cerca de 10 cubos de espuma de poliuretano do interior do reator que foram macerados e lavados com água destilada para que a biomassa se desprendesse. Os cubos de espuma isentos de lodo foram separados e secos somente em estuda a $105{ }^{\circ} \mathrm{C}$ para que fosse possível obter o peso seco do suporte. E, a biomassa desprendida foi seca em estufa na mesma temperatura e posteriormente, na mufla a $550^{\circ} \mathrm{C}$. 


\subsection{Procedimento experimental}

O experimento foi executado em duas etapas. Na primeira, foi avaliada a eficiência do reator anaeróbio, operado em bateladas seqüenciais com biomassa imobilizada em espuma de poliuretano, submetido ao aumento gradativo da concentração da água residuária em condições termofílicas $\left(55 \pm 2{ }^{\circ} \mathrm{C}\right)$ e a segunda, em condições mesofílicas $\left(35 \pm 2{ }^{\circ} \mathrm{C}\right)$. A partir do momento em que se promovia o aumento da concentração de matéria orgânica, iniciava-se uma nova fase experimental. A operação em condições termofílicas foi composta de sete fases experimentais e, em condições mesofílicas, seis fases. As mudanças das concentrações da matéria orgânica de entrada eram feitas depois que o reator atingia o equilíbrio dinâmico aparente (ou estabilidade), em que não foram constatadas variações de aproximadamente $20 \%$ da DQO do efluente em, pelo menos, três ciclos consecutivos, quando eram realizados os perfis temporais que marcavam o final de cada fase experimental.

As etapas experimentais foram realizadas com a finalidade de aplicar maior carga orgânica possível no reator. Assim, a carga orgânica volumétrica (COV) foi calculada de acordo com a equação 4.1 apresentada por Camargo (2000) para reatores batelada:

$\operatorname{COV}=\frac{V_{a f} \times C_{a f}}{t_{c} \times V_{u t}}$

Em que $\mathrm{V}_{a f}$ correspondeu ao volume de afluente que foi adicionado no reator (L), $\mathrm{C}_{a f}$ é a concentração do afluente (neste caso, em DQO, g/L), $\mathrm{t}_{c}$ é o tempo de ciclo (d) e $\mathrm{V}_{u t}$ é o volume útil do reator (L).

Como o regime era batelada, todo o volume útil do reator era trocado a cada novo ciclo. Dessa forma, o volume afluente correspondia ao volume útil.

\subsubsection{Estimativa dos parâmetros cinéticos}

Os parâmetros cinéticos obtidos nos perfis ao longo do ciclo foram analisados com base nas velocidades de conversão da matéria orgânica, obtidas através de ajustes dos modelos matemáticos aos dados experimentais. 
Aos dados obtidos com os perfis temporais de decaimento de DQO centrifugada ao longo de um ciclo de cada fase experimental, foram ajustados modelos cinéticos de primeira ordem. O método de ajuste utilizado foi o de Levenberg-Marquadt:

$$
C_{S}=C_{S R}+\left(C_{S o}-C_{S R}\right) \times e^{-K_{1}^{a p p} . t}
$$

Nesta expressão, $\mathrm{C}_{S}$ é a concentração do efluente amostrada em um tempo (t), $\mathrm{k}_{1}{ }^{\text {app }}$ é a constante cinética aparente de primeira ordem, $\mathrm{C}_{S o}$ é a concentração inicial e $\mathrm{C}_{S R}$ é a concentração residual do resíduo.

\subsection{Partida e fase de adaptação do reator em condições termofílicas}

Algumas estratégias operacionais, como variação do tempo de ciclo e suplementação de bicarbonato, foram realizadas com a finalidade de adaptar o inóculo mesofílico a condições termofílicas, além de adaptá-lo às características de composição da vinhaça. Estas estratégias operacionais estão apresentadas na Tabela 4.4.

Tabela 4.4 - Estratégias experimentais realizadas em etapas durante a partida e fase de adaptação do inóculo em condições termofílicas.

\begin{tabular}{c|c|c|c|c|c}
\hline $\begin{array}{c}\text { Etapas da } \\
\text { adaptação }\end{array}$ & $\begin{array}{c}\text { Duração } \\
(\mathbf{d})\end{array}$ & $\begin{array}{c}\text { Temperatura } \\
\left({ }^{\mathbf{0}} \mathbf{C}\right)\end{array}$ & $\begin{array}{c}\mathbf{t}_{\mathbf{c}}(\mathbf{d}) \\
(\mathbf{n c})^{*}\end{array}$ & $\begin{array}{c}\text { DQO } \\
\text { afluente } \\
(\mathbf{g} / \mathbf{L})\end{array}$ & $\begin{array}{c}\text { Suplementação de } \\
\text { Alcalinidade Afluente } \\
\left(\mathbf{g} \text { HCO }{ }_{\mathbf{3}} \text { /g DQO) }\right.\end{array}$ \\
\hline$a$ & 14 & 35 & $1(14)$ & 1,0 & 0,00 \\
$b$ & 5 & 35 & $1(5)$ & 1,0 & 0,36 \\
$c$ & 2 & 35 & $1(2)$ & 1,0 & 0,73 \\
$d$ & 7 & 55 & $1(7)$ & 1,0 & 1,20 \\
$e$ & 4 & 55 & $2(2)$ & 1,0 & 1,20 \\
$f$ & 18 & 55 & $2(9)$ & 1,0 & 1,20 \\
\hline
\end{tabular}

* $\mathrm{t}_{\mathrm{c}}-$ tempo de ciclo (número de ciclos).

Na etapa termofílica, o reator foi inoculado em 31/03/2004 e a fase considerada de adaptação estendeu-se por 50 dias, até a data de 20/05/2004. 
Nesse período, o substrato utilizado foi preparado em laboratório, de maneira a apresentar características semelhantes à vinhaça. Essa medida tornou-se necessária devido ao fato de a partida do reator ter ocorrido em época coincidente com a entressafra da cana-de-açúcar. Com essa finalidade, simulou-se o processamento de álcool de acordo com as orientações técnicas para produção de cachaça (MUTTON \& MUTTON, 2002) colocando-se 1,0 L de caldo de cana ( $\mathrm{pH} 5,0,6{ }^{\circ}$ Brix) para fermentar com $15 \mathrm{~g}$ de levedura comercial Saccharomyces cerevisiae por 24 horas, à temperatura de $32{ }^{\circ} \mathrm{C}$ até que o valor de Brix se estabilizasse, pois o açúcar medido indiretamente em Brix deve se transformar em álcool, que não pode ser quantificado dessa forma por não permitir a leitura em refratômetro, aparelho utilizado na medição de concentração de açúcar em sumos naturais de forma geral. Esse mosto foi fervido por 30 minutos para que o álcool formado fosse evaporado, conforme o processo de destilação.

A suplementação de minerais foi feita somente na última etapa da fase de adaptação, fase $f$, conforme solução de nutrientes elaborada por del Nery (1987).

\subsection{Operação do reator sob condições termofílicas tratando vinhaça de cana-de- açúcar}

Os experimentos sob condições termofílicas corresponderam a sete etapas (Tabela 4.5) de operação do ASBBR tratando vinhaça proveniente da produção de álcool de cana-de-açúcar.

O aumento do tempo de ciclo foi necessário em algumas fases experimentais para assegurar, cautelosamente, que a biomassa já adaptada às condições termofílicas não receberia cargas orgânicas de choque. Portanto, foram realizados perfis temporais prévios, ou seja, realizados logo após as mudanças de fases, de degradação de DQO, de consumo de AVT, de produção de $\mathrm{AB}$ e a medida de $\mathrm{pH}$. Esses perfis foram realizados nas fases III, IV, V e VII para comprovar se haveria necessidade de maior tempo de ciclo que o desejado (que era de 1 dia) e para as fases III e IV, em que o reator seria submetido a 5 e 10 gDQO/L.d, e de 2 dias para as demais fases (V, VI e VII, em que o reator seria submetido a valores de COV de 10 a 20 gDQO/L.d).

Dessa forma, com os dados dos perfis prévios, poderia ser obtido o tempo de ciclo suficiente para degradação do resíduo em cada concentração aplicada, prevenindo possível inibição das arquéias metanogênicas que atuam tardiamente na batelada ou que consomem os metabólitos finais dos grupos anteriores e estão envolvidos na digestão 
anaeróbia. Esses perfis eram realizados após 3 ciclos de um dia, a partir de quando se mudavam as condições de cada fase.

Após ajuste dos tempos de ciclo, de acordo com cada perfil temporal realizado nas distintas fases, as condições operacionais que foram adotadas estão apresentadas na Tabela 4.5. 
Tabela 4.5 - Condições experimentais adotadas em cada fase após análise do tempo de ciclo para cada concentração de vinhaça em condições termofílicas.

\begin{tabular}{|c|c|c|c|c|c|c|c|}
\hline Fase & DQO (g/L) & $t_{c}(d)$ & $\operatorname{COV}$ (g/L.d) & $\mathrm{HCO}_{3}^{-} / \mathrm{DQO}$ & Duração (d) & Ciclos & Condições adotadas \\
\hline Adaptação & 1,0 & $1-2$ & $0,5-1,0$ & $0-1,2$ & 50 & $1^{\circ}-39^{\circ}$ & \\
\hline I & 1,0 & 1,0 & 1,0 & 1,2 & 8 & $40^{\circ}-48^{\circ}$ & 8 ciclos $-1 d$ \\
\hline II & 2,5 & 1,0 & 2,5 & 0,8 & 22 & $49^{\circ}-70^{\circ}$ & 22 ciclos $-1 \mathrm{~d}$ \\
\hline III & 5,0 & 1,5 & 3,3 & 0,8 & 35 & $71^{\circ}-94^{\circ}$ & $\begin{array}{c}3 \text { ciclos }-1 \mathrm{~d} \\
\text { Perfil prévio }-3 \mathrm{~d} \\
19 \text { ciclos }-1,5 \mathrm{~d} \\
\end{array}$ \\
\hline IV & 10,0 & 3,0 & 3,3 & 0,6 & 13 & $95^{\circ}-101^{\circ}$ & $\begin{array}{c}3 \text { ciclos }-1 \mathrm{~d} \\
\text { Perfil prévio }-4 \mathrm{~d} \\
2 \text { ciclos }-3 \mathrm{~d}\end{array}$ \\
\hline V & 20,0 & 6,0 & 3,3 & 0,6 & 111 & $102^{\circ}-123^{\circ}$ & $\begin{array}{c}3 \text { ciclos }-1 \mathrm{~d} \\
\text { Perfil prévio }-6 \mathrm{~d} \\
17 \text { ciclos }-6 \mathrm{~d}\end{array}$ \\
\hline VI & $5,0-15,0$ & $1,5-3,0$ & $3,3-6,6$ & 0,4 & 109 & $124^{\circ}-170^{\circ}$ & $\begin{array}{c}8 \text { ciclos }- \text { tc } 1,5 \mathrm{~d}(12 \mathrm{~d}) \\
5 \mathrm{gDQO} / \mathrm{L}-\mathrm{COV} 3,3 \mathrm{~g} / \mathrm{L} . \mathrm{d} \\
10 \text { ciclos }- \text { tc } 3,0 \mathrm{~d}(30 \mathrm{~d}) \\
10 \mathrm{gDQO} / \mathrm{L}-\mathrm{COV} 3,3 \mathrm{~g} / \mathrm{L} . \mathrm{d} \\
3 \mathrm{ciclos}-\mathrm{tc} 1,5 \mathrm{~d}(4,5 \mathrm{~d}) \\
10 \mathrm{gDQO} / \mathrm{L}-\mathrm{COV} 6,6 \mathrm{~g} / \mathrm{L} . \mathrm{d} \\
25 \text { ciclos }-\mathrm{tc} 2,5 \mathrm{~d}(63 \mathrm{~d}), 10-15 \mathrm{gDQO} / \mathrm{L}- \\
\text { COV } 4-6 \mathrm{~g} / \mathrm{L} . \mathrm{d}\end{array}$ \\
\hline VII & 10,0 & 2,0 & 5,0 & 0,6 & 43 & $171^{\circ}-194^{\circ}$ & $\begin{array}{c}3 \text { ciclos }-1 \mathrm{~d} \\
\text { Perfil prévio }-2 \mathrm{~d} \\
19 \text { ciclos }-2 \mathrm{~d}\end{array}$ \\
\hline
\end{tabular}




\subsection{Operação do reator sob condições mesofílicas tratando vinhaça de cana-de- açúcar}

Os procedimentos de inoculação e imobilização da biomassa realizados dentro do reator foram os mesmos já descritos no item 4.3.

Durante os primeiros 17 dias, correspondentes ao período de arraste de biomassa não aderida ao suporte, o reator foi alimentado com um substrato composto por etanol (aproximadamente 2,5 $\mathrm{gDQO} / \mathrm{L}$ ), sais minerais e bicarbonato com o objetivo de enriquecer o lodo com microrganismos metanogênicos. Depois deste período, o etanol foi substituído por vinhaça (do lote coletado em setembro/05) adicionada até atingir a mesma concentração. A Tabela 4.6 resume as condições experimentais na fase de enriquecimento do lodo metanogênico do inóculo com duração de 21 dias.

Tabela 4.6 - Condições experimentais realizadas durante o período de enriquecimento da biomassa em condições mesofílicas.

\begin{tabular}{c|c|c|c|c|c}
\hline Condições & $\begin{array}{c}\text { Duração } \\
(\mathbf{d})\end{array}$ & $\begin{array}{c}\mathbf{t}_{\mathbf{c}}(\mathbf{d}) \\
(\mathbf{n c}) *\end{array}$ & $\begin{array}{c}\text { DQO } \\
\text { afluente } \\
(\mathbf{g} / \mathbf{L})\end{array}$ & $\begin{array}{c}\text { Fonte de } \\
\text { carbono }\end{array}$ & $\begin{array}{c}\text { Suplementação de } \\
\text { Alcalinidade Afluente } \\
\left(\mathbf{H C O}_{3}-\mathbf{D Q O}\right)\end{array}$ \\
\hline I & 8 & $1(8)$ & 1,0 & Etanol & $1,00\left(1^{\mathrm{o}}\right.$ ao $8^{\mathrm{o}}$ ciclo $)$ \\
\hline II & 6 & $1(6)$ & 3,0 & Etanol & $\begin{array}{c}0,33\left(9^{\circ} \text { ciclo }\right)+ \\
0,17\left(10^{\circ} \text { ao } 14^{\circ} \text { ciclo }\right)\end{array}$ \\
\hline III & 3 & $1(3)$ & 5,0 & Etanol & $0,10\left(15^{\circ}\right.$ ao $17^{\circ}$ ciclo $)$ \\
\hline IV & 4 & $1(4)$ & 2,5 & Vinhaça & $0,40\left(18^{\circ}\right.$ ao $21^{\circ}$ ciclo $)$ \\
\hline
\end{tabular}

*nc - números de ciclos.

As condições operacionais adotadas de toda fase mesofílica após a fase de enriquecimento do inóculo estão discriminadas na Tabela 4.7.

Tabela 4.7 - Condições experimentais adotadas em cada fase experimental para cada concentração de vinhaça em condições mesofílicas.

\begin{tabular}{ccccccc}
\hline Fase & $\begin{array}{c}\text { DQO } \\
(\mathbf{g} / \mathbf{L})\end{array}$ & $\begin{array}{c}\mathbf{t}_{\mathbf{c}} \\
(\mathbf{d})\end{array}$ & $\begin{array}{c}\mathbf{C O V} \\
(\mathbf{g} / \mathbf{L} . \mathbf{d})\end{array}$ & $\mathbf{H C O}_{\mathbf{3}}{ }^{-} / \mathbf{D Q O}$ & $\begin{array}{c}\text { Duração } \\
(\mathbf{d})\end{array}$ & Ciclos \\
\hline Enriquecimento & $1,0-5,0$ & 1 & $1,0-5,0$ & $0,1-1,0$ & 21 & $1^{\mathbf{0}}-21^{\circ}$ \\
I & 2,5 & 1 & 2,5 & 0,4 & 4 & $22^{\mathrm{o}}-25^{\circ}$ \\
II & 5,0 & 1 & 5,0 & 0,4 & 16 & $26^{\circ}-42^{\circ}$ \\
III & 7,5 & 1 & 7,5 & 0,3 & 9 & $43^{\circ}-52^{\circ}$ \\
IV & 10,0 & 1 & 10,0 & $0,1-0,2$ & 29 & $53^{\circ}-82^{\circ}$ \\
V & 20,0 & 1 & 20,0 & 0,2 & 6 & $83^{\circ}-89^{\circ}$ \\
VI & 30,0 & 1 & 30,0 & 0,2 & 4 & $90^{\circ}-94^{\circ}$ \\
\hline
\end{tabular}




\subsubsection{Testes de atividade metanogênica específica}

Os testes de atividades metanogênicas foram realizados com amostras de biomassa retiradas do reator operado em condições mesofílicas na última etapa experimental com carga orgânica volumétrica de aproximadamente 30 g/L.d. A atividade metanogênica foi avaliada segundo Steil (2001), que consistiu em determinar por cromatografia gasosa, a concentração de metano do biogás produzido no headspace (volume de $40 \mathrm{~mL}$ ) de frascos tipo penicilina de capacidade total de $100 \mathrm{~mL}$ até observar estabilização do gás medido. Em cada frasco, foi mantida uma relação S/X de 0,25, que correspondeu a $10 \%$ de inóculo medido como SSV (sólidos suspensos voláteis), tendo como fonte de carbono acetato de sódio $50 \mathrm{mM}$.

A área de metano medida foi transformada em mmols de $\mathrm{CH}_{4}$ (CNTP) pela equação da curva de calibração do cromatógrafo e foi calculado o metano do headspace:

$\mathrm{n}^{\circ}$ de mols de $\mathrm{CH}_{4}$ no headspace $(\mathrm{mmol})=\frac{\left[\mathrm{CH}_{4}\right] \text { na amostra }(\mathrm{mmol}) \times \text { volume do headspace }(\mathrm{mL})}{\text { volume injetado da amostra }(\mathrm{mL})}$

O meio de cultura foi composto por meio basal Zinder, tendo acetato como fonte de carbono (ZINDER et al., 1984), e suplementado com metais traço, vitaminas (TOUZEL \& ALBAGNAC, 1983; DUBOURGUIER, 1987), bicarbonato de sódio e solução redutora de sulfeto de sódio. O protocolo de preparo das soluções está detalhadamente descrito em Vich (2006) e Steil (2001).

\subsection{Análises físico-químicas}

As análises físico-químicas de monitoramento para avaliar o comportamento do reator foram $\mathrm{DQO}, \mathrm{pH}$, alcalinidade a bicarbonato e ácidos voláteis totais, realizadas duas vezes por semana, até o sistema alcançar a estabilidade dinâmica aparente em cada fase experimental. Atingida a estabilidade, foram realizados perfis temporais de decaimento de $\mathrm{DQO}$, produção e consumo de ácidos orgânicos, $\mathrm{pH}$, produção e composição de biogás $\left(\mathrm{CO}_{2}\right.$ e $\left.\mathrm{CH}_{4}\right)$ e fenol. Em seguida, a biomassa foi caracterizada através de exames microbiológicos quanto às morfologias presentes e quantificada pela determinação de sólidos voláteis totais. 
As análises de ácidos orgânicos voláteis foram realizadas por cromatografia gasosa, utilizando-se cromatógrafo HP 6890, com detector de ionização de chama segundo metodologia desenvolvida por Moraes et al. (2001). O fenol foi quantificado pela mesma metodologia, com tempo de retenção maior que os dos ácidos orgânicos e com curva padrão própria para fenol.

A composição do biogás foi realizada por cromatografia gasosa por cromatógrafo Gow-Mac com detector de condutividade térmica e coluna "Porapk Q" ( $2 \mathrm{~m}$ x 1/4" - 80 a $100 \mathrm{mesh}$ ) e gás de arraste $\mathrm{H}_{2}$ a $1,0 \mathrm{~mL} / \mathrm{s}$.

Torna-se importante esclarecer que as análises de DQO, ácidos orgânicos, AVT, alcalinidade a bicarbonato, foram feitas com o sobrenadante de amostras centrifugadas a $2500 \mathrm{rpm}$ por 4 minutos e o $\mathrm{pH}$ foi medido em amostras brutas.

O procedimento de centrifugação foi adotado ao longo de todo experimento, após ter sido realizada análise estatística das médias obtidas em diferentes procedimentos de preparação das amostras a fim de compará-los. As médias de dois lotes de vinhaça sem diluição foram comparadas entre si utilizando-se o teste estatístico Tukey com delineamento inteiramente casualizado e três repetições considerando nível de significância de $95 \%$ pelo software Estat ${ }^{\circledR}$. Os procedimentos avaliados foram: $(i)$ DQO total ou bruta, (ii) DQO filtrada em membrana de 1,2 $\mu \mathrm{m}$, (iii) DQO filtrada em membrana de $0,45 \mu \mathrm{m}$ e (iv) DQO centrifugada a $2500 \mathrm{rpm}$ por 4 minutos.

A média dos resultados obtidos dos lotes de vinhaça avaliados bem como a análise estatística dos dados está apresentada na Tabela 4.8.

Tabela 4.8 - Média de três repetições e desvio padrão (DP) de amostras de DQO preparadas por diferentes procedimentos avaliados.

\begin{tabular}{lccccc}
\hline \multirow{2}{*}{\multicolumn{1}{c}{ Procedimentos }} & \multicolumn{4}{c}{ Média de DQO \pm DP $(\mathbf{g} / \mathbf{L})$} \\
\cline { 2 - 5 } & \multicolumn{3}{c}{ Lote 14/05/04 } & \multicolumn{2}{c}{ Lote 24/09/04 } \\
\hline DQO bruta ou total & $45,73 \pm 0,93$ & $\boldsymbol{a}$ & $44,99 \pm 0,79$ & $\boldsymbol{a}$ \\
DQO filtrada - membrana $1,2 \mu \mathrm{m}$ & $39,77 \pm 0,28$ & $\boldsymbol{b c}$ & $37,89 \pm 0,28$ & $\boldsymbol{b} \boldsymbol{c}$ \\
DQO filtrada - membrana $0,45 \mu \mathrm{m}$ & $38,05 \pm 0,75$ & $\boldsymbol{c}$ & $36,33 \pm 0,75$ & $\boldsymbol{c}$ \\
DQO centrifugada - 2500 rpm/4 minutos & $40,83 \pm 0,57$ & $\boldsymbol{b}$ & $39,19 \pm 1,77$ & $\boldsymbol{b}$ \\
\hline
\end{tabular}

Médias comparadas em cada coluna seguidas pela mesma letra não são significativamente diferentes de acordo com o Teste de Tukey $(\mathrm{P}<0,05)$.

Os fatores que levaram à escolha do procedimento de centrifugação foram: o menor custo, praticidade e não comprometimento dos dados comparados com a filtração em membrana $1,2 \mu \mathrm{m}$, pois não foi observada diferença significativa ao nível de $5 \%$ 
nos valores obtidos nos procedimentos de filtração em membrana $1,2 \mu \mathrm{m}$ e de centrifugação. Além disso, foi observado obstrução dos poros nessa malha de membrana que dificultava o preparo das amostras.

O método de filtração em membrana $1,2 \mu \mathrm{m}$ também não diferiu estatisticamente do procedimento de filtração em membrana 0,45 $\mu \mathrm{m}$ das amostras de vinhaça de ambos os lotes avaliados.

A produção de biogás dos perfis realizados no ASBBR foi medida por deslocamento de líquido (que era água de abastecimento) em cada tempo amostrado, conforme detalhe 6 da Figura 4.5.

Com a análise cromatográfica, foi possível estabelecer as frações de metano e gás carbônico que eram produzidas separadamente e que eram amostrados em intervalos de tempos definidos em cada perfil. Para calcular a produção de biogás, utilizou-se a equação da curva de calibração do cromatógrafo (em mmol/volume amostrado), assim foi possível extrapolar para o volume de água deslocado, que foi considerado o volume de biogás total produzido (em mol de $\mathrm{CH}_{4}$ ou $\mathrm{CO}_{2}$ /volume de biogás produzido ou deslocado num intervalo de tempo). Em todos os cálculos, a produção dos gases foi corrigida para CNTP onde: $\mathrm{P}_{\mathrm{atm}}=694 \mathrm{mmHg}, \mathrm{R}=62,4, \mathrm{~T}=$ temperatura de operação $\left({ }^{\circ} \mathrm{C}\right)+273 \mathrm{~K}$. Assim, pela fórmula PV $=\mathrm{nRT}$ foi possível estabelecer o volume de biogás produzido por tempo amostrado $\left(\mathrm{L} \mathrm{CH}_{4}\right.$ ou $\left.\mathrm{CO}_{2} / \mathrm{h}\right)$.

\subsection{Exames microbiológicos}

Amostras do inóculo (início da operação do sistema) e do material suporte (final de cada condição operacional) retiradas dos pontos junto à superfície, meio e fundo do cesto do reator foram examinadas por microscopia ótica de luz comum e fluorescência em microscópio Leica DM LB pelo programa de análise de imagens Image Pro Plus 4.5 e por microscopia eletrônica de varredura (MEV) em microscópio de varredura digital LEO - 440 DSM-9601.

Para exame em MEV, as amostras foram preparadas de acordo com protocolo experimental desenvolvido por Nation (1983) e adaptado para biofilme por Araújo (1995) que consistiu basicamente em: fixar as amostras com glutaraldeído 2,5\% em tampão fosfato $0,1 \mathrm{M}$ a pH 7,3 gelado; gelar as amostras por 12 horas a $4{ }^{\circ} \mathrm{C}$; em seguida, lavar as amostras por vezes com tampão fosfato $0,1 \mathrm{M}$ a pH 7,3 gelado com duração de 10 minutos cada lavagem; deixar as amostras de molho por 10 minutos em 
cada concentração de álcool etílico 50, 70, 80, 90, 95 e $100 \%$ para desidratação das amostras. Enfim, as amostras foram aderidas às placas suportes de MEV e secas em estufa a $40^{\circ} \mathrm{C}$ por 2 horas. Em seguida, foram recobertas com ouro e examinadas.

A diversidade microbiana foi avaliada somente nas amostras do inóculo e da biomassa termofílica ao final da fase VII usando-se a técnica molecular PCR/DGGE (reação de polimerização em cadeia - PCR/ eletroforese em gel com gradiente desnaturante - DGGE) descrito por Muyzer (1999) com primers de arquéia e bactéria, usados por Nübel et al. (1996) e Großkopf et al. (1998), respectivamente. O coeficiente de similaridade $\left(\mathrm{C}_{\text {similar }}\right)$ entre as bandas do DGGE foi calculado segundo Gillan et al. (1998):

$$
C_{\text {similar }}=\frac{2 j}{(a+b) .100}
$$

Em que $a$ era o número de bandas do DGGE do biofilme 1 que, no caso, era o inóculo, $b$ era o número de bandas do DGGE do biofilme 2, amostra retirada no final do experimento termofílico fase VII e $j$ era o número de bandas comuns. Se $\mathrm{C}_{\text {similar }}$ fosse $100 \%$ os perfis de DGGE seriam idênticos e se $\mathrm{C}_{\text {similar }}$ fosse $0 \%$ os perfis de DGGE seriam completamente diferentes.

\subsection{Ensaios complementares com substrato sintético semelhante à vinhaça obtida durante o processamento de açúcar de beterraba}

A fim de verificar a versatilidade da biomassa anaeróbia termofílica que vinha tratando vinhaça de cana-de-açúcar em ASBBR (de 7,2 L) quanto à sua adaptação em diferentes substratos e condições de temperatura, foram realizados monitoramentos de eficiência de remoção de DQO e de ácidos orgânicos em outro ASBBR (de 0,8 L) com vinhaça sintética semelhante àquela originada no processamento da beterraba.

Ao mesmo tempo, foram ensaiados dois frascos-reatores inoculados com lodo granular proveniente de reator UASB que tratava água residuária de abatedouro de aves e que foi inicialmente usado como inóculo do ASBBR de 7,2 L no tratamento de vinhaça de cana-de-açúcar. Um dos frascos foi operado à temperatura termofílica e outro à temperatura mesofílica. Os frascos foram alimentados com substrato sintético semelhante à vinhaça originada durante o processamento da beterraba para produção de açúcar. Finalmente, foram realizados ensaios de biodegradabilidade anaeróbia com biomassa usada como inóculo dos frascos-reatores. 
O detalhamento destes experimentos é relatado a seguir.

Esta etapa do trabalho foi desenvolvida nas dependências do Laboratório de Águas do Departamento de Engenharia Química da Universidad de Valladolid, cidade de Valladolid, Espanha.

\subsubsection{Ensaios com biomassa imobilizada em ASBBR}

Com o objetivo de se avaliar o comportamento da biomassa anaeróbia utilizada ao longo da primeira parte de todo experimento (cerca de 360 dias), com vinhaça de cana-de-açúcar e que já estava adaptada em condições termofílicas $\left(55{ }^{\circ} \mathrm{C}\right)$, uma amostra foi retirada deste reator e submetida a alimentação com substrato sintético semelhante a vinhaça obtida no processamento de beterraba para produção de açúcar.

A amostra foi retirada na última fase experimental, fase VII, do ASBBR que operava a $55{ }^{\circ} \mathrm{C}$ tratando vinhaça de cana-de-açúcar. Alguns cubos de espumas de dentro do reator foram retirados e espremidos, de forma a separar maior quantidade possível de biomassa da espuma de poliuretano. $O$ material desprendido foi acondicionado em frasco plástico fechado envolto em papel para ser transportado.

$\mathrm{Na}$ Espanha, este frasco foi armazenado em temperatura de $4-5{ }^{\circ} \mathrm{C}$ por 41 dias. Em seguida, a biomassa foi re-inoculada em novas matrizes de espumas de poliuretano.

Uma réplica do reator utilizado na EESC/USP em menor escala foi construído em acrílico, com altura de 9,8 cm e diâmetro de $11 \mathrm{~cm}$ e volume total de $0,8 \mathrm{~L}$ (Figura 4.6), preenchido com 250 cubos de espuma de poliuretano (densidade aparente de $23 \mathrm{~kg} / \mathrm{m}^{3}$ e porosidade de $95 \%$ ) com arestas de $1 \mathrm{~cm}$ (pesando ao total 6,38 g), sendo que ocupavam um volume de 0,3 L. O volume destinado ao headspace foi de aproximadamente $0,1 \mathrm{~L}$ e volume útil de 0,4 L. Foram adicionados cerca de 1,32 g SVT a cada $\mathrm{g}$ de espuma, totalizando no reator todo aproximadamente $8,42 \mathrm{~g}$ de SVT.

Após a inoculação, o reator permaneceu em constante agitação de $100 \mathrm{rpm}$. Para a manutenção da temperatura $\left(55 \pm 5^{\circ} \mathrm{C}\right)$, o reator foi colocado dentro de uma estufa.

O substrato sintético de composição similar à vinhaça proveniente do processamento da beterraba, continha (em g/L): 30,72 betaína, 4,38 ácido acético, 3,08 ácido propiônico, 2,57 ácido butírico, 12,56 glucose; 2,67 $\mathrm{Na}_{2} \mathrm{SO}_{4}$; 0,164 $\mathrm{MgCl}_{2} .6 \mathrm{H}_{2} \mathrm{O}$, 0,02 $\mathrm{CaCl}_{2}, 0,5 \mathrm{KH}_{2} \mathrm{PO}_{4}, 5,12 \mathrm{NaH}_{2} \mathrm{PO}_{4}$; e $10 \mathrm{~mL} / \mathrm{L}$ de solução de elementos traços contendo $(\mathrm{mg} / \mathrm{L}): 2000 \mathrm{FeCl}_{3} \cdot 4 \mathrm{H}_{2} \mathrm{O}, 2000 \mathrm{CoCl}_{2} \cdot 6 \mathrm{H}_{2} \mathrm{O}, 500 \mathrm{MnCl}_{2} \cdot 4 \mathrm{H}_{2} \mathrm{O}, 30$ 
$\mathrm{CuCl}_{2} .2 \mathrm{H}_{2} \mathrm{O}, 50 \mathrm{ZnCl}_{2}, 50 \mathrm{H}_{3} \mathrm{BO}_{3}, 49 \mathrm{Mo}, 100 \mathrm{Na}_{2} \mathrm{SeO}_{3} .5 \mathrm{H}_{2} \mathrm{O}, 50 \mathrm{NiCl}_{2} .6 \mathrm{H}_{2} \mathrm{O}, 1000$ EDTA; pH ajustado para 7,2 com $\mathrm{NaOH}$ e 10 g/L tampão $\mathrm{NaHCO}_{3}$.

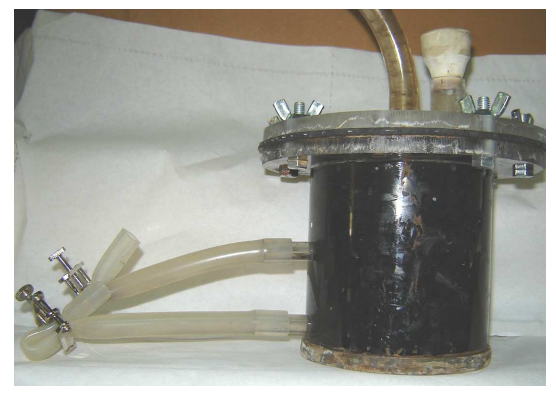

Figura 4.6 - Fotografia do ASBBR tratando substato sintético semelhante à vinhaça de beterraba.

A readaptação da biomassa e a operação do reator tratando substrato sintético semelhante à vinhaça de beterraba foram realizadas em várias fases que estão apresentadas na Tabela 4.9.

Tabela 4.9 - Fases experimentais realizadas nos ensaios com ASBBR com substrato semelhante à vinhaça de beterraba.

\begin{tabular}{cccc}
\hline Fases & DQO $(\mathbf{g} / \mathbf{L})$ & $\mathbf{t}_{\mathbf{c}}(\mathbf{d})$ & $\mathbf{n c}^{*}(\mathbf{d})$ \\
\hline I & $8,5-10,0$ & 5 & $5\left(1-5^{\mathbf{o}}\right)$ \\
II & 0,5 & 1 & $2\left(6-7^{\circ}\right)$ \\
III & $1,5-2,0$ & 1 & $3\left(8-10^{\circ}\right)$ \\
IV & 3,0 & 1 & $33\left(11-44^{\circ}\right)$ \\
V & 8,0 & 1 & $4\left(45-48^{\circ}\right)$ \\
VI & 2,0 & 7 & $3\left(49-51^{\mathbf{o}}\right)$ \\
VII & 1,0 & 2 & $8\left(52-59^{\circ}\right)$ \\
VIII & 1,0 & 1 & $20\left(60-79^{\circ}\right)$ \\
\hline
\end{tabular}

*nc: número de ciclos.

O substrato foi diluído para obter composição segundo as fases experimentais. A partir da fase II, a diluição era feita com o próprio licor interno dos reatores, pois somente um volume de $20-25 \%$ do volume útil era reposto com o substrato.

As análises realizadas foram: $\mathrm{DQO}$, sólidos, $\mathrm{pH}$, nitrogênio de acordo com APHA (1995); ácidos orgânicos por cromatografia gasosa; sulfato por detector de condutividade e composição de gases por cromatografia líquida. 


\subsubsection{Ensaios com biomassa granulada suspensa em frascos-reatores}

O lodo granulado de reator UASB usado no tratamento das águas residuárias de abatedouro de aves (Dacar Industrial S/A, em Tietê/SP), que foi utilizado como inóculo dos ASBBR avaliados neste trabalho, também foi submetido a ensaios com substrato semelhante à vinhaça de beterraba com o objetivo de se avaliar o desempenho dos grânulos não adaptados tanto em condições mesofílicas $\left(35^{\circ} \mathrm{C}\right)$ como termofílicas $\left(55^{\circ} \mathrm{C}\right)$.

Este lodo estava armazenado a $4{ }^{\circ} \mathrm{C}$ por 6 meses e continha grânulos que permaneceram íntegros desde a sua coleta do reator que tratava água residuária de abatedouro de aves.

Dois reatores com biomassa granulada suspensa, um termofílico e outro mesofílico, receberam $50 \mathrm{~g}$ de lodo granular biológico anaeróbio (com aproximadamente $67,2 \mathrm{mg} \mathrm{SVT} / \mathrm{g}$ lodo, totalizando $3,4 \mathrm{~g}$ de SVT em cada reator) cada um. Cada reator que era constituído de frascos de vidro com volume total de 0,5 L, fechados com lacre de alumínio e tampa de borracha. Um reator foi ensaiado na temperatura mesofílica de $35 \pm 2{ }^{\circ} \mathrm{C}$ e outro na termofílica de $55 \pm 5{ }^{\circ} \mathrm{C}$.

As condições experimentais adotadas em cada fase nos frascos-reatores termofílico e mesofílico estão apresentadas na Tabela 4.10.

Tabela 4.10 - Fases experimentais realizadas nos ensaios com reator de biomassa granulada suspensa.

\begin{tabular}{cccc|ccc}
\hline \multirow{2}{*}{ Fases } & \multicolumn{3}{c|}{ Termofílico } & \multicolumn{3}{c}{ Mesofílico } \\
\cline { 2 - 7 } & $\mathbf{D Q O}(\mathbf{g} / \mathbf{L})$ & $\mathbf{t}_{\mathbf{c}}(\mathbf{d})$ & $\mathbf{n c}^{*}(\mathbf{d})$ & $\mathbf{D Q O}(\mathbf{g} / \mathbf{L})$ & $\mathbf{t}_{\mathbf{c}}(\mathbf{d})$ & $\mathbf{n c}(\mathbf{d})$ \\
\hline I & 2,0 & 1 & $3\left(1-3^{\circ}\right)$ & 2,0 & 1 & $3\left(1-3^{\circ}\right)$ \\
II & $3,0-3,5$ & $1-2$ & $9\left(4-23^{\circ}\right)$ & $3,0-3,5$ & $1-2$ & $9\left(4-23^{\circ}\right)$ \\
III & 2,0 & $1-2$ & $6\left(24-29^{\circ}\right)$ & 2,0 & $1-2$ & $6\left(24-29^{\circ}\right)$ \\
IV & 3,5 & $1-2$ & $7\left(30-40^{\circ}\right)$ & 3,5 & 1 & $10\left(30-40^{\circ}\right)$ \\
V & 1,0 & 7 & $3\left(40-43^{\circ}\right)$ & $2,5-3,0$ & 1 & $4\left(40-44^{\circ}\right)$ \\
VI & 1,0 & $2-3$ & $6\left(44-50^{\circ}\right)$ & $2,5-3,0$ & 7 & $1\left(45^{\circ}\right)$ \\
VII & 1,0 & 1 & $20\left(51-70^{\circ}\right)$ & 2,0 & 2 & $6\left(46-51^{\circ}\right)$ \\
VIII & - & - & - & 7,0 & 1 & $20\left(53-72^{\circ}\right)$ \\
\hline
\end{tabular}

*nc - número de ciclos. 


\subsubsection{Testes de biodegradabilidade anaeróbia}

Segundo Field (1988), o propósito deste tipo de ensaio é determinar a fração da DQO de uma água residuária que pode ser degradada anaerobiamente pelo lodo específico. Neste caso, os ensaios de biodegradabilidade anaeróbia foram realizados com o lodo granular utilizado como inóculo do reator de biomassa suspensa. $\mathrm{O}$ meio de cultivo foi água residuária sintética semelhante à vinhaça de beterraba que era utilizada como substrato do ASBBR (de 0,8 L) e dos frascos-reatores.

Foram preparados seis frascos tipo penicilina de volume total de $120 \mathrm{~mL}$ cada: dois deles foram incubados a $35^{\circ} \mathrm{C}$ e dois respectivos controles assim como, dois foram incubados a $55{ }^{\circ} \mathrm{C}$ e dois respectivos controles. Os frascos foram preenchidos com $50 \mathrm{~mL}$ de substrato (com $2600 \mathrm{mgDQO} / \mathrm{L}$ ) e ambos controles receberam somente água destilada no lugar do substrato.

Em cada frasco, foram adicionados $5 \mathrm{~g} \mathrm{SSV/L} \mathrm{para} \mathrm{manter} \mathrm{uma} \mathrm{relação} \mathrm{S/X}$ (substrato/microrganismo) de 0,5 (Cho et al., 2004). A quantificação dos sólidos suspensos voláteis foi feita pela pesagem da massa desejada sem considerar a fração ativa ou inativa do lodo por não existir metodologia disponível para quantificar separadamente a porção ativa de um lodo anaeróbio.

A produção de metano foi calculada a partir da medição da pressão dos frascos conforme protocolo experimental desenvolvido por Fdz-Polanco et al. (2004). 


\section{Resultados E DiscuSSÃo}

"Quanto mais um homem se aproxima de suas metas, tanto mais crescem as dificuldades." J. W. von Goethe

Neste capítulo, serão apresentados e discutidos os resultados obtidos (i) na caracterização dos principais componentes da vinhaça de cana para o tratamento anaeróbio, (ii) na fase de adaptação do inóculo mesofílico utilizado no tratamento anaeróbio da vinhaça de cana sob condições termofílicas, (iii) no monitoramento do ASBBR em condições termofílicas e aumento da concentração de vinhaça de cana, (iv) no monitoramento do ASBBR em condições mesofílicas, (v) bem como, serão apresentados e discutidos os resultados dos ensaios complementares com substrato sintético semelhante a vinhaça de beterraba. Por fim, os resultados obtidos no tratamento termofílico e mesofílico serão comparados e discutidos quanto à estabilidade dos processos e eficiência na remoção de matéria orgânica.

\subsection{Características da vinhaça obtida do processamento de cana-de-açúcar em} álcool e açúcar

A utilização do efluente industrial real neste trabalho teve por objetivo verificar a ocorrência de possíveis problemas que a indústria teria, caso optasse por esta configuração de reator como sistema de tratamento anaeróbio. Contudo, o maior inconveniente foi a variação das características da vinhaça ao longo da safra devido a fatores sazonais, que podem se modificar qualitativamente conforme as estações do ano, fatores climáticos e pela grande diversidade de variedades de cana-de-açúcar processadas em uma mesma dorna de fermentação. Esse fato dificultou o controle mais preciso das condições do reator quanto ao substrato a ser tratado. 
A Tabela 5.1 que também foi apresentada no capítulo 4 (Tabela 4.1), será reapresentada a seguir para facilitar o entendimento das discussões quanto aos resultados obtidos de alguns parâmetros usados para caracterizar os lotes coletados da água residuária utilizada nos experimentos. Foram coletados três lotes de vinhaça um em maio de 2004, outro em setembro de 2004 e outro em setembro de 2005.

Tabela 5.1 - Parâmetros físico-químicos de três diferentes lotes de vinhaça de cana-deaçúcar coletados em maio e setembro de 2004 e em setembro de 2005 usados como afluente nos experimentos (médias de duplicatas).

\begin{tabular}{lccc}
\hline & Maio/04 & Setembro/04 & Setembro/05 \\
\hline $\mathrm{pH}$ & 4,8 & 4,4 & 4,6 \\
Alcalinidade Total (mg CaCO $3 / \mathrm{L})$ & 1304 & 202 & 692 \\
Acidez Volátil Total (mg HAc/L) & 5900 & 2960 & 5296 \\
DQO (g/L) & 52 & 59 & 42 \\
Sólidos Totais (g/L) & 35,4 & 37,1 & 38,5 \\
$\quad$ Voláteis Totais (g/L) & 22,5 & 27,0 & 25,6 \\
$\quad$ Fixos Totais (g/L) & 12,5 & 10,2 & 12,9 \\
N-Total Kjeldahl (mg/L) & 587 & 6000 & 743 \\
P-Total (mg/L) & 55 & 44,1 & 73,9 \\
K-Total (mg/L) & 12500 & 1682 & 4309 \\
SO ${ }^{-2}$ (mg/L) & 1680 & 1920 & 1645 \\
Cor aparente (uCoPt) & 16140 & 39000 & n.d. \\
Condutividade (mS/cm) & 10,24 & 7,4 & 13,5 \\
\hline
\end{tabular}

n.d. não determinado.

Os lotes coletados em maio/04 e setembro/04 foram utilizados no tratamento termofílico e o lote coletado em setembro/05 foi usado como substrato no tratamento mesofílico.

Comparando-se os lotes coletados, observa-se que as características variaram significativamente, destacando-se os valores de alcalinidade total, acidez volátil total, nitrogênio, potássio e cor. Certamente, a composição da vinhaça varia de acordo com a constituição e diferentes culturas de cana-de-açúcar, que são resultados de vários fatores como tempo de colheita, variedade cultivada, tipo de solo local, condições climáticas, tecnologias de processamento da cana, dentre outros. Por exemplo, sabe-se que a 
concentração de sacarose da cana-de-açúcar produzida na região sudeste do Brasil é, geralmente, maior entre os meses de agosto e novembro (GAZETA MERCANTIL, 2005).

Pela composição dos sólidos, observa-se que a vinhaça proveniente do processamento de cana-de-açúcar é um resíduo orgânico em que aproximadamente $70 \%$ dos sólidos totais são substâncias voláteis. É também importante considerar que essa água residuária contém muitos sais dissolvidos, pois os valores de condutividade das amostras foram de 10,2, 7,4 e 13,5 mS/cm dos lotes de maio/04, setembro/04 e setembro/05, respectivamente. Para se ter uma idéia da significância desses valores a fim de comparação, pode-se citar, como exemplo, a água do mar, que pode apresentar $12 \mathrm{mS} / \mathrm{cm}$ (CARTER \& LOWE, 2005), águas residuárias de indústrias de conserva de azeitonas que podem atingir $25 \mathrm{mS} / \mathrm{cm}$, águas subterrâneas contaminadas com fertilizantes chegam a apresentar $0,85 \mathrm{mS} / \mathrm{cm}$, além de outros resíduos como das agroindústrias de charque, abatedouros ou de atividades de mineração, que também apresentam alta concentração de íons. Os íons que resultam em condutividade elétrica na vinhaça podem ser $\mathrm{Ca}^{2+}, \mathrm{Mg}^{2+}, \mathrm{Na}^{+}, \mathrm{K}^{+}$, fosfatos, sulfatos, $\mathrm{Cl}^{-}, \mathrm{NO}_{3}{ }^{-}$, dentre outros.

Mas, por ser um resíduo orgânico com sais minerais ainda disponíveis em quantidade considerável e energia, há potencial e viabilidade para biodegradação anaeróbia da matéria orgânica da vinhaça, restando os minerais no efluente após o tratamento.

Por cálculos, observa-se que a vinhaça de maio/04 apresentava uma relação DQO:N:P de 945:11:1, a de setembro/04 de 1341:136:1 e a de setembro/05 de 567:10:1, indicando que estas relações ultrapassam o valor ideal para desenvolvimento de microrganismos anaeróbios que é de 500:5:1 (SPEECE, 1996). Assim, a composição da vinhaça não era fator limitante nesse caso, de modo que a adição desses nutrientes $(\mathrm{C}$ e N) aos lotes de vinhaça utilizados não foi necessária, apesar do teor de fósforo não estar em acordo com a relação ótima para microrganismos anaeróbios.

Adiante, serão apresentados os resultados da partida do reator onde a adição de metais traço foi essencial para a adaptação do inóculo na degradação da vinhaça.

A adaptação do inóculo para as condições termofílicas foi feita utilizando-se água residuária produzida no laboratório, com composição semelhante à da vinhaça. Essa água residuária apresentava as seguintes características: $\mathrm{pH}$ 3,6, acidez volátil total de $2978 \mathrm{mg} / \mathrm{L}$, DQO de $96 \mathrm{~g} / \mathrm{L}$, sólidos totais de $127 \mathrm{~g} / \mathrm{L}$, sólidos voláteis totais de 126 g/L, sólidos suspendidos totais de $122 \mathrm{~g} / \mathrm{L}$, sólidos suspendidos voláteis de $120 \mathrm{~g} / \mathrm{L}$, 
sólidos dissolvidos totais de 3,7 g/L, sólidos dissolvidos voláteis 3,6 g/L e nitrogênio total Kjeldahl de $350 \mathrm{mg} / \mathrm{L}$.

Comparativamente, o valor de DQO da água residuária produzida no laboratório foi maior que o dos lotes coletados na usina porque a cana usada era uma variedade para consumo humano de caldo de cana in natura.

\subsection{Adaptação de biomassa mesofílica utilizada como inóculo em ASBBR operado em condições termofílicas}

A fase de adaptação do inóculo foi executada em várias etapas, aplicando-se estratégias operacionais que almejaram adaptar a biomassa concomitantemente à temperatura de $55{ }^{\circ} \mathrm{C}$ e à vinhaça, conforme visto no item 4.4, já que o inóculo utilizado era proveniente de um reator UASB, operado à $35^{\circ} \mathrm{C}$, tratando água residuária de um abatedouro de aves. Esse reator era submetido a taxas de carregamento orgânicas de, no máximo, 1,64 gDQO/L.d no local de origem.

Foi necessário tempo prolongado de adaptação da biomassa (50 dias), a fim de se permitir o desenvolvimento de uma comunidade microbiana capaz de aderir ao suporte físico, visto que, anteriormente, os microrganismos estavam associados em grânulos.

Os valores médios dos parâmetros físico-químicos monitorados durante o período de adaptação e partida do reator são apresentados na Tabela 5.2.

A primeira etapa da partida do reator, aproximadamente os primeiros 15 dias, foi monitorada somente com sólidos suspensos voláteis, pois foi um período necessário para descarte da biomassa não aderida ao suporte utilizado, em que se observou, no efluente, perda de aproximadamente 1,8 g/L de sólidos suspensos voláteis. As análises físico-químicas de monitoramento só foram realizadas após se observar diminuição de sólidos suspensos voláteis no efluente (para aproximadamente $0,7 \mathrm{~g} / \mathrm{L}$ ). 
Tabela 5.2- Parâmetros físico-químicos monitorados do afluente e efluente durante a fase de adaptação.

\begin{tabular}{lccc|ccc}
\hline Fase de adaptação & \multicolumn{3}{c|}{ Afluente } & \multicolumn{3}{c}{ Efluente } \\
\cline { 2 - 7 } \multicolumn{1}{c}{ Parâmetros } & $1,18 \pm 0,11(5)$ & 1,00 & 1,28 & $0,80 \pm 0,18(5)$ & 0,58 & 1,03 \\
\cline { 2 - 7 } & Média $\pm \mathrm{DP}(\mathrm{nc}) *$ & Mínimo & Máximo & Média $\pm \mathrm{DP}(\mathrm{nc})$ & Mínimo & Máximo \\
$\mathrm{AB}(\mathrm{mg} \mathrm{CaCO} / \mathrm{L})$ & $571 \pm 332,3(15)$ & 5,5 & 956,3 & $369 \pm 309(15)$ & 0 & 771,2 \\
$\mathrm{AVT}(\mathrm{mgHAc} / \mathrm{L})$ & $76,2 \pm 64,1(15)$ & 11,8 & 241,8 & $308,2 \pm 113,7$ & 84,0 & 488,2 \\
$\mathrm{pH}$ & $7,96 \pm 0,65(15)$ & 5,92 & 8,6 & $6,87 \pm 1,10$ & 5,08 & 8,24 \\
$\mathrm{AI} / \mathrm{AP}$ & & & & $0,55 \pm 0,44$ & 0 & 1,25 \\
$\mathrm{ST}(\mathrm{mg} / \mathrm{L})$ & $2965 \pm 2029(5)$ & 1600 & 5296 & $1336 \pm 528(5)$ & 783 & 2100 \\
$\mathrm{SV}(\mathrm{mg} / \mathrm{L})$ & $1962 \pm 1985(5)$ & 318 & 4168 & $673 \pm 617(5)$ & 43 & 1125 \\
\hline
\end{tabular}

* DP - desvio padrão; nc - números de ciclos analisados.

Os resultados da fase de adaptação do inóculo mesofílico $\left(35^{\circ} \mathrm{C}\right)$ às condições termofílicas $\left(55^{\circ} \mathrm{C}\right)$ no ASBBR tratando a vinhaça, estão apresentados na Figura 5.1.

Até o $21^{\circ}$ ciclo, a carga orgânica aplicada em DQO por volume de reator e por tempo de ciclo era de 1,0 g/L.d e o reator era operado a $35{ }^{\circ} \mathrm{C}$ (Figura 5.1a). A partir deste ciclo, a temperatura foi aumentada repentinamente para $55^{\circ} \mathrm{C}$, pois a eficiência de remoção de DQO, aproximadamente $30 \%$, ainda estava aquém da esperada.

O reator UASB termofílico avaliado por Souza et al. (1992) levou 50 dias para alcançar condição operacional regular em COV de 0,2 a 1,0 gDQO/L.d em termos de produção de biogás, o que significou adaptação do inóculo que era constituído de dejetos de bovinos e lodo de estação de tratamento de esgoto. Mas, em geral, o tempo de adaptação de reatores mesofílicos também é grande.

A adaptação de um reator híbrido termofílico $\left(55^{\circ} \mathrm{C}\right)$ inoculado com lodo mesofílico granular e esmagado que foi retirado de um digestor que tratava águas residuárias de uma indústria processadora de batata levou aproximadamente 112 dias para se aclimatar em condições termofílicas (PENDER et al., 2004). 


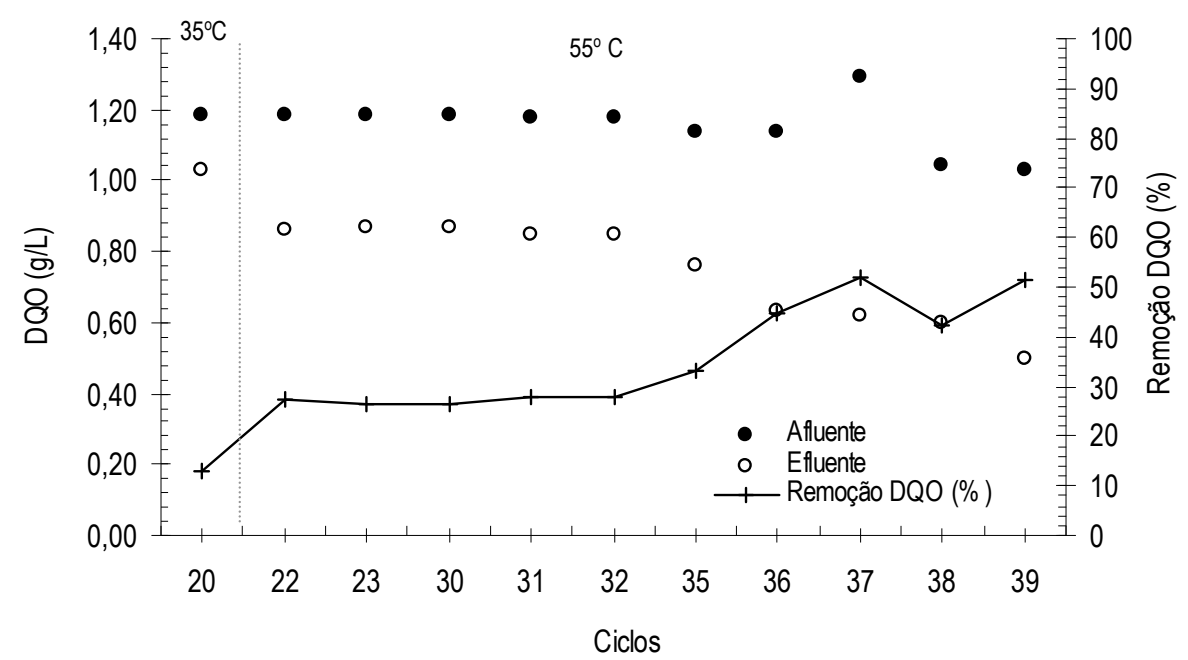

(a)

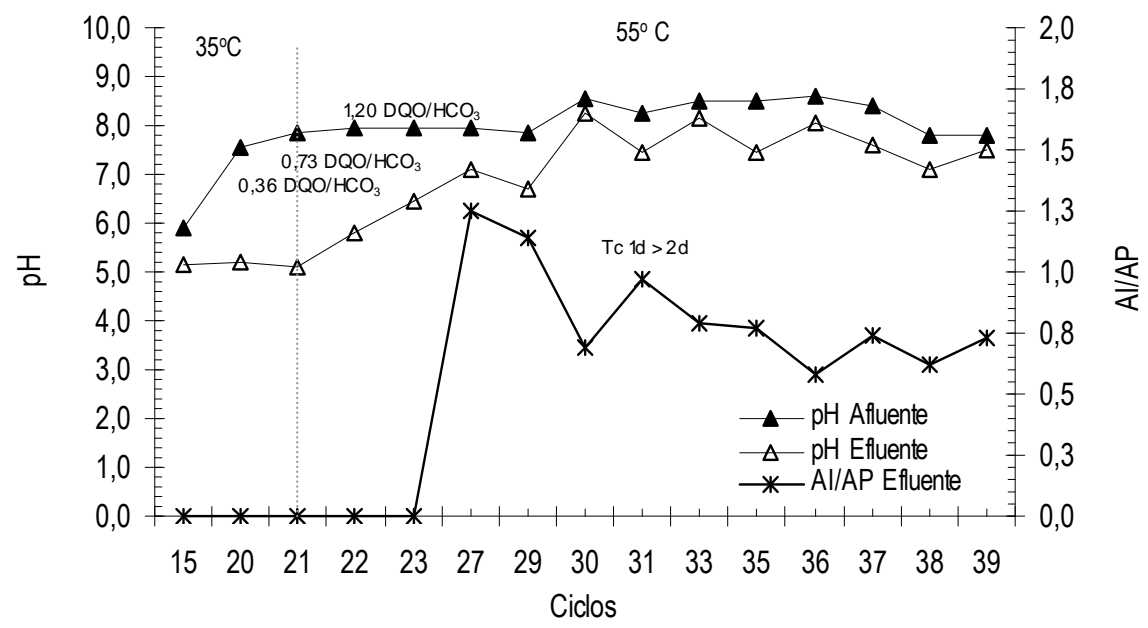

(b)

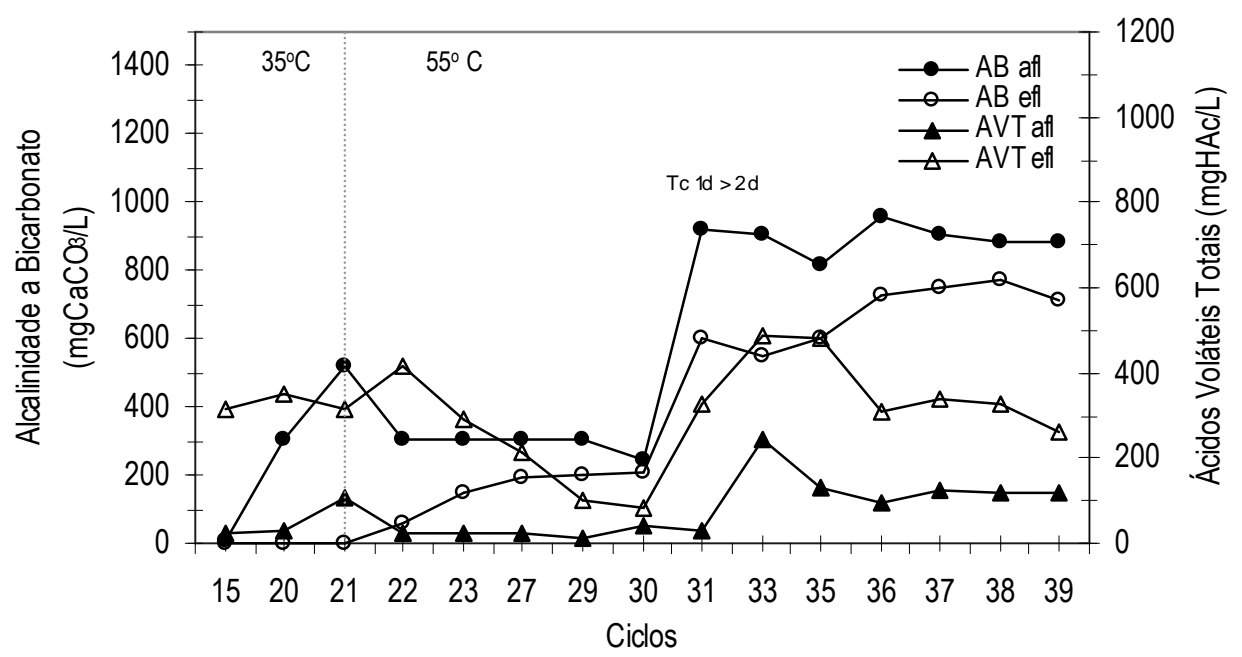

(c)

Figura 5.1 - Fase de adaptação da biomassa mesofílica a condições termofílicas: (a) DQO do afluente e efluente e remoção de DQO efluente; (b) pH e relação alcalinidade intermediária/alcalinidade parcial (AI/AP) do efluente e (c) alcalinidade a bicarbonato e ácidos voláteis totais afluente e efluente. 
Carmo (2004) avaliou duas formas de adaptar o inóculo mesofílico para temperatura de operação de $57{ }^{\circ} \mathrm{C}$ em um reator UASB tratando efluente sintético de polpa celulósica, aumentando-se subitamente de 35 para $57{ }^{\circ} \mathrm{C}$ e gradualmente a temperatura de 35 a $57{ }^{\circ} \mathrm{C}$. Nesse último caso, o tempo necessário para atingir a temperatura de operação desejada foi de aproximadamente 280 dias, durante o qual o reator apresentou eficiência de remoção de DQO variando de 3 a 35\%. Contudo, a autora avaliou como positiva a estratégia adotada de aumentar subitamente a temperatura do reator para $57{ }^{\circ} \mathrm{C}$. Nos primeiros 20 dias, as eficiências de remoção de DQO variaram de 28 a $48 \%$, concentração de ácidos graxos voláteis no efluente de 64 a $84 \mathrm{mg} / \mathrm{L}$ e porcentagem de metano de $40 \%$, sendo que a DQO afluente era de 492 a 609 $\mathrm{mg} / \mathrm{L}$ e tempo de detenção hidráulica de 40 horas.

Para facilitar a adaptação da biomassa à nova temperatura e evitar colapso do sistema devido à maior produção de ácidos orgânicos pela decomposição da matéria orgânica em maior temperatura, a COV foi diminuída para 0,5 gDQO/L.d, aumentandose o tempo de ciclo de 1 para 2 dias (Figura 5.1b). Após verificar tendência de estabilidade na remoção de DQO (cerca de 30\%) no ciclo 31, foram adicionados sais minerais, conforme soluções minerais propostas por Del Nery (1987) e, a partir do ciclo $\left(34^{\circ}\right)$, obteve-se a recuperação gradativa do sistema, que atingiu $55 \%$ de remoção de DQO no $37^{\circ}$ ciclo.

Destaque-se que foram adotadas linhas contínuas dos gráficos para demonstrar a tendência dos parâmetros avaliados. Essas linhas, no entanto, não representam análises do afluente e efluente de um sistema de tratamento contínuo e sim de ciclos distintos, porém consecutivos de um reator em regime descontínuo, em batelada.

Não foi observada queda de pH após mudança da temperatura (Figura 5.1b) e sim aumento progressivo, pois foi adotada uma estratégia de suplementação de bicarbonato para garantir alcalinidade suficiente ao sistema, de $0,36 \mathrm{gHCO}_{3}{ }^{-} / \mathrm{gDQO}\left(20^{\circ}\right.$ ciclo), 0,73 $\mathrm{gHCO}_{3}{ }^{-} / \mathrm{gDQO}\left(21^{\mathrm{o}}\right.$ ciclo), 1,20 $\mathrm{gHCO}_{3}{ }^{-} / \mathrm{gDQO}\left(22^{\circ}\right.$ ciclo). Esta última dose foi mantida nos ciclos subseqüentes da adaptação e partida do reator. Uma pequena queda de $\mathrm{pH}$, de 7,1 para 6,7, foi observada no ciclo 29 e após aumento de COV, houve oscilações de 7,1 a 8,2 , que não se distanciaram dos limites de $\mathrm{pH}$ para processos anaeróbios, que está entre 6,8 e 7,4 (SPEECE, 1996).

A relação AI/AP indica ocorrência de distúrbios no processo, como o desbalanceamento na produção e consumo de ácidos voláteis. Ripley et al. (1986) observaram estabilidade de seu sistema quando esta relação estava próxima a 0,3. 
Observou-se que, após suplementação de 1,20 $\mathrm{g} \mathrm{HCO}_{3}{ }^{-} / \mathrm{g} \mathrm{DQO}$, adição de minerais e manutenção da COV a partir do ciclo 34, esta relação tendeu a diminuir de 1,3 (ciclo 27) para 0,6 (ciclo 38) (Figura 5.1b).

Com o aumento da temperatura para $55{ }^{\circ} \mathrm{C}$ e da relação de $\mathrm{HCO}_{3}{ }^{-} / \mathrm{DQO}$ para 1,20, observou-se queda no acúmulo de ácidos voláteis e início da produção de alcalinidade a bicarbonato no efluente, desde o ciclo 22 ao 30 (Figura 5.1c), indicando que o sistema iniciava a dar indícios de adaptação às características da água residuária.

As morfologias encontradas no inóculo e na biomassa aderida ao meio suporte, após a fase de adaptação a $55^{\circ} \mathrm{C}$, coletadas no $39^{\circ}$ ciclo, estão apresentados nas Figuras $5.2,5.3$ e 5.4 .

O lodo anaeróbio do reator UASB (utilizado como inóculo), que tratava despejos de abatedouro de aves, apresentava abundante diversidade de microrganismos. Esta é uma característica essencial, que confere ao lodo a possibilidade de utilizá-lo como inóculo para outros reatores anaeróbios tratando diversos tipos de resíduos. Nesse inóculo, foram observadas morfologias microbianas como bacilos de diversas formas (bastões, curvos e delgados, cocóides, etc), cocos agrupados, filamentos longos e delgados agrupados semelhantes a células de arquéias Methanosaeta e morfologias semelhantes a células de Methanosarcina, que apresentam fluorescência ao serem observadas ao microscópio sob contraste de fase (Figura 5.2).

$\mathrm{Na}$ fase de partida do reator, ainda em condições mesofílicas (etapa iii, ciclo 21) a $35^{\circ} \mathrm{C}$, foi observada a redução da diversidade de morfologias. Nas amostras da superfície do reator, houve predominância de bacilos pequenos (Figura 5.3a), cocos e bastonetes (Figura 5.3b). As mesmas formas foram observadas no meio e fundo do reator, além de poucos filamentos de tamanhos maiores e estruturas semelhantes a leveduras, provavelmente remanescentes do processamento de fermentação do álcool (indicado pela seta da Figura 5.3c). 


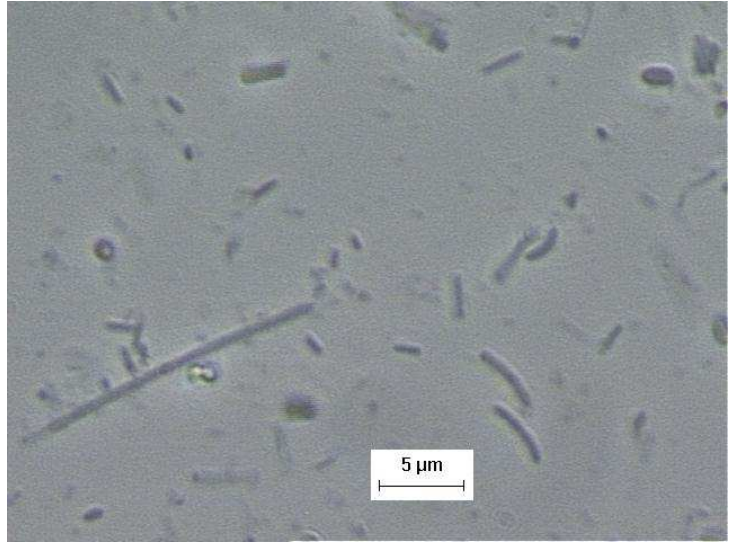

(a)

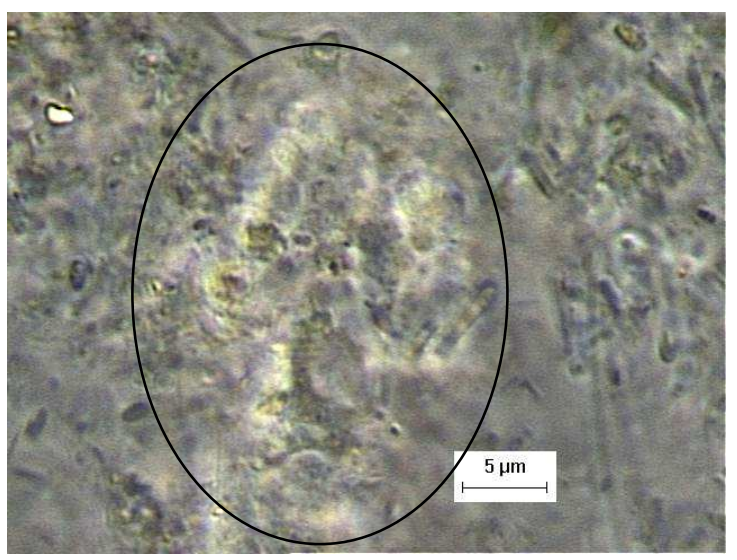

(c)

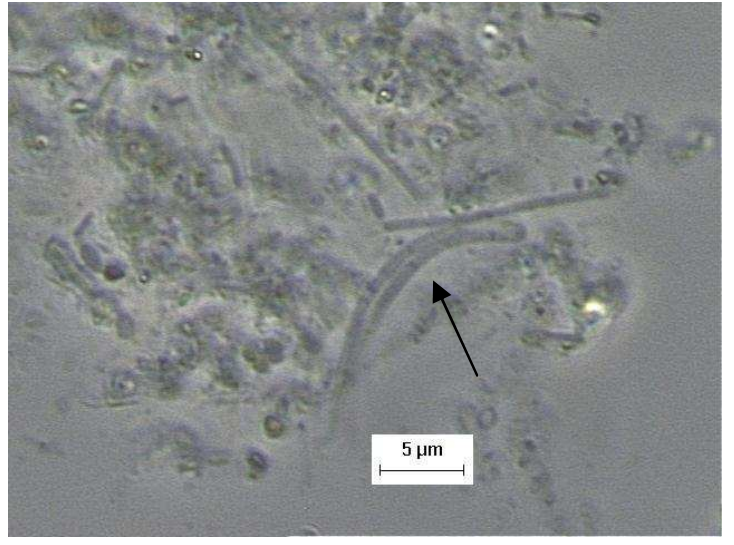

(b)

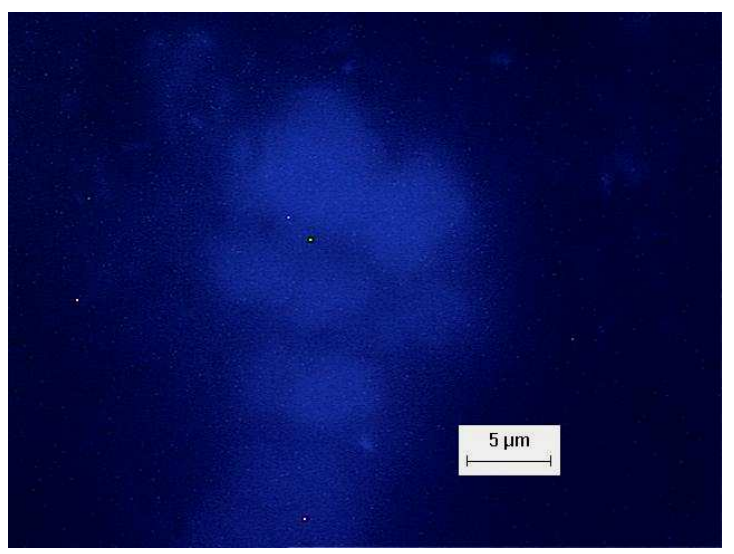

(d)

Figura 5.2 - Morfologias observadas no inóculo em microscópio óptico com aumento de 1500X: (a) diversidade de bacilos, (b) estruturas semelhante células de Methanosaeta em meio a bacilos e cocos (c) morfologia semelhante a células Methanosarcina e (d) fluorescência de c. 


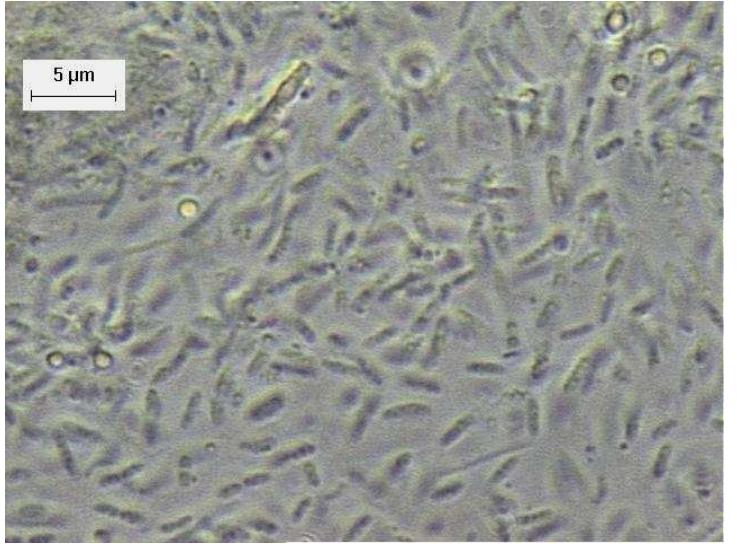

(a)

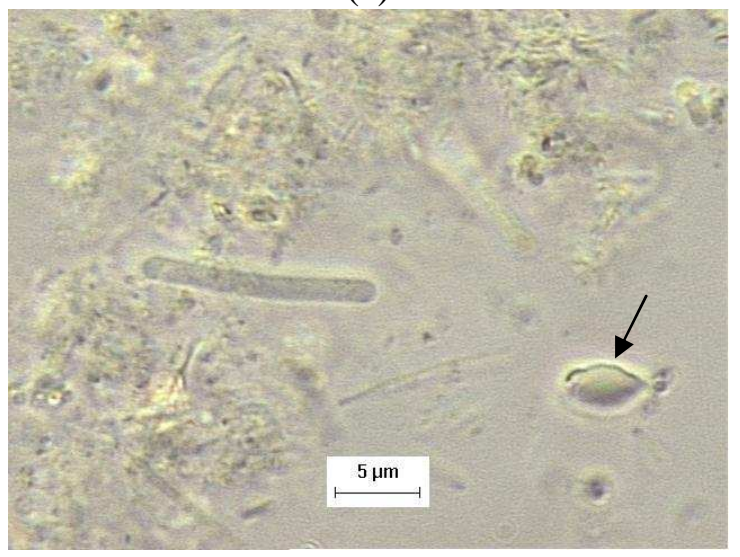

(c)

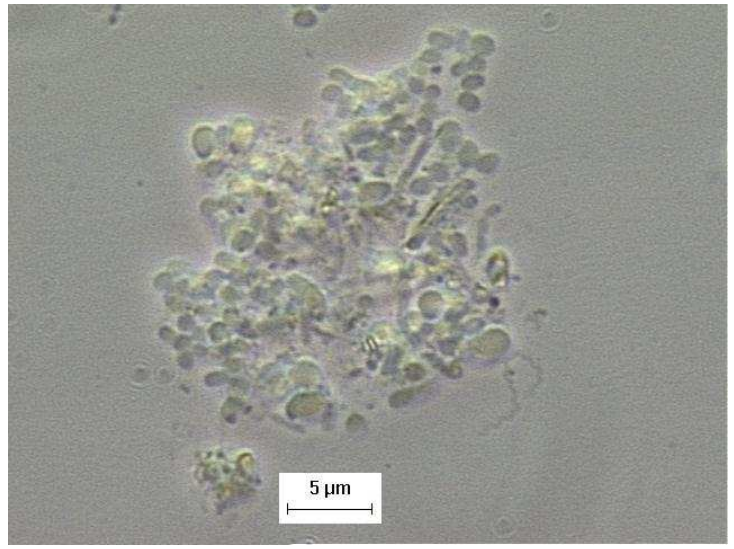

(b)

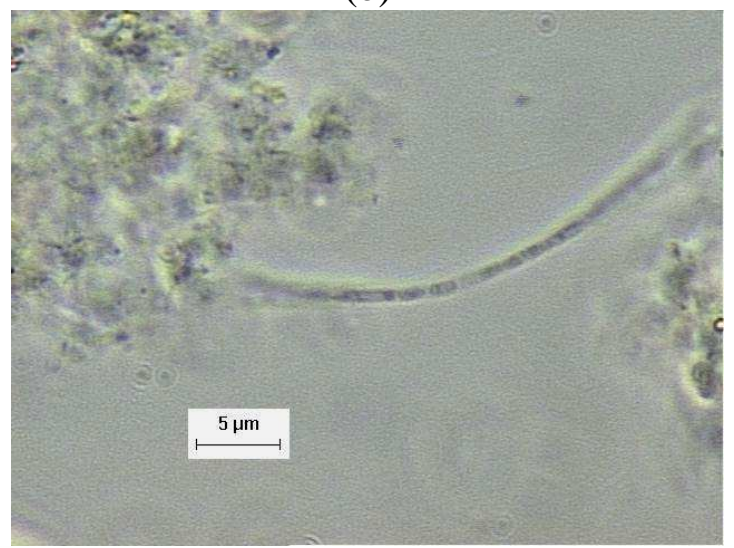

(d)

Figura 5.3 - Morfologias observadas na biomassa do reator ao final da fase mesofílica $\left(35^{\circ} \mathrm{C}\right)$ em microscópio óptico com aumento de 1500X: (a) bacilos em amostras da superfície do reator, (b) bacilos arredondados e cocos, (c) morfologias maiores provavelmente levedura (seta), (d) filamento.

Na etapa $v$, ciclo 30 , após 9 ciclos, já em condições termofílicas a $55^{\circ} \mathrm{C}$, foi observada a redução da diversidade de morfologias de microrganismos que pode ser atribuída à falta de suplementação de minerais da vinhaça afluente, aliado ao aumento da temperatura. Provavelmente, os nutrientes disponíveis na vinhaça, especialmente os metais traço (como $\mathrm{Ni}, \mathrm{Co}, \mathrm{Se}, \mathrm{Fe}, \mathrm{Ca}$ ), não eram suficientes para o bom desenvolvimento da biomassa anaeróbia até essa fase de adaptação. Ao longo do reator, foram observados alguns tipos de bacilos, filamentos e formas semelhantes a células de Methanosarcina.

Então, a partir da etapa vi, ciclo 34, iniciou-se a suplementação de macro e micro nutrientes para assegurar condições nutricionais fundamentais ao desenvolvimento da biomassa anaeróbia e, portanto, ao bom funcionamento do sistema de tratamento da vinhaça.

Após 15 ciclos da suplementação de minerais (final da etapa vi, ciclo 39), observou-se aumento da quantidade de leveduras, de bacilos e de morfologias 
semelhantes a células de Methanosaeta, algumas das quais, presentes na superfície do reator, apresentavam vacúolos de gases. No interior do reator, além das formas observadas na superfície, observou-se, entre as metanogênicas, a predominância de estruturas semelhantes à Methanosarcina fluorescentes. A presença de um material inerte precipitado na biomassa, também fluorescente, indicou o acúmulo de estruturas cristalinas (possivelmente de enxofre, potássio ou outro elemento) entre os poros do material suporte. Este tipo de material que brilhava sob a incidência de luz ultravioleta se tratava de um cristal ou de outro material abiótico. No fundo do reator, foram observados bacilos fluorescentes, bacilos delgados, leveduras, células semelhantes à Methanosaeta, bacilos curvos semelhantes a bactérias redutoras de sulfato (Figura 5.4e).

A presença de bactérias redutoras de sulfato foi estimulada devido à quantidade de sulfato afluente (cerca de $38 \mathrm{mg} / \mathrm{L}$ na concentração de vinhaça como DQO de 1,0 g/L), que pode advir da adição de ácido sulfúrico nas dornas de fermentação para ajustar o pH para as leveduras Saccharomyces cereavisae utilizadas na fermentação para produção de álcool.

Nesta última etapa, observou-se que a diversidade microbiana havia aumentado significativamente, devido à suplementação de minerais e ao aumento para a temperatura de trabalho, indicando que o sistema poderia ser considerado como adaptado a $55^{\circ} \mathrm{C}$ e que os microrganismos estavam aptos para degradar a vinhaça nessas condições. 


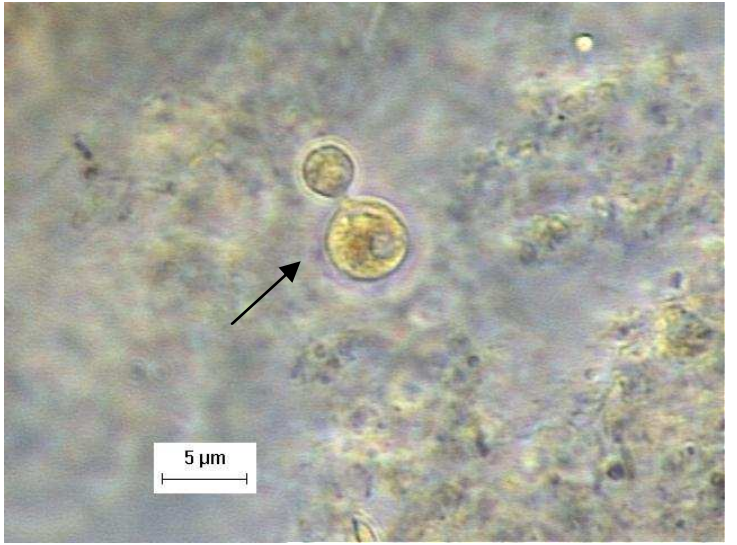

(a)

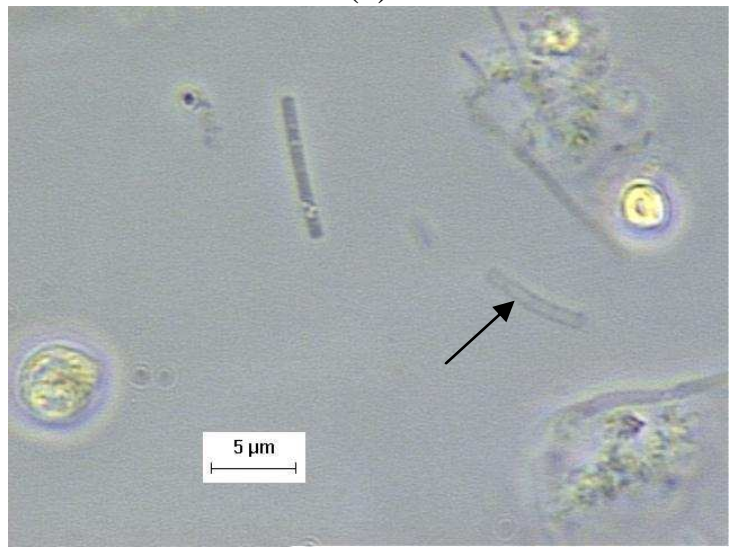

(c)

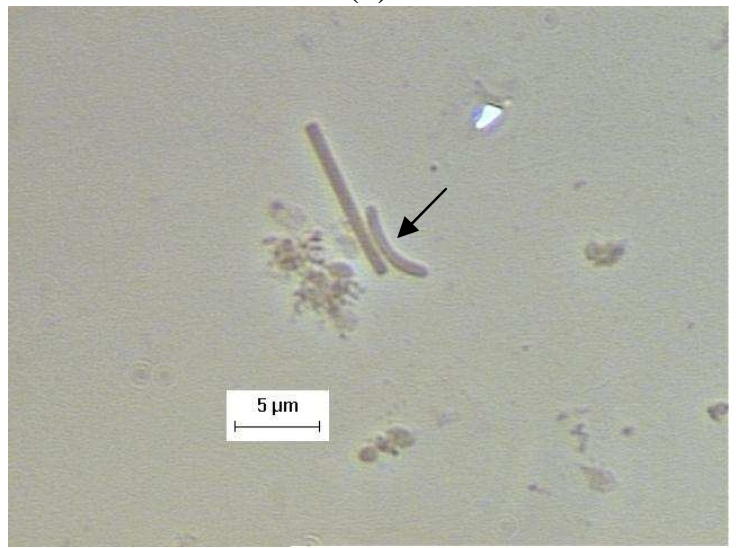

(e)

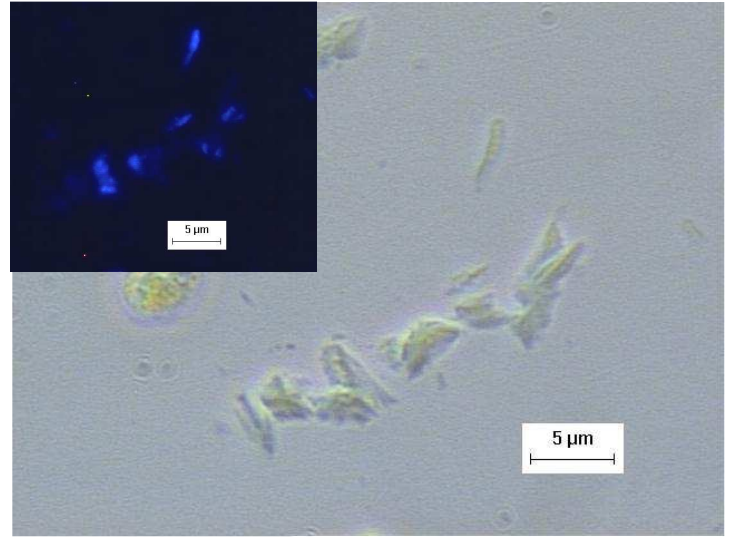

(b)

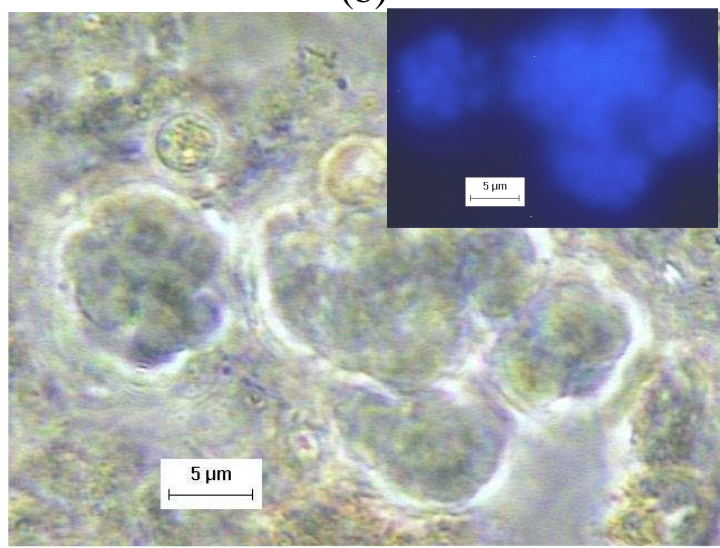

(d)

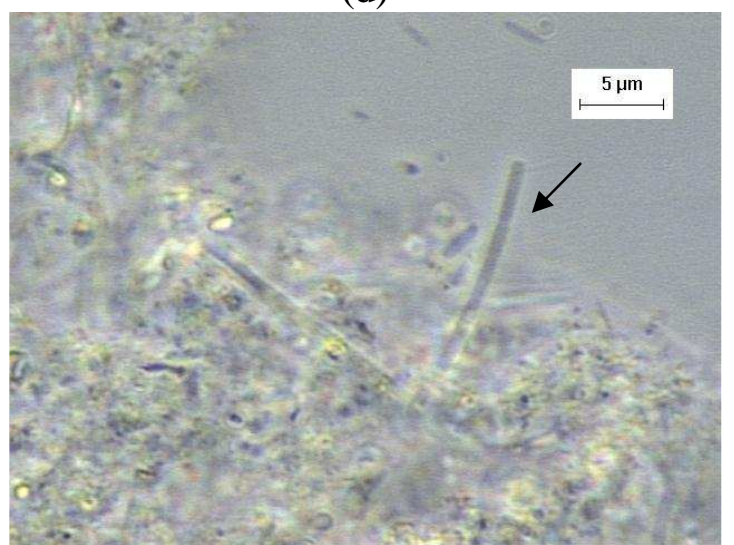

(f)

Figura 5.4 - Morfologias observadas na biomassa do reator ao final da fase de adaptação em condições termofílicas $\left(55^{\circ} \mathrm{C}\right)$ em microscópio óptico com aumento de 1500X: (a) levedura em brotação, (b) cristais e em detalhe a foto em fluorescência, (c) morfologias semelhantes a célula de Methanosaeta com vacúolos (seta), (d) estrutura semelhante a células de Methanosarcina e em detalhe a foto em fluorescência, (e) possível Methanosaeta e bactéria redutora de sulfato, bacilos curvos (seta) e (f) Methanosaeta e bacilos.

Com base nos resultados obtidos durante o monitoramento do período de adaptação da biomassa às condições termofílicas, concluiu-se ser possível utilizar o lodo de reator UASB mesofílico aplicado ao tratamento de águas residuárias de abatedouro 
de aves como inóculo do reator anaeróbio operado em bateladas seqüenciais. O lodo apresentou boa capacidade de adaptação, pois a diversidade de microrganismos do inóculo proporcionou a seleção da população microbiana com potencial metabólico capaz de se desenvolver sob condições termofílicas, a partir da adição de nutrientes e de bicarbonato no afluente. O bicarbonato foi adicionado para aumentar a capacidade tampão do sistema de neutralização dos ácidos formados no início do funcionamento com baixa carga orgânica volumétrica. A adição de nutrientes ( $34^{\circ}$ ciclo) foi essencial, pois os metais traços provavelmente não estavam disponíveis na vinhaça e são imprescindíveis para o desenvolvimento dos microrganismos anaeróbios, especialmente metanogênicos.

\subsection{Desempenho do reator anaeróbio termofílico $\left(55^{\circ} \mathrm{C}\right)$ operado em batelada seqüencial contendo biomassa imobilizada com aumento gradativo de carga orgânica}

A partir da consideração de que o reator estava adaptado às condições termofílicas com COV 0,5 g/L.d (concentração 1,0 gDQO/L e tempo de ciclo 2 dias) em que apresentou maior diversidade de microrganismos, aumento de alcalinidade a bicarbonato efluente, diminuição de AVT, estabilidade de pH e remoção de DQO razoável de aproximadamente 50\%, iniciou-se aumento gradativo da carga orgânica, aplicando-se afluente mais concentrado (menos diluído). Com esta finalidade, o reator foi submetido à COV de aproximadamente 1,0 a 5,0 gDQO/L.d, com aumento da concentração teórica de vinhaça de $1,0 \mathrm{~g} / \mathrm{L} ; 2,5 \mathrm{~g} / \mathrm{L} ; 5,0 \mathrm{~g} / \mathrm{L} ; 10,0 \mathrm{~g} / \mathrm{L} ; 20,0 \mathrm{~g} / \mathrm{L}$ e novamente $10,0 \mathrm{~g} / \mathrm{L}\left(\mathrm{t}_{\mathrm{c}} 2 \mathrm{~d}\right)$ em sete fases consecutivas. A partir da fase II com COV de 2,5 g/L.d, foi necessário aumentar o tempo de ciclo de acordo com a carga orgânica aplicada nas fases seguintes para garantir eficiência de remoção de DQO de pelo menos $60 \%$.

\subsubsection{Desempenho do reator em batelada em COV de 1,0 gDQO/L.d (fase I) e 2,5 gDQO/L.d (fase II)}

A fase I teve a duração 8 dias, sendo a COV de 1,0 g DQO/L.d e tempo de ciclo de 1 dia (ciclo 40 a 48). Na fase II, a COV foi aumentada para 2,5 gDQO/L.d, aplicando-se esse valor por 22 dias (ciclo 49 a 70). 
Na Tabela 5.3 e 5.4, encontram-se resultados de alguns parâmetros monitorados durante as fases experimentais I e II, respectivamente.

Com o aumento da COV para 1,0 e 2,5 g/L.d, foi observado simultaneamente aumento da eficiência do reator em média de $43 \%$ para $72 \%$, respectivamente. Pode-se concluir que os valores aplicados de carga orgânica (de 0,5 g/L.d na fase de adaptação e e de 1,0 g/L.d. na fase I) eram inferiores ao que poderiam ser aplicados, ou seja, o potencial de degradação da biomassa desenvolvida no reator era superior à cargas orgânicas aplicadas.

Tabela 5.3 - Parâmetros físico-químicos monitorados do afluente e efluente da fase I.

\begin{tabular}{lccc|ccc}
\hline \multirow{2}{*}{ Fase I - COV 1,0 gDQO/L.d - 1,0 gDQO/L } & \multicolumn{3}{c}{ Efluente } \\
\cline { 2 - 7 } Parâmetros & \multicolumn{3}{c}{ Afluente } & \multicolumn{3}{c}{} \\
\cline { 2 - 7 } & Média \pm DP (nc)* & Mínimo & Máximo & Média \pm DP $(\mathrm{nc})$ & Mínimo & Máximo \\
\hline $\mathrm{AB}(\mathrm{mg} \mathrm{CaCO} / \mathrm{L})$ & $0,85 \pm 0,04(4)$ & 0,81 & 0,90 & $0,48 \pm 0,05(4)$ & 0,42 & 0,52 \\
$\mathrm{AVT}(\mathrm{mgHAc} / \mathrm{L})$ & $214,3 \pm 78,2(4)$ & 803,9 & 994,7 & $958,9 \pm 98,1(4)$ & 816,6 & 1041,7 \\
$\mathrm{pH}$ & $8,37 \pm 0,18(4)$ & 136,4 & 295,0 & $223,9 \pm 59,1(4)$ & 156,5 & 288,8 \\
$\mathrm{AI} / \mathrm{AP}$ & & & 8,52 & $8,28 \pm 0,16$ & 8,12 & 8,50 \\
$\mathrm{ST}(\mathrm{mg} / \mathrm{L})$ & $2059 \pm 323(4)$ & 1722 & 2400 & $1303 \pm 420(4)$ & 753 & 1643 \\
$\mathrm{SV}(\mathrm{mg} / \mathrm{L})$ & $964 \pm 319(4)$ & 661 & 1400 & $559 \pm 97(4)$ & 431 & 667 \\
\hline
\end{tabular}

* DP - desvio padrão; nc - números de ciclos analisados.

Observou-se ligeiro acréscimo dos valores médios obtidos de alcalinidade a bicarbonato do afluente ao efluente (Tabela 5.3) e pH efluente acima de 8,0 e foi devido a este fato que a suplementação de bicarbonato na entrada foi diminuída de 1,2 para 0,8 $\mathrm{HCO}_{3}{ }^{-} / \mathrm{DQO}$ (fase II).

Ainda assim, o pH do efluente da fase II se manteve próximo a 8,0 $(7,91 \pm 0,60)$ conforme pode ser visto na Tabela 5.4.

Observou-se também que o valor de sólidos voláteis no efluente aumentou de $559 \pm 97 \mathrm{mg} / \mathrm{L}$ para $889 \pm 252 \mathrm{mg} / \mathrm{L}$ com o aumento de carga orgânica de 1,0 para 2,5 $\mathrm{g}$ DQO/L.d, que pode ser devido maior perda de biomassa do interior do reator que sai junto com o efluente ou devido ao aumento da produção de SV devido ao aumento na concentração de carga orgânica no afluente. 
Tabela 5.4 - Parâmetros físico-químicos monitorados do afluente e efluente da fase II.

Fase II - COV 2,5 gDQO/L.d - 2,5 gDQO/L

\begin{tabular}{llll|lll}
\hline \multirow{2}{*}{ Parâmetros } & \multicolumn{3}{c|}{ Afluente } & \multicolumn{3}{c}{ Efluente } \\
\cline { 2 - 7 } & Média $\pm \mathrm{DP}(\mathrm{nc}) *$ & Mínimo & Máximo & Média $\pm \mathrm{DP}(\mathrm{nc})$ & Mínimo & Máximo \\
\hline $\mathrm{DQO}(\mathrm{g} / \mathrm{L})$ & $2,54 \pm 0,33(3)$ & 2,16 & 2,74 & $0,69 \pm 0,12(3)$ & 0,57 & 0,81 \\
$\mathrm{AB}(\mathrm{mg} \mathrm{CaCO} / \mathrm{L})$ & $1453,4 \pm 54,5(3)$ & 1390,4 & 1484,8 & $1760,8 \pm 77(3)$ & 1672 & 1810,6 \\
$\mathrm{AVT}(\mathrm{mgHAc} / \mathrm{L})$ & $410,5 \pm 65(3)$ & 373 & 485,6 & $219 \pm 95,2(3)$ & 132,2 & 320,8 \\
$\mathrm{pH}$ & $7,39 \pm 0,09(3)$ & 7,34 & 7,5 & $7,91 \pm 0,6(3)$ & 7,4 & 8,53 \\
$\mathrm{AI} / \mathrm{AP}$ & & & & $0,36 \pm 0,05$ & 0,32 & 0,42 \\
$\mathrm{ST}(\mathrm{mg} / \mathrm{L})$ & $3687 \pm 301(3)$ & 3474 & 3900 & $2861 \pm 98(3)$ & 2750 & 2933 \\
$\mathrm{SV}(\mathrm{mg} / \mathrm{L})$ & $1382 \pm 167(3)$ & 1263 & 1500 & $889 \pm 252(3)$ & 600 & 1067 \\
\hline
\end{tabular}

* DP - desvio padrão; nc - números de ciclos analisados.

As Figuras 5.5 e 5.6 mostram os perfis de DQO e de eficiência de remoção e de consumo de ácidos orgânicos, respectivamente, realizados ao longo de uma batelada da fase I, na condição experimental de 1,0 gDQO/L.d no $48^{\circ}$ ciclo desde a inoculação. O perfil foi realizado quando o reator já apresentava estabilidade dinâmica aparente, conforme observado em 4 amostragens realizadas durante 9 ciclos em que o reator estava sendo operado sob essas condições.

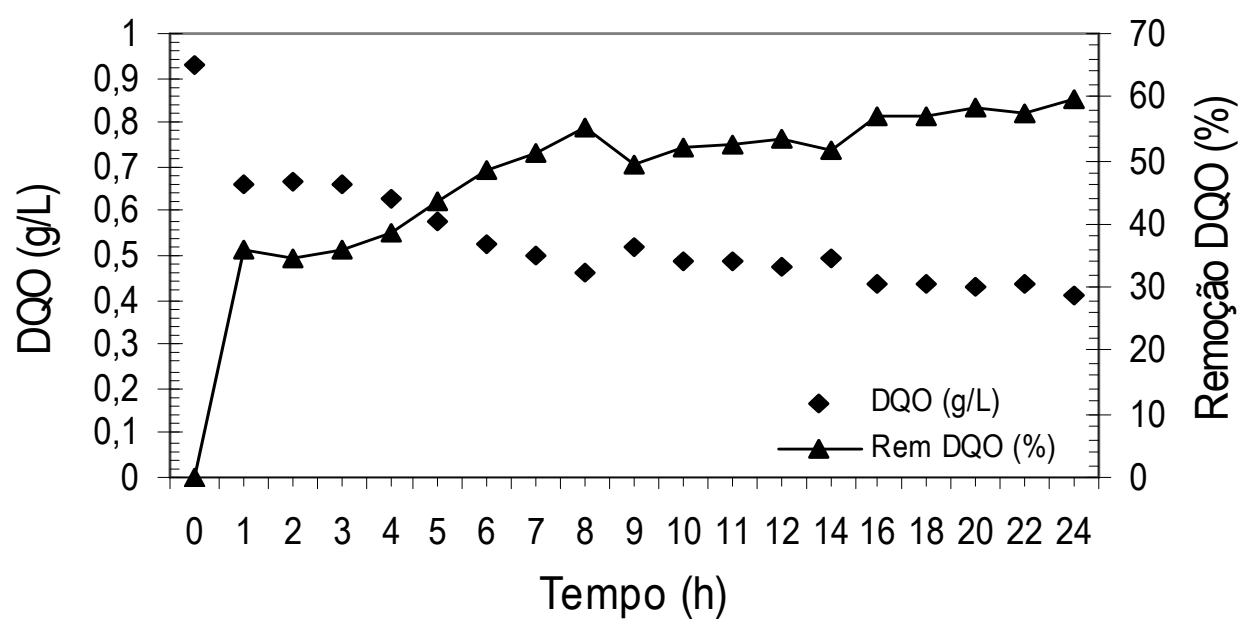

Figura 5.5 - Perfil de concentração de vinhaça, em DQO, ao longo do $48^{\circ}$ ciclo da fase I. 


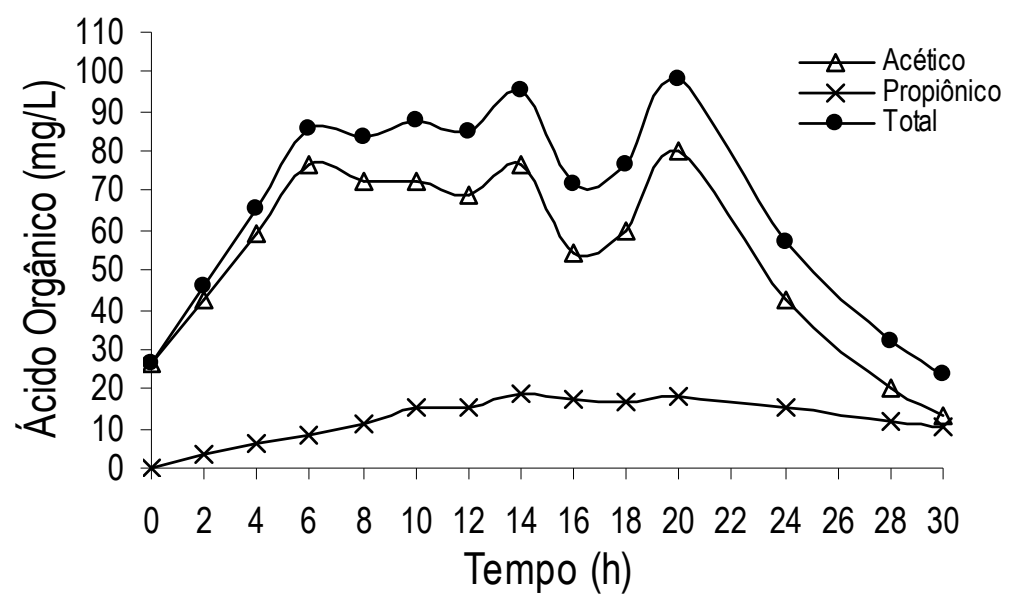

Figura 5.6 - Perfil de ácidos orgânicos ao longo do $48^{\circ}$ ciclo da fase I.

Logo na primeira hora da batelada, $35 \%$ da DQO de entrada foi degradada e, no intervalo de 1 a 8 horas, a eficiência já alcançava $55 \%$. A partir deste ponto, observouse pequeno aumento de eficiência, chegando a $60 \%$ ao final de 24 horas (Figura 5.5). Com base na remoção de DQO, 8 horas do ciclo seriam necessárias para reduzir pelo menos $50 \%$ da concentração inicial nessas condições.

A fase de produção de ácidos orgânicos se estendeu até 22 horas, chegando a $100 \mathrm{mg} / \mathrm{L}$ de ácidos orgânicos totais. O ácido acético foi o maior responsável pelos ácidos totais, mas o ácido propiônico produzido se acumulou ao longo da batelada, ainda que em concentração baixa (aproximadamente $10 \mathrm{mg} / \mathrm{L}$ ). Pelo perfil dos ácidos, supõe-se que nesse período houve atividade das arquéias acetoclásticas consumidoras de acetato (ex. Methanosaeta) devido ao declínio do ácido acético residual para concentração de 12,91 mg/L alcançado no último tempo de amostragem (30 h). O não consumo total do ácido pode estar relacionado com a falta de nutrientes no final do ciclo ou a limitações do processo termofílico.

A maior concentração de ácidos voláteis é uma das consequiências do desequilíbrio de processos anaeróbios termofílicos como citado por van Lier (1996).

Morfologias semelhantes a Methanosaeta foram observadas com freqüência em todos os pontos examinados do reator, conforme pode ser observado adiante na Tabela 5.10 .

Ao longo do perfil, foram detectados, em todas as amostragens por cromatografia gasosa, traços de fenol próximo ao limite de detecção, de aproximadamente $0,8 \mu \mathrm{g} / \mathrm{L}$. 
Após a estabilidade da segunda fase, em que a eficiência de remoção foi de cerca de $80 \%$, no $68^{\circ}$ ciclo também foram realizados os perfis ao longo de uma batelada de DQO e de eficiência de remoção, do consumo de ácidos orgânicos e da relação da porcentagem de metano e gás carbônico, que estão apresentados nas Figuras 5.7, 5.8 e 5.9, respectivamente. Nessa fase, o reator operou com carga orgânica volumétrica de 2,5 gDQO/L.d, há 22 ciclos consecutivos (do ciclo $49^{\circ}$ ao $70^{\circ}$ ).

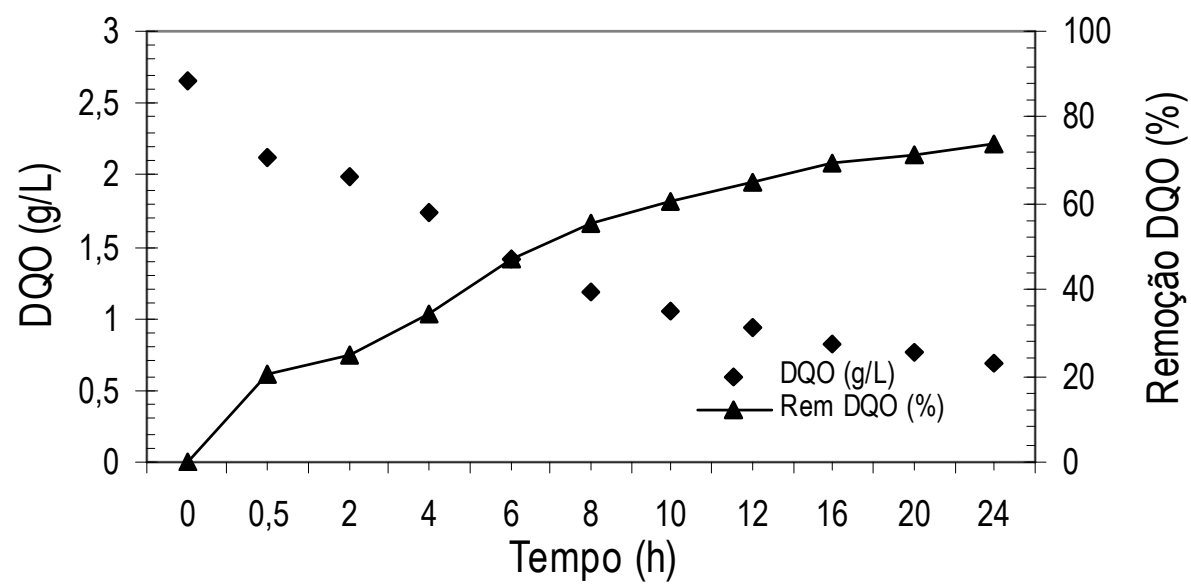

Figura 5.7 - Perfil de concentração de vinhaça ao longo do $68^{\circ}$ ciclo da fase II.

Em 30 minutos, observou-se queda acentuada da DQO, de $25 \%$ e, a partir de 12 horas, houve pequena variação na eficiência de remoção, de 65 a $70 \%$, apesar de crescente (Figura 5.7).

O maior acúmulo de ácidos orgânicos ocorreu entre 4 e 10 horas (Figura 5.8), indicando um possível desbalanceamento entre a produção e o consumo de ácidos, uma vez que, no sistema de degradação anaeróbia, esses processos devem ocorrer simultaneamente (embora seqüencialmente) em reatores anaeróbios estáveis.

Às 12 horas de ciclo, observou-se queda de ácido acético e acúmulo contínuo de ácido propiônico, que atingiu a concentração de $104 \mathrm{mg} / \mathrm{L}$ (16 horas). Mas, o consumo de ácido acético mostrou que as arquéias acetoclásticas ainda não sofriam inibição devido à presença cumulativa do ácido propiônico (Figura 5.8). O valor residual de ácido acético foi semelhante ao residual da fase I, sendo de $10,35 \mathrm{mg} / \mathrm{L}$ no tempo de amostragem 24 horas.

O acúmulo de ácidos orgânicos, especialmente ácido propiônico, em sistemas anaeróbios termofílicos foi relatado em diversos trabalhos. Ahring (1994) e van Lier (1995) atribuem o desbalanceamento entre a produção e o consumo de ácidos a 
distúrbios da população metanogênica que cresce mais lentamente que as populações hidrolíticas e fermentativas.

A degradação do propionato nos sistemas termofílicos é mais lenta do que os demais ácidos orgânicos encontrados em processos anaeróbios e, dentro dos sistemas termofílicos pode representar cerca de $66 \%$ da DQO total dos ácidos orgânicos voláteis (WIEGANT, 1986). Segundo Öztürk (1991), somente após as concentrações de ácidos butírico e acético serem consumidas, o ácido propiônico começa a ser degradado. Por isso também, há maiores concentrações de ácidos voláteis no efluente de reatores termofílicos e freqüente acúmulo de ácido propiônico que em reatores mesofílicos.

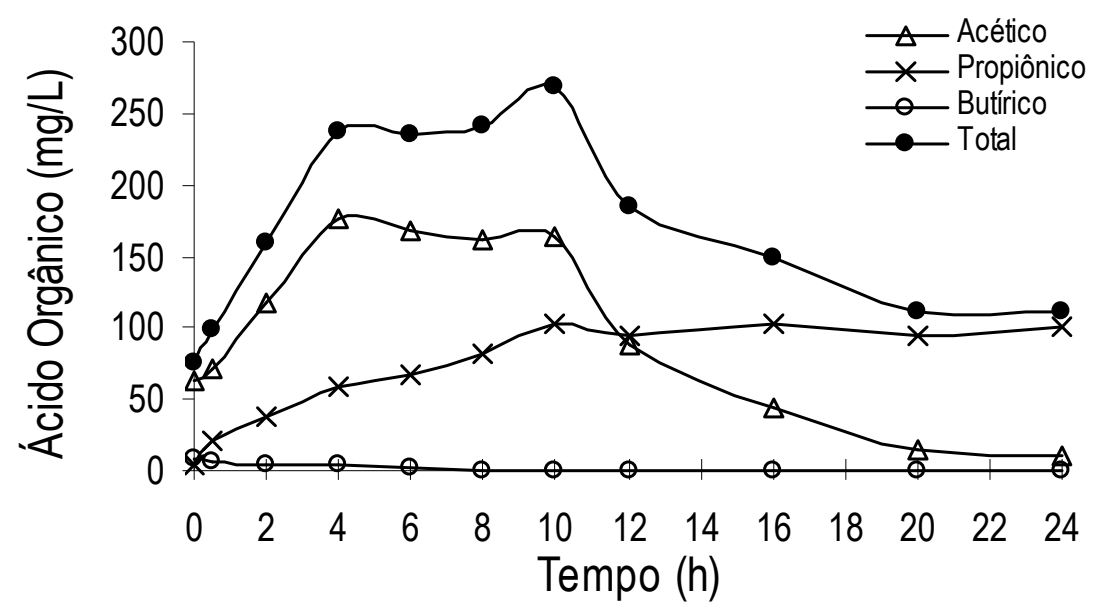

Figura 5.8 - Perfil de ácidos orgânicos ao longo do $68^{\circ}$ ciclo da fase II .

Uma possível causa para o acúmulo de ácido propiônico foi a perda da capacidade do sistema de converter o propionato em acetato, conversão esta realizada por populações acetogênicas. Os microrganismos consumidores de propionato (ex. Syntrophobacter wolinii) poderiam estar em pequeno número no inóculo. Esses microrganismos usam uma faixa muito limitada de substratos e têm baixa taxa de crescimento específico que limita sua atividade dentro do reator. Já as consumidoras de butirato (ex. Syntrophomnas wolfei) competem melhor porque têm alta taxa de crescimento específico e um espectro muito maior de substrato (GRIFFIN et al., 1998). Portanto, a ausência dos consumidores de propionato ou por estarem presentes em pequena quantidade no reator, pode provocar colapso do sistema pelo acúmulo do propionato não degradado.

Mosey (1983), em seu estudo de modelagem matemática dos mecanismos reguladores de formação de ácidos orgânicos voláteis a partir da glicose, discutiu o 
papel das bactérias acetogênicas na conversão do ácido propiônico e butírico em ácido acético. Harper \& Pohland (1986) apresentaram as relações termodinâmicas de dependência entre a pressão parcial de hidrogênio $\left(\mathrm{H}_{2}\right)$ e as reações acetogênicas do processo de digestão anaeróbia.

Segundo esses autores, as reações acetogênicas de propionato ou butirato a acetato são termodinamicamente desfavoráveis $\left(\Delta \mathrm{G}_{0}>0\right)$, sendo a energia livre de +76 kJ para conversão do proprionato a acetato (VAN LIER, 1995).

A conversão de propionato a acetato só é termodinamicamente favorável se a pressão parcial de $\mathrm{H}_{2}$ for inferior a $10^{-4}$ atm. Desse modo, o acúmulo de ácido propiônico indica que a produção de $\mathrm{H}_{2}$ foi maior do que seu consumo pelas arquéias hidrogenotróficas, uma vez que a conversão de acetato a metano é termodinamicamente favorável (- $31 \mathrm{~kJ})$, conforme relata van Lier (1995), e essa conversão não foi interrompida conforme pode ser observado na Figura 5.9.

Outra explicação possível sobre a presença cumulativa de ácido propiônico neste perfil temporal pode estar relacionada com uma possível falta de nutrientes no final do ciclo, que promove a paralisação do processo de conversão de ácidos orgânicos a metano.

Lopeza et al. (2006) destacou que, em muitos sistemas de tratamento biológico, o crescimento bacteriano e a quantidade de biomassa ativa são limitadas pela disponibilidade de substrato. Sob condições adversas de crescimento, processos endógenos têm uma significante influência na quantidade de biomassa ativa e, portanto, no desempenho total do sistema.

Por sua vez, a Figura 5.9 indica que a acidogênese e metanogênese foram realizadas até 12 horas. Neste período, a porcentagem de metano no biogás atingiu $62 \%$ dentre de todos os gases medidos.

A partir de 12 horas da batelada, o metano pode ter sido produzido em quantidade insuficiente para deslocar o líquido por pressão. 


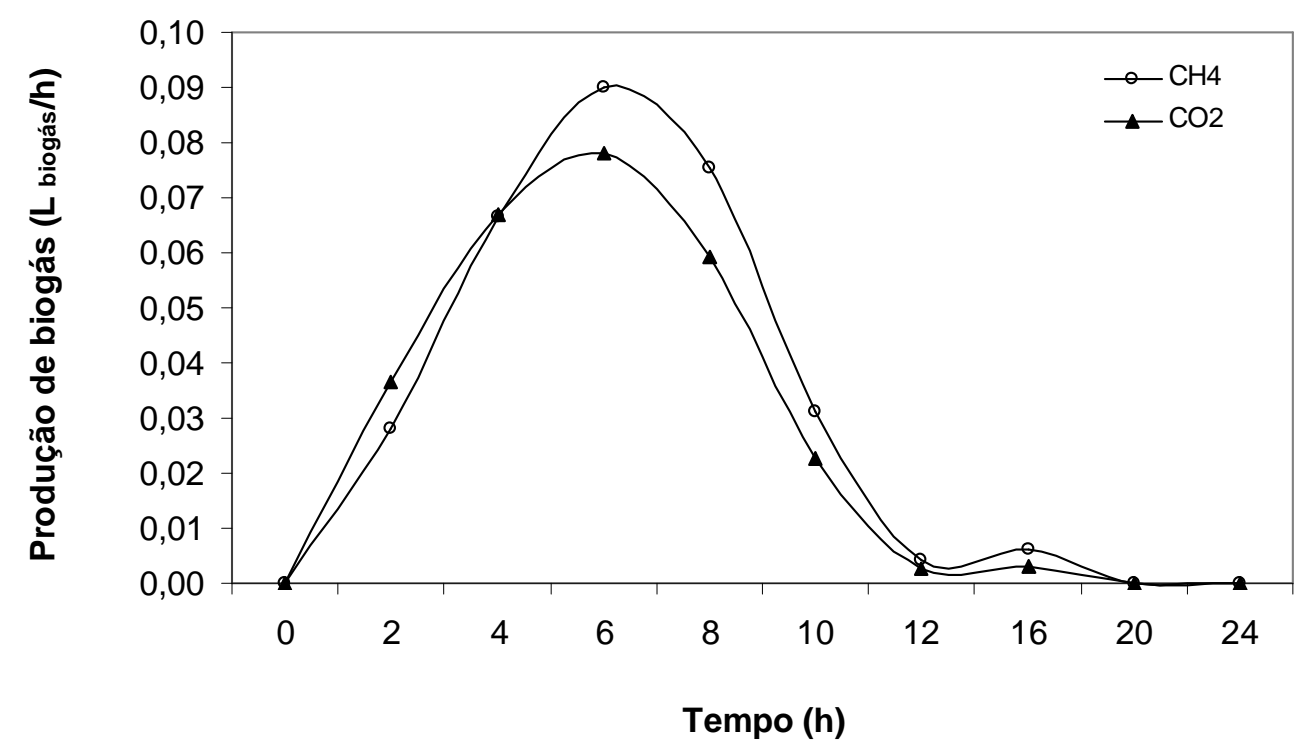

Figura 5.9 - Produção de $\mathrm{CH}_{4}$ e $\mathrm{CO}_{2}$ ao longo do $68^{\circ}$ ciclo da fase II.

Por cálculos, foi possível estimar que a batelada produziu cerca de $0,3 \mathrm{~L}$ de metano em 1 dia. $\mathrm{O}$ maior pico de produção de $\mathrm{CO}_{2}$ ocorreu em 7 horas, coincidindo com o perfil da fase metanogênica.

Quanto à determinação de fenol, observou-se que, na amostra retirada em 24 horas, havia 3,31 mg/L, e, nas demais amostras, apenas traços do composto foram detectados.

A Resolução CONAMA n. 357 (2006) estabelece os padrões de lançamento em corpos de água de efluentes com fenol total de no máximo $0,5 \mathrm{mg} / \mathrm{L}$. Sendo assim, o efluente do reator ainda necessitaria de um tratamento posterior para remoção de fenol residual e as análises de fenol por cromatografia deveriam ser feitas em um limite de detecção menor ao que foi analisado.

\subsubsection{Desempenho do reator em batelada em COV de 3,3 e 5,0 gDQO/L.d - fases III a VII}

Com o objetivo de se aumentar gradativamente a carga orgânica aplicada no reator termofílico, mudanças operacionais foram necessárias nas fases seguintes para assegurar condições adequadas para a biomassa, visando obter-se maior eficiência do reator, como maior tempo de ciclo para degradação da vinhaça e produção de alcalinidade. Portanto, perfis temporais prévios foram realizados logo após as mudanças de fases quanto à degradação de DQO, consumo de AVT, produção de $\mathrm{AB}$ e medição 
de $\mathrm{pH}$ nas fases III, IV, V e VII para comprovar se haveria necessidade de maior tempo de ciclo que o desejado, que era de 1 dia para as fases III e IV, em que o reator atingiria 5 e $10 \mathrm{gDQO} / \mathrm{L} . \mathrm{d}$, e de 2 dias para as demais fases (V, VI e VII) em que a COV atingida seria de 10 a 20 gDQO/L.d. Dessa forma, com os dados dos perfis prévios, seria obtido um tempo de ciclo suficiente, prevenindo possível inibição das metanogênicas que seguiriam atuando principalmente no final da batelada, como foi observado nos perfis das fases anteriores, e que garantisse patamares satisfatórios de eficiência de remoção da matéria orgânica da vinhaça, medida indiretamente como DQO de no mínimo $60 \%$. Esses perfis eram realizados após 3 ciclos de um dia, quando se mudavam as condições de cada fase.

A seguir, serão apresentados separadamente por fases, os dados destes perfis prévios e, em seguida, serão apresentados os dados de monitoramento, após se adotar, com base nesses perfis, um tempo de ciclo para cada concentração de vinhaça.

Com o estabelecimento do tempo de ciclo mais propício em cada fase, o monitoramento dos parâmetros físico-químicos de ciclos consecutivos permitiu definir o momento de mudança de fase de acordo com a eficiência de remoção de DQO.

\subsubsection{Operação do reator na fase III com 5,0 gDQO/L e COV 3,3 gDQO/L.d}

\section{Ajuste do tempo de ciclo da fase III pelo perfil temporal prévio}

O tempo do ciclo se estendeu de 1 até 3 dias (72 horas), a fim de se verificar o período em que ocorria a maior remoção de DQO de acordo com o perfil temporal apresentado na Figura 5.10.

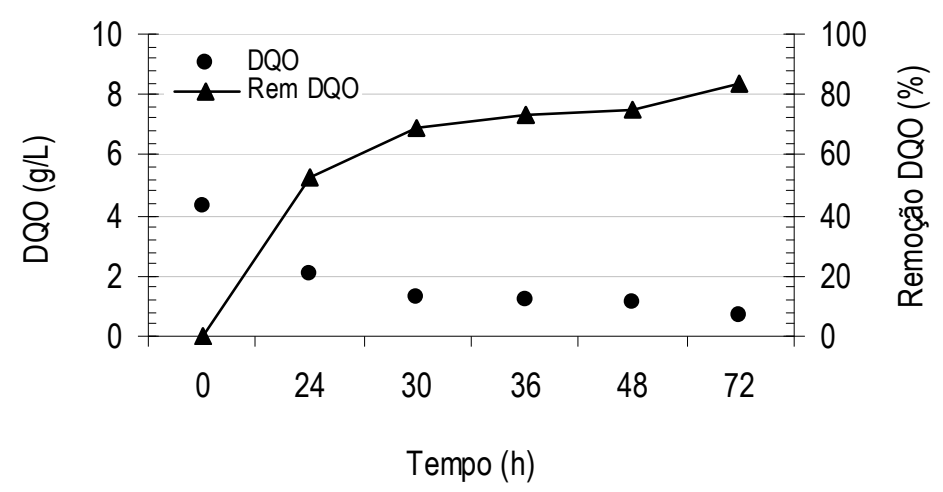

Figura 5.10 - Perfil temporal de remoção de DQO para avaliar tempo de ciclo da fase III. 
Após 30 horas, foi possível remover cerca de $70 \%$ da DQO inicial (Figura 5.10). Concomitantemente, foram realizados perfis de AVT e de AB (Figura 5.11). O $\mathrm{pH}$ ao longo do tempo foi de 8,12 $\pm 0,13$ e a relação entre AI/AP foi de 0,34 $\pm 0,02$.

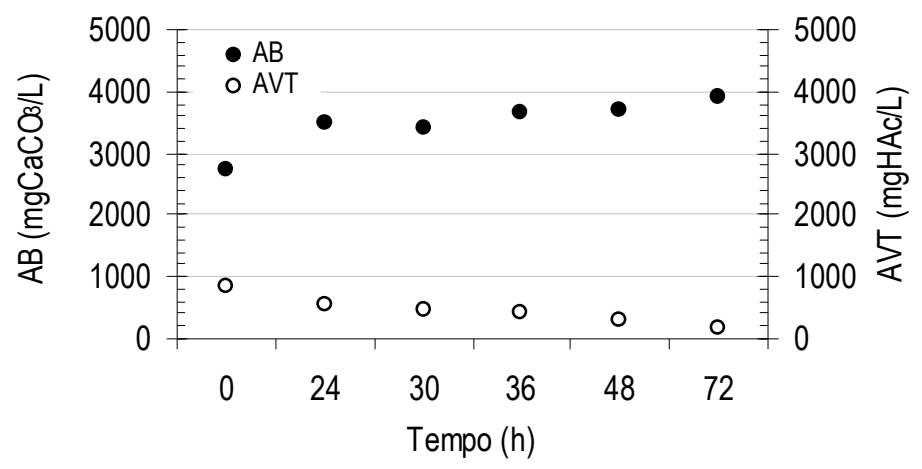

Figura 5.11 - Perfil temporal de AVT e de AB para avaliar tempo de ciclo da fase III.

De acordo com a Figura 5.11, observa-se que o perfil de degradação de ácidos voláteis totais ao longo da batelada foi lento. Houve aumento de pouco mais de 1150 $\mathrm{mg} / \mathrm{L}$ na alcalinidade a bicarbonato do efluente. $\mathrm{O}$ alto valor de $\mathrm{pH}(>8,0)$ foi devido à suplementação de bicarbonato afluente, da ordem de $0,8\left(\mathrm{HCO}_{3}{ }^{-} / \mathrm{DQO}\right)$.

Com base nos resultados desses perfis, adotou-se, para essa concentração de vinhaça, o tempo de ciclo de 1,5 dia (36 horas) por apresentar $73 \%$ de remoção de DQO, que se manteve constante entre 36 e 48 horas. Eficiência de remoção significativa (84\%) ocorreu apenas após 72 horas, quando houve queda de AVT para 180 mgHAc/L, equivalente a $21 \%$ da concentração inicial de ácidos. Assim, a carga orgânica aplicada nos ciclos seguintes foi de 3,3 gDQO/L.d com entrada de 5,0 gDQO/L e tempo de ciclo de 1,5 dia nessa fase experimental.

\section{Monitoramento da fase III - tempo de ciclo 1,5 d e 5,0 gDQO/L}

Nesta fase, o reator foi monitorado durante o período do $71^{\circ}$ até $94^{\circ}$ ciclo, com tempo de ciclo de 1,5 dia, totalizando 35 dias de operação. Os resultados médios dos parâmetros físico-químicos analisados estão na Tabela 5.5.

No início da fase, o reator apresentou $86 \%$ (no $71^{\circ}$ ciclo) de eficiência na remoção de DQO e no final $81 \%$ (93 ${ }^{\circ}$ ciclo $)$, que representou estabilidade dinâmica aparente. 
Tabela 5.5 - Parâmetros físico-químicos monitorados do afluente e efluente durante a fase III.

\begin{tabular}{lccc|ccc}
\hline \multicolumn{1}{c}{ Fase III - COV 3,3 gDQO/L.d - 5,0 gDQO/L } & \multicolumn{3}{c}{ Efluente } \\
\cline { 2 - 7 } \multicolumn{1}{c}{ Parâmetros } & Média \pm DP (nc)* & Mínimo & Máximo & Média \pm DP $(\mathrm{nc})$ & Mínimo & Máximo \\
\hline DQO (g/L) & $5,46 \pm 1,31(5)$ & 4,40 & 6,89 & $1,61 \pm 0,74(5)$ & 0,84 & 2,57 \\
$\mathrm{AB}(\mathrm{mg} \mathrm{CaCO} / \mathrm{L})$ & $2408 \pm 572,3(6)$ & 1390,4 & 2915,7 & $2737 \pm 733(6)$ & 1661,1 & 3616,2 \\
$\mathrm{AVT}(\mathrm{mgHAc} / \mathrm{L})$ & $708,4 \pm 181,2(6)$ & 485,6 & 962,4 & $640,3 \pm 267(6)$ & 299,1 & 984,4 \\
pH & $7,72 \pm 0,4(6)$ & 7,43 & 8,50 & $8,41 \pm 0,2(6)$ & 8,2 & 8,7 \\
$\mathrm{AI} / \mathrm{AP}$ & & & & $0,39 \pm 0,07$ & 0,33 & 0,50 \\
$\mathrm{ST}(\mathrm{mg} / \mathrm{L})$ & $6945 \pm 818(4)$ & 5800 & 7700 & $6000 \pm 1470(4)$ & 3800 & 6800 \\
$\mathrm{SV}(\mathrm{mg} / \mathrm{L})$ & $2402 \pm 358(4)$ & 1900 & 2708 & $1825 \pm 419(4)$ & 1400 & 2400 \\
\hline
\end{tabular}

* DP - desvio padrão; nc - números de ciclos analisados.

No ciclo $94^{\circ}$, foram realizados perfis temporais para obtenção de parâmetros cinéticos de decaimento de DQO e remoção de DQO (Figura 5.12), avaliação dos ácidos orgânicos (Figura 5.13) e de biogás (Figura 5.14) ao longo do ciclo.

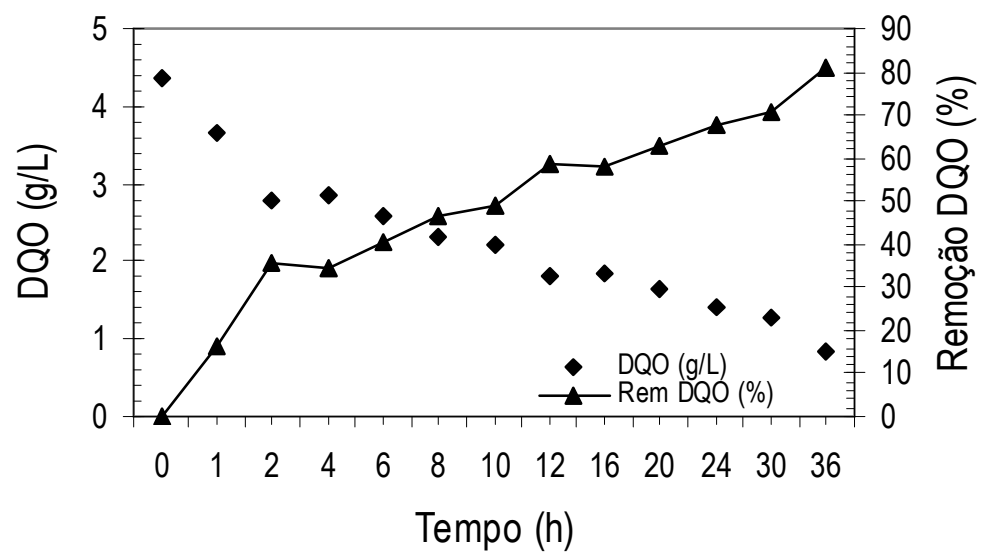

Figura 5.12 - Perfil de concentração de vinhaça em termos de DQO ao longo do $94^{\circ}$ ciclo da fase III.

Em 2 horas, houve $35 \%$ de remoção de DQO, mas o decaimento foi constante, atingindo mais que $80 \%$ ao final da batelada ( $36 \mathrm{~h}$ ), como mostra a Figura 5.12.

Quanto aos ácidos orgânicos, observou-se que o máximo valor foi atingido em 10 horas de ciclo, indicando, provavelmente, o fim da fase acidogênica (Figura 5.13).

O ácido propiônico se acumulou durante as 12 horas iniciais e foi totalmente consumido em 36 horas (restando somente 1,26 mg/L), assim como o ácido acético (residual de $18 \mathrm{mg} / \mathrm{L}$ ). Esse resultado é interessante, pois mostra que, em reatores operados em bateladas seqüenciais, pode ocorrer um desbalanceamento inicial entre a produção e o consumo de ácidos voláteis que pode levar ao acúmulo de propiônico. No 
entanto, se as concentrações de ácidos voláteis não atingiram níveis tóxicos para a biomassa metanogênica, esses ácidos são convertidos a metano até o final do ciclo.

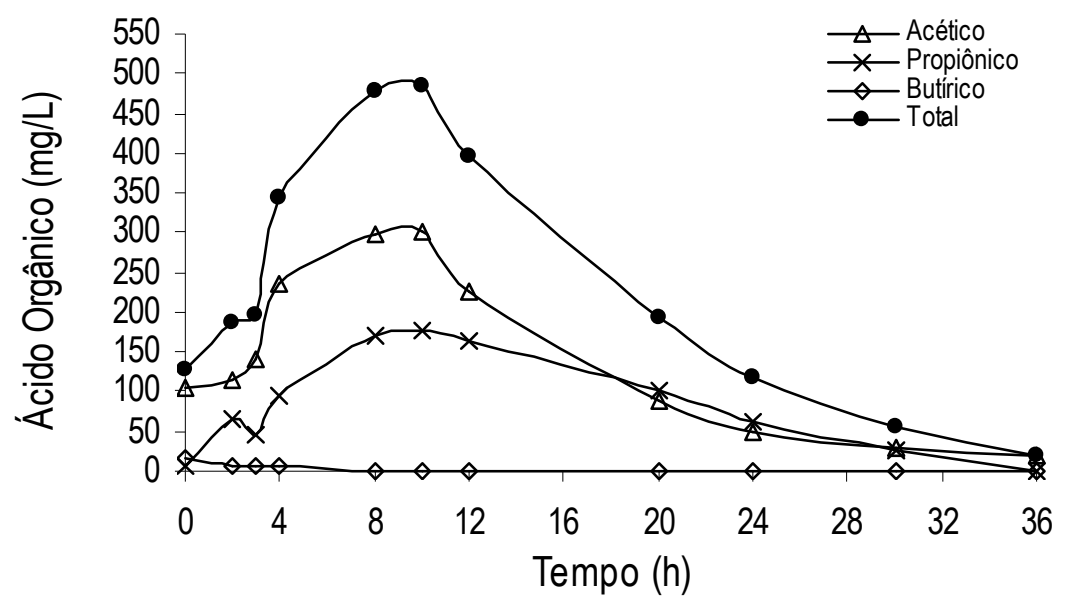

Figura 5.13 - Perfil de ácidos orgânicos ao longo do $94^{\circ}$ ciclo da fase III.

De 10 horas até 24 horas, foram quantificados cerca de 2,0 mg/L de fenol. Antes e depois deste período, foram detectados apenas traços desta substância em cromatografia gasosa. Possivelmente, a decomposição anaeróbia de algum tipo de substância complexa presente na vinhaça pode ter gerado esse composto que, depois de 24 horas, foi degradado por microrganismos. Fang \& Chang (1997), estudando a degradação de fenol em reator UASB, observaram que, nos grânulos anaeróbios, existiam quatro tipos de morfologias semelhantes a bactérias degradadoras de benzoato Syntrophus buswelli, arquéia acetotrófica como Methanosaeta e arquéias hidrogenotróficas como Methanospirillum hungatei e Methanobrevibacter. Os mesmos autores citam que a degradação de poluentes aromáticos, como o fenol, é potencializada em águas residuárias que também contêm altas concentrações de sulfato.

Quanto à produção de biogás, observa-se na Figura 5.14 que a produção máxima ocorreu na quarta hora da batelada tanto para os teores de metano como de gás carbônico. Com base nos perfis de metano apresentado, houve produção de 0,9 L de $\mathrm{CH}_{4}$ em 30 horas ou $0,7 \mathrm{~L}$ em um dia.

Ao longo de todo ciclo a porcentagem de metano aumentou de 46,5\% na primeira hora para 75,6 \% na trigésima hora do ciclo. Já o $\mathrm{CO}_{2}$ ficou entre 53,5 \% na $1^{\mathrm{a}}$ hora decaindo gradualmente até $24,4 \%$ na $30^{\text {a }}$ hora. 


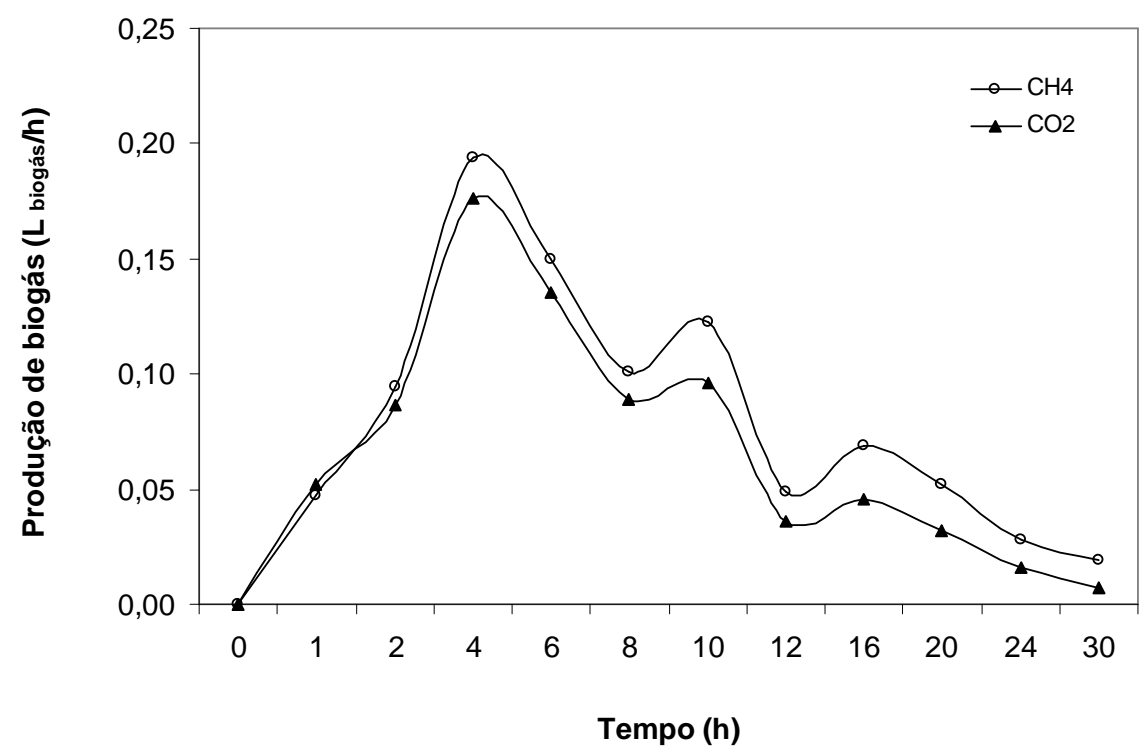

Figura 5.14 - Produção de $\mathrm{CH}_{4}$ e $\mathrm{CO}_{2}$ ao longo do $94^{\circ}$ ciclo da fase III.

\subsubsection{Operação do reator na fase IV com 10,0 gDQO/L e COV 3,3 gDQO/L.d}

\section{Ajuste do tempo de ciclo da fase IV pelo perfil temporal prévio}

A duração do ciclo em que foram realizados os perfis temporais foi 4 dias (96 horas). O perfil de decaimento de DQO e a eficiência de remoção estão mostrados na Figura 5.15.

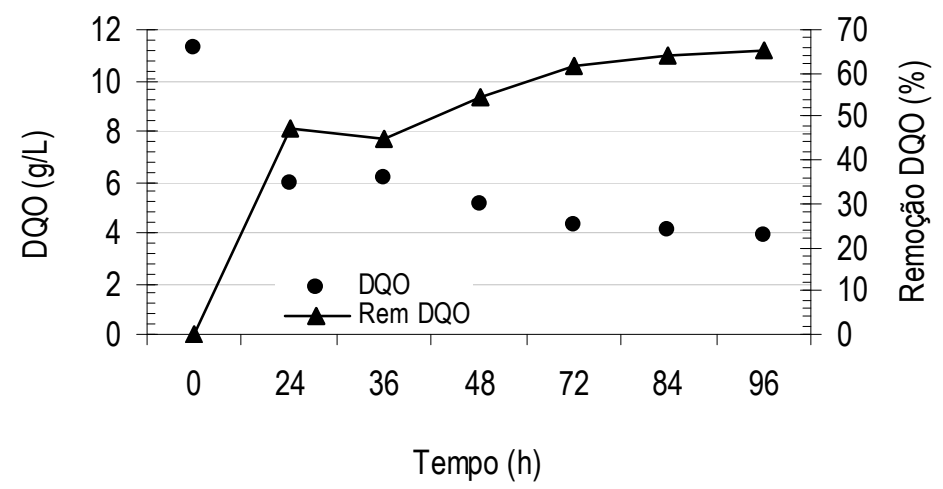

Figura 5.15 - Perfil temporal de remoção de DQO para avaliar tempo de ciclo da fase IV. 
Os perfis de AVT e de AB realizados estão apresentados na Figura 5.16. O pH ao longo do tempo foi de $8,27 \pm 0,26$ e a relação entre AI/AP foi de $0,48 \pm 0,06$, sendo que a relação de bicarbonato/DQO foi da ordem de 0,6 .

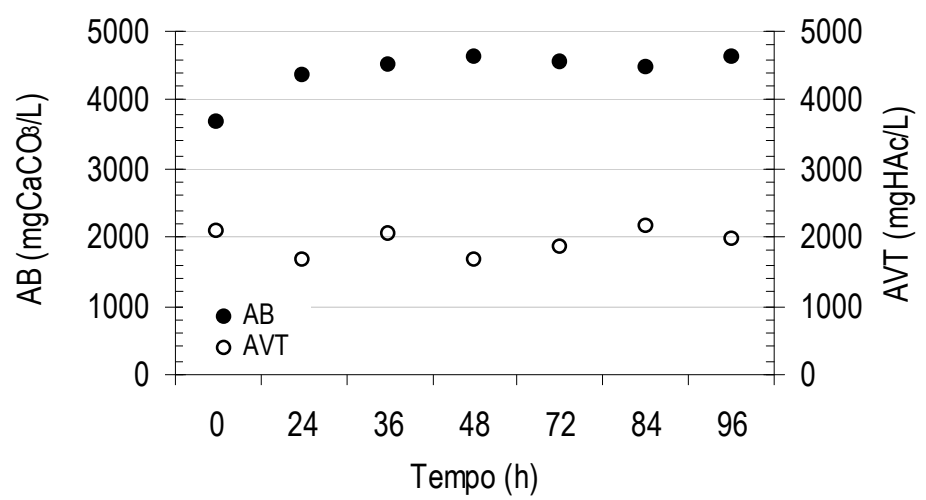

Figura 5.16 - Perfil temporal de AVT e de AB para avaliar tempo de ciclo da fase IV.

Após analisar os dados do perfil, foi adotado, para essa concentração de vinhaça, o tempo de ciclo de 3 dias (72 horas), por apresentar remoção constante de DQO, a partir deste ponto, de 60 - $65 \%$, e a carga orgânica volumétrica de 3,3 gDQO/L.d e relação de $\mathrm{HCO}_{3}{ }^{-} / \mathrm{DQO}$ de 0,6 .

Monitoramento da fase IV - tempo de ciclo 3,0 d e 10,0 gDQO/L

Nesta fase, o reator foi monitorado no período do $95^{\circ}$ ao $101^{\circ}$ ciclo, com tempo de ciclo de três dias, durante 13 dias de operação. Os resultados médios dos parâmetros físico-químicos monitorados estão na Tabela 5.6.

Tabela 5.6 - Parâmetros físico-químicos monitorados do afluente e efluente durante as fases IV.

\begin{tabular}{lccc|ccc}
\hline Fase IV - COV 3,3 gDQO/L.d - 10,0 gDQO/L & \multicolumn{3}{c}{ Efluente } \\
\cline { 2 - 7 } \multicolumn{1}{c}{ Parâmetros } & \multicolumn{3}{c}{ Afluente } & \multicolumn{3}{c}{} \\
\cline { 2 - 7 } & Média $\pm \mathrm{DP}(\mathrm{nc}) *$ & Mínimo & Máximo & Média $\pm \mathrm{DP}(\mathrm{nc})$ & Mínimo & Máximo \\
\hline $\mathrm{DQO}(\mathrm{g} / \mathrm{L})$ & $13,47 \pm 2,01(5)$ & 11,30 & 15,70 & $2,84 \pm 0,89(5)$ & 1,51 & 3,84 \\
$\mathrm{AB}(\mathrm{mg} \mathrm{CaCO} / \mathrm{L})$ & $3785 \pm 72(5)$ & 3689,1 & 3870,7 & $5818 \pm 204(5)$ & 5522,7 & 6030,3 \\
$\mathrm{AVT}(\mathrm{mgHAc} / \mathrm{L})$ & $1812 \pm 299,3(5)$ & 1567,06 & 2229,9 & $844,3 \pm 272(5)$ & 461 & 1227 \\
$\mathrm{pH}$ & $7,51 \pm 0,20(5)$ & 7,24 & 7,74 & $8,28 \pm 0,10$ & 8,14 & 8,42 \\
$\mathrm{AI} / \mathrm{AP}$ & & & & $0,36 \pm 0,05$ & 0,29 & 0,42 \\
$\mathrm{ST}(\mathrm{mg} / \mathrm{L})$ & $15950 \pm 1266(4)$ & 14700 & 17400 & $12675 \pm 3793(4)$ & 9500 & 18100 \\
$\mathrm{SV}(\mathrm{mg} / \mathrm{L})$ & $7175 \pm 818(4)$ & 6200 & 7900 & $4650 \pm 3848(4)$ & 1900 & 10300 \\
\hline
\end{tabular}

* DP - desvio padrão; nc - números de ciclos analisados. 
Observou-se aumento gradativo da eficiência ao longo dessa fase experimental, pois, no $98^{\circ}$ ciclo, a eficiência do reator era de $68 \%$ e, no $100^{\circ}$ ciclo, de $90 \%$. Então, no $101^{\circ}$ ciclo, foram realizados perfis temporais de DQO e remoção de DQO (Figura 5.17), produção e consumo de ácidos orgânicos (Figura 5.18) e de biogás (Figura 5.19) ao longo do ciclo.

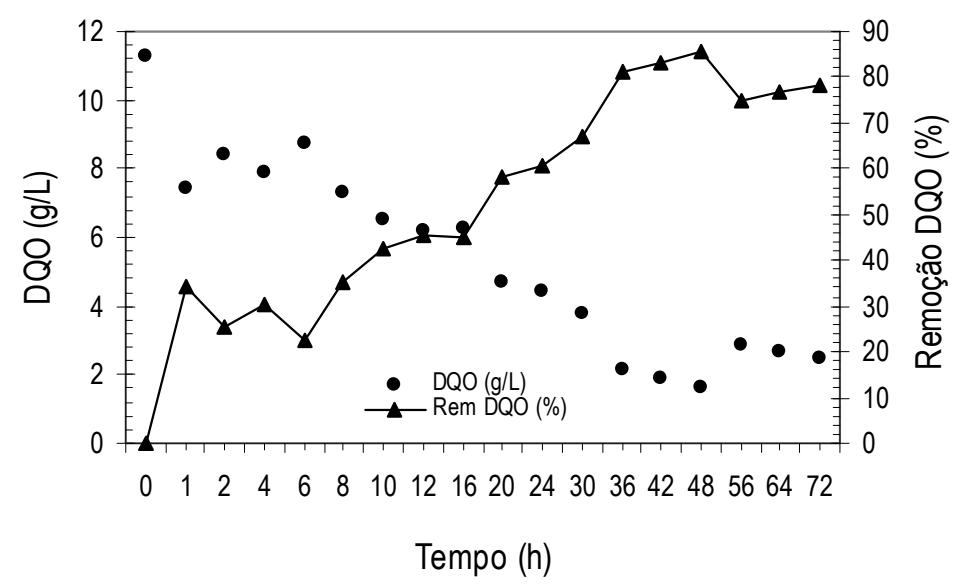

Figura 5.17 - Perfil de concentração de vinhaça em termos de DQO ao longo do $101^{\circ}$ ciclo da fase IV.

Em 16 horas, houve a maior remoção de DQO de aproximadamente $45 \%$ (Figura 5.17). Nesse mesmo período, foi observada maior produção de ácidos orgânicos (Figura 5.18). Mas, no final do ciclo, especificamente nas três últimas amostragens (56, 64 e 72 horas) observou-se aumento da DQO efluente. Este fato pode estar relacionado com a produção e/ou liberação de substâncias extracelulares que pode estar associada à falta de nutrientes no final do ciclo.

Aquino \& Stuckey (2005) caracterizaram por cromatografia os compostos dissolvidos como nos efluentes de reatores anaeróbios tratando água residuária sintética, pois o conhecimento atual sugere que a quantidade, origem e natureza dos polímeros solúveis extracelulares (do inglês, extracellular polymeric substances, EPS) dependem das características do afluente (tipo e concentração), condições ambientais (pH, deficiência nutricional, presença de compostos tóxicos), tipo de reator e parâmetros operacionais (TDH, cargas de choques).

Os autores anteriormente citados verificaram que a produção normalizada de EPS, isto é, a concentração de EPS dividida pela DQO afluente $\left(\mathrm{EPS} / \mathrm{S}_{0}\right)$ foi 2,1 \% para o reator de mistura completa e $25 \%$ para um reator anaeróbio de membrana, sendo que no reator de membrana a DQO efluente foi de $30 \mathrm{mg} / \mathrm{L}$, valor muito menor que a DQO 
no bulk líquido que foi de $142 \mathrm{mg} / \mathrm{L}$, sugerindo que houve um processo físico de filtração. Duas hipóteses justificariam a produção de substâncias solúveis, uma que pode ser atribuída aos reatores de alta taxa que têm o tempo de detenção celular muito maior que o TDH e outra, às condições de estresse como a necessidade nutricional, em que os microrganismos podem liberar fragmentos de células a partir da lise celular, estruturas internas de células, proteínas e ácidos nucléicos, que aumentam a DQO efluente.

O perfil temporal de ácidos orgânicos está apresentado na Figura 5.18.

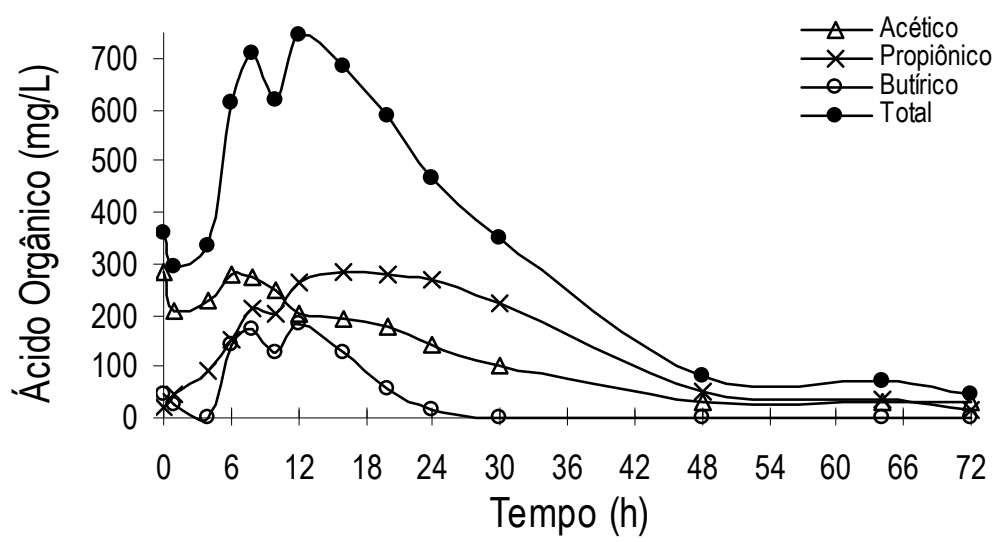

Figura 5.18 - Perfil de ácidos orgânicos ao longo do $102^{\circ}$ ciclo da fase IV.

O ácido propiônico atingiu valores maiores (265 - $283 \mathrm{mg} / \mathrm{L})$ que o ácido acético (193 - $205 \mathrm{mg} / \mathrm{L})$ a partir das 12 horas, sendo consumido até 13,74 mg/L em 72 horas.

O ácido butírico também se acumulou nas primeiras horas da batelada com pico de produção até 12 horas $(183,13 \mathrm{mg} / \mathrm{L})$, sendo totalmente consumido após 30 horas.

A partir das 16 horas, determinou-se $5,4 \mathrm{mg} / \mathrm{L}$ de fenol em média, e após 24 horas foi observado decaimento para valores menores que $<1,0 \mathrm{mg} / \mathrm{L}$.

A caracterização de DQO residual de sistemas biológicos tem mostrado que a maioria de compostos orgânicos no efluente não estava presente no afluente original, mas foram produzidos pelo sistema de tratamento (BARKER \& STUCKEY, 1999).

Nas primeiras 16 horas do ciclo houve maior produção de biogás (Figura 5.19) coincidindo com a fase de maior remoção de DQO e produção de ácidos orgânicos.

Com base no perfil, pode-se inferir que foi produzido aproximadamente $1,6 \mathrm{~L}$ de metano no ciclo todo que correspondeu à produção de $0,88 \mathrm{~g} \mathrm{CH}_{4}$ ou $0,54 \mathrm{~L} \mathrm{de} \mathrm{CH}_{4} / \mathrm{d}$. 
Ao final da batelada, a porcentagem de metano no biogás era de $70 \%$ em relação ao volume gasoso total do headspace.

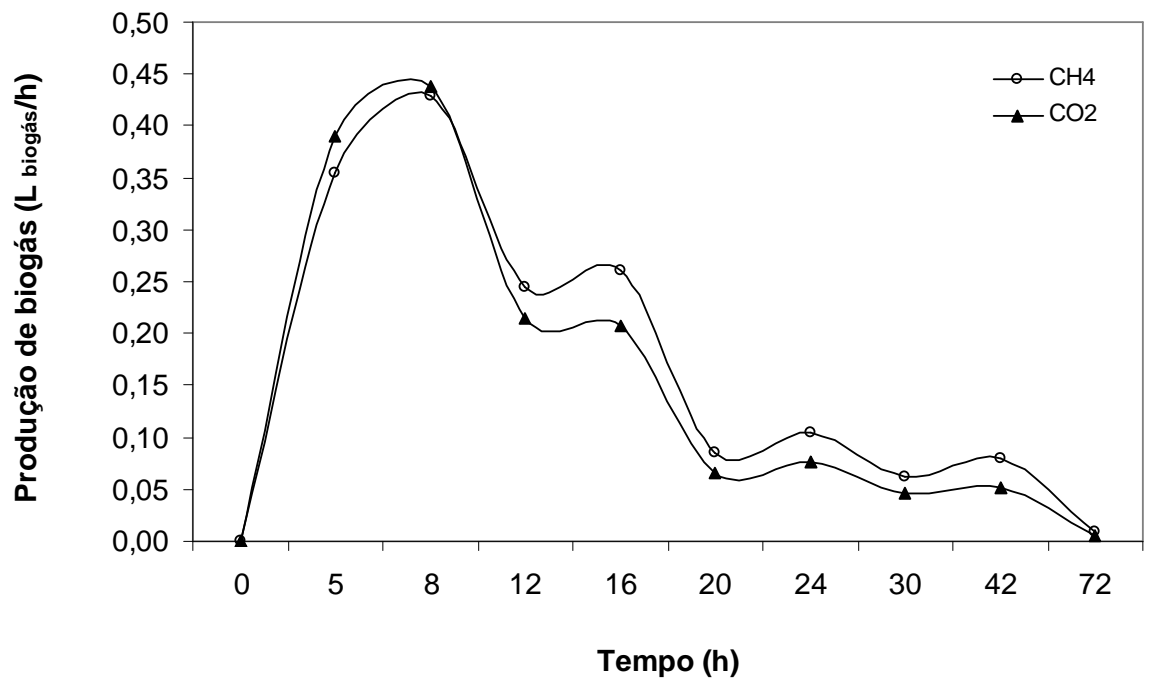

Figura 5.19 - Produção de $\mathrm{CH}_{4}$ e $\mathrm{CO}_{2}$ ao longo do $101^{\circ}$ ciclo da fase IV.

\subsubsection{Operação do reator na fase $\mathrm{V} \operatorname{com} 20,0 \mathrm{gDQO} / \mathrm{L}$ e COV 3,3 gDQO/L.d}

\section{Ajuste do tempo de ciclo da fase V pelo perfil temporal prévio}

A duração do ciclo em que foram realizados os perfis temporais de vários parâmetros para ajuste do tempo de ciclo foi 6 dias (144 horas), Figura 5.20.

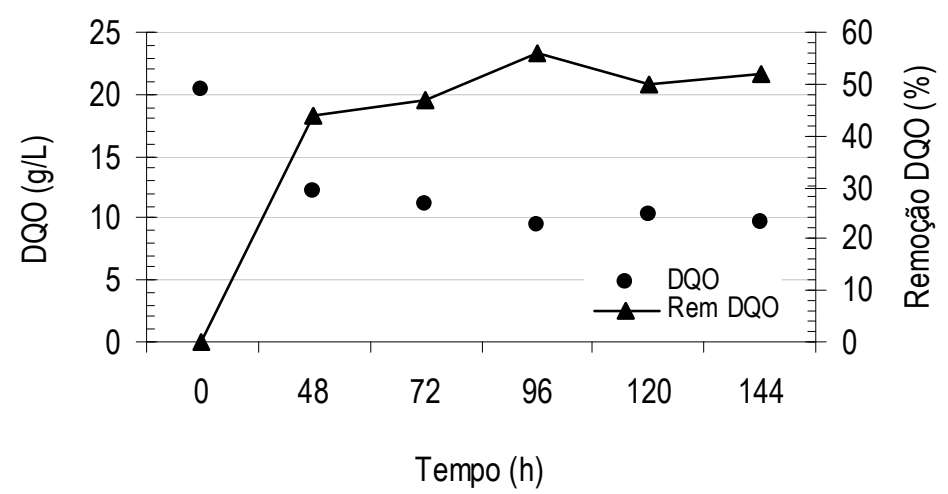

Figura 5.20 - Perfil temporal de remoção de DQO para avaliar tempo de ciclo da fase V. 
Os perfis de consumo de AVT e produção de AB estão apresentados na Figura 5.21. O pH ao longo do tempo foi de $8,13 \pm 0,32$ e a relação entre AI/AP foi de 0,55 \pm 0,12 e relação $\mathrm{HCO}_{3}{ }^{-} / \mathrm{DQO}$ de 0,6 .

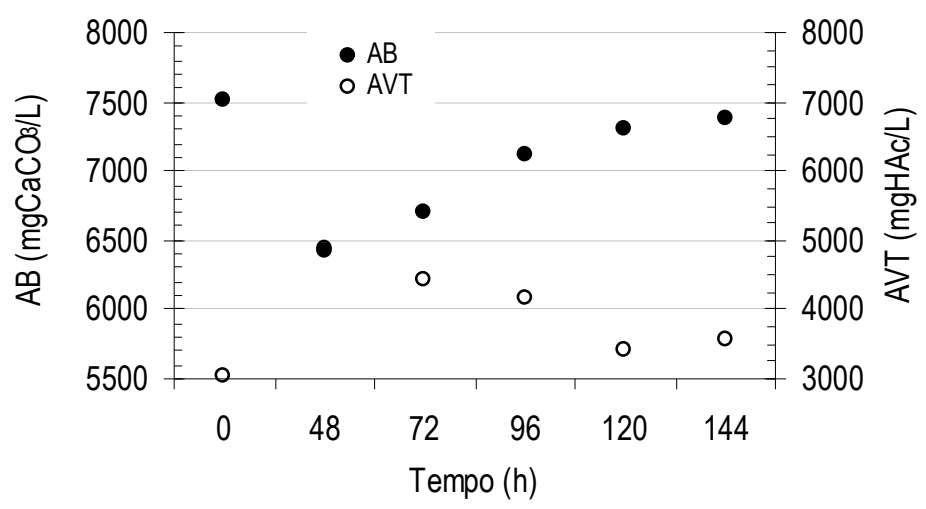

Figura 5.21 - Perfis temporais de AVT e de AB para avaliar tempo de ciclo da fase V.

Diferentemente dos perfis anteriores, observa-se, na Figura 5.21, que grande parte da $\mathrm{AB}$ afluente foi consumida nas primeiras 48 horas, indicando que os processos anaeróbios produtores de íons bicarbonatos como redução desassimilatória de sulfato e metanogênese acetotrófica, poderiam não estar ocorrendo bem até este período.

O consumo de AVT teve início após 96 horas e a eficiência de remoção de DQO se estabilizou em torno de $50-55 \%$. Nesse momento da batelada, os valores de AVT ainda estavam muitos altos, em cerca de $4200 \mathrm{mg} / \mathrm{L}$, e deveriam ser consumidos para evitar o colapso do reator.

Também foi observada tendência de aumento da $\mathrm{AB}$ de $7112 \mathrm{mgCaCO}_{3} / \mathrm{L} \mathrm{em} 96$ horas.

Portanto, para essa concentração de vinhaça, foi adotado um tempo de ciclo maior, de 6 dias (144 horas), por apresentar constância na remoção de DQO (de aproximadamente $50 \%$ ) deste ponto em diante e maior consumo de ácidos (3000 3500 mg/L), mantendo-se a carga orgânica volumétrica de 3,3 gDQO/L.d. Apesar de ser um tempo de ciclo longo, o ensaio foi necessário para se verificar a possibilidade de restabelecimento da eficiência do reator. 


\section{Monitoramento da fase $V$ - tempo de ciclo 6,0 d e 20,0 gDQO/L}

Nesta fase, o reator foi monitorado durante o período do $102^{\circ}$ ao $123^{\circ}$ ciclo, com tempo de ciclo de seis dias, totalizando 111 dias de operação. Os resultados médios dos parâmetros físico-químicos analisados estão na Tabela 5.7.

Tabela 5.7 - Parâmetros físico-químicos monitorados do afluente e efluente durante as fases $\mathrm{V}$.

\begin{tabular}{lccc|ccc}
\hline Fase V - COV 3,3 gDQO/L.d - 20,0 gDQO/L & \multicolumn{4}{c}{ Efluente } \\
\cline { 2 - 7 } \multicolumn{1}{c}{ Parâmetros } & \multicolumn{3}{c|}{ Afluente } & \multicolumn{3}{c}{} \\
\cline { 2 - 7 } & Média $\pm \mathrm{DP}(\mathrm{nc}) *$ & Mínimo & Máximo & Média $\pm \mathrm{DP}(\mathrm{nc})$ & Mínimo & Máximo \\
\hline $\mathrm{DQO}(\mathrm{g} / \mathrm{L})$ & $23,98 \pm 3,29(10)$ & 18,17 & 27,70 & $10,7 \pm 2,12(10)$ & 7,70 & 13,62 \\
$\mathrm{AB}(\mathrm{mg} \mathrm{CaCO} / \mathrm{L})$ & $5657 \pm 1085(10)$ & 4244,6 & 7506,5 & $5847 \pm 1303(10)$ & 3685,3 & 7472,6 \\
$\mathrm{AVT}(\mathrm{mgHAc} / \mathrm{L})$ & $3554 \pm 790(10)$ & 2583,7 & 4745,4 & $3435,1 \pm 939(10)$ & 1774 & 4795 \\
$\mathrm{pH}$ & $7,4 \pm 0,5(10)$ & 6,4 & 8,3 & $8,27 \pm 0,4$ & 7,4 & 8,7 \\
$\mathrm{AI} / \mathrm{AP}$ & & & & $0,58 \pm 0,2$ & 0,25 & 0,85 \\
\hline
\end{tabular}

* DP - desvio padrão; nc - números de ciclos analisados.

A eficiência na remoção de DQO média foi de $55 \%$, com tendência à queda de eficiência, variando de $68 \%$ (ciclo 104) a $43 \%$ (ciclo 117). Devido à baixa eficiência, não foram realizados perfis temporais para obtenção dos parâmetros cinéticos nessa fase.

\subsubsection{Operação do reator na fase VI}

A fase VI foi realizada com intenção de recuperar o reator após a concentração aplicada na fase V de 20g/L, expressa em DQO, o que provocou, provavelmente, um choque aos microrganismos, pela alta concentração de ácidos voláteis totais ao longo de todo o ciclo avaliado, de $3906 \pm 696 \mathrm{mgHAc/L}$, que não foram consumidos. Nesta fase, também não foram realizados perfis temporais. Portanto, inicialmente retrocedeu-se às condições da fase III, que apresentou bons resultados de remoção de DQO maiores que $70 \%$ e consumo de ácidos voláteis.

Após 110 dias, foram observadas maiores eficiências de remoção de DQO, da ordem de $60 \%$, propiciando assim, o possível aumento da concentração de vinhaça, ou seja, a mudança de fase. 
Nesta fase, o reator foi monitorado durante o período do $124^{\circ}$ ao $170^{\circ}$ ciclo, totalizando 109 dias. Inicialmente, o reator foi alimentado com vinhaça na concentração teórica de 5,0 gDQO/L e tempo de ciclo de 1,5 dia (COV 3,3 gDQO/L.d) do $124^{\circ}$ ao $129^{\circ}$ ciclo, depois $10 \mathrm{gDQO} / \mathrm{L}$ e tempo de ciclo de três dias (COV 3,3 gDQO/L.d) do $130^{\circ}$ ao $140^{\circ}$ ciclo. Em seguida, o tempo de ciclo foi diminuído para 1,5 dia do 141 ao $144^{\circ}$ ciclo (COV 6,6 gDQO/L.d). Imediatamente, foi observada queda de eficiência, então o tempo foi aumentado para 2,5 dias, do $145^{\circ}$ ao $170^{\circ}$ ciclo (COV 4,0 gDQO/L.d).

Os resultados médios dos parâmetros físico-químicos analisados nesta fase estão na Tabela 5.8.

Tabela 5.8 - Parâmetros físico-químicos monitorados do afluente e efluente da fase VI.

\begin{tabular}{|c|c|c|c|c|c|c|}
\hline \multicolumn{7}{|c|}{ Fase VI - COV 3,3 - 6,6 gDQO/L.d } \\
\hline \multirow{2}{*}{ Parâmetros } & \multicolumn{3}{|c|}{ Afluente } & \multicolumn{3}{|c|}{ Efluente } \\
\hline & Média $\pm \mathrm{DP}(\mathrm{nc})^{*}$ & Mínimo & Máximo & Média \pm DP $(n c)$ & Mínimo & Máximo \\
\hline DQO (g/L) & $12,04 \pm 3,89(15)$ & 6,21 & 20,75 & $5,94 \pm 1,27(15)$ & 4,12 & 8,31 \\
\hline $\mathrm{AB}(\mathrm{mg} \mathrm{CaCO} / \mathrm{L})$ & $2170 \pm 686(17)$ & 1148,4 & 3069,5 & $2066 \pm 661(17)$ & 1064,4 & 3282,4 \\
\hline $\operatorname{AVT}(\mathrm{mgHAc} / \mathrm{L})$ & $1567 \pm 245(17)$ & 1072,8 & 1987 & $2401 \pm 468(17)$ & 1560,9 & 3062 \\
\hline $\mathrm{pH}$ & $7,15 \pm 0,22(17)$ & 6,83 & 7,5 & $7,61 \pm 0,24(17)$ & 7,2 & 7,9 \\
\hline $\mathrm{AI} / \mathrm{AP}$ & & & & $1,0 \pm 0,25$ & 0,67 & 1,7 \\
\hline $\mathrm{ST}(\mathrm{mg} / \mathrm{L})$ & $16003 \pm 8882(9)$ & 6300 & 27400 & $11542 \pm 5290(9)$ & 6300 & 20800 \\
\hline $\mathrm{SV}(\mathrm{mg} / \mathrm{L})$ & $6404 \pm 4444(9)$ & 700 & 11700 & $3510 \pm 2300(9)$ & 800 & 6300 \\
\hline
\end{tabular}

* DP - desvio padrão; nc - números de ciclos analisados.

Do ciclo 124 ao 138, em que a concentração de vinhaça manteve-se na faixa de 5 a $15 \mathrm{~g} / \mathrm{L}$, em DQO, foram obtidas eficiências de $15 \%$ (124 ciclo) a $69 \%$ (ciclo 141). A partir do ciclo 144, foi observada a instabilidade do sistema, demonstrada pela variação da eficiência que caiu para $40 \%$ no ciclo 155 , aumentando para $66 \%$ no ciclo 161 e voltando a diminuir para $42 \%$ no ciclo 164 . Esta variação pode ser detalhadamente observada na Figura 5.30, em que está apresentada uma comparação de todas as fases ao longo de todo período experimental em condições termofílicas.

As instabilidades das condições operacionais na fase VI foram ocasionadas pelas estratégias adotadas para o aumento da COV e recuperação do sistema. 


\subsubsection{Operação do reator na fase VII com 10,0 gDQO/L e COV 5,0 gDQO/L.d}

\section{Ajuste do tempo de ciclo da fase VII pelo perfil temporal prévio}

Nesta fase, a concentração afluente foi aumentada para 10,0 gDQO/L e tempo de ciclo de 2 dias (48 horas) (Figura 5.22).

Observa-se que, nas primeiras 16 horas, a DQO afluente (16,3 gDQO/L) já havia sido degradada para 7,15 gDQO/L (remoção de $56 \%$ ), embora este ainda seja considerado um valor inadequado para disposição do efluente.

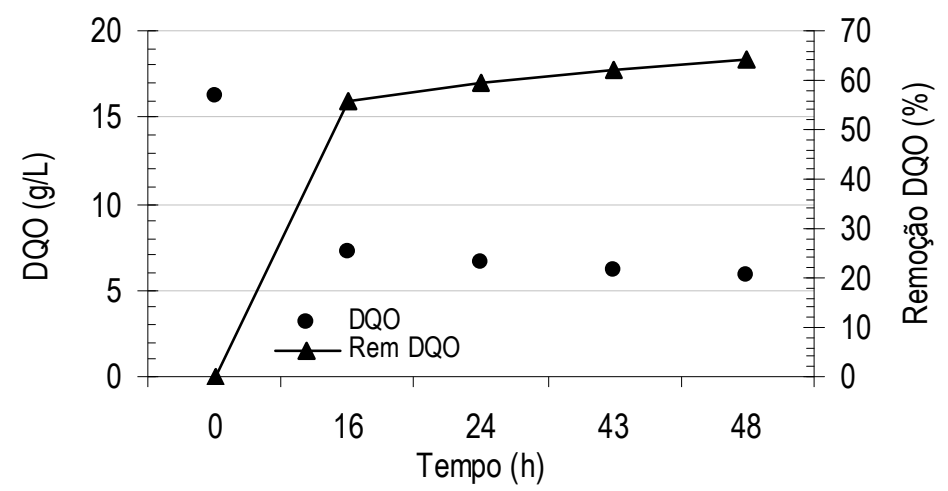

Figura 5.22 - Perfil temporal de remoção de DQO para avaliar tempo de ciclo da fase VII.

No final do ciclo avaliado (48 horas), o efluente ainda apresentava alto valor de DQO (5,85 g/L) e de AVT (1952 mg/L) (Figura 5.23). Manteve-se, no entanto, o tempo de ciclo de 48 horas para verificar se ocorreria a adaptação da biomassa a esta carga orgânica (5,0 gDQO/L.d) e possível redução de valores dos parâmetros de DQO e ácidos voláteis efluente, posteriormente.

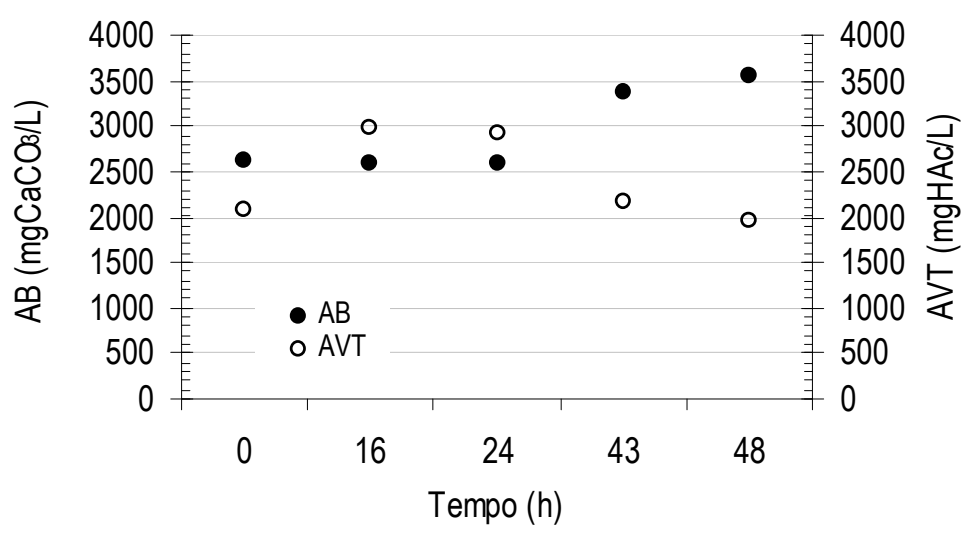

Figura 5.23 - Perfil temporal de AVT e de AB para avaliar tempo de ciclo da fase VII. 
O aumento da carga orgânica aplicada nas fases consecutivas foi acompanhado de aumento da relação de AI/AP, sendo observado, nessa fase, uma relação de 0,65 \pm 0,16 e $\mathrm{pH}$ de $8,00 \pm 0,21$.

\section{Monitoramento da fase VII - tempo de ciclo 2,0 de 10,0 gDQO/L}

Nesta fase, o reator foi monitorado durante o período do $171^{\circ}$ ao $194^{\circ}$ ciclo, com tempo de ciclo de dois dias, totalizando 43 dias de operação. Os resultados médios dos parâmetros físico-químicos analisados estão na Tabela 5.9.

Tabela 5.9 - Parâmetros físico-químicos monitorados no afluente e efluente da fase VII.

\begin{tabular}{|c|c|c|c|c|c|c|}
\hline \multicolumn{7}{|c|}{ Fase VII - COV 5,0 gDQO/L.d- 10,0 gDQO/L } \\
\hline \multirow{2}{*}{ Parâmetros } & \multicolumn{3}{|c|}{ Afluente } & \multicolumn{3}{|c|}{ Efluente } \\
\hline & Média \pm DP $(n c)^{*}$ & Mínimo & Máximo & Média \pm DP $(n c)$ & Mínimo & Máximo \\
\hline DQO (g/L) & $10,74 \pm 3,07(7)$ & 7,24 & 15,30 & $2,59 \pm 0,60(7)$ & 1,82 & 3,53 \\
\hline $\mathrm{AB}\left(\mathrm{mg} \mathrm{CaCO} \mathrm{Ca}_{3} / \mathrm{L}\right)$ & $2876,7 \pm 151(3)$ & 2770,1 & 2983,3 & $4573 \pm 809(3)$ & 4001,1 & 5144,6 \\
\hline AVT (mgHAc/L) & $1719,8 \pm 40,2(3)$ & 1691,4 & 1748,2 & $881,2 \pm 604(3)$ & 454,1 & 1308,3 \\
\hline $\mathrm{pH}$ & $7,7 \pm 0,5(3)$ & 7,4 & 8,2 & $8,13 \pm 0,2$ & 8,0 & 8,3 \\
\hline $\mathrm{AI} / \mathrm{AP}$ & & & & $0,33 \pm 0,16$ & 0,17 & 0,5 \\
\hline
\end{tabular}

* DP - desvio padrão; nc - números de ciclos analisados.

Nesta fase, a eficiência de remoção de DQO média foi de $75 \%$, com aumento progressivo de $68 \%$ no ciclo 179 a $85 \%$ no ciclo 194 , demonstrando recuperação do sistema.

Então, perfis em triplicata foram realizados nos ciclos 185, 190 e 193 com relação aos parâmetros DQO e remoção, produção e consumo de ácidos orgânicos, fenol, biogás, pH, sulfato e sulfeto, que estão apresentados nas Figuras 5.24, 5.25, 5.26, $5.27,5.28$ e 5.29 . 


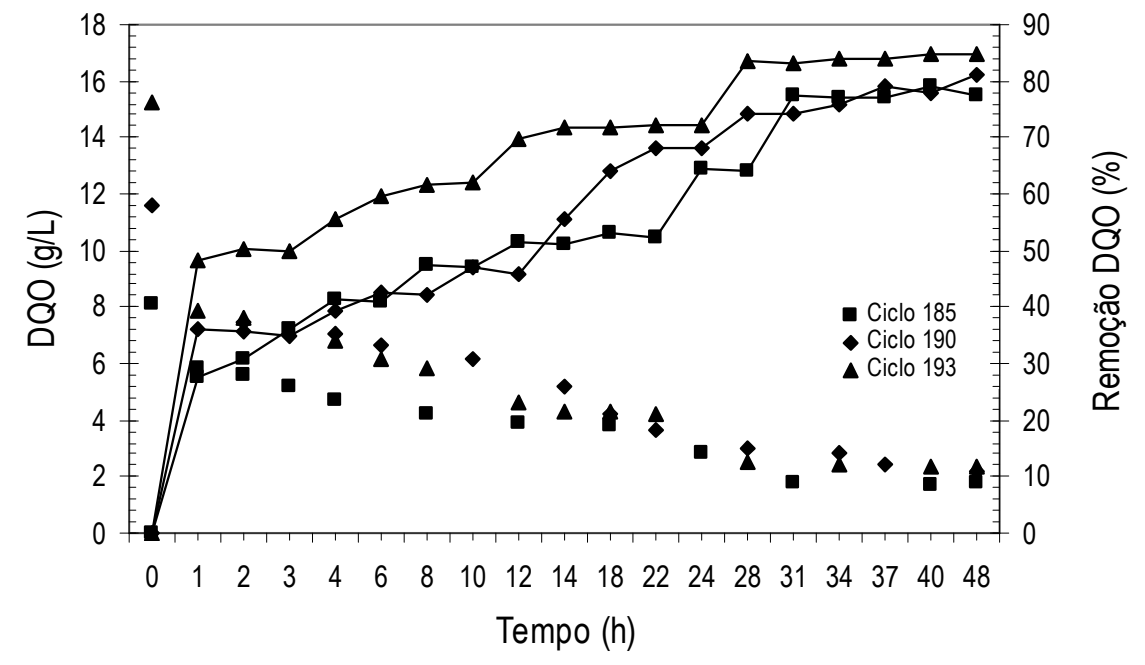

Figura 5.24 - Perfis de concentração de vinhaça em termos de DQO ao longo dos ciclos 185,190 e 193 da fase VII.

Apesar de os perfis não apresentarem curvas coincidentes, tanto de DQO como de ácidos orgânicos, ao final da batelada nos três ciclos foram atingidos valores próximos: para DQO de 1,8, 2,2 e 2,3 g/L nos ciclos 185, 190 e 150 e para ácidos orgânicos de 137, 147 e 84 mg/L nos respectivos ciclos.

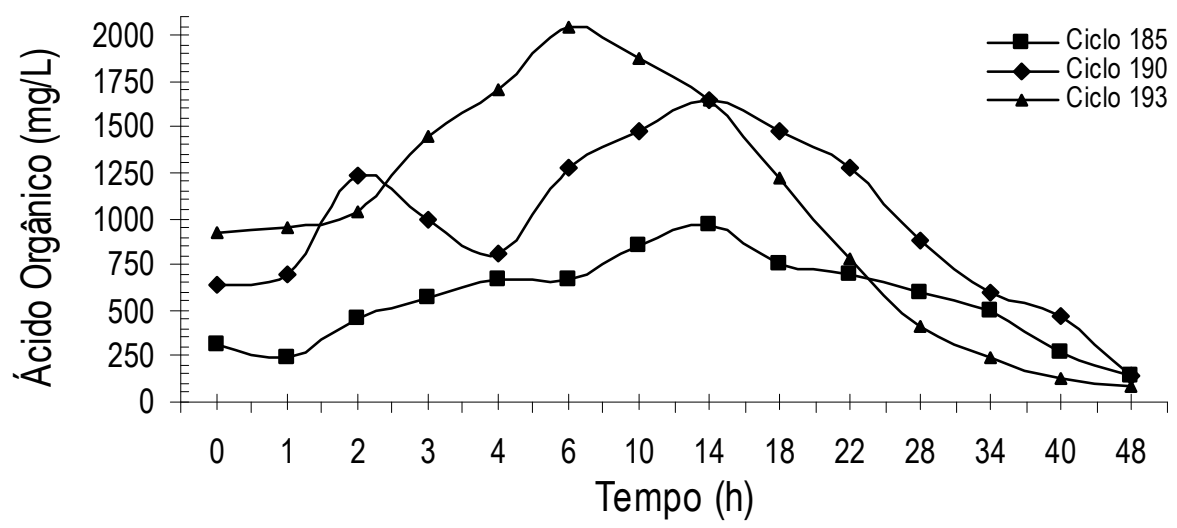

Figura 5.25 - Perfil de ácidos orgânicos totais ao longo dos ciclos 185, 190 e 193 da fase VII.

Na Figura 5.26, estão apresentados os perfis de fenol detectado nos ciclos analisados. 


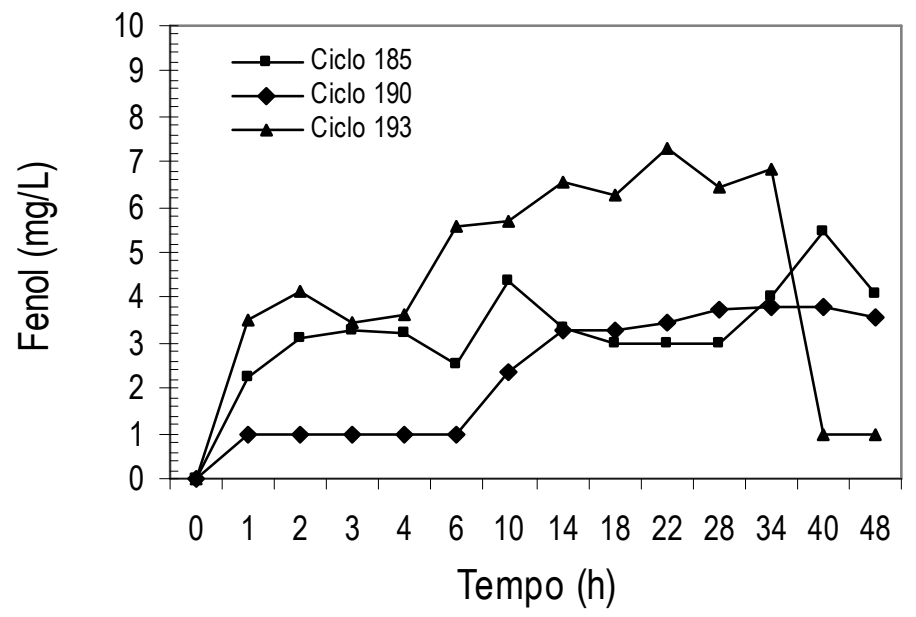

Figura 5.26 - Perfis de fenol ao longo dos ciclos 185, 190 e 193 da fase VII.

Observa-se, na Figura 5.26, que, diferentemente dos perfis das cargas anteriores, houve acúmulo de fenol ao longo da batelada de cada ciclo analisado. Nos ciclos 185 e 190 esse acúmulo foi, em média, de 3,81 mg/L (48 horas), mas o mesmo comportamento não foi observado no ciclo 193, em que ocorreram os maiores valores de fenol (7,31 mg/L em 22 horas) e consumo a partir de 40 horas de ciclo, atingindo valores menores $1,0 \mathrm{mg} / \mathrm{L}$.

Como anteriormente citado, o fenol pode ter sido originado durante a degradação de algum composto complexo da vinhaça como polifenóis que dão coloração esverdeada e compõe o aroma do caldo de cana-de-açúcar.

De modo geral, a produção de biogás nos três perfis apresentou o mesmo comportamento do perfil observado no ciclo 185 (Figura 5.27). Foram produzidos, em média, $0,78 \mathrm{~L}_{\text {de }} \mathrm{CH}_{4} / \mathrm{d}$ ou 1,5 L em 48 horas, que correspondeu em média a $0,8 \mathrm{gCH}_{4}$ em todo ciclo.

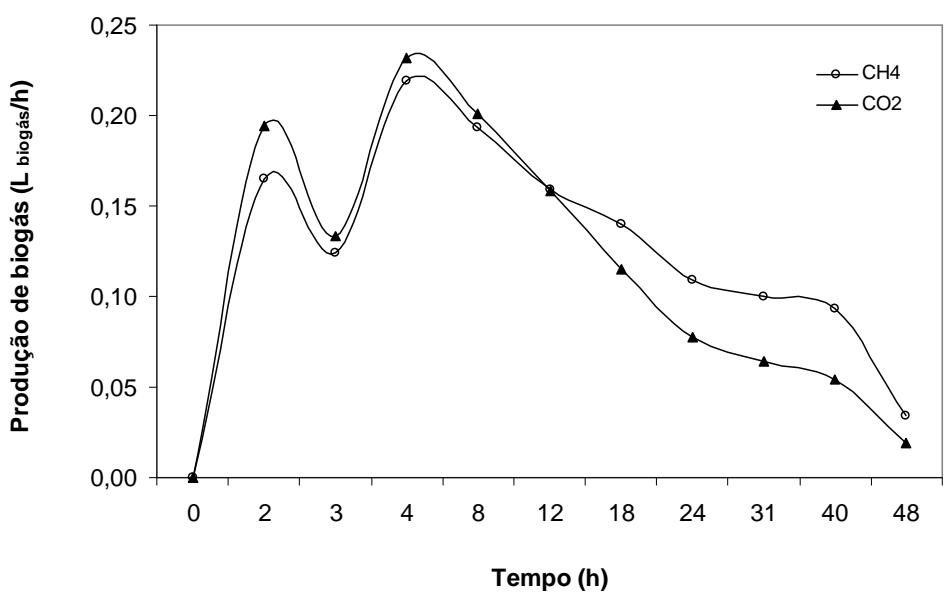

Figura 5.27 - Produção de $\mathrm{CH}_{4}$ e $\mathrm{CO}_{2}$ do ciclo 185 da fase VII. 
Observou-se que os valores de $\mathrm{pH}$ flutuaram em todos os perfis entre 7,2 e 8,5 conforme pode ser visto na Figura 5.28.

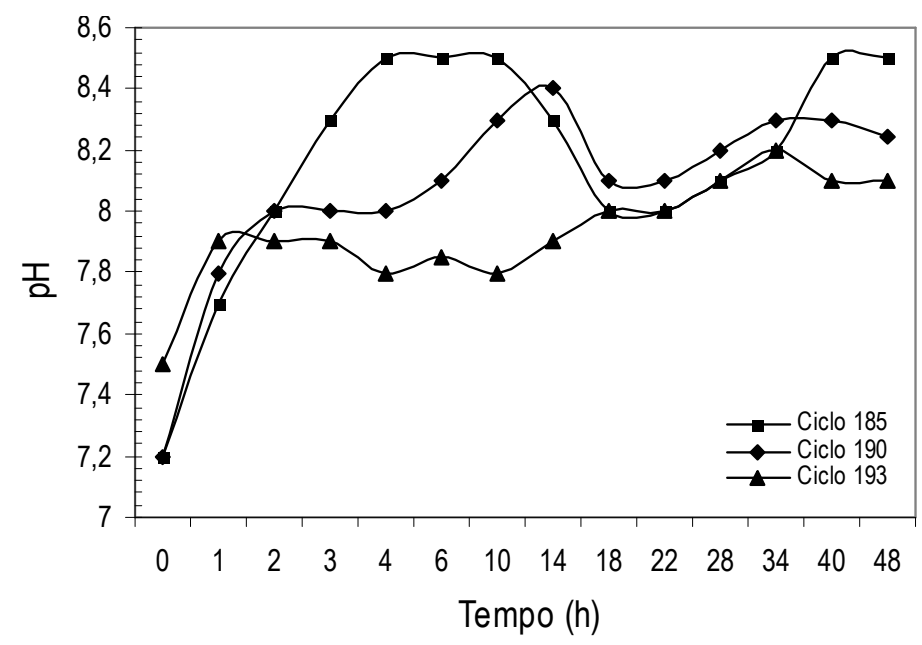

Figura 5.28 - Perfil de pH ao longo dos ciclos 185, 190 e 193 da fase VII.

Com relação à remoção de sulfato, observa-se, na Figura 5.29, que há total eliminação do íon sulfato em 4 horas da batelada.

As bactérias redutoras de sulfato (BRS), ao realizarem a redução desassimilativa do íon sulfato, na qual este íon atua como agente oxidante para a metabolização da matéria orgânica, o sulfato é utilizado como aceptor final de elétrons na cadeia de transporte de elétrons, gerando íons sulfeto. Apenas uma pequena parcela do enxofre reduzido é assimilada pelos microrganismos, sendo a maior parte excretada na forma de íon sulfeto normalmente hidrolisado a $\mathrm{H}_{2} \mathrm{~S}$ livre (POSTGATE, 1984).

O crescimento das BRS mesofílicas, a $30^{\circ} \mathrm{C}$, é normalmente lento podendo levar semanas de acordo com a espécie. Por outro lado, as BRS termofílicas crescem rapidamente em torno de 12 a $18 \mathrm{~h}$, a $55^{\circ} \mathrm{C}$. A faixa de $\mathrm{pH}$ ótima para desenvolvimento desses microrganismos é de 7,2 a 7,6 (SÉRVULO, 1991), que foi observada no intervalo de intervalo de 4 horas iniciais especialmente nos ciclos 190 e 193.

Segundo Sipma et al. (2000), acetato ou $\mathrm{H}_{2}$ desempenham importante papel como doadores de elétron na redução de sulfato hidrogenotrófica $\left(4 \mathrm{H}_{2}+\mathrm{SO}_{4}{ }^{2-}+\mathrm{H}^{+} \rightarrow\right.$ $\mathrm{HS}^{-}+4 \mathrm{H}_{2} \mathrm{O}$ ), sendo importante considerar a melhor relação entre $\mathrm{DQO} / \mathrm{SO}_{4}{ }^{2-}$. 


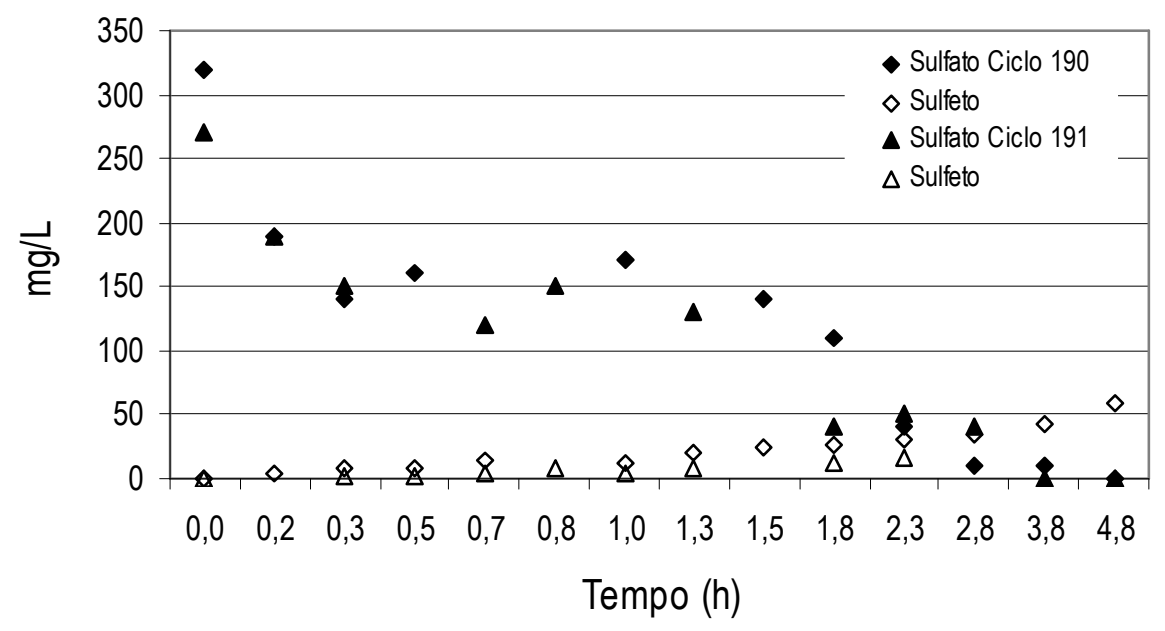

Figura 5.29 - Perfil de sulfato e sulfeto ao longo dos ciclos 190 e 191 da fase VII.

A redução de sulfato termofílica foi avaliada em $\mathrm{pH} 6,5$ e 4 e relações $\mathrm{DQO} / \mathrm{SO}_{4}{ }^{2-}$ de 10 e 4 durante a acidificação da sacarose em reator UASB com 5,0 gDQO/L.d por Castro Lopes et al. (2005). Em pH 6,0 e DQO/ $\mathrm{SO}_{4}{ }^{2-}$ de 10 a redução de sulfato foi completa. Em pH 5,0 a redução de sulfato variou em 80-95 \% para ambas relações $\mathrm{DQO} / \mathrm{SO}_{4}{ }^{2-}$, entretanto, em $\mathrm{pH} 4,0$ a eficiência de remoção foi de 55-65\% numa relação $\mathrm{DQO} / \mathrm{SO}_{4}{ }^{2-}$ de 10 e de 30-40\% na relação $\mathrm{DQO} / \mathrm{SO}_{4}{ }^{2-}$ de 4 . Os reatores mostraram completa acidificação de sacarose em todos os valores de $\mathrm{pH}$ e relações de $\mathrm{DQO} / \mathrm{SO}_{4}{ }^{2-}$. O pH diminuiu de 6,0 para 5,0 ou 4,0 causou uma mudança nos produtos da acidificação do acetato para butirato, maior produção de propionato $(\mathrm{pH} 5,0)$ e maior produção de etanol ( $\mathrm{pH} 4,0)$. Em $\mathrm{pH}$ 4,0 foi observada maior concentração de

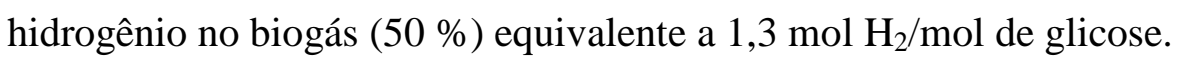

Damianovic et al. (2005) avaliaram a adaptação de biofilme para redução de sulfato em quatro reatores horizontais anaeróbios com biomassa imobilizada com diferentes relações $\mathrm{DQO} / \mathrm{SO}_{4}{ }^{2-}$ com tempo de detenção hidráulica de 12 horas e testaram o carvão vegetal (nos reatores R1 e R2) e espuma de poliuretano (nos reatores R3 e R4) como materiais suporte. Os reatores foram submetidos a concentrações de sulfato de 500 a $3000 \mathrm{mg} / \mathrm{L}$ e relações $\mathrm{DQO} / \mathrm{SO}_{4}{ }^{2-}$ de 5,0 to 1,7 . Os reatores com o mesmo suporte (R1 e R2) apresentaram eficiência na remoção de sulfato superior a $90 \%$, com predominância de redução na primeira seção do reator R4 que tinha comprimento total de $1,0 \mathrm{~m}$ e diâmetro de $5,0 \mathrm{~cm}$.

Esses resultados estão em acordo com dados de outros autores citados pela autora, como Sipma et al. (1999) que observou redução de sulfato sob condições 
acidificantes em pH 6,0 em reator UASB e relações DQO/SO ${ }_{4}^{2-}$ de 1,33 e 6,67, que é considerada uma das fases iniciais do processo de degradação anaeróbia e, de Vassoughi et al. (2003) que obteve remoção na primeira câmara de um reator anaeróbio tipo compartimentado. Este comportamento pode ser explicado pela alta afinidade das BRS ao substrato quando sulfato está presente no meio.

Pender et al. (2004) avaliaram a diversidade e a dinâmica populacional de metanogênicas em lodo granular de reatores híbridos tratando vinhaça de melaço mesofilicamente $\left(37^{\circ} \mathrm{C}\right)$ e termofilicamente $\left(55^{\circ} \mathrm{C}\right)$ durante 1081 dias. No reator mesofílico foi observado a predominância de Methanosaeta tanto na presença como na ausência de sulfato. No termofílico, foi observado Methanocorpusculum parvum sem sulfato e Methanobacterium thermoautotrophicum na presença de sulfato $(3,0 \mathrm{~g} / \mathrm{L})$. Observaram ainda que a conversão metanogênica de acetato (atividade acetoclástica) em $55{ }^{\circ} \mathrm{C}$ foi extremamente sensível pela inibição de sulfeto $(50 \%$ inibição com 8 a $17 \mathrm{mg} / \mathrm{L}$ de sulfeto não-ionizado, $\mathrm{H}_{2} \mathrm{~S}$, em $\mathrm{pH} 7,6$ - 8,0), enquanto a conversão de $\mathrm{H}_{2} / \mathrm{CO}_{2}$ a metano foi favorecida.

\subsubsection{Avaliação da eficiência e estabilidade do reator termofílico ao longo das fases experimentais}

O comportamento do reator quanto à concentração de matéria orgânica como DQO, assim como a eficiência de remoção de DQO no efluente, durante todas as fases experimentais em condições termofílicas está apresentado na Figura 5.30. 


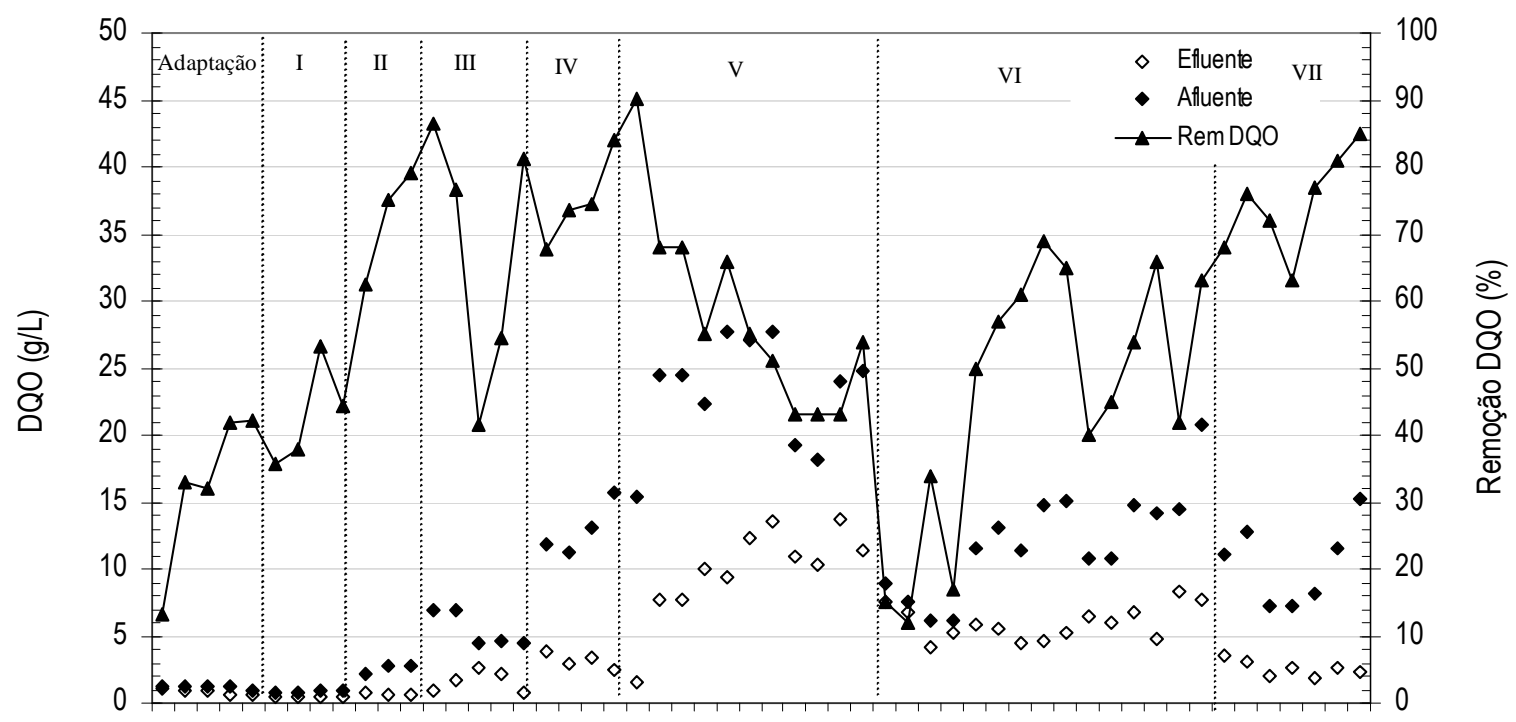

$20 \quad 23 \quad 3944 \quad 48 \quad 68 \quad 71 \quad 8394 \quad 99101103105111114117124128130138144156161169181184191$

Ciclos

Figura 5.30 - Resultados do monitoramento da DQO afluente e efluente e eficiência de remoção de DQO no efluente durante todas as fases experimentais em condições termofílicas.

Observa-se que, ao início de cada fase, quando se aumentava a concentração de vinhaça afluente, a eficiência de remoção de DQO diminuía. Esse comportamento pode ter ocorrido devido a interferências das condições operacionais da fase anterior. Carmo (2004) também observou menores eficiências de remoção em reator UASB correspondente ao período imediatamente após o aumento súbito da DQO afluente, tanto em condições mesofílicas $\left(35 \pm 2{ }^{\circ} \mathrm{C}\right)$ como termofílicas $\left(55 \pm 2{ }^{\circ} \mathrm{C}\right)$, para tratamento de efluente sintético de polpa celulósica.

A variação dos parâmetros de fundamental importância no monitoramento de reatores anaeróbios, $\mathrm{pH}, \mathrm{AVT}$ e AB, ao longo do tempo, encontram-se nas Figuras 5.31, 5.32 e 5.33 , respectivamente. 


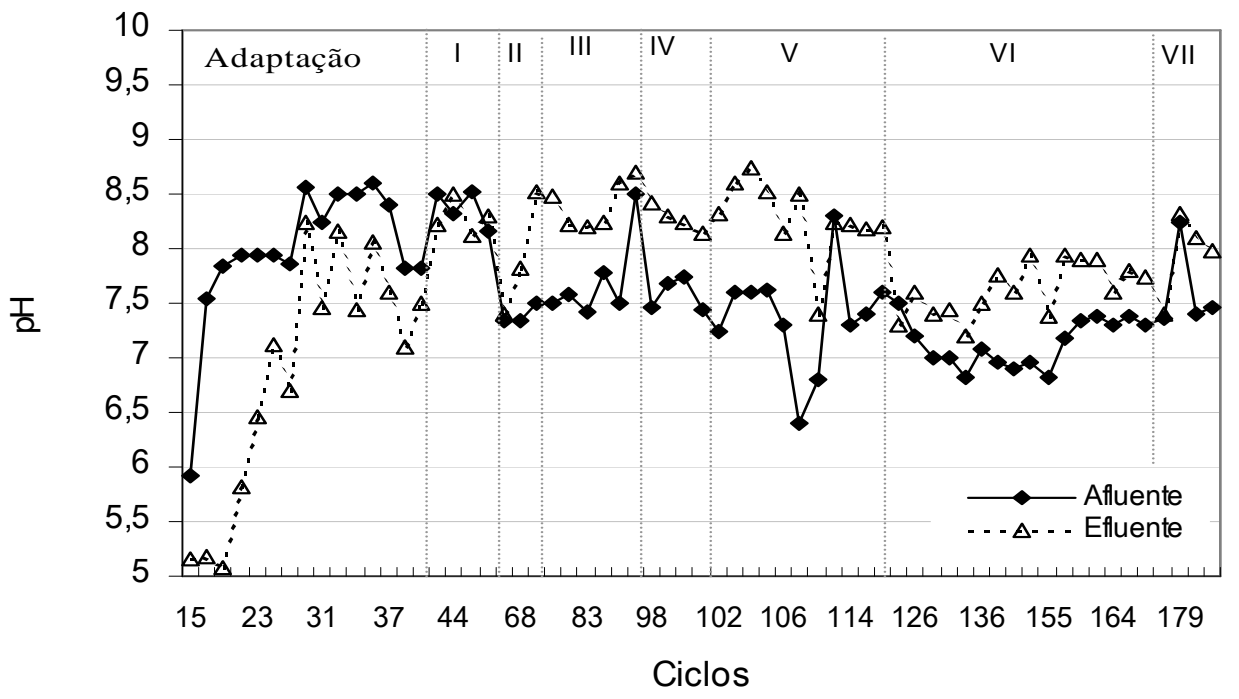

Figura 5.31 - Resultados do monitoramento do $\mathrm{pH}$ afluente e efluente durante todas as fases experimentais em condições termofílicas.

$\mathrm{Na}$ fase de adaptação após suplementação de bicarbonato, observa-se que o pH estava entre 6,5 a 7,5 do ciclo 20 até 29 . Com aumento de $35{ }^{\circ} \mathrm{C}$ para $55{ }^{\circ} \mathrm{C}$ no ciclo 21 , aliado à maior suplementação de bicarbonato (da ordem de $1,2 \mathrm{HCO}_{3}{ }^{-} / \mathrm{DQO}$ ), houve um aumento de 0,5 unidade de $\mathrm{pH}$, chegando em 8,3 no ciclo 30 . Nas fases seguintes, o $\mathrm{pH}$ medido manteve-se acima de 8,0 unidades mesmo após a redução da relação entre bicarbonato e DQO.

Tripathi \& Allen (1999) observaram tendência de aumento do $\mathrm{pH}$ em temperaturas maiores. Verificaram que os resultados de $\mathrm{pH}$ efluente aumentaram cerca de 1,5 unidades de $\mathrm{pH}$ para amostras retiradas de reatores nas condições mesofílicas e termofílicas $\left(35^{\circ} \mathrm{C}, 45{ }^{\circ} \mathrm{C}, 55{ }^{\circ} \mathrm{C}\right.$ e $\left.60{ }^{\circ} \mathrm{C}\right)$.

A partir da segunda fase, mesmo após diminuição do $\mathrm{pH}$ afluente devido à redução na suplementação de bicarbonato e mesmo depois do aumento de carga entre cada fase, pôde-se observar, Figura 5.31, que o pH efluente sempre foi maior que o $\mathrm{pH}$ de entrada, indicando equilíbrio entre as populações que refletiram na boa estabilidade do sistema devido à produção de compostos tamponantes como bicarbonato e/ou consumo dos ácidos voláteis que refletem nos valores de pH (Figura 5.32) . 


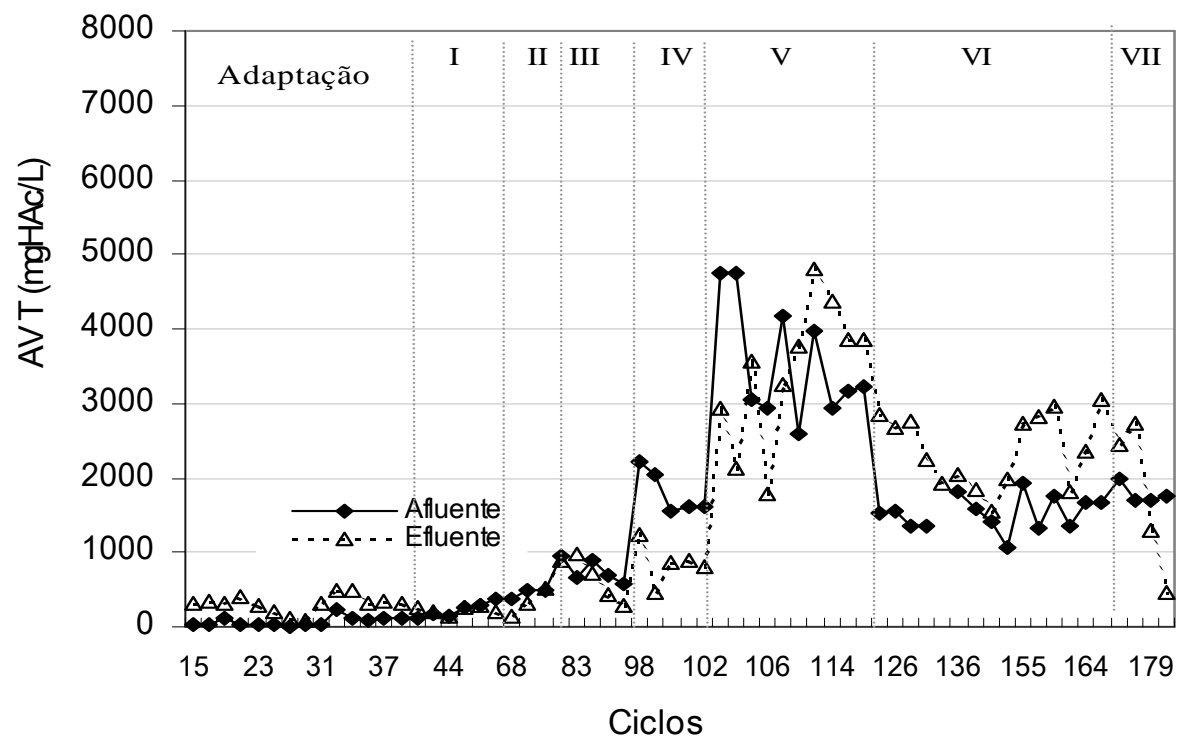

Figura 5.32 - Resultados do monitoramento dos ácidos voláteis totais durante todas as fases experimentais em condições termofílicas.

A instabilidade de consumo dos ácidos voláteis se iniciou na fase $\mathrm{V}$ (20 gDQO/L), quando a concentração de ácidos voláteis chegou a atingir valores em torno de $5000 \mathrm{mg} / \mathrm{L}$. A oscilação se prolongou até a metade da fase VII, quando o reator começou a dar sinais de recuperação, observando-se o decaimento de ácidos.

No trabalho de Carmo (2004), a instabilidade com relação à concentração de ácidos graxos voláteis foi evidenciada principalmente na fase termofílica, em que, provavelmente, houve excesso na concentração de ácidos orgânicos que levou à acidificação do reator UASB e, conseqüentemente, ocorreu o desbalanceamento de atividade entre as comunidades microbianas.

Para os microrganismos com um longo tempo de geração, tais como metanogênicas acetotróficas ou microrganismos consumidores de ácidos graxos voláteis como butirato e propionato, um tempo maior é necessário para desenvolver populações suficientes, comparadas ao rápido crescimento das bactérias hidrolíticas e fermentativas que produzem ácidos graxos voláteis e hidrogênio (AHRING, 1994). Justifica-se, assim, a necessidade de se analisar o tempo de ciclo mais adequado, de forma que não restem, no efluente, concentrações muito altas de ácidos propiônico e butírico.

Observa-se claramente que, até meados da fase V, o reator apresentava bons resultados de adaptação, como menor quantidade de AVT no efluente que no afluente, como visto na Figura 5.32, e maior valor de alcalinidade a bicarbonato (Figura 5.33). 


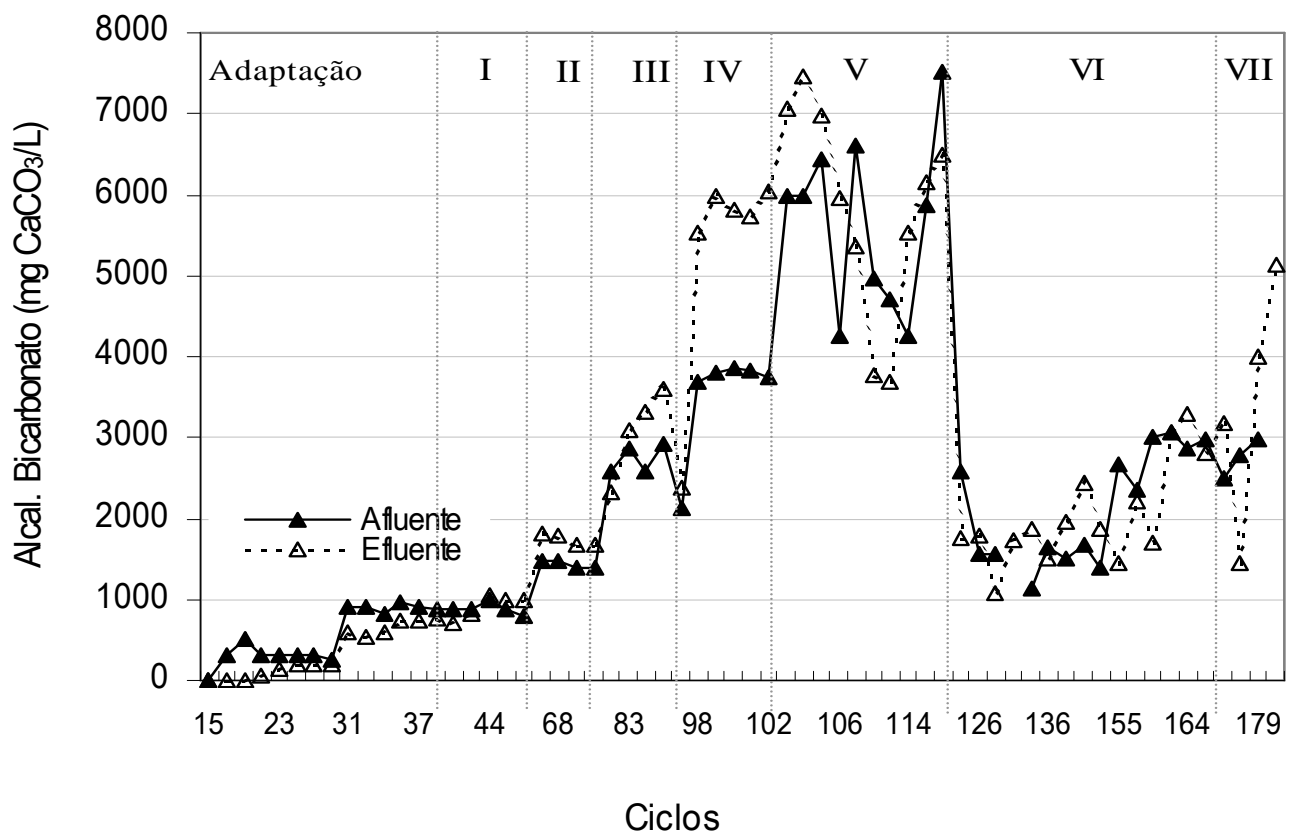

Figura 5.33 - Resultados do monitoramento da alcalinidade a bicarbonato durante todas as fases experimentais em condições termofílicas.

$\mathrm{O}$ colapso total do reator não foi atingido na fase $\mathrm{V}$ devido à suplementação de alcalinidade afluente e devido ao longo tempo de ciclo de 6 dias, que proporcionou produção de alcalinidade a bicarbonato efluente, no ciclo 114, com tendência de aumento.

A estratégia de diminuir a concentração orgânica na fase VI foi positiva, pois colaborou com a recuperação do sistema e diminuição dos ácidos voláteis totais.

Tendência à estabilidade quanto à alcalinidade a bicarbonato adicionada e/ou formada durante o processo anaeróbio (representado pela alcalinidade parcial, AP, na Figura 5.34) e devido à alcalinidade por sais de ácidos orgânicos (Figura 5.35), foi observada até a fase IV, em que a relação AI/AP se aproximou a 0,3 (Figura 5.36) conforme valor obtido no trabalho desenvolvido por Ripley et al. (1986) sobre tratamento anaeróbio de dejetos de aves. 


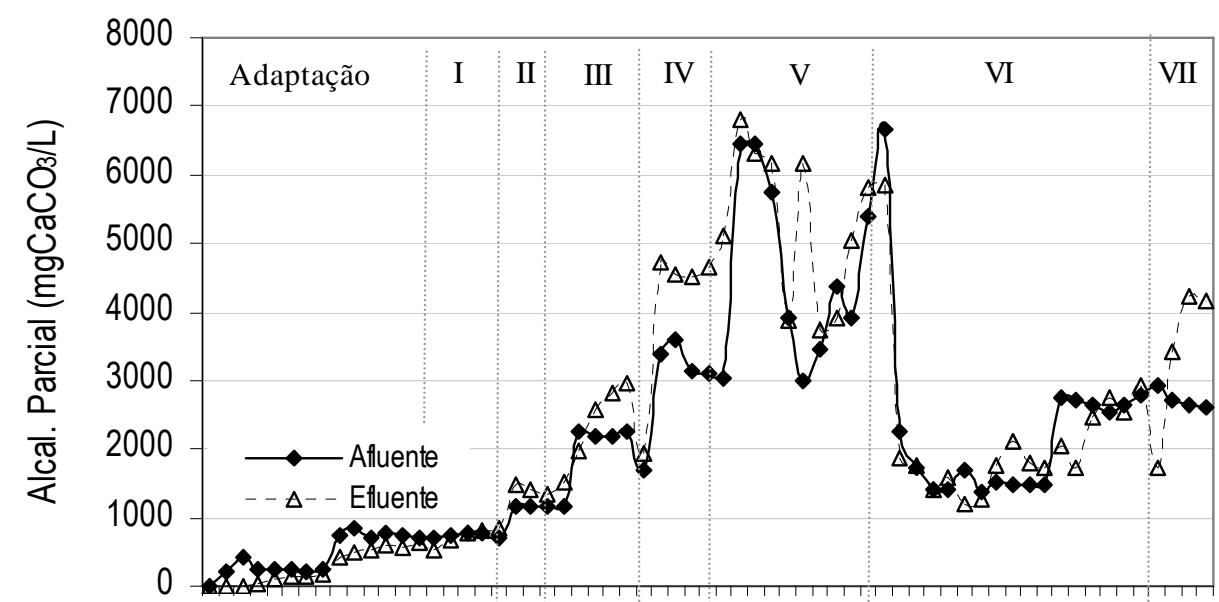

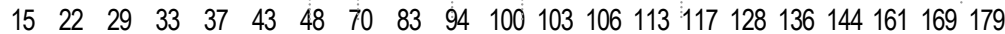

Ciclos

Figura 5.34 - Resultados do monitoramento da alcalinidade parcial durante todas as fases experimentais em condições termofílicas.

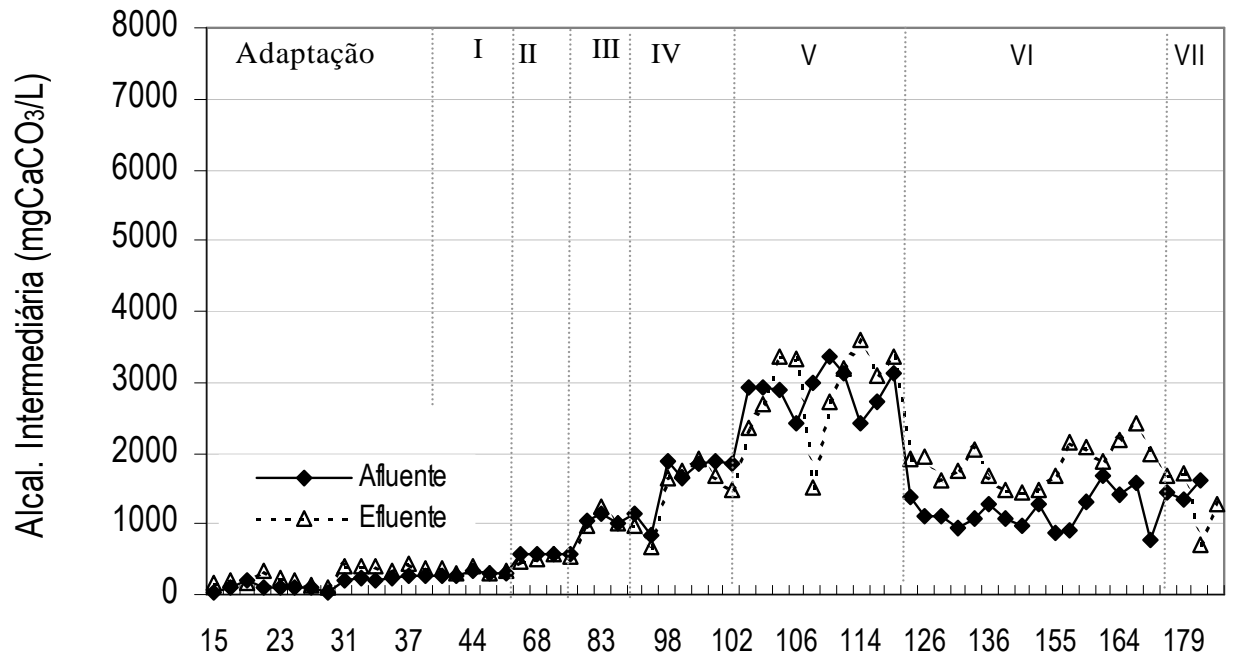

Ciclos

Figura 5.35 - Resultados do monitoramento da alcalinidade intermediária durante todas as fases experimentais em condições termofílicas.

Novamente, a instabilidade foi verificada com base nesses parâmetros na fase V, sendo que na fase VI, ciclo 131, a relação AI/AP atingiu 1,7 sinalizando grande quantidade de sais de ácidos orgânicos $(2041 \mathrm{mg} \mathrm{CaCO} / \mathrm{L}$ medido como alcalinidade intermediária) em relação ao bicarbonato disponível para tamponamento do reator (1201 $\mathrm{mg} \mathrm{CaCO}_{3} / \mathrm{L}$ como alcalinidade parcial). 


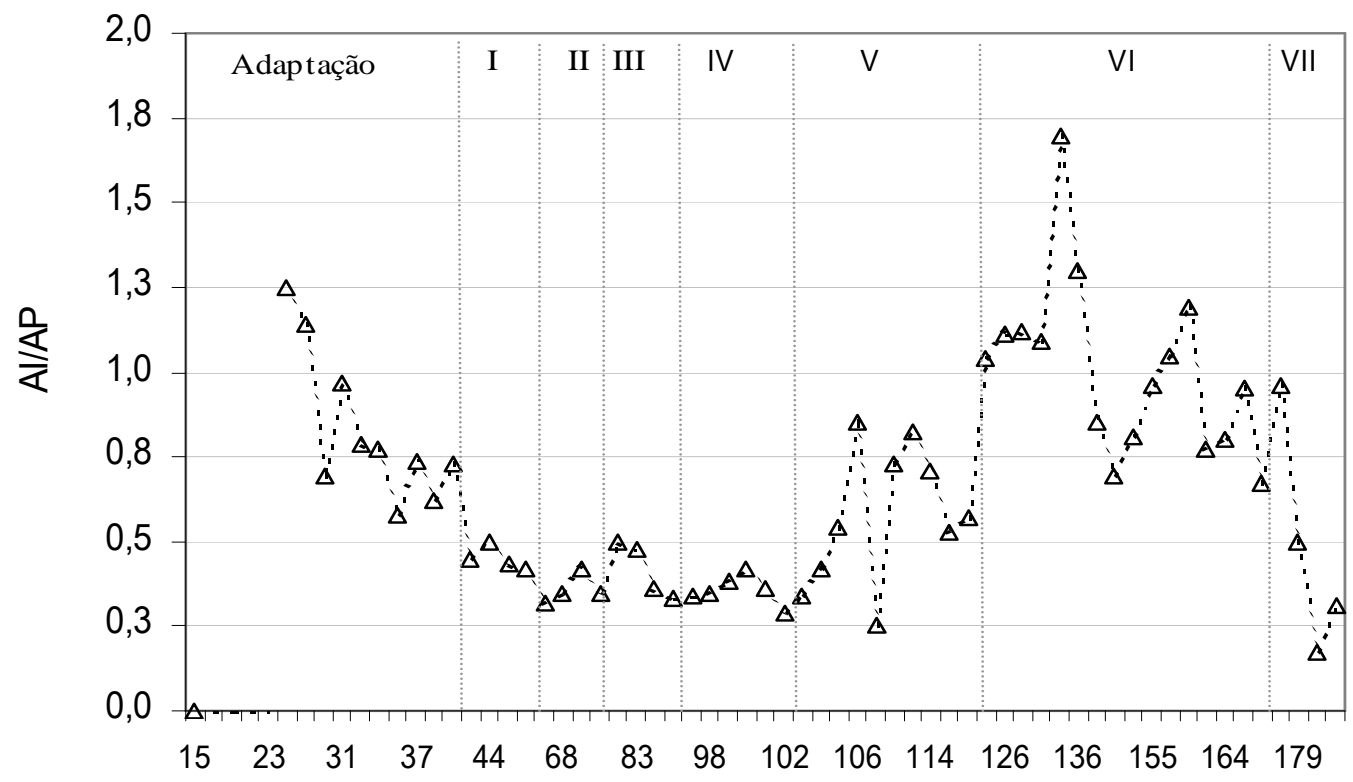

Ciclos

Figura 5.36 - Monitoramento da relação alcalinidade intermediária e parcial (AI/AP) durante todas as fases experimentais em condições termofílicas.

\subsubsection{Aspectos microbiológicos da biomassa imobilizada no reator termofílico ao longo das fases experimentais}

Exames microscópicos das matrizes de espuma de poliuretano usadas como suporte da biomassa ao longo do tempo, permitiram monitorar a dinâmica de formação de biofilme e a colonização frente ao aumento gradativo da concentração de vinhaça, bem como conhecer os microrganismos envolvidos no tratamento anaeróbio termofílico da vinhaça de cana-de-açúcar.

A incidência de morfologias observadas por microscopia ótica, ao longo das fases experimentais, foi quantificada de acordo com a freqüência dos microrganismos em cada intervalo amostrado e foram classificadas como abundante, freqüente, pouco freqüente, raro e não observado (Tabela 5.10).

Desde o início da fase V, observou-se grande perda de biomassa no efluente, como SVT, em cerca de 5,8 g/L. Essa perda foi atribuída, principalmente, ao repentino aumento de concentração (como DQO) de vinhaça da fase anterior que era de $10 \mathrm{~g} / \mathrm{L}$ para 20 g/L. Carmo (2004) observou perda de SVT no reator anaeróbio de $854 \mathrm{mg} / \mathrm{L}$, ocasionada pelo aumento súbito da DQO afluente de 1,3 para 1,8 g/L. Outros autores 
também verificaram perda de biomassa, não só por ocasião de variação de carga orgânica, mas de aumento de temperatura operacional.

$\mathrm{Na}$ primeira fase, foi observado que algumas morfologias semelhantes à Methanosaeta apresentavam vacúolos e bacilos curvos (vibrios) como Dessulfobribio, que são estruturas semelhantes à bactéria redutora de sulfato. Na parte inferior do reator, observou-se material inerte abiótico fluorescente sob luz ultravioleta (Figura 5.37a).

Tabela 5.10 - Incidência de morfologias observadas durante as fases experimentais em ASBBR sob condições termofílicas.

\begin{tabular}{|c|c|c|c|c|c|c|c|c|c|c|c|c|c|c|c|}
\hline \multirow{3}{*}{ Morfologias semelhantes } & \multicolumn{14}{|c|}{ Fases experimentais - Pontos de amostragem* } & \\
\hline & \multicolumn{3}{|c|}{$\mathrm{I}$} & \multicolumn{2}{|c|}{ II } & \multicolumn{3}{|c|}{ III } & \multicolumn{2}{|c|}{ IV } & \multicolumn{3}{|c|}{$\mathrm{V}$} & \multicolumn{2}{|l|}{ VII } \\
\hline & $\mathrm{S} \quad \mathrm{N}$ & $\overline{M H}$ & & $\overline{S M}$ & $\mathrm{~F}$ & $\mathrm{~S} \mathrm{I}$ & $\overline{\mathrm{M}}$ & $\mathrm{F}$ & $\mathrm{SN}$ & $\mathrm{F}$ & $\mathrm{S}$ & $\mathrm{M}$ & $\mathrm{F}$ & S M F & $\mathrm{F}$ \\
\hline \multicolumn{16}{|l|}{ Domínio Eukarya } \\
\hline Coco-bacilos & - & - & & $\mathrm{F} R$ & & - & $\mathrm{R}$ & - & - & $\mathrm{R}$ & - & A & & $-\mathrm{R}$ & \\
\hline Bacilos & A A & A $\mathrm{F}$ & & $\mathrm{F} A$ & $\mathrm{~F}$ & $\mathrm{P}$ & $\mathrm{P}$ & $\mathrm{F}$ & A A & $\mathrm{A}$ & A & $\mathrm{A}$ & $\mathrm{A}$ & $\mathrm{F} F$ & $\mathrm{~F}$ \\
\hline Filamentos & $-\quad R$ & $\mathrm{R} \quad \mathrm{F}$ & & $-\quad-$ & $\mathrm{P}$ & $\mathrm{R}$ & $\mathrm{R}$ & $\mathrm{P}$ & $\mathrm{F} \quad \mathrm{F}$ & $\mathrm{F}$ & $\mathrm{P}$ & $\mathrm{P}$ & $\mathrm{R}$ & $\mathrm{R}$ & $\mathrm{P}$ \\
\hline \multicolumn{16}{|l|}{ Domínio Archaea } \\
\hline Methanosaeta & $\mathrm{F} \quad \mathrm{F}$ & $\mathrm{F}$ & & $\mathrm{F} P$ & & $\mathrm{P}$ & $\mathrm{F}$ & $\mathrm{F}$ & $\mathrm{F} \quad \mathrm{F}$ & $\mathrm{F}$ & $\mathrm{R}$ & $\mathrm{P}$ & & $\begin{array}{lll}\mathrm{R} & \mathrm{R} & \mathrm{F}\end{array}$ & \\
\hline Methanosarcina & - & A $\mathrm{F}$ & & $\mathrm{F}$ & $\mathrm{P}$ & $\mathrm{F}$ & $\mathrm{F}$ & A & $\mathrm{P} A$ & $\mathrm{~A}$ & $\mathrm{R}$ & $\mathrm{F}$ & A & A A & A \\
\hline Bacilos fluorescentes & - & $\mathrm{R}$ & & - & $\mathrm{F}$ & A & & $\mathrm{A}$ & $-\quad-$ & - & & A & A & $\mathrm{F} \mathrm{F}$ & $\mathrm{F}$ \\
\hline Bacilo curvo (BRS) & - & $\mathrm{P}$ & & - & $\mathrm{P}$ & $\mathrm{R}$ & $\mathrm{R}$ & $\mathrm{R}$ & - & $\mathrm{P}$ & $\mathrm{P}$ & $\mathrm{F}$ & A & $\mathrm{P}$ & $\mathrm{P}$ \\
\hline \multicolumn{16}{|l|}{ Outros } \\
\hline Saccharomyces cereavise & $\mathrm{F}$ & $\mathrm{F}$ & & $\mathrm{F} \quad \mathrm{F}$ & $\mathrm{F}$ & $\mathrm{F}$ & A & $\mathrm{A}$ & $\mathrm{P}$ & $\mathrm{F}$ & & $\mathrm{A}$ & $\mathrm{F}$ & $\mathrm{P} \quad \mathrm{F}$ & \\
\hline
\end{tabular}

*Pontos de amostragem da biomassa do reator: $\mathrm{S}$ - superfície, $\mathrm{M}$ - meio, $\mathrm{F}$ - fundo.

Incidência: (A) Abundante, (F) Freqüente, (P) Pouco freqüente, (R) Raro, (-) Não Observado.

As leveduras seguiram freqüentes na fase II, inclusive foram observadas estruturas que pareciam estar se multiplicando por brotação (Figura 5.37c). As morfologias semelhantes à Methanosaeta também se apresentavam com vacúolos (Figura 5.37d e i).

Na fase III, 5g/L, foi observado abundância de Methanosarcina e de bacilos fluorescentes ao longo de todo reator (Figura 5.37 e, f e g, respectivamente). Na parte inferior, houve o aparecimento de morfologias semelhantes a bactérias fotoanóxicas, pois o fundo do reator não era coberto e pode ter proporcionado um pouco de entrada de luz (Figura $5.37 \mathrm{~h})$. 


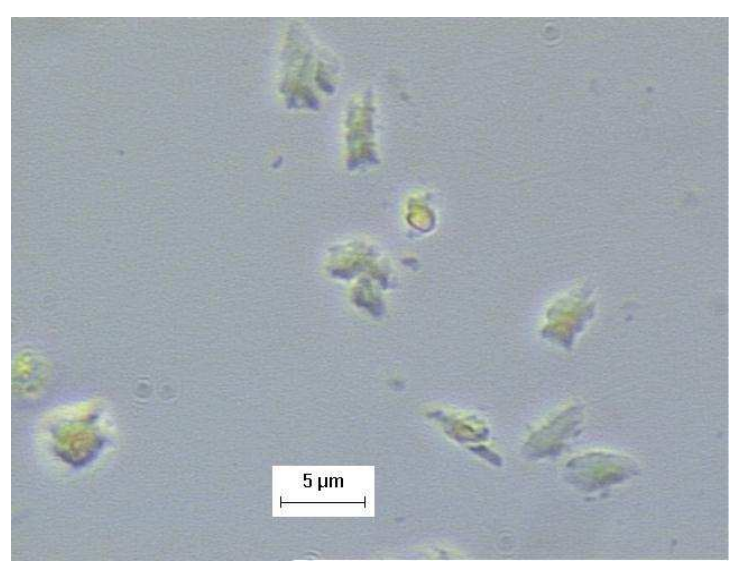

(a)

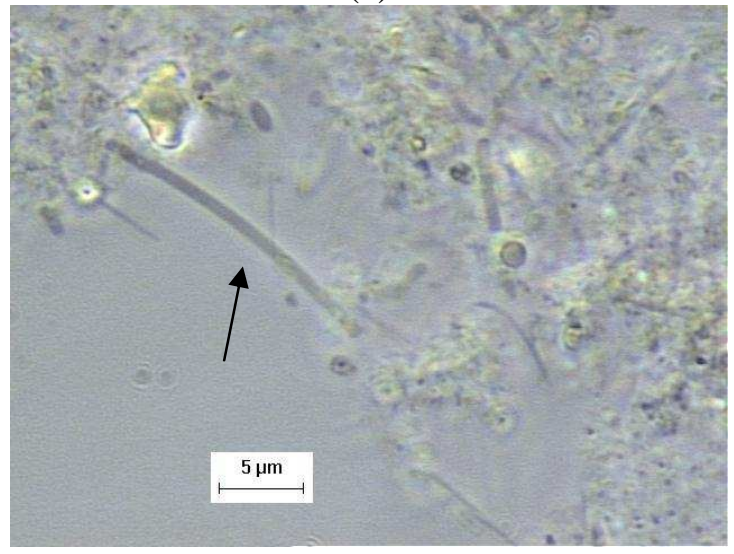

(c)

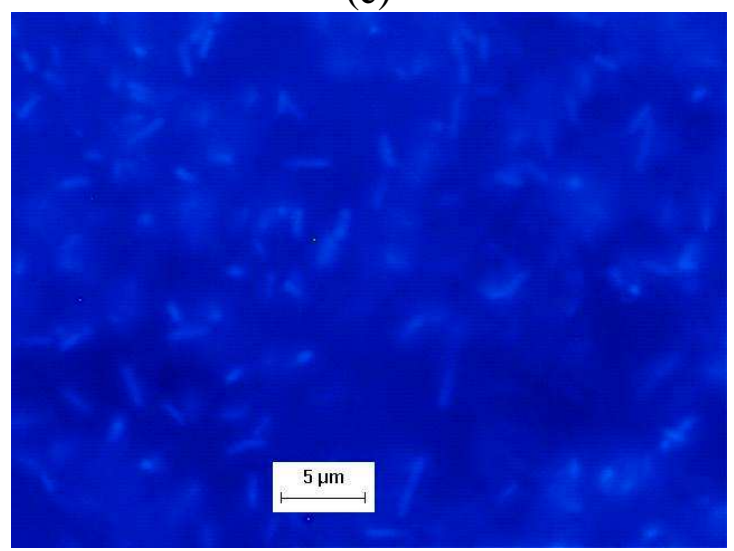

(e)

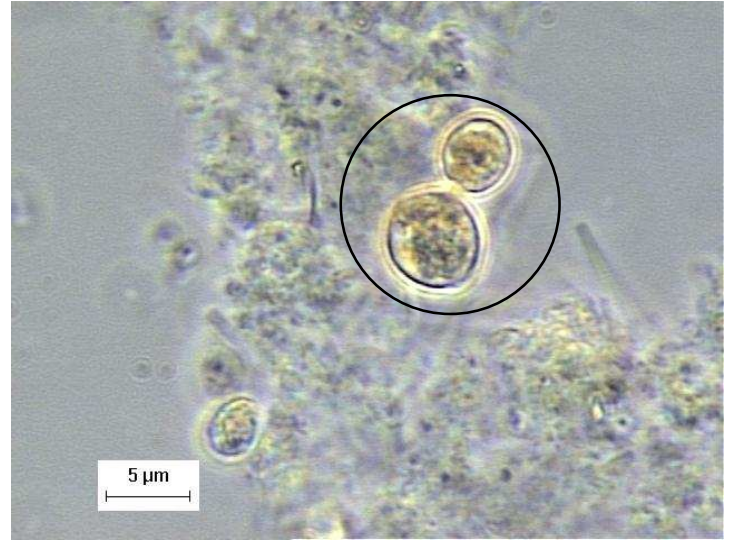

(b)

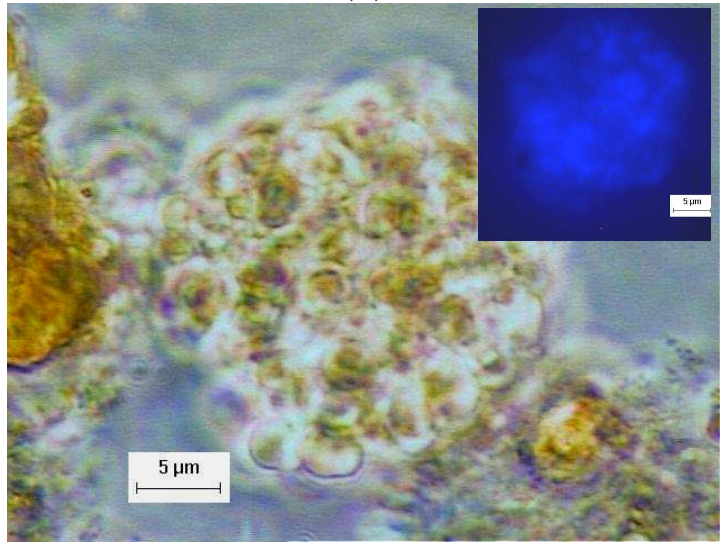

(d)

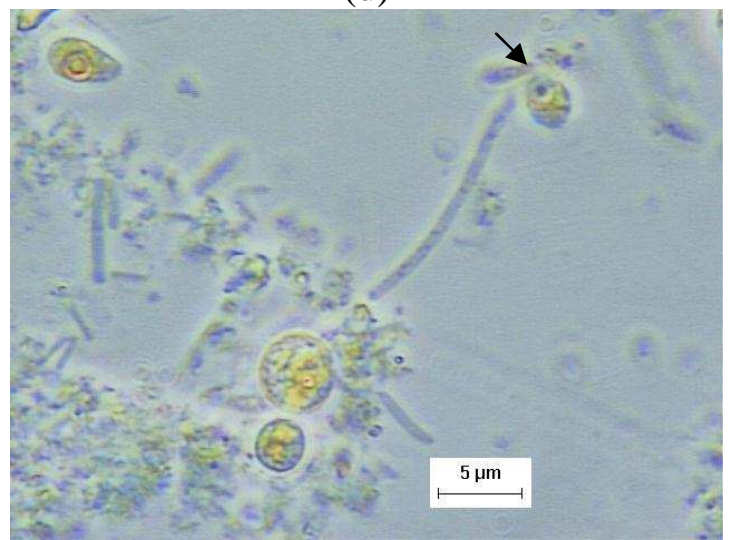

(f)

Figura 5.37 - Morfologias observadas por microscopia óptica de contraste de fases e fluorescência com aumento de 1500X: (a) material inerte e (b) levedura em brotação, (c) células semelhantes à Methanosaeta (seta) em meio a bacilos e cocos, (d) células semelhantes à Methanosarcina e em detalhe a fluorescência de d, (e) bacilos fluorescentes, (f) células semelhantes a fotoanóxicas (seta) e Methanosaeta.

$\mathrm{Na}$ fase IV, com o aumento da concentração de vinhaça para $10 \mathrm{~g} / \mathrm{L}$, de DQO, observou-se que as morfologias mais comuns ao longo do reator foram leveduras, grande diversidade de bacilos de diversas formas e células semelhantes à Methanosaeta (Figura 5.38a). No meio e fundo do reator, teve início o aparecimento abundante de 
Methanosarcina e diminuição de leveduras. Também foi observada grande quantidade de material precipitado, possivelmente enxofre elementar (Figura 5.38b).

$\mathrm{Na}$ fase seguinte, $\mathrm{V}$ com $20 \mathrm{gDQO} / \mathrm{L}$, foi observado grande quantidade de bacilos de diversas formas (finos e compridos, retos, arredondados), bacilos com fluorescência tênue e bacilos semelhantes a bactérias redutoras de sulfato que formavam conglomerados junto com filamentos no fundo do reator. Além desses, foi observado que as leveduras continuavam aparecendo e que, dentre as metanogênicas, havia pouca incidência de Methanosaeta na superfície do reator. As Methanosarcina apareceram do meio para o fundo do reator, com pouca fluorescência e possíveis cistos dessas arquéias. Observou-se que a maior freqüência de arquéias e bacilos fluorescentes ocorria no meio e no fundo do reator, provavelmente maior densidade dos aglomerados, apesar de o reator ter sido projetado para funcionar em mistura completa. Também foi verificado aumento da quantidade de grânulos de material inerte acumulados no meio suporte.

Não foram retiradas amostras da fase VI para observação. Mas, na fase VII, observou-se grande abundância de Methanosarcina fluorescentes, alguns cistos refringentes e bacilos fluorescentes, além de pouca quantidade de leveduras. Observouse, ainda, a presença de bacilos fluorescentes finos e menores, que podem ser associadas às metanogênicas hidrogenotróficas (AHRING, 1994) como, por exemplo, Methanobacterium (Figura 5.38c).

Foram realizados exames microscópicos da biomassa arrastada e foi possível observar a presença de leveduras, bacilos retos e curtos, bacilos arredondados em forma de gota, bacilos fluorescentes, bacilos retos e finos, cocos e morfologias semelhantes à Methanosaeta com vacúolos (Figura 5.38d, e e f).

Provavelmente, o aumento da concentração de vinhaça afluente na fase V para $20 \mathrm{~g} / \mathrm{L}$, levou a um imediato distúrbio do equilíbrio entre fermentativas, produtoras e consumidoras de ácidos envolvidos na metanogênese, pois foi verificado aumento e acúmulo de ácidos graxos voláteis, conforme discutido anteriormente. 


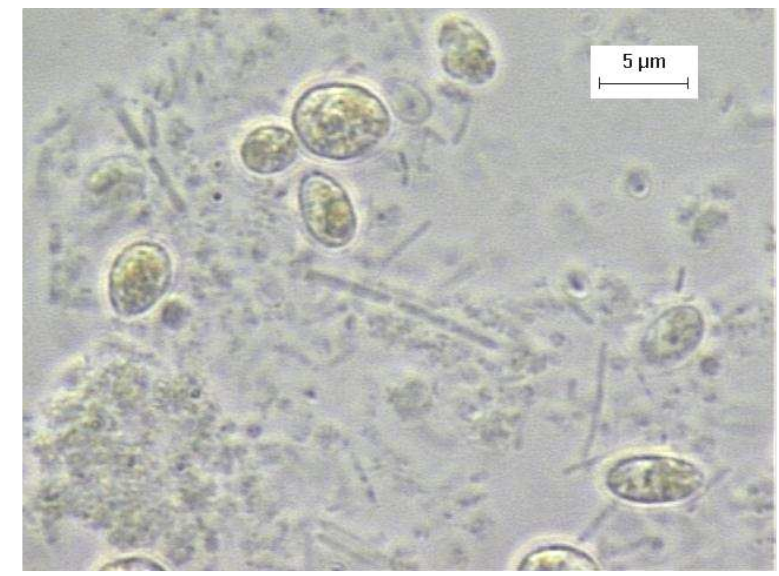

(a)

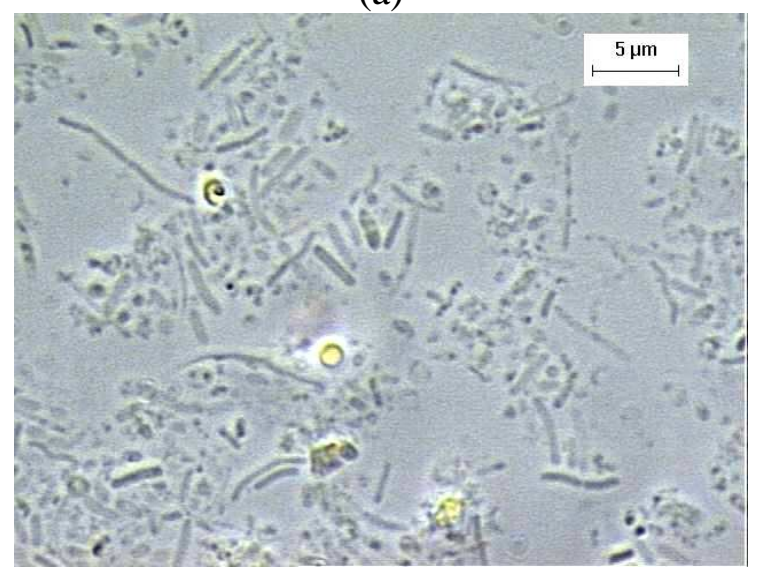

(c)

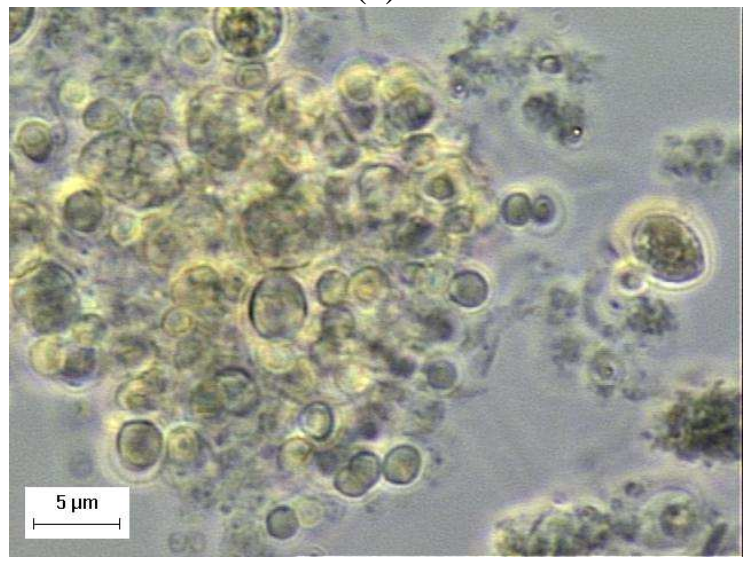

(e)

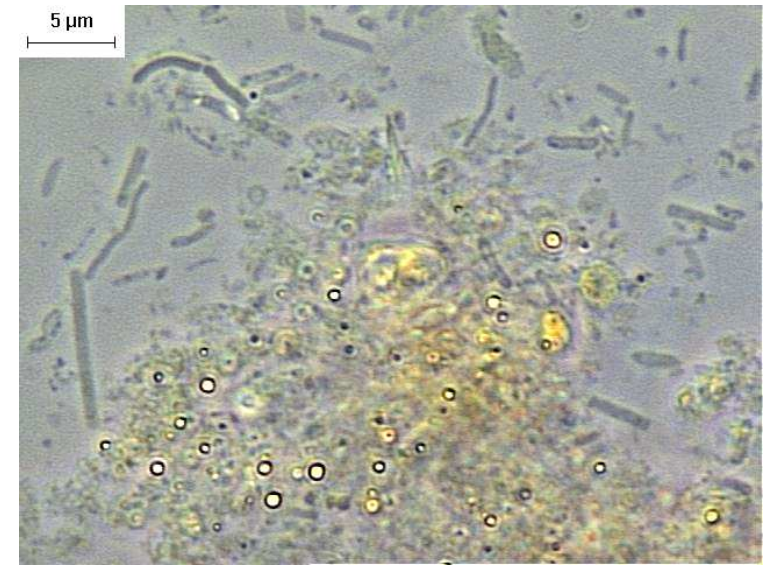

(b)

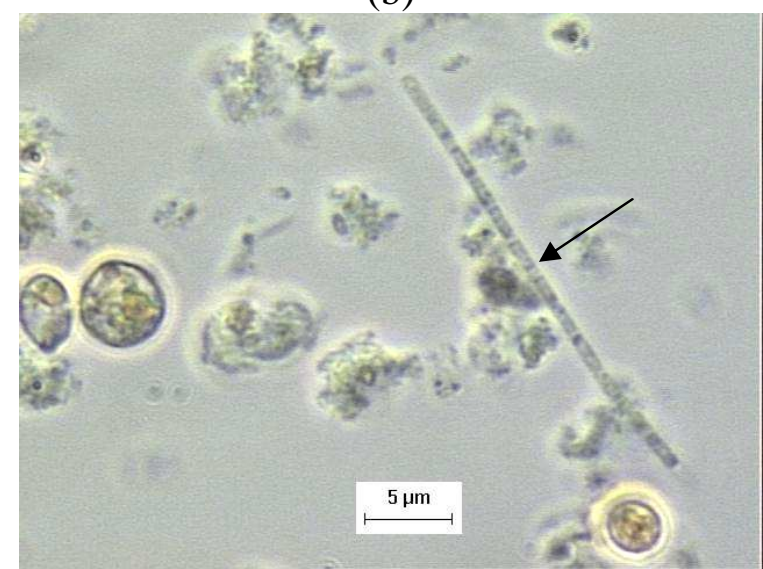

(d)

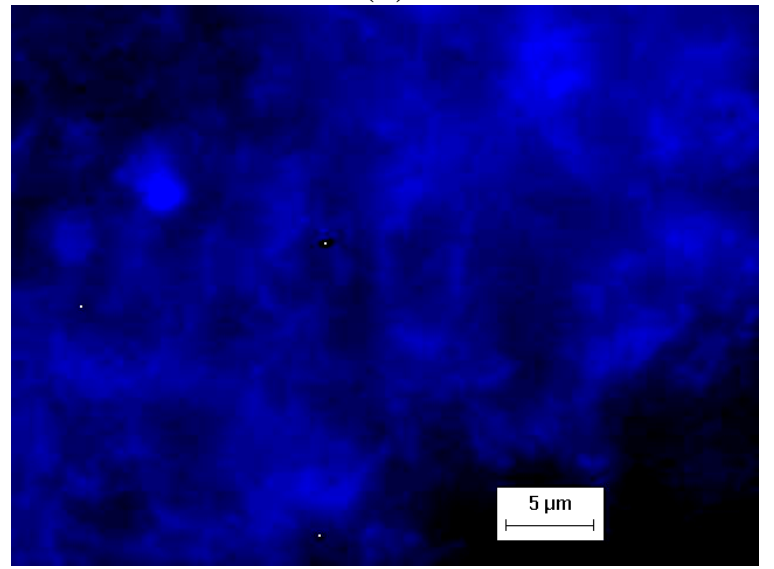

(f)

Figura 5.38 - Morfologias observadas por microscopia óptica de contraste de fases e fluorescência com aumento de 1500X: (a) diversidades de bacilos junto com leveduras e células semelhantes à Methanosaeta, (b) bacilos e grânulos de material precipitado, (c) bacilos hidrogenotróficos, (d) células semelhantes a Methanosaeta vacuolada (seta), (e) cocos e (f) bacilos fluorescentes.

Em síntese, uma grande diversidade de morfologias foi observada em todas as fases experimentais, havendo predominância de bacilos de diversas formas com irregularidades, curvos, retos, arredondados, etc. Foi observada, também, a presença de filamentos e de bactérias em forma de cocos, que podem estar relacionadas com os 
gêneros Clostridium ou Eubacterium, que são importantes durante as fases de hidrólise e fermentação em condições estritamente anaeróbia (SNEATH, 1986).

Dentre as metanogênicas, predominavam inicialmente as células semelhantes à Methanosaeta, com pouca incidência de Methanosarcina. Contudo, as morfologias como Methanosaeta apresentavam vacúolos de gases bem evidentes, característico deste tipo de células. Essa mesma característica foi observada no trabalho de Carmo (2004), em condições termofílicas. Entretanto, a autora não observou tal aparência nas Methanosaeta em condições mesofílicas.

A observação de aumento de freqüência de organismos semelhantes ao gênero Methanosarcina e diminuição da população de Methanosaeta, ao longo do tempo com o aumento da concentração de vinhaça, pode ser explicada pela composição do substrato, pois o predomínio de Methanosarcina é favorecido em alta concentração de ácido acético, por ter maior taxa de utilização específica do acetato, apesar de ter menor afinidade que o gênero Methanosaeta (SPEECE, 1996).

Ahring (1994) também encontrou metanogênicas acetotróficas fluorescentes da família Methanosarcinae em reator UASB operado em temperaturas de 50 a $60{ }^{\circ} \mathrm{C}$ e ressalta que este tipo de microrganismo é típico de reatores em que são aplicadas altas cargas orgânicas que resulta em maior concentração de acetato.

Além disso, van Lier (1995) relatou que arquéias do gênero Methanosarcina têm maior taxa de crescimento máximo $\left(\mu_{\text {máx }}\right)$ tendo acetato como fonte de carbono no substrato em temperatura termofílica que as arquéias do gênero Methanosaeta, conforme apresentado na Tabela 3.2.

A degradação de fenol que foi observada ao longo dos ciclos pode estar relacionada com a grande diversidade de bacilos e de alguns cocos. Bolaños et al. (2001), que avaliaram a degradação de fenol em reator anaeróbio horizontal de leito fixo (RAHLF) sob condições mesofílicas, e constataram, nos exames microscópicos realizados, a existência de relação sintrófica entre os organismos que participam do processo, com predomínio de três grupos morfológicos: coco-bacilos, responsáveis pela oxidação de fenol, Methanosaeta acetoclástica e organismos hidrogenotróficos, provavelmente Methanobacterium, Methanobrevibacter e Methanococcus. É importante destacar que, durante todas as fases de operação, os autores observaram a predominância de Methanosaeta.

O grande potencial de degradação de diversos compostos pelo biofilme formado se deve à imobilização de biomassa em espumas de poliuretano que oferecem 
excelentes condições para crescimento e retenção, favorecendo o fluxo de substratos e produtos (VARESCHE et al., 1997).

A Figura 5.39 mostra algumas fotos feitas em microscopia eletrônica de varredura que permite observar as morfologias em outras dimensões, como por exemplo, as leveduras em brotação, a biomassa aderida nas espumas de poliuretano, a conformação dos bacilos e metanogênicas.

Ao final de cada fase experimental, a estimativa dos sólidos voláteis totais (SVT) realizada serviu como um valor indicativo da quantidade de biomassa imobilizada presente no material suporte. Esses dados estão apresentados na Tabela 5.11 .

Tabela 5.11 - Valores médios de sólidos voláteis totais das espumas de poliuretano obtidos ao final das fases experimentais sob condições termofílicas.

\begin{tabular}{lcccccc}
\hline \multirow{2}{*}{ Parâmetro } & \multicolumn{7}{c}{ Fases } \\
\cline { 2 - 7 } & Adaptação & II & III & IV & V & VII \\
\hline ST (g/g de espuma) & 1,1 & 1,7 & 1,6 & 3,1 & 8,6 & 2,4 \\
SVT (g/g de espuma) & 1,0 & 0,3 & 0,6 & 1,2 & 2,6 & 1,1 \\
SVT/ST & 0,9 & 0,2 & 0,4 & 0,4 & 0,3 & 0,4 \\
S/M* & $0,04-0,12$ & 0,95 & 1,04 & 0,98 & 0,95 & 1,11 \\
\hline
\end{tabular}

* relação substrato/microrganismos em g de DQO/g de SVT.

Nas condições avaliadas, 30 - 45\% (SVT/ST) dos sólidos totais dentro do material suporte (fases III a VII) foram sólidos voláteis, possivelmente biomassa.

Foi observado o aumento gradativo da quantidade de SVT por massa de espuma de poliuretano da fase II até a fase $\mathrm{V}$, quando se constatou o arraste de biomassa efluente devido à alta concentração de substrato, que refletiu em menor quantidade de SVT no suporte na fase VII (Tabela 5.11).

A relação da quantidade de substrato para a quantidade de microrganismo manteve-se em cerca de 1,0, o que pode ter proporcionado condições para que a biomassa se desenvolvesse na medida que era aumentada a concentração do substrato ao longo das fases experimentais.

Cho et al. (2004), trabalhando com diferentes relações substrato-microrganismo com alta quantidade de sólidos em testes de atividade metanogênica específica, sugeriram que sejam utilizadas relações entre 0,4 e 0,6 g DQO/g SSV, pois a partir de 
0,6 não foi observado acréscimo considerável da atividade metanogênica específica que em média foi de 0,56 g DQO/g SSV.d para as relações 0,5, 0,6 e 1,2.

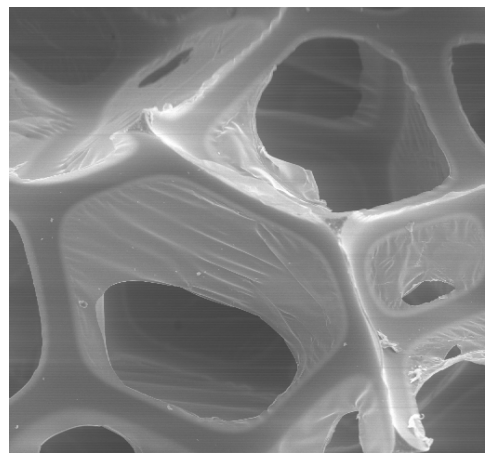

(a)

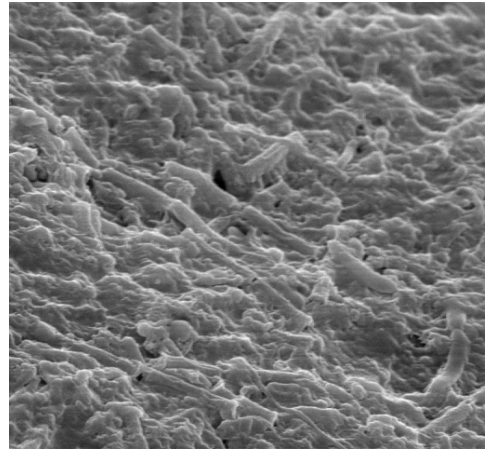

(d)

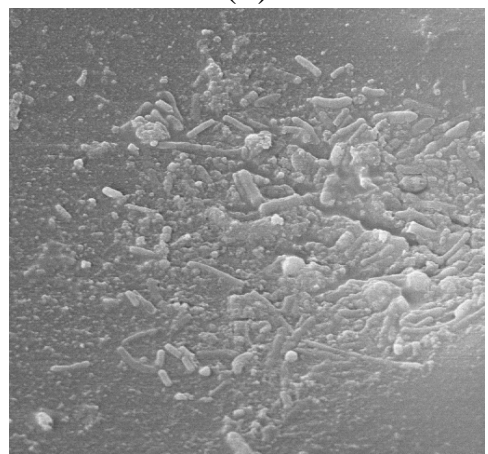

(g)

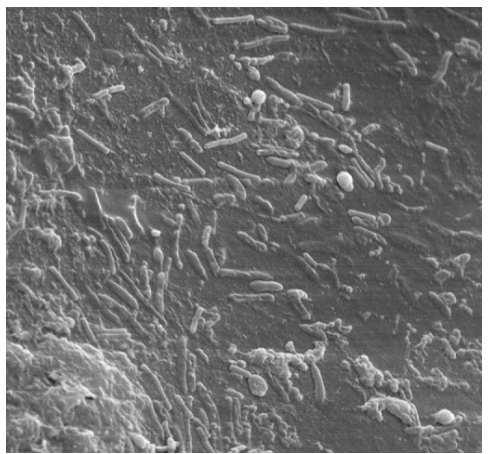

(b)

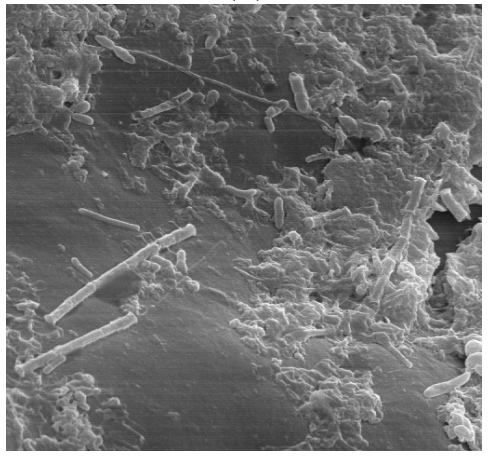

(e)

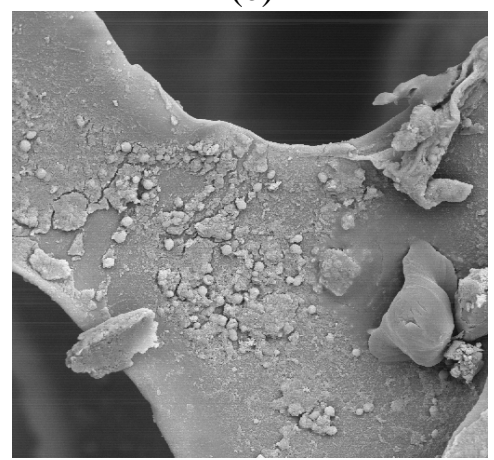

(h)

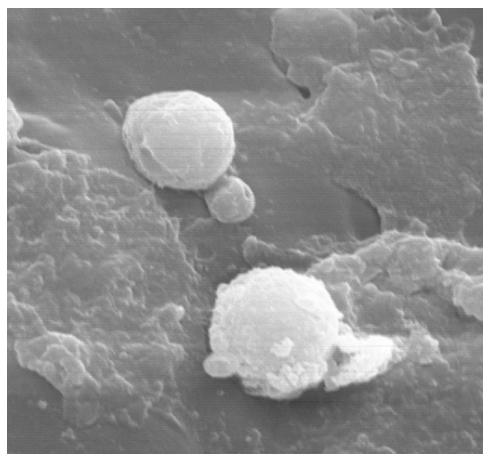

(c)

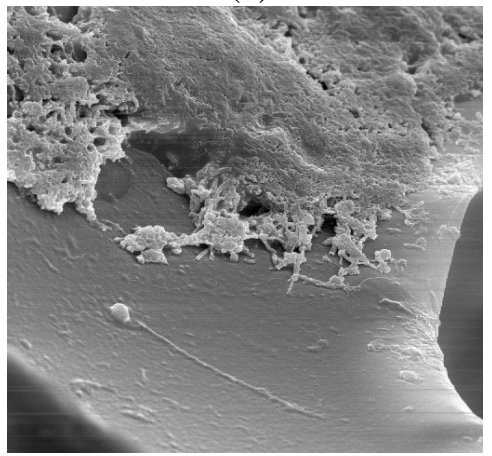

(f)

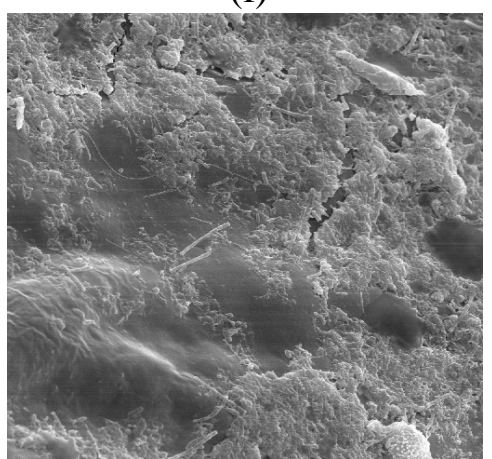

(i)

Figura 5.39 - Morfologias observadas em microscopia eletrônica de varredura: (a) poros da espuma de poliuretano utilizada como meio suporte (aumento 100X), (b) bacilos de diversas formas (aumento 3000X), (c) levedura em brotação (aumento 5000X), (d) semelhante a células Methanosaeta e bacilos (aumento 5000X), (e) bacilos de diversas formas e células semelhantes a Methanosaeta (aumento 3000X), (f) vista da biomassa aderida a espuma (aumento 1000X), (g) células semelhantes a bacilos hidrogenotróficos (aumento 3000X), (h) modo de adesão da biomassa na espuma e leveduras (aumento 500X), (i) cocos, bacilos de diversos tipos e leveduras (aumento 1000X). 
O perfil do DGGE mostrou considerável variação com relação à diversidade microbiana de arquéias e de bactéria entre o inóculo mesofílico e a biomassa termofílica selecionada ao final da fase VII, apresentando coeficiente de similaridade de 0,005\% tanto para o Domínio Bacteria como para o Dominio Archaea, o que significa que as populações mudaram quase que totalmente desde a inoculação. A diversidade de bandas pode ser vista na Figura 5.40.

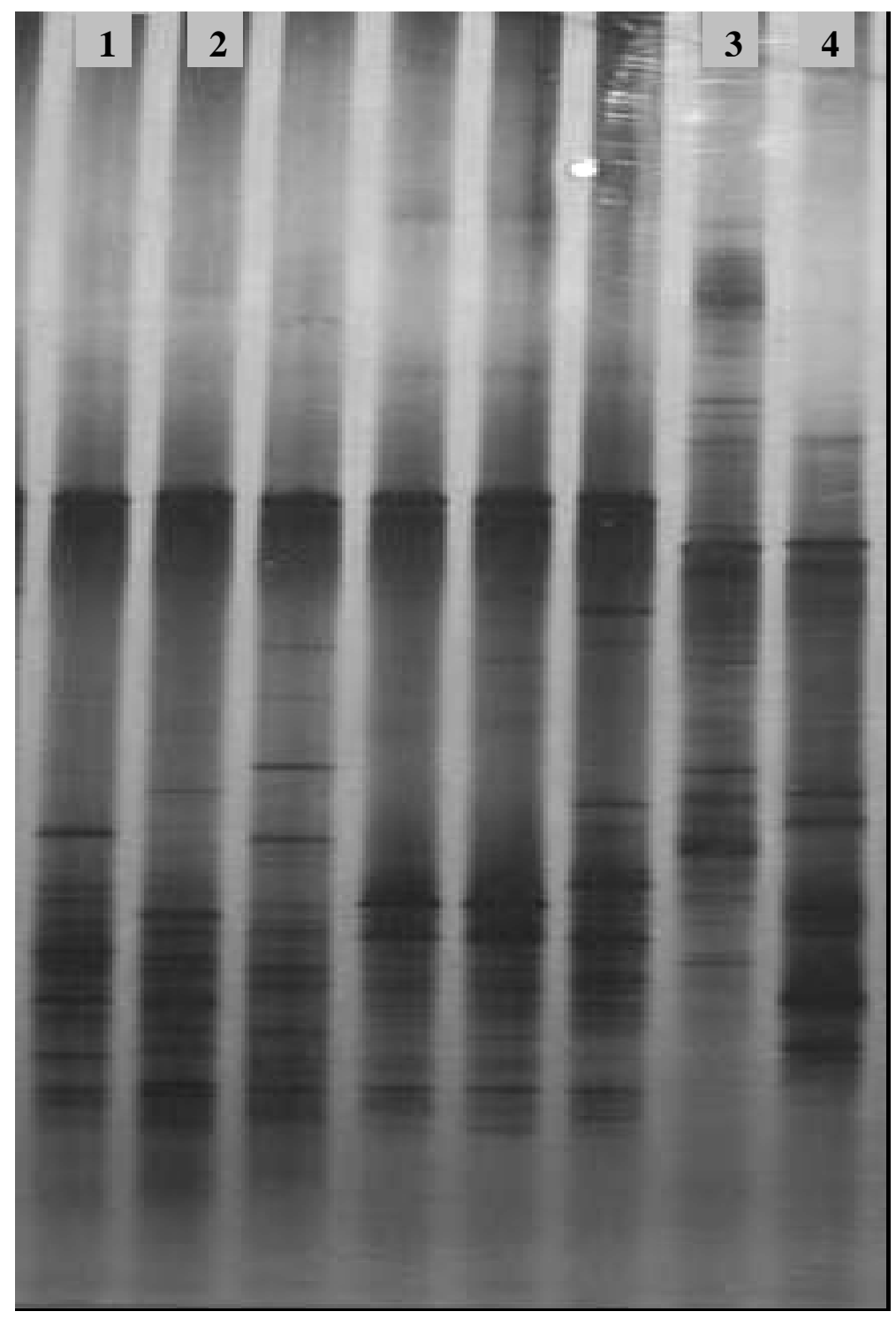

Figura 5.40 - Perfis de DGGE: (1) Domínio Bacteria do inoculo mesofílico, (2) Domínio Bacteria da biomassa termofílica selecionada ao final da fase VII, (3) Domínio Archaea do inoculo mesofílico, (4) Domínio Archaea da biomassa termofílica selecionada ao final da fase VII. Gradiente $20 \%-60 \%$. 


\subsubsection{Determinação dos parâmetros cinéticos aparentes sob condições termofílicas} $\left(55^{\circ} \mathrm{C}\right)$

Os valores dos parâmetros cinéticos aparentes $\left(\mathrm{k}_{1}{ }^{\mathrm{app}}\right)$ e das concentrações residuais de $\mathrm{DQO}$ no efluente $\left(\mathrm{C}_{\mathrm{SR}}\right)$ foram estimados a partir do ajuste de modelo aos dados obtidos dos perfis temporais de DQO em cada fase experimental.

A Tabela 5.12 apresenta os valores obtidos, enquanto a Figura 5.41 mostra as curvas correspondentes ao modelo ajustado aos dados experimentais.

Tabela 5.12 - Parâmetros cinéticos aparentes de decaimento de DQO em cada fase experimental tratando vinhaça de cana-de-açúcar em ASBBR termofílico.

\begin{tabular}{cccccc}
\hline Fase experimental & $\mathrm{COV}^{*}(\mathrm{~g} / \mathrm{L} . \mathrm{d})$ & $\mathrm{C}_{\mathrm{So}} *(\mathrm{~g} / \mathrm{L})$ & $\mathrm{C}_{\mathrm{SR}}(\mathrm{g} / \mathrm{L})$ & $\mathrm{k}_{1}{ }^{\text {app }}\left(\mathrm{h}^{-1}\right)$ & $\mathrm{R}^{2}$ \\
\hline I & 0,85 & 0,85 & $0,41 \pm 0,02$ & $0,194 \pm 0,03$ & 0,89 \\
II & 2,54 & 2,54 & $0,65 \pm 0,09$ & $0,151 \pm 0,02$ & 0,97 \\
III & 3,64 & 5,46 & $1,11 \pm 0,22$ & $0,105 \pm 0,02$ & 0,93 \\
IV & 4,50 & 13,47 & $1,76 \pm 0,67$ & $0,049 \pm 0,01$ & 0,91 \\
VII $^{1}$ & 5,24 & 10,74 & $2,10 \pm 0,56$ & $0,085 \pm 0,03$ & 0,91 \\
\hline
\end{tabular}

${ }^{1}$ média dos perfis realizados nos ciclos 185 e 190; *dados experimentais.

Um ajuste comparativo também foi realizado fixando-se os valores de DQO residual do efluente da amostra retirada no último ponto do perfil (CSR). Entretanto, observou-se que os valores de $\mathrm{R}^{2}$ e de $\mathrm{k}_{1}{ }^{\text {app }}$ obtidos nos ajustes destas curvas foram menores para a maioria dos perfis quando $\mathrm{C}_{\mathrm{SR}}$ também foi estimado.

Como pode ser observado na Tabela 5.12, a constante cinética aparente de primeira ordem $\left(\mathrm{k}_{1}{ }^{\text {app }}\right)$ diminuiu à medida que a $\mathrm{COV}$ e concentração do afluente $\left(\mathrm{C}_{\mathrm{So}}\right)$ aumentou.

Em todas as fases experimentais, o comportamento das curvas quanto à redução de DQO apresentou a mesma tendência, exceto para o perfil da fase IV (Figura 41d), em que houve aumento de DQO nos três últimos pontos amostrados (56, 64 e 72 horas). Portanto, um ajuste aos dados experimentais até o ponto de amostragem de 48 horas foi realizado para comparação. $\mathrm{O} \mathrm{k}_{1}{ }^{\text {app }}$ obtido neste novo ajuste foi de $0,049 \pm 0,007 \mathrm{~h}^{-1} \mathrm{e}$ $\mathrm{C}_{\mathrm{SR}}$ de 1,64 gDQO/L ( $\mathrm{R}^{2}$ 0,90) não diferindo significativamente dos valores obtidos para os mesmos parâmetros considerando-se todos os pontos amostrados (Tabela 5.12). 


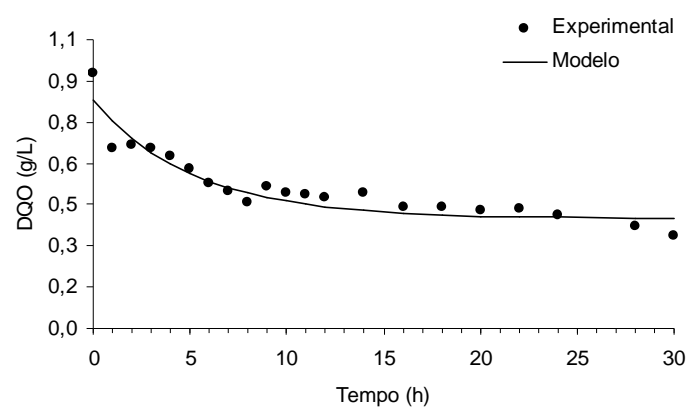

(a)

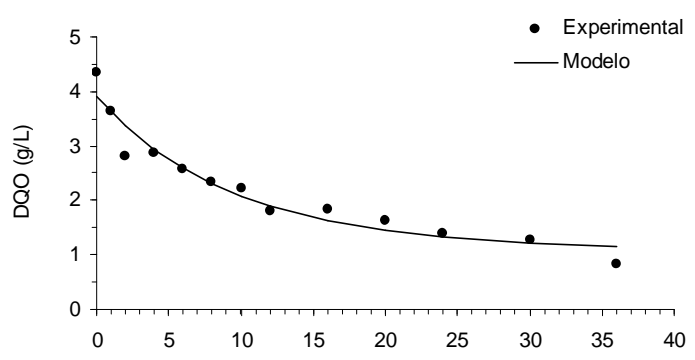

(c)

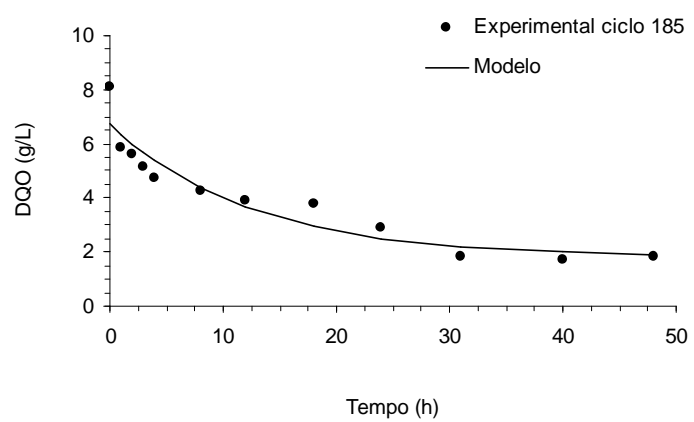

(e)

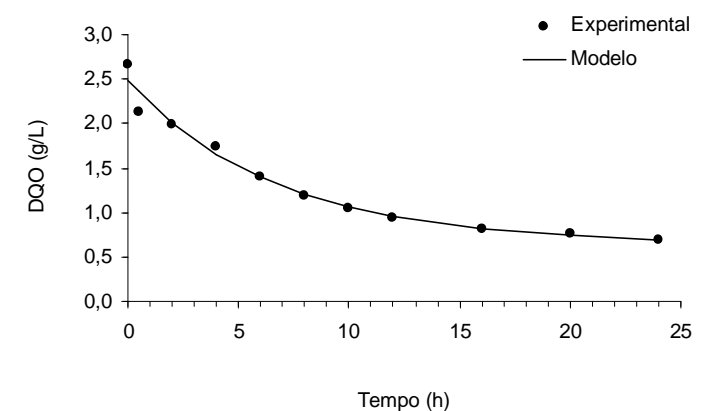

(b)

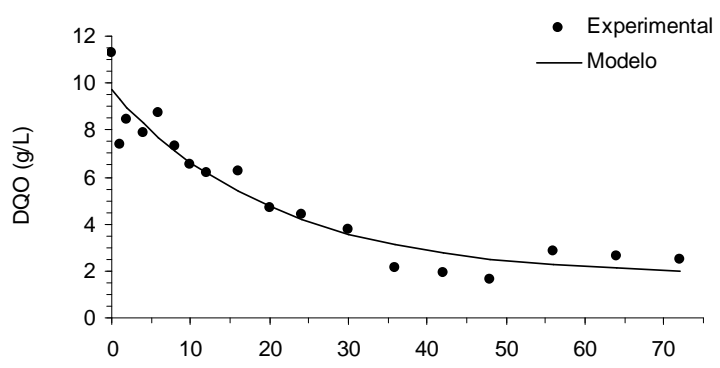

(d)

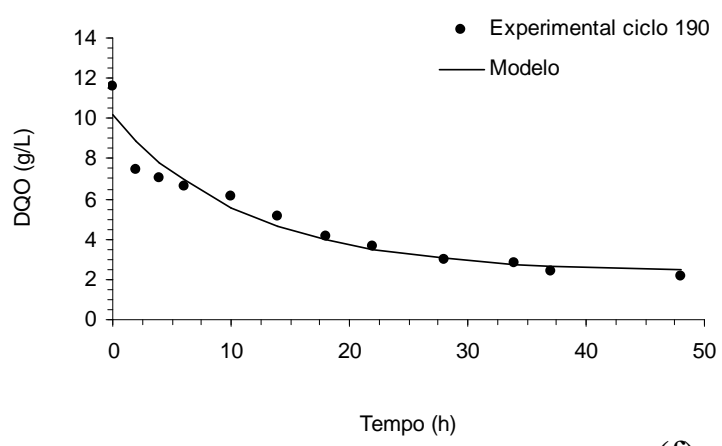

(f)

Figura 5.41 - Ajuste do modelo cinético de primeira ordem aos dados experimentais de decaimento de DQO sob condições termofílicas: (a) fase I - 0,85 gDQO/L.d, (b) fase II - 2,54 gDQO/L.d, (c) fase III - 3,64 gDQO/L.d, (d) fase IV - 4,50 gDQO/L.d, (e) perfil do ciclo 185 - fase VII - 5,24 gDQO/L.d, (f) réplica de (e) - perfil do ciclo 190.

Borges (2003) avaliou a influência da estratégia de alimentação no desempenho do ASBBR operado a $30{ }^{\circ} \mathrm{C}$ e $500 \mathrm{rpm}$ no tratamento de esgoto sintético com $500 \mathrm{mgDQO} / \mathrm{L}$ e verificou a relação entre o tempo de enchimento e o tempo de ciclo do reator na eficiência do reator. Aos dados obtidos nos perfis de redução de DQO realizados o autor ajustou o modelo cinético de primeira ordem em dois procedimentos diferentes: ( $i$ ) estimativa de $\mathrm{k}_{1}{ }^{\text {app }}$ pelo ajuste do modelo aos dados experimentais com $\mathrm{C}_{\mathrm{SR}}$ fixo correspondente ao valor experimental e, (ii) estimativa de ambos, $\mathrm{k}_{1}{ }^{\text {app }}$ e $\mathrm{C}_{\mathrm{SR}}$ pelo ajuste do modelo aos dados experimentais. Com base na correlação entre o modelo de primeira ordem e os valores experimentais e na integral do quadrado dos erros (IQE) 
obtidos, o autor também concluiu que o ajuste do segundo procedimento apresentou melhores valores para os seus dados e minimização do IQE.

\subsection{Ensaios de biomassa anaeróbia com substrato semelhante à vinhaça do processamento de beterraba}

Os resultados apresentados a seguir correspondem aos ensaios realizados na Universidad de Valladolid (Espanha), com reator anaeróbio em bateladas seqüenciais contendo biomassa imobilizada em espumas de poliuretano e em reatores com biomassa granulada suspensa, tratando substrato semelhante à vinhaça proveniente do processamento da beterraba para produção de açúcar. Os ensaios foram realizados para as temperaturas termofílicas e mesofílicas.

\subsubsection{Ensaios com biomassa imobilizada em ASBBR sob condições termofílicas}

Os resultados de DQO obtidos nesta etapa experimental em ASBBR estão na Figura 5.42.

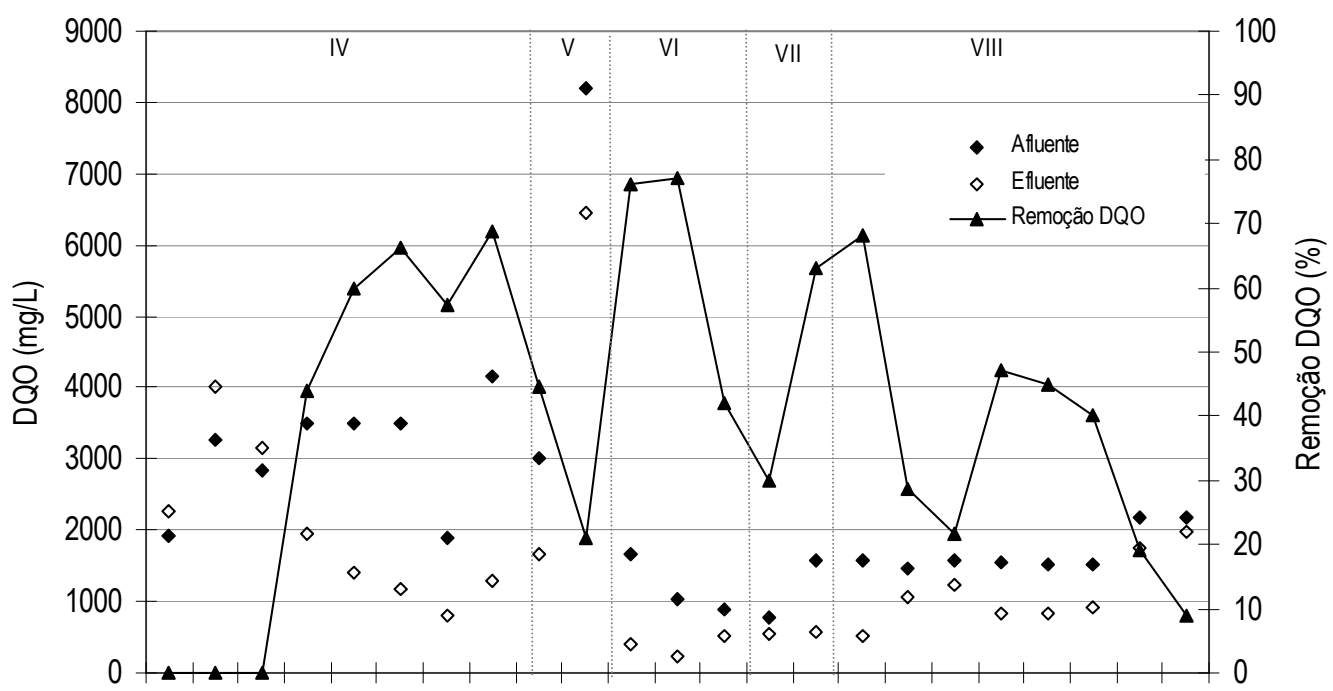

$\begin{array}{lllllllllllllllllllllll}10 & 12 & 14 & 21 & 28 & 31 & 36 & 39 & 40 & 46 & 49 & 50 & 51 & 52 & 57 & 58 & 60 & 61 & 62 & 63 & 70 & 74 & 78\end{array}$

Ciclos

Figura 5.42 - Resultados do monitoramento da DQO afluente e efluente e da eficiência de remoção do reator termofílico ASBBR tratando substrato semelhante à vinhaça do processamento da beterraba. 
Na Tabela 5.13 são apresentados os valores obtidos de DQO afluente e efluente, bem como as eficiências médias obtidas nas fases experimentais analisadas.

Tabela 5.13 - Valores médios de DQO e de eficiência de remoção em reator ASBBR termofílico tratando substrato semelhante à vinhaça de beterraba.

\begin{tabular}{cccc}
\hline \multirow{2}{*}{ Fases } & \multicolumn{3}{c}{ DQO } \\
\cline { 2 - 4 } & Afluente \pm DP* $(\mathbf{m g} / \mathbf{L})$ & Efluente \pm DP* $(\mathbf{m g} / \mathbf{L})$ & Eficiência $(\%)$ \\
\hline IV & $3062,4 \pm 753,4$ & $1971,8 \pm 1031$ & 38 \\
V & 8186,7 & 6453,3 & 21 \\
VI & $1199,7 \pm 441,4$ & $384,7 \pm 139,6$ & 65 \\
VII & $1312,7 \pm 474,5$ & $545,7 \pm 35,1$ & 54 \\
VIII & $1711,5 \pm 313,3$ & $1227,1 \pm 464,5$ & 30 \\
\hline
\end{tabular}

* DP - desvio padrão.

Observa-se que as médias das eficiências alcançadas, em cada fase experimental, foram baixas (Tabela 5.13) e que, segundo a curva indicativa da tendência de eficiência de remoção de DQO (Figura 5.42), houve grande oscilação entre as fases experimentais, o que indica instabilidade do sistema.

Também foram observados valores altos de ácidos orgânicos no efluente nas fases IV e V. No ciclo 14, observou-se $2000 \mathrm{mg} / \mathrm{L}$ de ácidos orgânicos que diminuiu a $345 \mathrm{~m} / \mathrm{L}$ no final da fase IV (ciclo 40). Após o ciclo 48, a DQO de entrada foi diminuída de $8 \mathrm{~g} / \mathrm{L}$ para 1,2 $\mathrm{g} / \mathrm{L}$ e o tempo de ciclo aumentado de 1 para 7 dias na fase VI, na tentativa de melhorar o desempenho do reator. Nesta fase, a eficiência de remoção média atingiu $65 \%$ com tempo de ciclo de 7 dias.

Na seguinte fase, VII, o ciclo foi reduzido para dois dias e a eficiência voltou a diminuir, mas não foi observada a presença de ácidos orgânicos no efluente. Na fase VIII, foi observada queda mais acentuada ainda de eficiência em cerca de $30 \%$, que foi atribuída à redução do tempo de ciclo de dois para um dia, na tentativa de otimizar o sistema. Além disso, ocorreu uma interrupção de energia elétrica durante um final de semana, aproximadamente no ciclo 70. Após este fato, houve decréscimo gradual da eficiência de remoção de DQO até $9 \%$ no ciclo 78 e aumento de ácidos orgânicos de $216 \mathrm{mg} / \mathrm{L}$ (ciclo 70) para $711 \mathrm{mg} / \mathrm{L}$ (ciclo 79).

Algumas hipóteses que poderiam justificar o mau desempenho do reator foram os procedimentos de coleta e armazenamento do inóculo termofílico.

Com relação à coleta, acredita-se que a separação dos microrganismos anaeróbios do meio suporte não deveria ter sido feita, pois conforme os resultados 
microbiológicos apresentados no item 5.3.4 o reator que tratava vinhaça de cana-deaçúcar em condição termofílica era abundantemente colonizado por arquéias com morfologia semelhante à Methanosarcina que, segundo van Lier (1996), são microrganismos de fácil desprendimento e difícil formação de aglomerados com firme aderência ao meio suporte, que, neste caso, eram cubos de espuma de poliuretano. Ademais, essas arquéias têm alta sensibilidade a variações de temperatura. Portanto, a retirada do inóculo de um reator que operava a $55{ }^{\circ} \mathrm{C}$ e depois do transporte, o armazenamento a aproximadamente $4{ }^{\circ} \mathrm{C}$ por 41 dias pode ter afetado definitivamente a atividade metanogênica do lodo.

Wu et al. (1995) avaliaram o efeito da estocagem de grânulos anaeróbios metanogênicos mesofílicos a $4{ }^{\circ} \mathrm{C}$ e $22{ }^{\circ} \mathrm{C}$ por 18 meses. Os dados revelaram que a taxa de degradação de ácidos orgânicos diminuiu gradativamente a $22{ }^{\circ} \mathrm{C}$. Houve drástica redução da degradação de propionato e acetato a $4{ }^{\circ} \mathrm{C}$. Os autores recomendaram que, para um período relativamente curto (até 5 meses), os grânulos podem ser armazenados à temperatura ambiente (aproximadamente $20-22{ }^{\circ} \mathrm{C}$ ) com pequena perda da taxa de degradação de ácidos graxos voláteis (AGV). Observaram que os grânulos recuperaram completamente a atividade de degradação de AGV original em três dias quando armazenados por 31 dias a $22{ }^{\circ} \mathrm{C}$. Os grânulos armazenados a $22{ }^{\circ} \mathrm{C}$ durante 9 meses ainda apresentaram viabilidade de uso como inóculo de um reator, em que a taxa de degradação de AGV original foi recuperada depois de 15 a 20 dias de operação a $35{ }^{\circ} \mathrm{C}$. Porém, para períodos maiores, os estudos indicaram que é preferível manter os grânulos a $4^{\circ} \mathrm{C}$ ao invés de temperatura ambiente.

A temperatura pode exercer um efeito negativo na viabilidade de biomassa anaeróbia que não esteja estruturada na forma de grânulos, estando dispersa. Esse efeito pode ocorrer com maior intensidade na taxa de degradação que, dependendo do grau de especificidade do lodo quanto à diversidade de metanogênicas, pode ser irreversível.

Diante dos resultados de monitoramento do reator ASBBR tratando substrato semelhante à vinhaça de beterraba em que a biomassa foi imobilizada em cubos de espuma de poliuretano e dos argumentos expostos, outro experimento foi montado com lodo granular em condições mesofílicas e termofílicas para efeitos de comparação quanto à viabilidade de tratamento dessa água residuária com o inóculo original utilizado em todo experimento. Os grânulos íntegros foram usados por apresentarem maior diversidade de microrganismos e melhor arranjo já que a estrutura não foi 
alterada durante a coleta e o transporte até a Universidad de Valladolid. A atividade anaeróbia desses ensaios também foi avaliada.

\subsubsection{Ensaios com biomassa granulada suspensa em frascos-reatores sob condições mesofílicas e termofílicas}

Os dados das fases experimentais nos frascos-reatores anaeróbios em regime batelada com biomassa granulada suspensa em condições mesofílicas e termofílicas estão apresentados na Tabela 5.14.

Tabela 5.14 - Valores médios de DQO e de eficiência de remoção em frascos-reatores com biomassa granular suspensa tratando substrato semelhante à vinhaça de beterraba.

\begin{tabular}{cccc|ccc}
\hline & \multicolumn{3}{c|}{ DQO - Termofílico } & \multicolumn{3}{c}{ DQO - Mesofílico } \\
\cline { 2 - 7 } Fases & $\begin{array}{c}\text { Afluente } \\
\mathbf{\mathbf { D P }}(\mathbf{g} / \mathbf{L})\end{array}$ & $\begin{array}{c}\text { Efluente } \\
\mathbf{\pm} \mathbf{D P}(\mathbf{g} / \mathbf{L})\end{array}$ & $\begin{array}{c}\text { Eficiência } \\
(\boldsymbol{\%})\end{array}$ & $\begin{array}{c}\text { Afluente } \\
\mathbf{\mathbf { D P }} \mathbf{( g / L )}\end{array}$ & $\begin{array}{c}\text { Efluente } \\
\mathbf{\pm} \mathbf{D P}(\mathbf{g} / \mathbf{L})\end{array}$ & $\begin{array}{c}\text { Eficiência } \\
(\boldsymbol{\%})\end{array}$ \\
\hline I & 2,0 & n.a. & - & 2,0 & n.a. & - \\
II & $3,0 \pm 0,6$ & $2,8 \pm 0,5$ & 11 & $3,0 \pm 0,6$ & $0,7 \pm 0,2$ & 76 \\
III & $1,9 \pm 0,0$ & $2,7 \pm 0,0$ & 0 & $1,9 \pm 0,0$ & $0,2 \pm 0,0$ & 89 \\
IV & $2,1 \pm 1,4$ & $1,8 \pm 1,5$ & 29 & $5,7 \pm 4,8$ & $2,0 \pm 0,0$ & 60 \\
V & $1,0 \pm 0,0$ & $0,9 \pm 0,0$ & 9 & $2,5 \pm 0,1$ & $0,9 \pm 0,7$ & 62 \\
VI & $1,4 \pm 1,4$ & $1,1 \pm 0,1$ & 25 & $2,3 \pm 0,0$ & $0,5 \pm 0,0$ & 79 \\
VII & $1,4 \pm 0,4$ & $1,3 \pm 0,4$ & 10 & $1,8 \pm 0,0$ & $1,1 \pm 0,0$ & 40 \\
VIII & - & - & - & $6,4 \pm 2,0$ & $4,7 \pm 0,2$ & 35 \\
\hline
\end{tabular}

* DP - desvio padrão.

Nas Figuras 5.43 e 5.44 estão apresentados valores de eficiência de remoção de DQO em condições termofílicas e mesofílicas, respectivamente. 


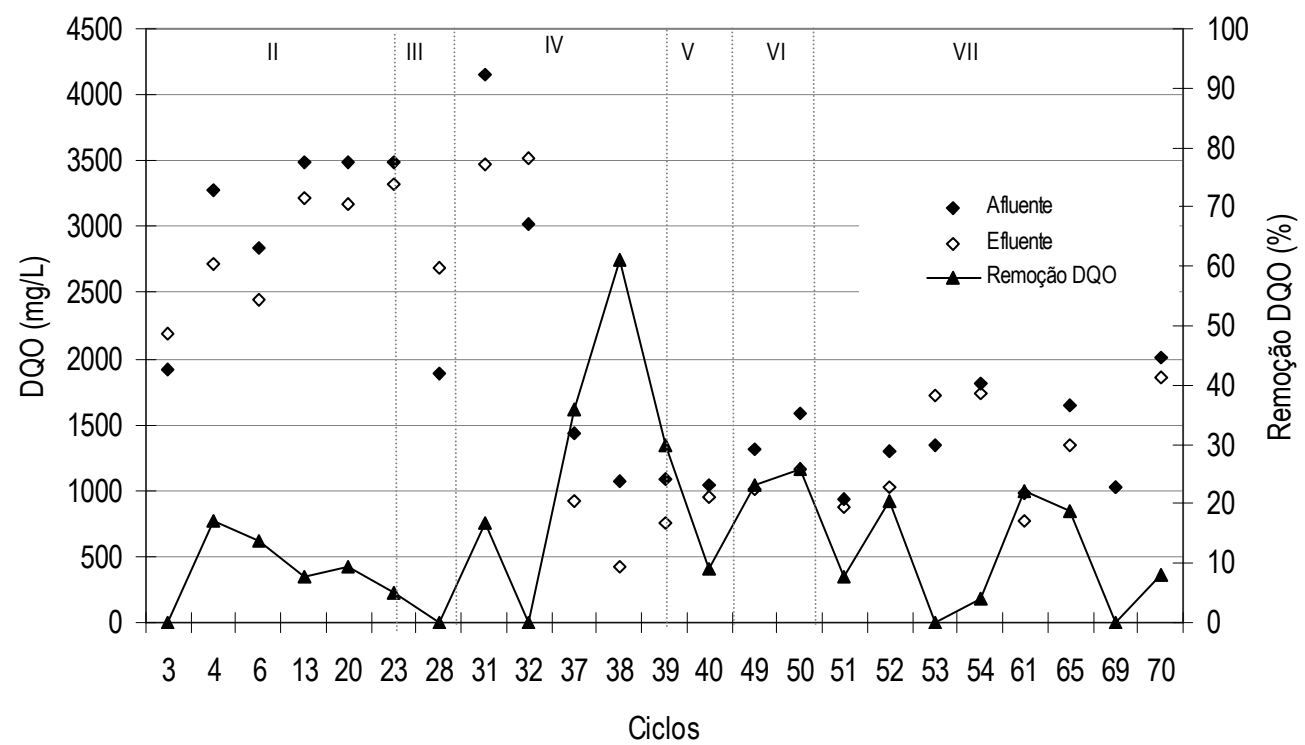

Figura 5.43 - Resultados do monitoramento da DQO afluente e efluente e da eficiência de remoção do frasco-reator termofílico com biomassa suspensa granulada tratando substrato semelhante à vinhaça do processamento da beterraba.

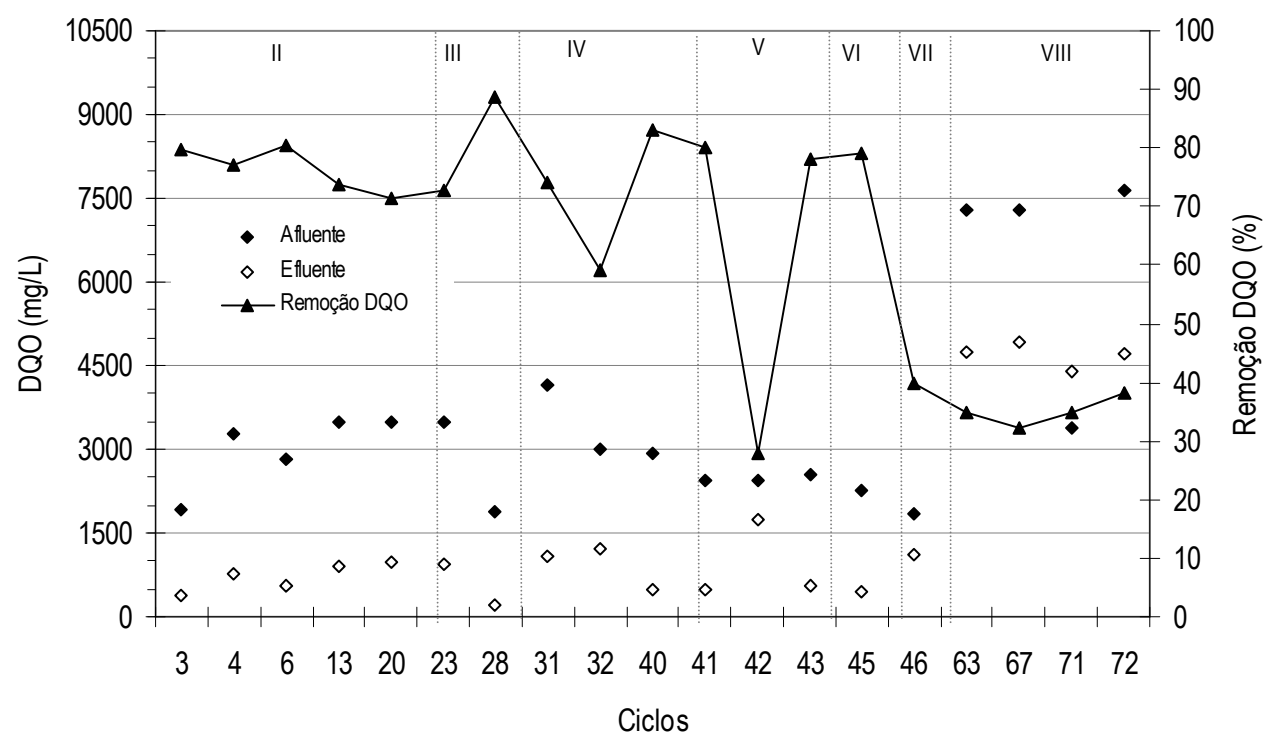

Figura 5.44 - Resultados do monitoramento da DQO afluente e efluente e da eficiência de remoção do frasco-reator mesofílico com biomassa suspensa granulada tratando substrato semelhante à vinhaça do processamento da beterraba.

$\mathrm{Na}$ primeira fase, os reatores foram alimentados com 2,0 gDQO/L por três ciclos de um dia e os efluentes não foram analisados.

No reator termofílico, observou-se baixa eficiência na remoção de DQO na fase II de em média de $11 \%$ (Tabela 5.14) que durou do $4^{\circ}$ ao $23^{\circ}$ ciclo. Nessa fase o tempo 
de ciclo foi aumentado de 1 para 2 dias a fim de promover maior tempo para a degradação de ácidos orgânicos que estavam em torno de 1300 a 1500 mg/L. Na fase III, foi verificada eficiência nula e AGV efluente de $1145 \mathrm{mg} / \mathrm{L}$, sendo que a DQO de entrada foi diminuída para $1,9 \mathrm{~g} / \mathrm{L}$ com tempo de ciclo mantido em 2 dias.

$\mathrm{Na}$ quarta fase, os ácidos orgânicos diminuíram gradativamente de $1515 \mathrm{mg} / \mathrm{L}$ (ciclo 32) para $218 \mathrm{mg} / \mathrm{L}$ (ciclo 40) com entrada de 2,1 gDQO/L. Mesmo assim, a eficiência de remoção de DQO média foi baixa de $29 \%$. Portanto, na fase seguinte (V), reduziu-se ainda mais a DQO de entrada para 1,0 g/L, aumentando-se o tempo de ciclo de acordo com a redução total de ácidos orgânicos, que ocorria em aproximadamente 7 dias.

Nas fases seguintes, a DQO de entrada foi aumentada para 1,4 g/L e tempo de ciclo diminuído para 3 dias na fase VI e, em seguida, para 2 e 1 dia na fase VII. A remoção média de DQO apresentou um aumento de $25 \%$ na fase VI voltando a diminuir para valores de $10 \%$ na fase VII. Deve-se observar, na Figura 5.43, que os valores reais obtidos foram acompanhados de instabilidade em todas fases experimentais.

Com relação ao reator com biomassa granulada mesofílica, pôde-se observar melhor desempenho comparado com o reator ASBBR e o frasco-reator com biomassa granulada ambos em condições termofílicas.

Nesse frasco-reator, o lodo granular apresentou excelente atividade logo após a inoculação, atingindo eficiências de remoção de DQO em cerca de $80 \%$ e $90 \%$ nas fases II e III com 3,0 e 1,9 g DQO/L, respectivamente.

$\mathrm{Na}$ fase IV, foi possível triplicar a DQO de entrada com eficiência média de $60 \%$, apesar de ter sido observado uma queda para $23 \%$ no ciclo 36 , o que pode ter ocorrido devido a um erro experimental, mas houve recuperação do desempenho após dois ciclos consecutivos mantendo-se nas fases seguintes.

A partir da fase $\mathrm{V}$, foi observada desestruturação do lodo granular, tanto em temperatura termofílica como mesofílica. Este fato se intensificou na fase VII, tendo ocorrido redução da eficiência de consumo dos ácidos orgânicos e aumento da DQO solúvel, devido à degradação da biomassa desprendida do lodo granular, que passou a apresentar aparência de lodo floculento.

Syutsubo et al. (2001) avaliaram a dinâmica populacional de consórcio microbiano anaeróbio de um lodo granular termofílico de reator UASB em reposta à mudança da composição do substrato de vinhaça de destilaria por 70 dias, depois para 
acetato por 111 dias e, finalmente, para sacarose por 192 dias. Observaram que durante o primeiro mês de cada fase, a atividade metanogênica e a densidade das células de metanogênicas quantificada pela técnica FISH (do inglês, fluorescence in situ hybridization) mudaram drasticamente como um resultado da troca da composição do substrato. Quando foi utilizado o acetato, o lodo granular retido foi parcialmente desintegrado devido à diminuição no número de microrganismos da comunidade simbiótica entre acetogênicas (acidogênicas) e metanogênicas hidrogenotróficas, que são efetivas na formação de grânulos termofílicos.

A biomassa do reator termofílico apresentava-se sedimentada junto ao fundo, provavelmente devido à paralisação da produção de biogás. A Figura 5.45 ilustra a decantação da biomassa granular dos frascos-reatores na fase $\mathrm{V}$, ciclo 42 .

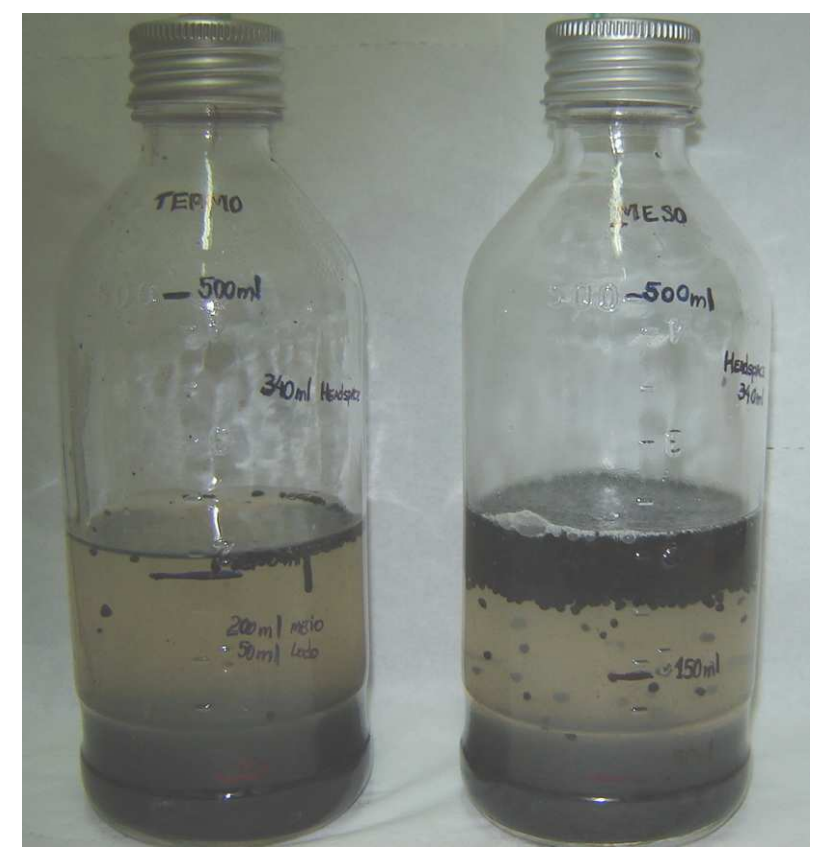

Figura 5.45 - Frascos-reatores com biomassa granular suspensa operado em condições termofílicas (frasco da esquerda) e mesofílicas (frasco da direita) no ciclo 42.

Nesse ensaio foi possível observar as consequiências de desestruturação destacadas por van Lier (1993) quando se utiliza um lodo granular mesofílico como inóculo de um reator termofílico: perda da forma de grânulo, aparecimento de uma matriz esponjosa e acidificação do líquido pela deterioração da biomassa inativa.

Considerando a porcentagem de metano e gás carbônico, pôde-se observar que biogás do frasco-reator termofílico apresentou alta porcentagem de $\mathrm{CO}_{2}$ nos ciclos iniciais, de 75 a $85 \%$, diminuindo para 40 e $50 \%$ nos ciclos finais e o conteúdo de 
metano variou entre 17 e $58 \%$. Já o biogás do reator mesofílico apresentou entre 20 e $30 \%$ de $\mathrm{CO}_{2}$ e de 67 e $79 \%$ de $\mathrm{CH}_{4}$, o que indicou maior estabilidade do processo metanogênico em condições mesofílicas que termofílicas. A relação entre o teor de $\mathrm{CH}_{4}$ e $\mathrm{CO}_{2}$ no biogás está apresentada na Figura 5.46.

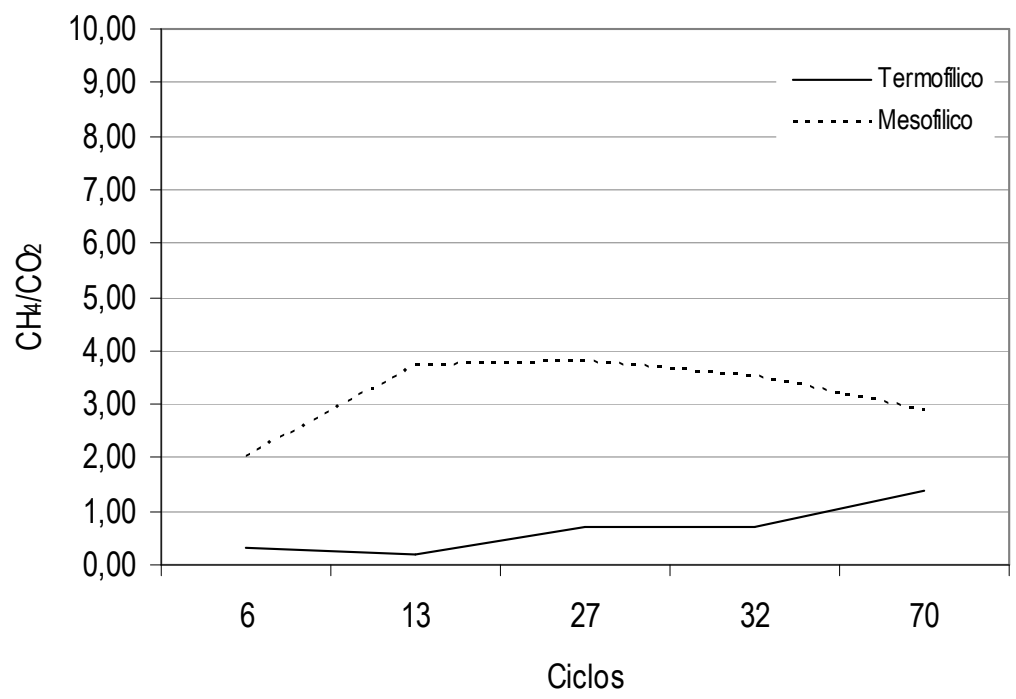

Figura 5.46 - Relação entre $\mathrm{CO}_{2}$ e $\mathrm{CH}_{4}$ do biogás do headspace dos reatores com biomassa granulada suspensa.

No final da fase VII do frasco-reator operado em condição termofílica, foi observado o acúmulo crescente de ácidos orgânicos, chegando a $2348 \mathrm{mg} / \mathrm{L}$ (no ciclo 70) e a $2371 \mathrm{mg} / \mathrm{L}$ no mesofílico, na fase VIII (ciclo 72).

O potencial de atividade anaeróbia metanogênica do lodo granular estocado a $4{ }^{\circ} \mathrm{C}$ foi analisado a $55^{\circ} \mathrm{C}$ e a $35^{\circ} \mathrm{C}$. O lodo foi alimentado com o substrato sintético semelhante à vinhaça de beterraba com a finalidade de avaliar a viabilidade do lodo nessas condições. As curvas de produção de metano a partir de medidas de pressão estão apresentadas na Figura 5.47. 


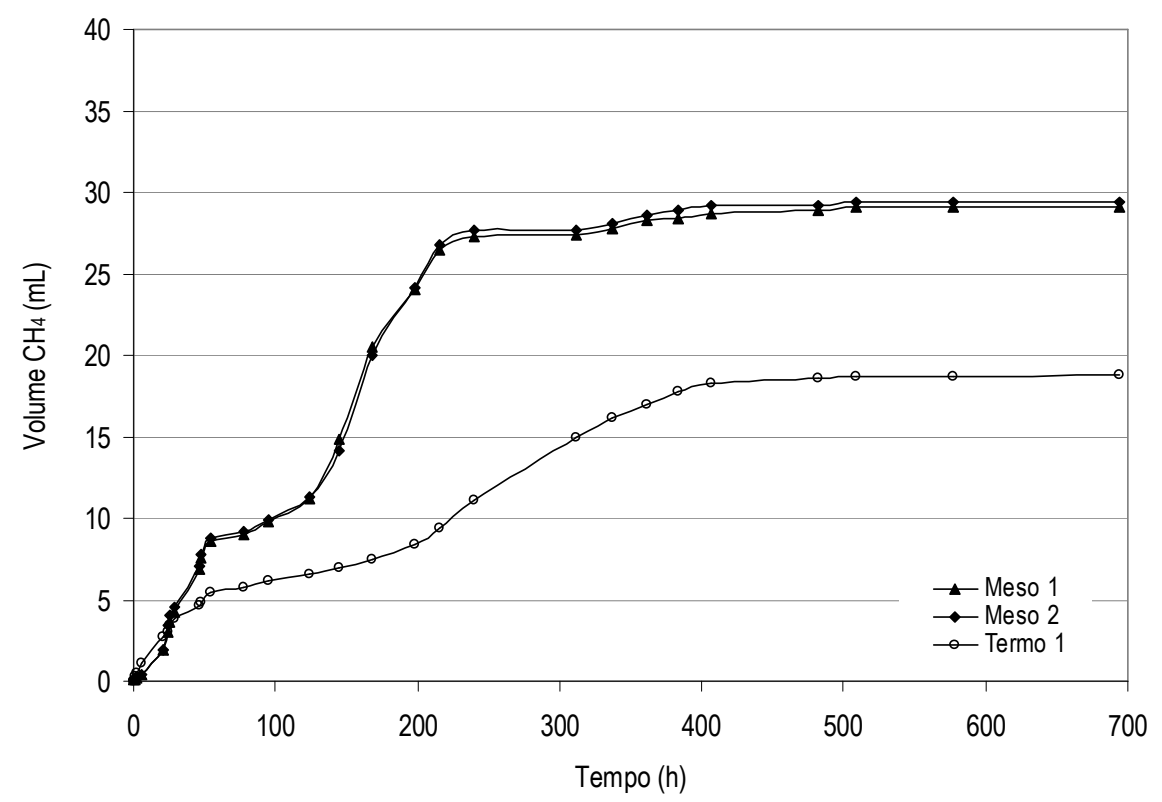

Figura 5.47 - Produção de metano por inóculo granulado mesofílico tratando substrato semelhante à vinhaça de beterraba em $35^{\circ} \mathrm{C}$ e $55^{\circ} \mathrm{C}$.

Ao final do experimento, pôde-se calcular que o potencial de biodegradação do resíduo pelo lodo de acordo com a relação DQO líquida no final do ensaio e DQO teórica foi de $65 \%$ em média em condições mesofílicas e de $41 \%$ em condição termofílica.

Com base nos bons resultados alcançados do potencial anaeróbio metanogênico no tratamento de vinhaça de beterraba sintética com lodo anaeróbio granular, partiu-se para o tratamento mesofílico em ASBBR de volume de 7,2 L para o tratamento de vinhaça de cana-de-açúcar a fim de comparar com a eficiência do mesmo reator em condições termofílicas anteriormente avaliada.

\subsection{Desempenho do reator anaeróbio mesofílico $\left(35^{\circ} \mathrm{C}\right)$ operado em batelada seqüencial contendo biomassa imobilizada com aumento gradativo de carga orgânica}

O reator ASBBR foi operado por 94 ciclos com tempo de ciclo fixo em um dia, submetido a seis cargas orgânicas de aproximadamente 2,5, 5,0, 7,5, 10,0, 20,0 e 30,0 gDQO/L.d que corresponderam à concentração afluente da vinhaça, expressa indiretamente como DQO. Os 21 ciclos iniciais foram destinados ao enriquecimento da biomassa com microrganismos metanogênicos. 


\subsubsection{Operação do reator na fase de enriquecimento}

A partida do reator foi realizada utilizando-se uma solução de etanol na concentração teórica de 1,0 gDQO/L, sais minerais e bicarbonato de sódio (relação 1:1 de $\mathrm{HCO}_{3}{ }^{-}$(DQO). Esse substrato foi adicionado no reator até o $8^{\circ}$ ciclo para estimular o desenvolvimento e colonização do meio suporte por arquéias metanogênicas.

Nos ciclos subseqüentes a DQO de entrada foi aumentada para 3,0 g/L (com $\mathrm{HCO}_{3}{ }^{-} / \mathrm{DQO}$ 0,33 no $9^{\circ}$ ciclo e diminuída para 0,17 , do ciclo 10 ao 14) e

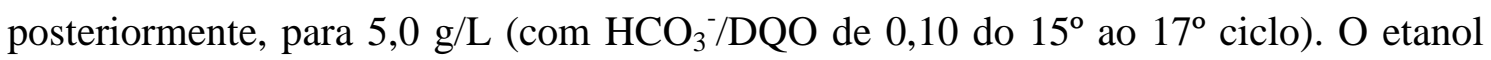
foi usado com o intuito de desenvolver maior população metanogênica capaz de degradá-lo no sistema.

Do $18^{\circ}$ ao $21^{\circ}$ ciclo o etanol foi substituído por vinhaça industrial e a carga orgânica aplicada foi diminuída para 2,5 gDQO/L.d e a relação $\mathrm{HCO}_{3}{ }^{-} / \mathrm{DQO}$ aumentada para 0,40 , que consistiram em medidas tomadas para evitar efeito negativo pela troca de substrato.

A Tabela 5.15 contém resultados de análises realizadas após 15 dias da partida do reator. No período anterior, não foram realizadas análises de monitoramento do sistema pelo desprendimento de biomassa não aderida nas espumas e pela instabilidade provocada pela partida e formação de um biofilme capaz de degradar a vinhaça.

Tabela 5.15 - Parâmetros físico-químicos monitorados no afluente e efluente na fase de enriquecimento do lodo do ASBBR mesofílico.

\begin{tabular}{lccc|ccc}
\hline \multicolumn{1}{c}{ Fase de enriquecimento do lodo - COV 3,40 gDQO/L.d } & \multicolumn{3}{c}{ Efluente } \\
\cline { 2 - 7 } \multicolumn{1}{c}{ Parâmetros } & Média \pm DP (nc)* & Mínimo & Máximo & Média \pm DP (nc) & Mínimo & Máximo \\
\hline DQO (g/L) & $3,41 \pm 0,28(5)$ & 3,10 & 3,62 & $1,58 \pm 0,86(4)$ & 0,96 & 2,80 \\
$\mathrm{AB}(\mathrm{mg} \mathrm{CaCO} / \mathrm{L})$ & $312,5 \pm 60,4(5)$ & 268,4 & 378,6 & $521,0 \pm 382(4)$ & 0,0 & 905,9 \\
$\mathrm{AVT}(\mathrm{mgHAc} / \mathrm{L})$ & $469,4 \pm 83,9(5)$ & 377,6 & 530,7 & $357,2 \pm 226(4)$ & 695,4 & 231,8 \\
$\mathrm{pH}$ & $6,7 \pm 0,15(5)$ & 6,6 & 6,9 & $7,0 \pm 1,1$ & 5,0 & 7,7 \\
$\mathrm{AI} / \mathrm{AP}$ & & & & $0,40 \pm 0,0$ & 0,40 & 0,40 \\
\hline
\end{tabular}

* DP - desvio padrão; nc - números de ciclos analisados. 


\subsubsection{Operação do reator na fase I com COV de 2,80 gDQO/L.d}

Nesta fase o reator operou com COV média de 2,80 gDQO/L.d e foi mantida a relação $\mathrm{HCO}_{3}{ }^{-} / \mathrm{DQO}$ de 0,40 do $22^{\circ}$ ao $25^{\circ}$ ciclos.

Os parâmetros monitorados durante esta fase se encontram na Tabela 5.16.

Tabela 5.16 - Parâmetros físico-químicos monitorados no afluente e efluente na fase I do ASBBR mesofílico.

\begin{tabular}{lccc|ccc}
\hline Fase I - COV 2,80 gDQO/L.d & \multicolumn{3}{c}{ Efluente } \\
\cline { 2 - 7 } \multicolumn{1}{c}{ Parâmetros } & \multicolumn{3}{c}{ Afluente } & \multicolumn{3}{c}{} \\
\cline { 2 - 7 } & Média \pm DP (nc)* & Mínimo & Máximo & Média \pm DP (nc) & Mínimo & Máximo \\
\hline $\mathrm{DQO}(\mathrm{g} / \mathrm{L})$ & $2,79 \pm 0,76(4)$ & 2,40 & 3,96 & $0,65 \pm 0,13(4)$ & 0,53 & 0,83 \\
$\mathrm{AB}(\mathrm{mg} \mathrm{CaCO} / \mathrm{L})$ & $589,0 \pm 16,3(4)$ & 564,6 & 597,2 & $1365 \pm 163(4)$ & 1254 & 1604 \\
$\mathrm{AVT}(\mathrm{mgHAc} / \mathrm{L})$ & $341,2 \pm 0,8(4)$ & 340,9 & 342,4 & $106,5 \pm 47(4)$ & 63 & 157 \\
$\mathrm{pH}$ & $6,9 \pm 0,05(4)$ & 6,8 & 6,9 & $7,5 \pm 0,2$ & 7,3 & 7,7 \\
$\mathrm{AI} / \mathrm{AP}$ & & & $0,40 \pm 0,0$ & 0,3 & 0,40 \\
\hline * DP - desvio padrão; $\mathrm{nc}$ - números de ciclos analisados.
\end{tabular}

* DP - desvio padrão; nc - números de ciclos analisados.

Observou-se que a os valores de $\mathrm{AB}$ efluente dobraram com relação à fase de adaptação e que os AVT diminuíram apesar de ser mantida $\mathrm{HCO}_{3}{ }^{-} / \mathrm{DQO}$. Mas, em média o reator foi submetido a uma COV menor (2,80 gDDO/L.d) que na fase de adaptação (3,40 gDQO/L.d).

No $25^{\circ}$ ciclo foram realizados perfis de remoção de DQO efluente, $\mathrm{pH}$, ácidos orgânicos e composição de biogás que estão apresentados nas Figuras 5.48, 5.49, 5.50 e 5.51 , respectivamente. Também foram quantificados os teores de fenol nas amostragens do perfil temporal.

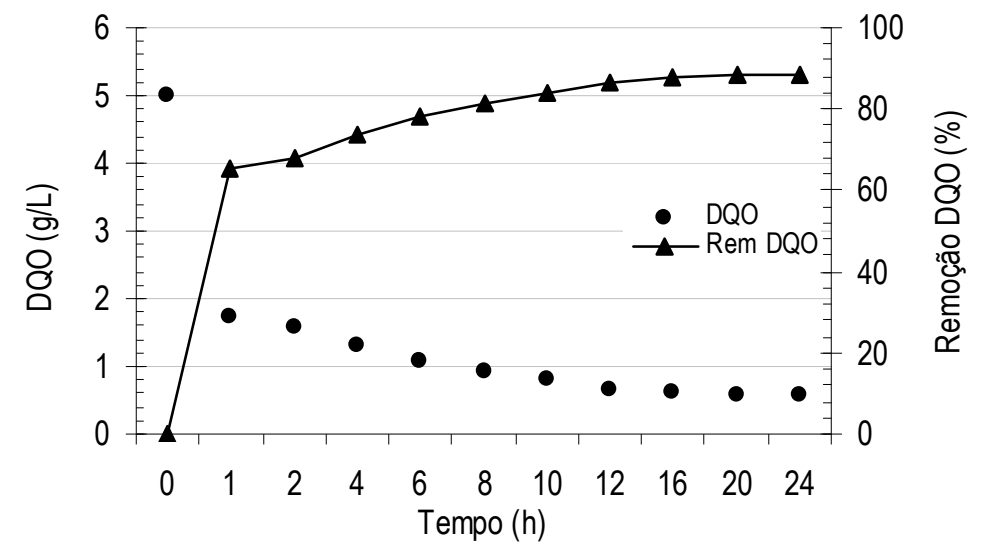

Figura 5.48 - Perfil de DQO ao longo do ciclo 25, fase I, em ASBBR mesofílico. 
Observa-se, na Figura 5.48, que o decaimento da DQO foi constante ao longo de todo ciclo atingindo ao final da batelada $88 \%$ de remoção, mas que na primeira hora do ciclo, $60 \%$ da DQO de entrada havia sido consumido.

Este fato demonstra que, a partir desse ponto de amostragem, o prolongamento do ciclo até 24 horas serviu como polimento do efluente, que é uma das características desta configuração de reator em que é feita a descarga do efluente quando sua qualidade já tiver alcançado concentrações desejadas (ZAIAT et al., 2001).

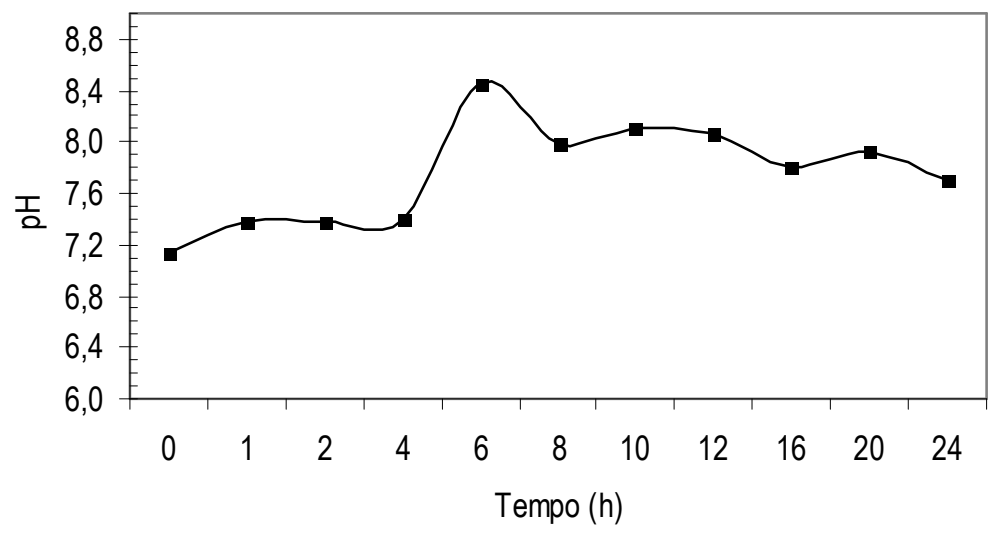

Figura 5.49 - Perfil de $\mathrm{pH}$ ao longo do ciclo 25, fase I, ASBBR mesofílico.

O reator mesofílico foi operado com valores de $\mathrm{pH}$ efluente além de 7,4 a partir da $6^{\mathrm{a}}$ hora da batelada quando atingiu 8,5. A partir da oitava hora o $\mathrm{pH}$ diminuiu constantemente até 7,7 no final da batelada (Figura 5.49).

A partir da oitava hora da batelada observou-se que os ácidos orgânicos determinados no efluente, especialmente ácidos acético e propiônico, que estavam presentes em maiores quantidades, foram consumidos à medida que eram produzidos dentro do reator (Figura 5.50). 


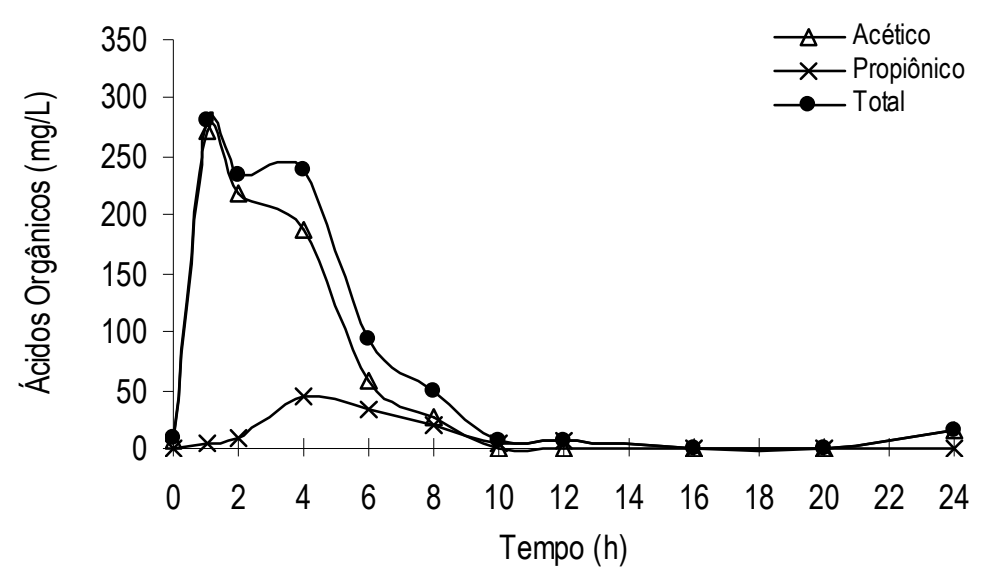

Figura 5.50 - Perfil de ácidos orgânicos ao longo do ciclo 25, fase I, ASBBR mesofílico.

Na Figura 5.51, está apresentada a relação dos gases metano e gás carbônico produzidos e determinados em cada ponto do perfil.

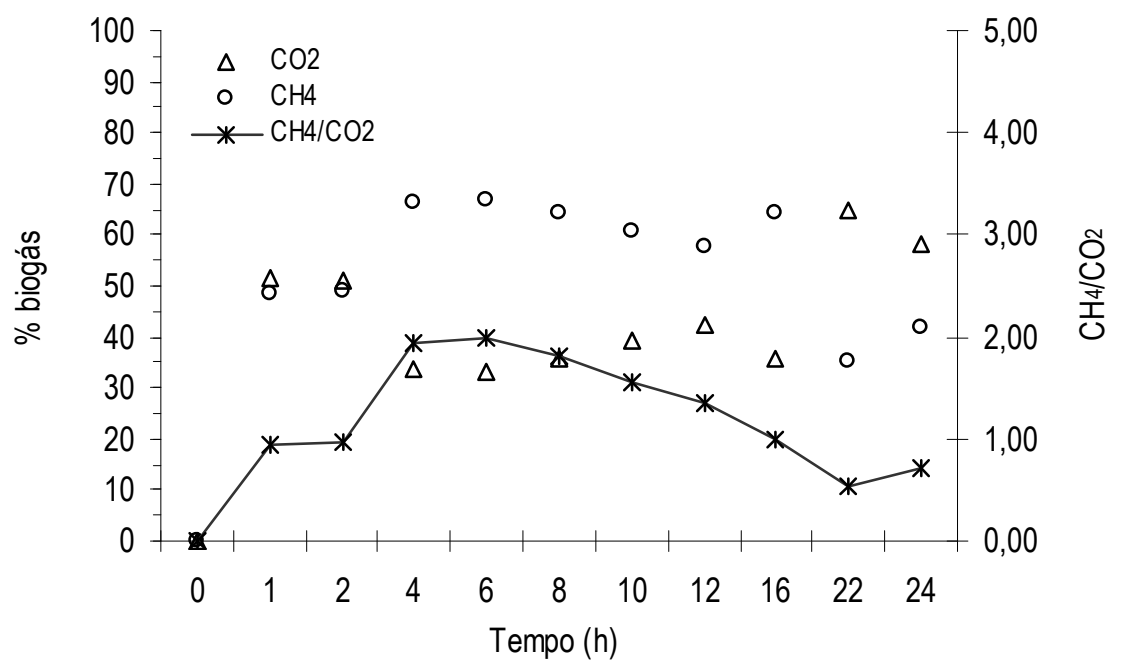

Figura 5.51 - Porcentagem e relação de $\mathrm{CH}_{4}$ e $\mathrm{CO}_{2}$ no biogás, fase I, ASBBR mesofílico.

A porcentagem dos gases, considerando a área cromatográfica obtida, mostra que a porcentagem de $\mathrm{CH}_{4}$ era maior que $60 \%$ de 4 a 16 horas com relação ao $\mathrm{CO}_{2} \mathrm{e}$ que, no final da batelada, diminuiu para 35 e $42 \%$ em 22 e 24 horas, respectivamente, como ilustrado pela Figura 5.51.

Foram detectados apenas traços de fenol o que significa que a concentração desta substância estava abaixo do limite de detecção que é cerca de $0,8 \mu \mathrm{g} / \mathrm{L}$. 
O período curto da fase I (do $22^{\circ}$ ao $25^{\circ}$ ciclos) foi devido ao bom patamar de eficiência de remoção de DQO média em $75 \%$. Com isso, o reator foi submetido a um aumento do carregamento orgânico.

\subsubsection{Operação do reator na fase II com COV de 6,40 gDQO/L.d}

O reator funcionou com COV média de 6,44 g DQO/L.d por 14 dias, do ciclo $26^{\circ}$ ao $42^{\circ}$.

Observou-se que a eficiência média de remoção de DQO e desvio padrão (DP) foi de 76,4\% $\%$ 9,6 \% correspondente a DQO efluente de 1,51 g/L \pm 0,54 g/L (Tabela 5.17). O valor do desvio padrão demonstrou que houve pouca oscilação durante toda a fase experimental, indícios de estabilidade do sistema.

Tabela 5.17 - Parâmetros físico-químicos monitorados no afluente e efluente na fase II do ASBBR mesofílico.

\begin{tabular}{cccc|ccc}
\hline Fase II - COV 6,40 gDQO/L.d & \multicolumn{3}{c}{ Efluente } \\
\hline \multirow{2}{*}{ Parâmetros } & \multicolumn{3}{c|}{ Afluente } & \multicolumn{3}{c}{} \\
\cline { 2 - 7 } & Média $\pm \mathrm{DP}(\mathrm{nc}) *$ & Mínimo & Máximo & Média $\pm \mathrm{DP}(\mathrm{nc})$ & Mínimo & Máximo \\
\hline $\mathrm{DQO}(\mathrm{g} / \mathrm{L})$ & $6,44 \pm 0,25(9)$ & 6,01 & 6,59 & $1,51 \pm 0,54(9)$ & 1,19 & 2,91 \\
$\mathrm{AB}(\mathrm{mg} \mathrm{CaCO} / \mathrm{L})$ & $980,0 \pm 135(8)$ & 763 & 1084 & $2085 \pm 526(9)$ & 999 & 2512 \\
$\mathrm{AVT}(\mathrm{mgHAc} / \mathrm{L})$ & $791,0 \pm 74,2(8)$ & 703 & 859 & $164 \pm 22(8)$ & 140 & 203 \\
$\mathrm{pH}$ & $6,7 \pm 0,05(8)$ & 6,7 & 6,8 & $7,8 \pm 0,2$ & 7,6 & 8,0 \\
$\mathrm{AI} / \mathrm{AP}$ & & & & $0,30 \pm 0,1$ & 0,3 & 0,40 \\
\hline
\end{tabular}

* DP - desvio padrão; nc - números de ciclos analisados.

Observou-se que a $\mathrm{AB}$ efluente continuou aumentando com relação ao afluente e que os AVT seguiam sendo consumidos, embora se tenha observado ácidos voláteis totais residuais no efluente superiores a $140 \mathrm{mg} / \mathrm{L}$.

Os perfis de DQO, pH, ácidos orgânicos, composição do biogás e fenol foram feitos no ciclo 42 quando sistema se apresentava estabilidade operacional com eficiência de remoção de DQO em torno de 78 \%.

O mesmo comportamento de remoção de DQO foi observado com esta carga orgânica, em que, na primeira hora da batelada $54 \%$ foi degradada. Com meia hora já havia diminuído para $51 \%$ (Figura 5.52). 


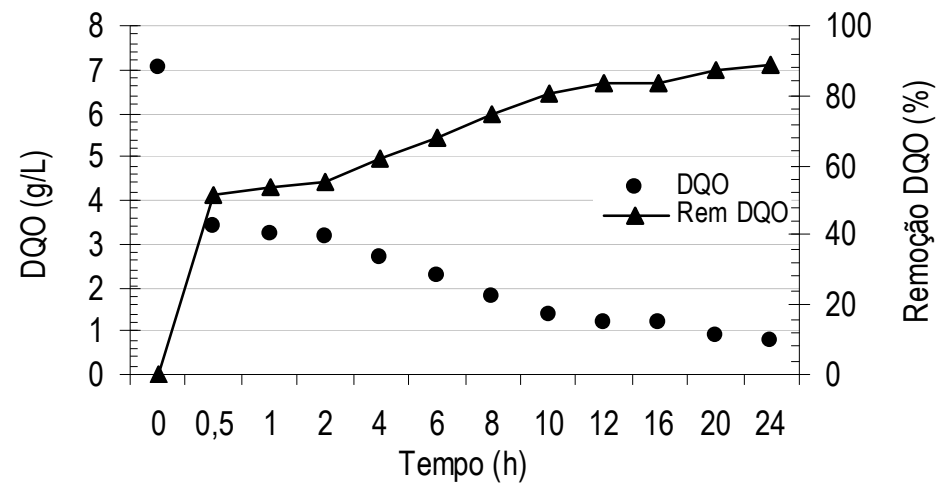

Figura 5.52 - Perfil de DQO ao longo do ciclo 42, fase II, em ASBBR mesofílico

O rápido consumo de matéria orgânica poderia ser atribuído ao efeito de diluição dentro do reator que ocasionaria a diferença entre o primeiro ponto ( 0 hora) e o segundo (0,5 hora), se todo líquido interno do reator não fosse esvaziado e enchido a cada nova batelada. Portanto, o resultado obtido pode ser atribuído à alta atividade dos microrganismos anaeróbios que formavam o biofilme no meio suporte.

$\mathrm{O}$ pH medido no efluente variou de 7,3 a 8,5, como pode ser visto na Figura 5.53. Nesta fase, a relação $\mathrm{HCO}_{3}{ }^{-} / \mathrm{DQO}$ calculada foi de 0,4 . Sendo assim, a adição de bicarbonato foi diminuída nas fases seguintes com a finalidade de diminuir os valores de $\mathrm{pH}$ efluente.

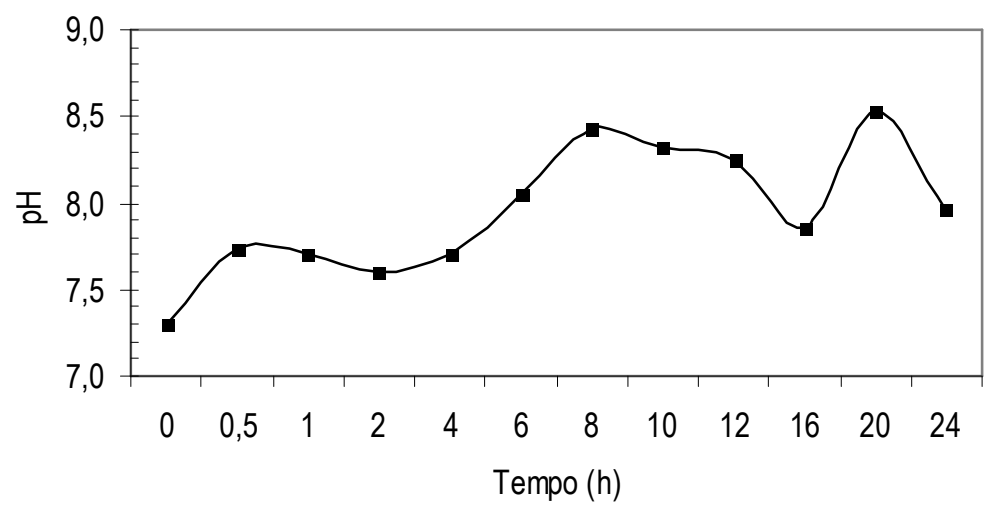

Figura 5.53 - Perfil de pH ao longo do ciclo 42, fase II, ASBBR mesofílico.

O acompanhamento do perfil de ácidos orgânicos revelou que a produção de ácidos indicava finalização somente após 20 horas do início da batelada. O ácido propiônico se acumulou no sistema chegando a $329 \mathrm{mg} / \mathrm{L}$ na $6^{\mathrm{a}}$ hora com lento consumo nas amostragens subseqüentes e, na última determinação, foi quantificado apenas 5,0 mg/L desse ácido. Na Figura 5.54 se encontram os perfis de ácido acético, 
propiônico e total (que engloba os outros ácidos com menor importância pela pouca quantidade determinada).

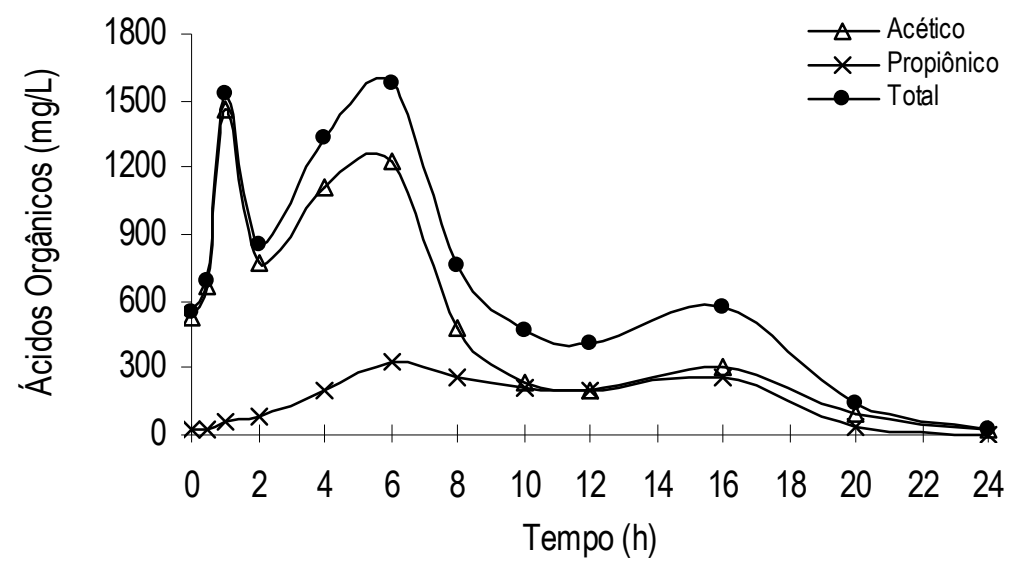

Figura 5.54 - Perfil de ácidos orgânicos, fase II, ASBBR mesofílico.

Por sua vez, a Figura 5.55 traz o perfil de composição de biogás e relação entre metano e gás carbônico.

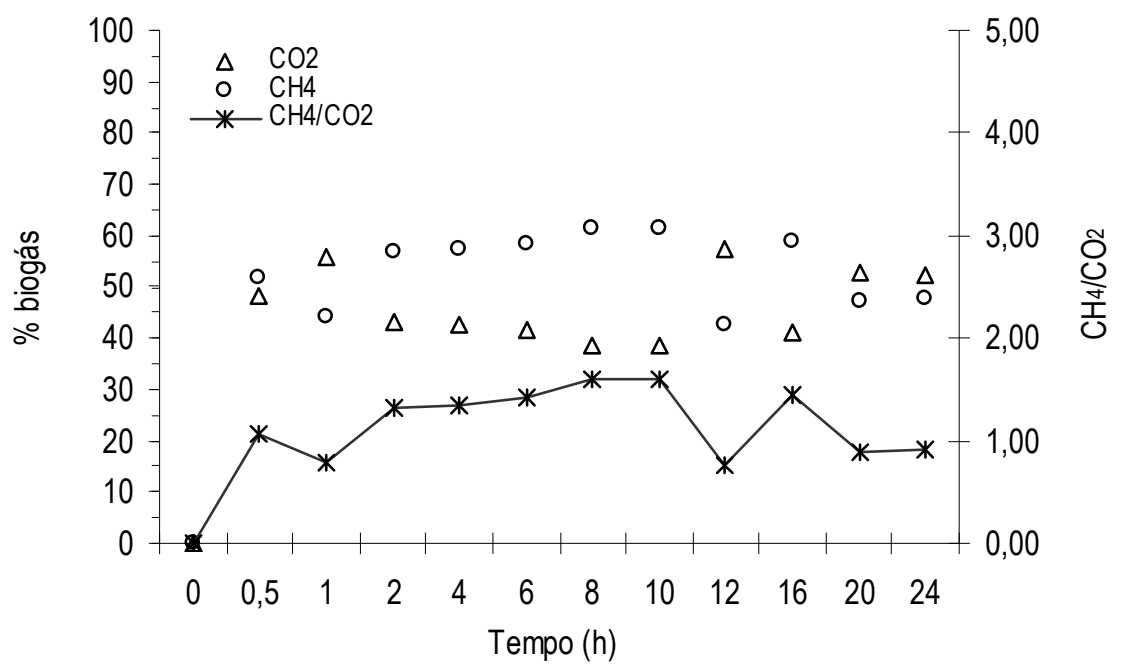

Figura 5.55 - Porcentagem e relação de $\mathrm{CH}_{4}$ e $\mathrm{CO}_{2}$ no biogás, fase II, ASBBR mesofílico.

De acordo com o perfil de metano pode-se observar que a porcentagem de metano diminuiu de $62 \%$ no ponto 10 horas para $47 \%$ em 20 e 24 horas, com menor relação $\mathrm{CH}_{4} / \mathrm{CO}_{2}$. 


\subsubsection{Operação do reator na fase III com COV de 7,90 gDQO/L.d}

A duração desta fase foi de aproximadamente 10 dias, do ciclo 43 ao 52, período em que foi aplicado uma COV de 7,90 g/L.d e mantido uma relação $\mathrm{HCO}_{3}{ }^{-} / \mathrm{CH}_{4}$ de 0,3 . A adição de bicarbonato no afluente foi diminuída (de 0,4 na fase anterior) com o objetivo de diminuir o pH efluente. Na Tabela 5.18 estão apresentados os parâmetros físico-químicos monitorados neste período.

Observou-se que mesmo após a diminuição de bicarbonato, o pH efluente excedia o limite ótimo da metanogênese que é considerado em 7,4, variando de 7,6 a 8,2 durante este período experimental.

Além dos valores de $\mathrm{pH}$ efluente altos, observou-se produção de alcalinidade a bicarbonato numa proporção de aproximadamente de três vezes a alcalinidade de entrada.

Com base nesses resultados, foi aplicada menor relação $(0,2)$ nas fases seguintes.

Tabela 5.18 - Parâmetros físico-químicos monitorados no afluente e efluente na fase III do ASBBR mesofílico.

\begin{tabular}{lccc|ccc}
\hline Fase III - COV 7,92 gDQO/L.d & \multicolumn{3}{c}{ Efluente } \\
\cline { 2 - 7 } \multicolumn{1}{c}{ Parâmetros } & \multicolumn{3}{c}{ Afluente } & \multicolumn{4}{c}{} \\
\cline { 2 - 7 } & Média \pm DP (nc)* & Mínimo & Máximo & Média \pm DP (nc) & Mínimo & Máximo \\
\hline DQO (g/L) & $7,92 \pm 1,04(7)$ & 6,52 & 8,74 & $1,72 \pm 0,43(7)$ & 1,24 & 2,59 \\
$\mathrm{AB}(\mathrm{mg} \mathrm{CaCO} / \mathrm{L})$ & $611,3 \pm 291(7)$ & 379 & 956 & $2543 \pm 175(7)$ & 2374 & 2788 \\
$\mathrm{AVT}(\mathrm{mgHAc} / \mathrm{L})$ & $1158 \pm 60(7)$ & 1026 & 1201 & $206 \pm 59(7)$ & 136 & 323 \\
$\mathrm{pH}$ & $6,8 \pm 0,20(8)$ & 6,7 & 7,0 & $8,0 \pm 0,21$ & 7,6 & 8,2 \\
$\mathrm{AI} / \mathrm{AP}$ & & & & $0,20 \pm 0,1$ & 0,1 & 0,30 \\
\hline
\end{tabular}

* DP - desvio padrão; nc - números de ciclos analisados.

A eficiência de remoção de DQO se manteve em um patamar considerado adequado entre 70 e $82 \%$. Assim, procedeu-se a aumento de COV e, portanto, mudança de condição operacional.

\subsubsection{Operação do reator na fase IV com COV de 10,60 gDQO/L.d}

O reator foi operado por 23 dias correspondentes ao $53^{\circ}$ ao $82^{\circ}$ ciclo com relação $\mathrm{HCO}_{3}{ }^{-} / \mathrm{CH}_{4}$ de 0,2 . 
O sistema continuou apresentando resultados de remoção de DQO de em média 78 \%. Inicialmente, logo após o aumento de carga orgânica, observou-se uma queda na eficiência de $82 \%$ para $68 \%$ nos primeiros 5 ciclos. A maior eficiência nesta fase foi atingida no $74^{\circ}$ ciclo com $87 \%$.

A Tabela 5.19 contém uma síntese dos resultados obtidos das análises realizadas na fase IV.

Tabela 5.19 - Parâmetros físico-químicos monitorados no afluente e efluente na fase IV do ASBBR mesofílico.

\begin{tabular}{lccc|ccc}
\hline Fase IV - COV 10,56 gDQO/L.d & \multicolumn{3}{c}{ Efluente } \\
\cline { 2 - 7 } \multicolumn{1}{c}{ Parâmetros } & \multicolumn{3}{c|}{ Afluente } & \multicolumn{3}{c}{} \\
\cline { 2 - 7 } & Média \pm DP (nc)* & Mínimo & Máximo & Média \pm DP (nc) & Mínimo & Máximo \\
\hline $\mathrm{DQO}(\mathrm{g} / \mathrm{L})$ & $10,56 \pm 2,80(7)$ & 7,55 & 14,50 & $2,21 \pm 0,40(7)$ & 1,75 & 2,94 \\
$\mathrm{AB}(\mathrm{mg} \mathrm{CaCO} / \mathrm{L})$ & $1551 \pm 1222(7)$ & 203 & 3848 & $4557 \pm 2155(7)$ & 2759 & 7751 \\
$\mathrm{AVT}(\mathrm{mgHAc} / \mathrm{L})$ & $1508 \pm 410(7)$ & 1083 & 2220 & $244 \pm 56(7)$ & 185 & 349 \\
$\mathrm{pH}$ & $6,6 \pm 0,40(7)$ & 6,1 & 7,0 & $7,9 \pm 0,10$ & 7,7 & 8,0 \\
$\mathrm{AI} / \mathrm{AP}$ & & & & $0,30 \pm 0,1$ & 0,3 & 0,40 \\
\hline
\end{tabular}

* DP - desvio padrão; nc - números de ciclos analisados.

O sistema seguia apresentando produção de alcalinidade a bicarbonato determinada no efluente com relação AI/AP em torno de 0,3 , indicando que o processo anaeróbio gerador de alcalinidade pela liberação do íon bicarbonato no meio estava ocorrendo mesmo com a alta carga orgânica.

Observou-se um pequeno aumento da quantidade de ácidos voláteis no efluente, apresentando concentração média de $244 \mathrm{mg} / \mathrm{L}$, mas não havia sido constatada nenhuma instabilidade do processo.

A fim de se avaliar o sistema e possibilidade de aumento de carga orgânica foram realizados dois perfis, um no ciclo 75 e outro, como réplica, no ciclo 81.

Como pode ser observado na Figura 5.56, praticamente a metade da DQO inicial foi removida em 0,5 e 1,0 hora, apesar do valor de DQO do ciclo 81 ter sido maior que do ciclo 75 .

O mesmo comportamento foi observado nos perfis das fases anteriores, indicando provavelmente que a biomassa apresentava grande capacidade de degradação dos compostos orgânicos presentes na vinhaça. 

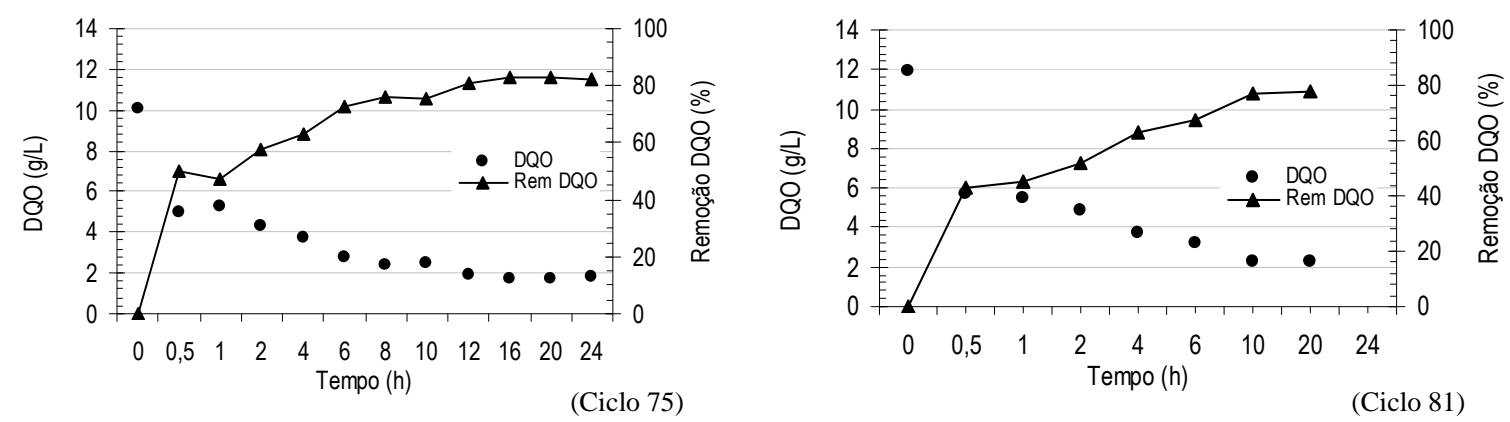

Figura 5.56 - Perfis de DQO ao longo dos ciclos 75 e 81, fase IV, em ASBBR mesofílico.

A maior remoção obtida no ciclo 75 foi em 12 horas com $81 \%$, permanecendo neste patamar até 24 horas com $83 \%$. E, no ciclo 81 a maior eficiência foi observada na amostragem realizada em 20 horas da batelada. Entre 10 e 20 horas não foram realizadas amostragens para análise, o que impossibilita precisar o ponto em que o reator atingiu a eficiência citada.

$\mathrm{O}$ pH medido nas amostragens do ciclo 75 variou de 6,9 (entrada) a 8,2 (em 4 horas) $\pm 0,4$. Já o pH do ciclo 81 variou de 7,1 (entrada) a 7,7 (em 10 horas) $\pm 0,2$. A Figura 5.57 mostra os perfis de $\mathrm{pH}$ realizados nesses ciclos.
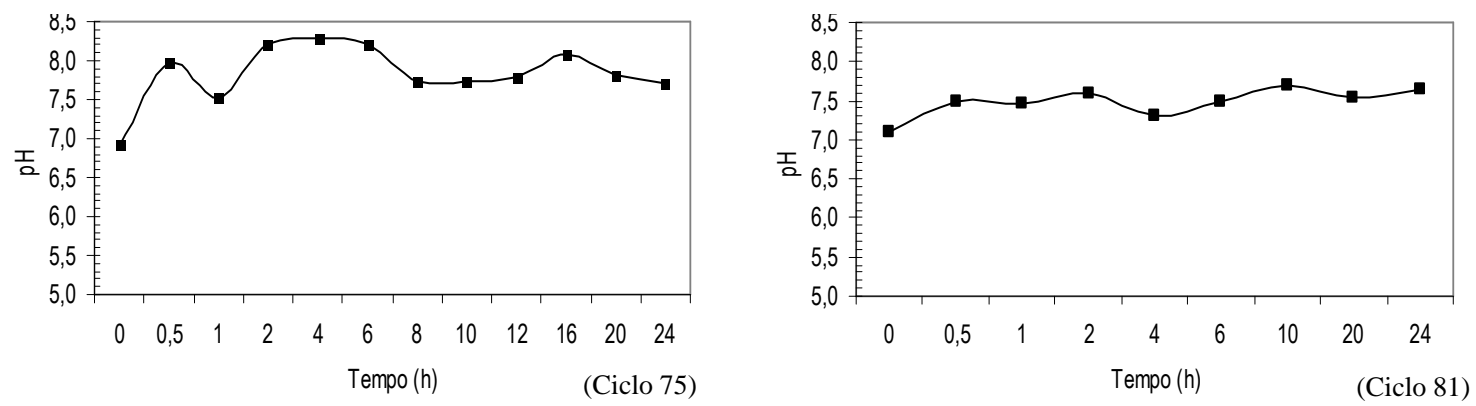

Figura 5.57 - Perfil de $\mathrm{pH}$ ao longo dos ciclos 75 e 81, fase IV, ASBBR mesofílico

Os gráficos da Figura 5.58 apresentam os perfis temporais de ácidos orgânicos, acético e propiônico, por estarem em maior quantidade nas amostras. Os demais ácidos, como butírico, iso butírico, valérico e iso valérico foram determinados e somados ao acético e propiônico para construção da linha correspondente aos ácidos totais. 

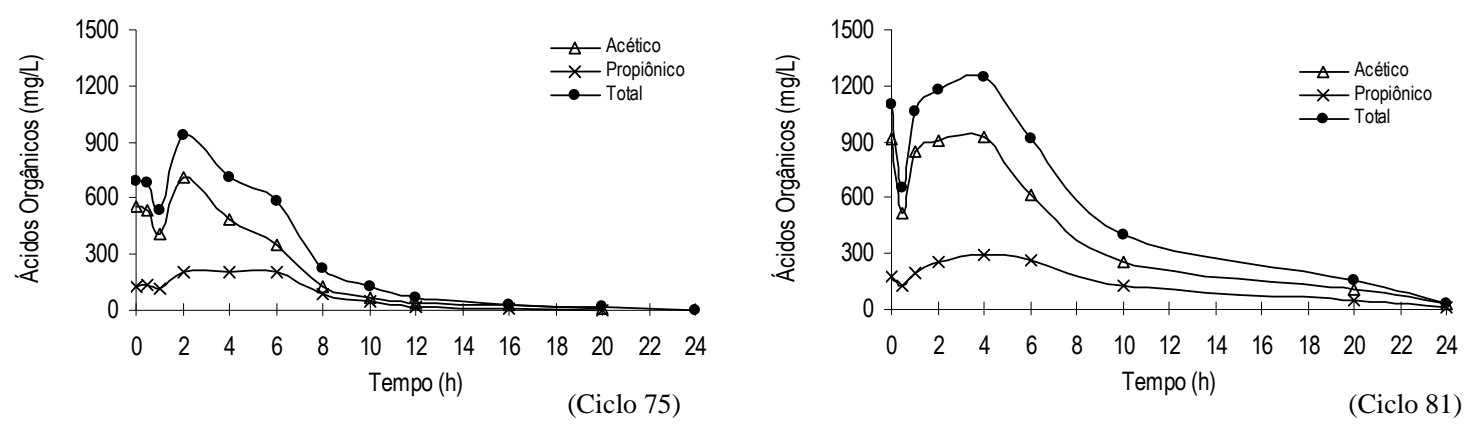

Figura 5.58 - Perfil de ácidos orgânicos ao longo dos ciclos 75 e 81, fase IV, ASBBR mesofílico.

No ciclo 75, observou-se um comportamento diferente da réplica feita posteriormente no ciclo 81, em que os ácidos que foram consumidos em 12 horas. $\mathrm{O}$ perfil realizado no ciclo 81 apresentou maior quantidade de ácidos orgânicos, que foram totalmente consumidos ao longo da batelada, consumo este comprovado na amostragem de 24 horas.

Os perfis temporais de DQO estão coerentes com os perfis de remoção de DQO, em que o maior consumo de ácidos correspondeu com o período de maior remoção de DQO.

No biogás, observou-se que houve predomínio do gás metano em relação ao $\mathrm{CO}_{2}$ em todas as amostragens realizadas nos perfis temporais desta fase, conforme gráficos da Figura 5.59. Nas últimas amostragens, não foi observada a queda acentuada de metano e o consequente predomínio de $\mathrm{CO}_{2}$, conforme comportamento observado nas fases anteriores.
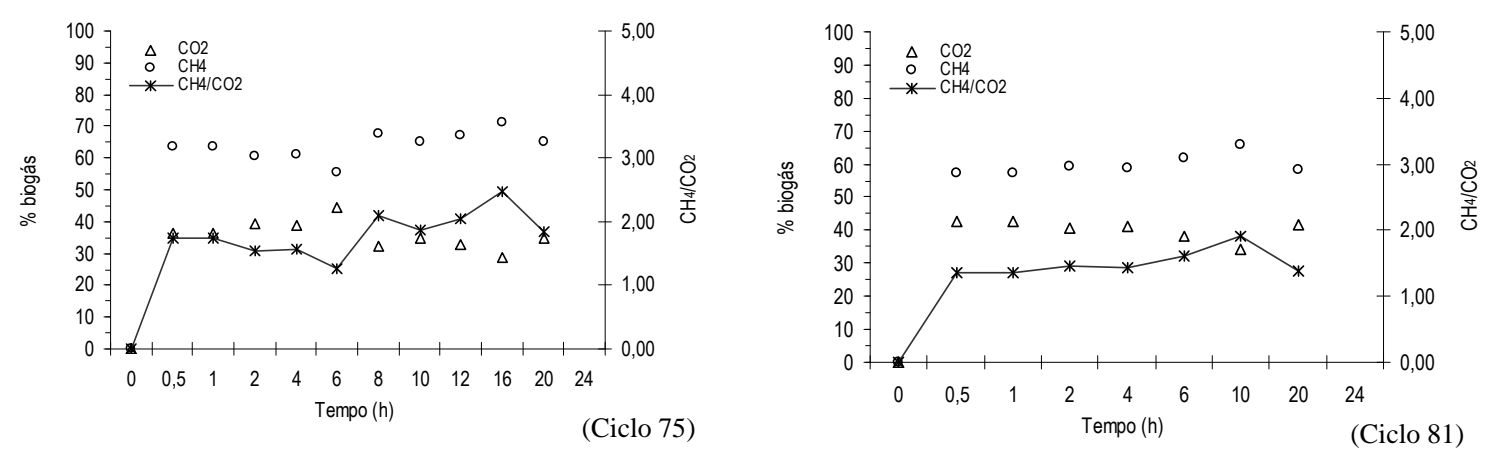

Figura 5.59 - Porcentagem e relação de $\mathrm{CH}_{4}$ e $\mathrm{CO}_{2}$ no biogás ao longo dos ciclos 75 e 81, fase IV, ASBBR mesofílico. 
Em todos os pontos amostrados ao longo dos dois perfis temporais foram detectados apenas traços de fenol em torno de $0,8 \mu \mathrm{g} / \mathrm{L}$.

Bolaños (2001) avaliou o tratamento de água residuária contendo fenol em RAHLF sob condições mesofílicas, em que obteve máxima eficiência de remoção de fenol de $99 \%$ para carga de fenol de 2,4 g/L.d, TDH de 12 horas e pH entre 7,5 e 8,5.

Portanto, as concentrações de fenol em que o ASBBR deste trabalho foi submetido por estar presente na vinhaça pode não ter provocado efeitos prejudiciais ao desempenho dos microrganismos anaeróbios.

Ainda sob essas condições operacionais do reator, foram retiradas amostras do meio suporte com biomassa para realizar testes de atividade metanogênica específica pela determinação da taxa de produção de gás metano pela população microbiana a partir de acetato de sódio na tentativa de levantar informações relativas à velocidade da metanogênese.

Logo no primeiro ponto de amostragem do teste que foi retirado após 2,72 horas, foi observada grande atividade metanogênica, o que dificultou a visualização do início da fase logarítmica tornando-se impossível calcular a velocidade específica (Figura 5.60). Isto ocorreu devido provavelmente a pouca quantidade de fonte de carbono adicionada aos frascos do ensaio que foi de $50 \mathrm{mM}$ de acetato de sódio, pois o lodo do reator nesta fase, estava adaptado a 10, $56 \mathrm{~g}$ de DQO/L em média.

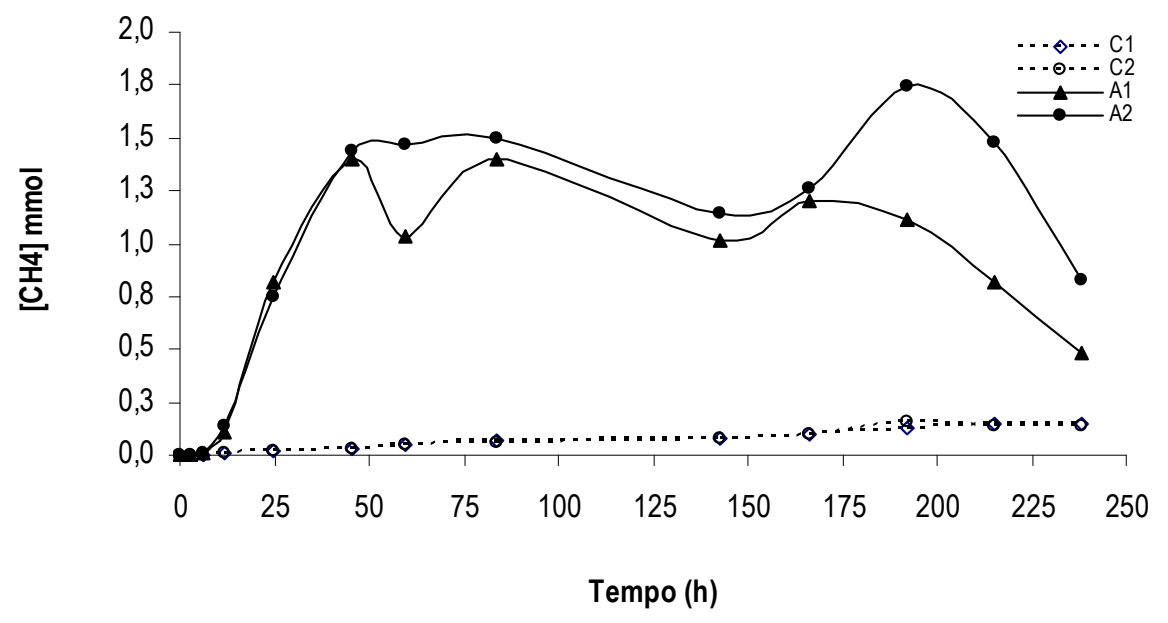

Figura 5.60 - Concentração de metano no biogás durante o tempo de incubação do teste de AME. 
Para se obter a velocidade máxima específica da população metanogênica, seria necessário realizar amostragens de biogás em menores intervalos de tempo com maior frequiência. Além disso, o tempo total de ensaio poderia ter sido de 50 horas, quando houve início da estabilização de produção de metano.

\subsubsection{Operação do reator na fase $\mathrm{V}$ com COV de 22,20 gDQO/L.d}

Com intuito de avaliar a estabilidade da biomassa anaeróbia formada no ASBBR, o reator foi submetido ao dobro de carga orgânica da fase anterior, cerca de 22 g/L.d no ciclo 83 se estendendo até o ciclo 89, com relação $\mathrm{HCO}_{3}{ }^{-} / \mathrm{DQO}$ de 0,2.

O reator não apresentou queda de eficiência na remoção de DQO. A média obtida de remoção para DQO centrifugada foi de $85 \pm 4 \%$ nas seis amostragens realizadas.

Os parâmetros monitorados durante esta fase experimental estão apresentados na Tabela 5.20.

Tabela 5.20 - Parâmetros físico-químicos monitorados no afluente e efluente na fase V do ASBBR mesofílico.

\begin{tabular}{lccc|ccc}
\hline Fase V - COV 22,23 gDQO/L.d & \multicolumn{3}{c}{ Efluente } \\
\cline { 2 - 7 } \multicolumn{1}{c}{ Parâmetros } & \multicolumn{3}{c}{ Afluente } & \multicolumn{3}{c}{} \\
\cline { 2 - 7 } & Média $\pm \mathrm{DP}(\mathrm{nc}) *$ & Mínimo & Máximo & Média $\pm \mathrm{DP}(\mathrm{nc})$ & Mínimo & Máximo \\
\hline $\mathrm{DQO}(\mathrm{g} / \mathrm{L})$ & $22,23 \pm 2,58(6)$ & 19,88 & 24,58 & $3,31 \pm 0,89(6)$ & 1,55 & 4,06 \\
$\mathrm{AB}(\mathrm{mg} \mathrm{CaCO} / \mathrm{L})$ & $4234 \pm 47(6)$ & 4190 & 4277 & $11728 \pm 1027(6)$ & 10197 & 12857 \\
$\mathrm{AVT}(\mathrm{mgHAc} / \mathrm{L})$ & $3459 \pm 439(6)$ & 3958 & 3860 & $360 \pm 156(6)$ & 233 & 654 \\
$\mathrm{pH}$ & $6,7 \pm 0,20(6)$ & 6,5 & 6,9 & $8,0 \pm 0,11$ & 7,8 & 8,1 \\
$\mathrm{AI} / \mathrm{AP}$ & & & & $0,3 \pm 0,0$ & 0,3 & 0,4 \\
\hline
\end{tabular}

* DP - desvio padrão; nc - números de ciclos analisados.

A relação AI/AP seguiam em 0,3 , produção de alcalinidade a bicarbonato, consumo de AVT e pH em torno de 8,0. Estes resultados indicam que o processo de digestão anaeróbia não havia sido comprometido mesmo com a alta carga aplicada.

Frente a tais resultados, o reator foi submetido a novo aumento de carga orgânica. 


\subsubsection{Operação do reator na fase VI com COV de 36,0 gDQO/L.d}

O reator foi alimentado com vinhaça concentrada com DQO de aproximadamente $36 \mathrm{~g} / \mathrm{L}$ por 4 ciclos consecutivos, do $90^{\circ}$ ao $94^{\circ}$. Foi um período relativamente curto para avaliação do desempenho do reator, mas útil no sentido de observar a estabilidade do sistema frente a carregamentos orgânicos repentinos.

Na Tabela 5.21 estão apresentados dados do monitoramento deste período.

Tabela 5.21 - Parâmetros físico-químicos monitorados no afluente e efluente na fase VI do ASBBR mesofílico.

\begin{tabular}{lccc|ccc}
\hline Fase VI - COV 35,94 gDQO/L.d & \multicolumn{3}{c}{ Efluente } \\
\cline { 2 - 7 } \multicolumn{1}{c}{ Parâmetros } & \multicolumn{3}{c}{ Afluente } & \multicolumn{4}{c}{ cia (nc)* } & Mínimo & Máximo & Média \pm DP (nc)* & Mínimo & Máximo \\
\hline DQO (g/L) & $35,94(3)$ & 35,90 & 35,94 & $7,56 \pm 0,77(3)$ & 6,75 & 8,27 \\
AB (mg CaCO3/L) & $6646,2(3)$ & 6646,2 & 6646,2 & $15090 \pm 1459(2)$ & 14058 & 16121 \\
AVT (mgHAc/L) & $4682,6(3)$ & 4682,6 & 4682,6 & $1194 \pm 149(2)$ & 1089 & 1300 \\
pH & $7,1(3)$ & 7,1 & 7,1 & 8,0 & 8,0 & 8,0 \\
AI/AP & & & & $0,4 \pm 0,0$ & 0,4 & 0,5 \\
\hline
\end{tabular}

* DP - desvio padrão; nc - números de ciclos analisados.

A eficiência foi monitorada nos ciclos 90, 91 e 92, seguintes ao aumento de carga. Nesses ciclos foram obtidas eficiências decrescentes de $81 \%, 79 \%$ e $77 \%$, respectivamente.

$\mathrm{O}$ pH medido foi de 8,0 nos ciclos 90 e 91. A AVT residual foi de $1089\left(90^{\circ}\right.$ ciclo) e $1300 \mathrm{mgHAc} / \mathrm{L}$ ( $91^{\circ}$ ciclo) e relação AI/AP de 0,4 .

\subsubsection{Avaliação da eficiência e estabilidade do reator mesofílico ao longo das fases experimentais}

A seguir, serão apresentados os resultados da eficiência e estabilidade do reator mesofílico ao longo das fases experimentais.

Na Figura 5.61 estão apresentados os valores de DQO e de remoção ao longo das fases experimentais. 


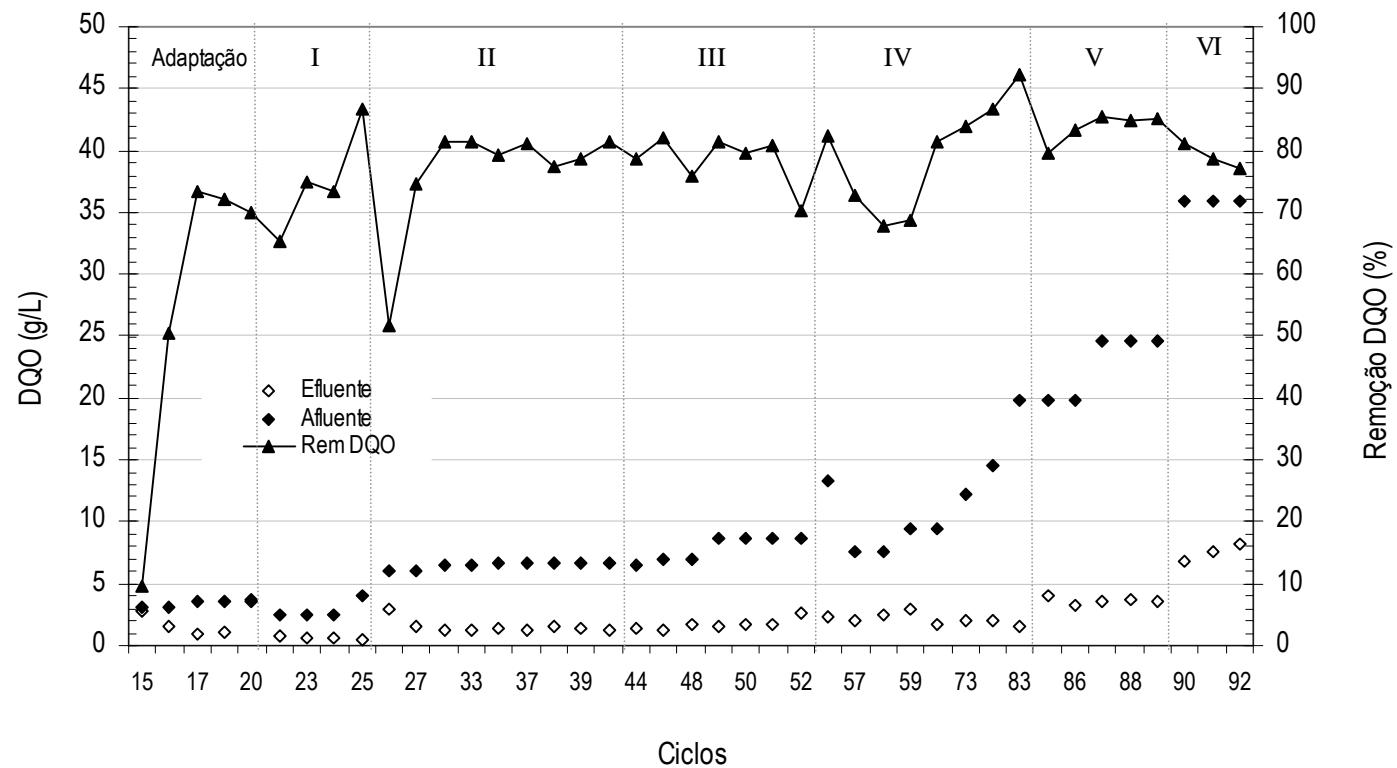

Figura 5.61 - Resultados do monitoramento da DQO afluente e efluente e eficiência de remoção de DQO no efluente durante todas as fases experimentais em condições mesofílicas.

Observa-se que o período adaptação do lodo foi curto, cerca de 20 dias, após o qual o reator já apresentava eficiência de remoção de DQO da ordem de 70\%, indicando que a biomassa não apresentou problemas de adaptação à vinhaça.

$\mathrm{Na}$ Figura 5.62, estão os valores de $\mathrm{pH}$ do afluente e efluente monitorados durante o experimento. Conforme mostra a figura, observa-se que o $\mathrm{pH}$ efluente não foi alterado pelo aumento da carga orgânica ao longo das fases experimentais em que se manteve na faixa de 7,5 a 8,2, o que indica estabilidade do processo anaeróbio do reator 


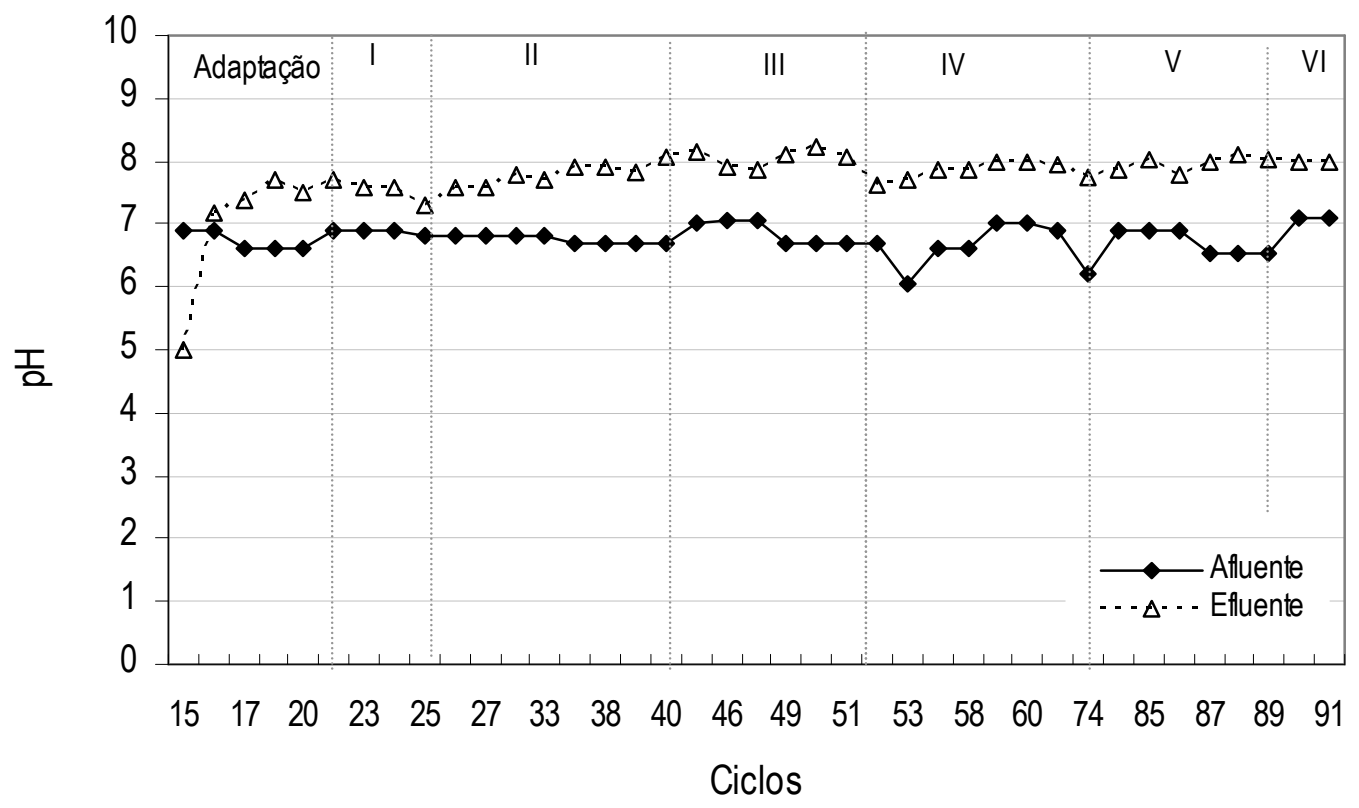

Figura 5.62 - Resultados do monitoramento do $\mathrm{pH}$ afluente e efluente durante todas as fases experimentais em condições termofílicas.

Observa-se que houve um aumento progressivo da alcalinidade a bicarbonato do efluente com o aumento da carga orgânica (Figura 5.63). Destaque-se que houve adição decrescente de bicarbonato de sódio na proporção $\mathrm{HCO}_{3}{ }^{-} / \mathrm{DQO}$ de 0,4 nas fases I e II, 0,3 na fase III e 0,2 na fase IV como precaução para manter o tamponamento do sistema.

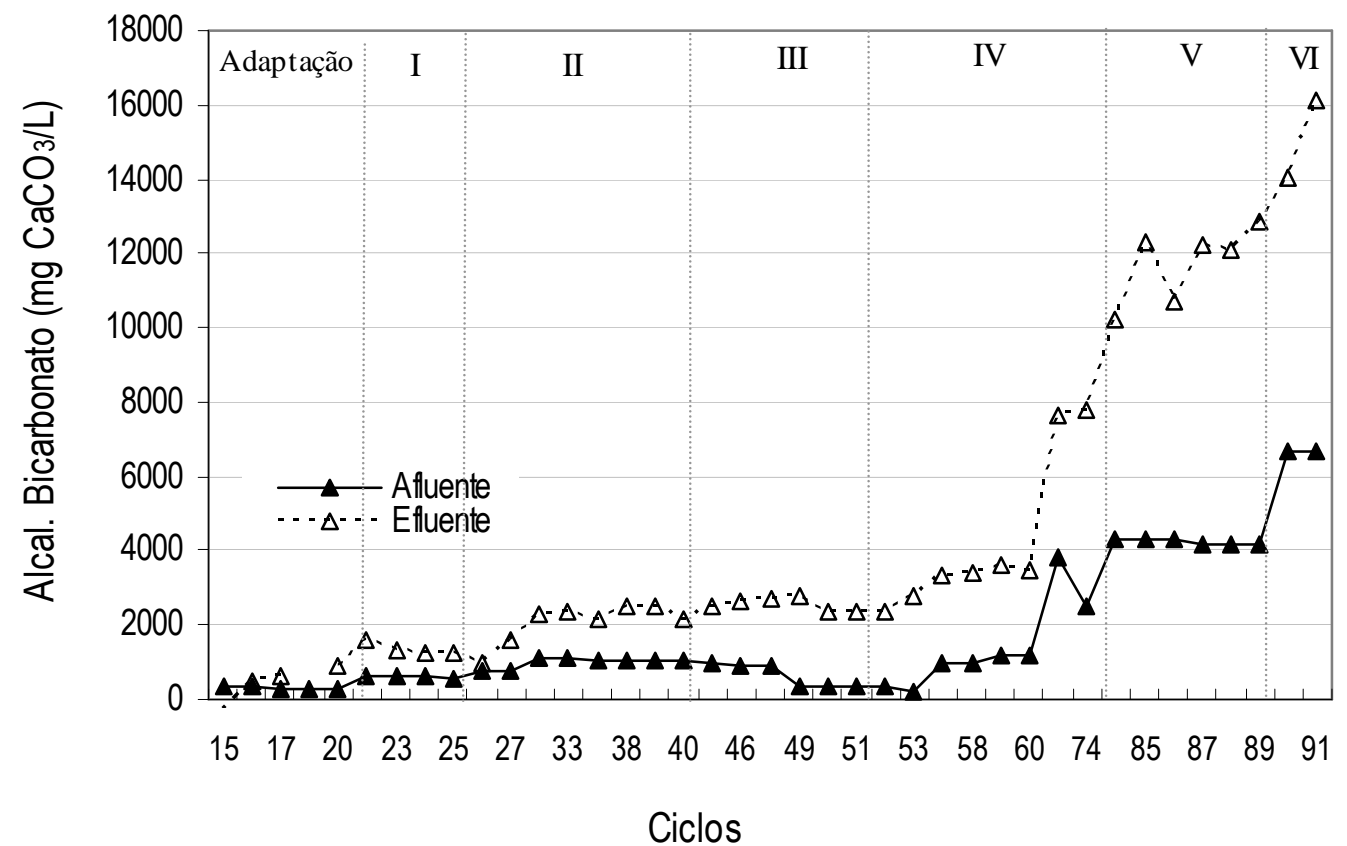

Figura 5.63 - Resultados do monitoramento da alcalinidade a bicarbonato durante todas as fases experimentais em condições termofílicas. 
A alcalinidade a bicarbonato determinada no efluente do reator nos ciclos analisados apresentou tendência crescente à medida que se aumentava a COV e os ácidos voláteis totais residuais no efluente ficaram abaixo de $200 \mathrm{mg} / \mathrm{L}$ até a fase IV (COV de 10,6 g/L.d). A partir da quinta fase a média de AVT efluente foi de $360 \mathrm{mg} / \mathrm{L}$ e na sexta de 1194,0 mg/L (Figura 5.64).

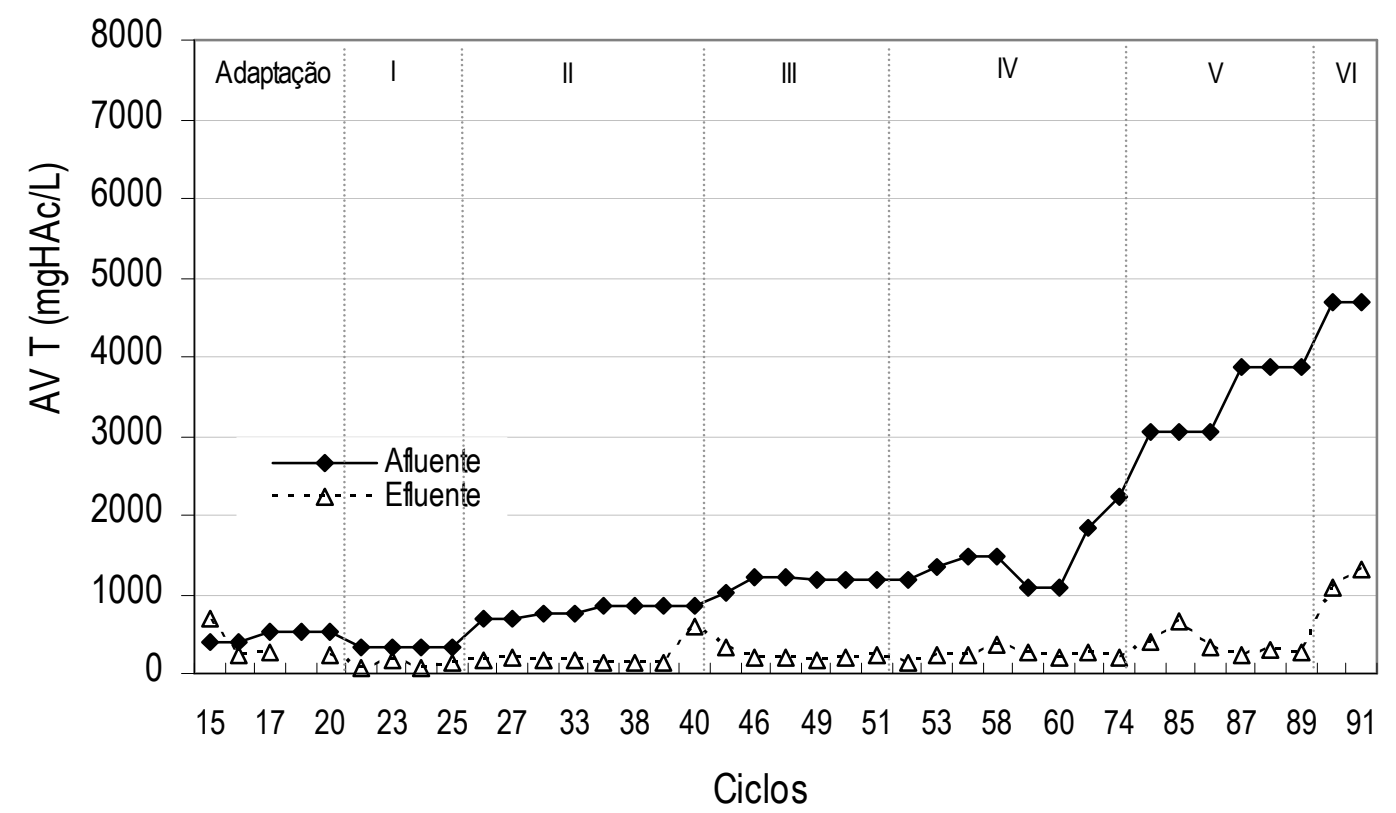

Figura 5.64 - Resultados do monitoramento da alcalinidade a bicarbonato durante todas as fases experimentais em condições termofílicas.

A relação AI/AP, que indica a proporção de alcalinidade devido ao bicarbonato e aos sais de ácidos voláteis, esteve próxima a 0,3, indicando certa estabilidade quanto a esses parâmetros conforme foi observado no caso particular do trabalho de Ripley et al. (1986) (Figura 5.65). 


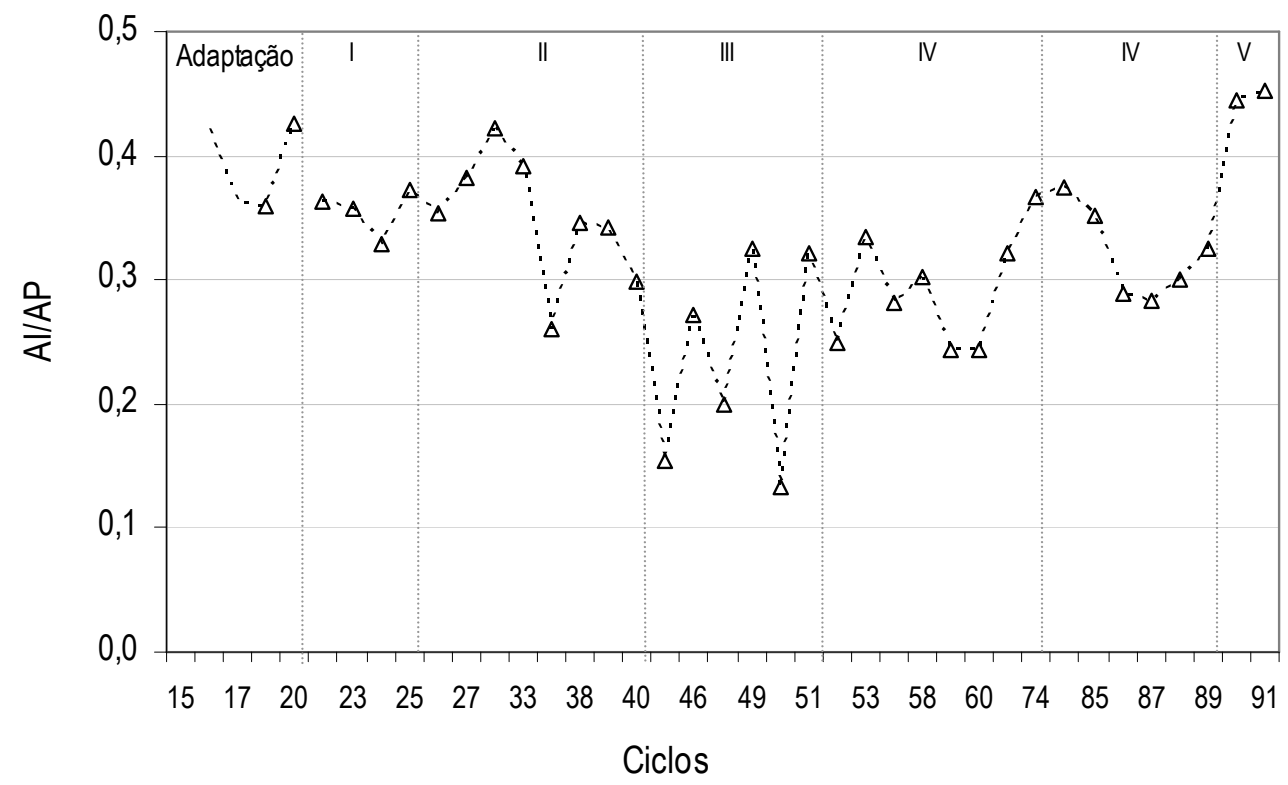

Figura 5.65 - Monitoramento da relação alcalinidade intermediária e parcial (AI/AP) durante todas as fases experimentais em condições termofílicas.

\subsubsection{Aspectos microbiológicos da biomassa imobilizada no reator mesofílico ao longo das fases experimentais}

Exames microscópios indicaram que o inóculo utilizado apresentou grande quantidade e variedade de cocos e bacilos, coco-bacilos, bem como grande quantidade de células semelhantes à Methanosaeta e Methanosarcina.

Após o período de adaptação da biomassa, em que o etanol foi utilizado nos 15 dias iniciais, observou-se que a diversidade microbiana havia diminuído. Mesmo assim, foram observadas formas semelhantes a bacilos, Methanosaeta e formas que se assemelhavam a cistos.

Ao final da fase I, em que o reator já vinha sendo alimentado com vinhaça contendo 2,5 gDQO/L, a diversidade microbiana se restabeleceu. Foram observadas muitas formas de bacilos ovalados, retos, afilados, abundância de células semelhantes à Methanosaeta, leveduras e cocos. E, especialmente no meio e parte inferior do reator, observou-se a presença pouco significativa de algumas células semelhantes à Methanosarcina e bacilos fluorescentes.

Já ao final da fase II, com 5,0 gDQO/L, além do mesmo quadro, foram observados filamentos septados e com inclusões que podem estar relacionados com 
bactérias acidogênicas. As arquéias Methanosaeta seguiam predominando entre as metanogênicas.

Com o aumento da carga orgânica nas fases seguintes, foi observado o predomínio de células semelhantes à Methanosaeta que formavam aglomerados semelhantes a uma impressão digital em grande quantidade. Na superfície e meio do reator, foram encontrados formas de bacilos cocóides, poucos bacilos curvos semelhantes a bactérias redutoras de sulfato e algumas leveduras, oriundas provavelmente do resíduo. Não foram observadas células semelhantes à Methanosarcina.

Diante das observações morfológicas, pôde-se supor que o reator era essencialmente metanogênico com predomínio de células semelhantes à metanogênicas do gênero Methanosaeta.

A Tabela 5.22 mostra a incidência e distribuição das morfologias observadas no reator mesofílico durante operação das fases de adaptação, fase I, II e IV.

Tabela 5.22 - Incidência de morfologias observadas durante as fases experimentais em ASBBR sob condições mesofílicas.

\begin{tabular}{|c|c|c|c|c|c|c|c|c|c|c|c|c|c|c|c|c|}
\hline \multirow{3}{*}{ Morfologias semelhantes } & \multicolumn{16}{|c|}{ Fases experimentais - Pontos de amostragem* } \\
\hline & \multicolumn{3}{|c|}{ Inóculo } & \multicolumn{3}{|c|}{ Adaptação } & \multicolumn{3}{|c|}{$\mathrm{I}$} & \multicolumn{3}{|c|}{ II } & \multicolumn{4}{|c|}{ IV } \\
\hline & $\mathrm{S}$ & $\mathrm{M}$ & $\mathrm{F}$ & $\mathrm{S}$ & $\mathrm{M}$ & $\mathrm{F}$ & & $\mathrm{M}$ & & & $\mathrm{N}$ & $\mathrm{F}$ & & & $\mathrm{M}$ & \\
\hline \multicolumn{17}{|l|}{ Domínio Eukarya } \\
\hline Coco-bacilos & $\mathrm{F}$ & $\mathrm{F}$ & & $\mathrm{R}$ & $\mathrm{R}$ & $\mathrm{R}$ & & $\mathrm{P}$ & & & I & $\mathrm{P}$ & & $F$ & $\mathrm{~F}$ & \\
\hline Bacilos & $\mathrm{A}$ & A & A & $\mathrm{F}$ & $\mathrm{F}$ & $\mathrm{F}$ & A & A & A & & & $A$ & & $\mathrm{~F}$ & $\mathrm{~F}$ & $\mathrm{~F}$ \\
\hline Filamentos & - & - & - & - & - & $\mathrm{R}$ & $\mathrm{R}$ & $\mathrm{R}$ & $\mathrm{P}$ & & $\mathrm{I}$ & $\mathrm{P}$ & & $\mathrm{F}$ & $\mathrm{F}$ & $\mathrm{P}$ \\
\hline \multicolumn{17}{|l|}{ Domínio Archaea } \\
\hline Methanosaeta & $\mathrm{F}$ & $\mathrm{F}$ & $\mathrm{F}$ & $\mathrm{F}$ & $\mathrm{F}$ & A & A & A & & & $A$ & A & & A & A & \\
\hline Methanosarcina & $\mathrm{F}$ & $\mathrm{F}$ & $\mathrm{F}$ & - & - & - & $\mathrm{F}$ & $\mathrm{F}$ & $\mathrm{F}$ & & & $\mathrm{F}$ & & - & - & \\
\hline Bacilos fluorescentes & - & - & - & - & - & - & $\mathrm{F}$ & $\mathrm{F}$ & $\mathrm{F}$ & & $\mathrm{I}$ & $\mathrm{F}$ & & - & - & \\
\hline Bacilo curvo (BRS) & - & $\mathrm{R}$ & $\mathrm{R}$ & - & - & - & $\mathrm{P}$ & $\mathrm{P}$ & $\mathrm{P}$ & & & $\mathrm{P}$ & & $\mathrm{F}$ & $\mathrm{F}$ & $\mathrm{P}$ \\
\hline \multicolumn{17}{|l|}{ Outros } \\
\hline Saccharomyces cereavise & - & - & - & - & - & - & $\mathrm{F}$ & $\mathrm{P}$ & $\mathrm{P}$ & & $\mathrm{F}$ & s & & & $\mathrm{R}$ & \\
\hline
\end{tabular}

*Pontos de amostragem da biomassa do reator: $\mathrm{S}$ - superfície, $\mathrm{M}$ - meio, $\mathrm{F}$ - fundo. Incidência: (A) Abundante, (F) Freqüiente, (P) Pouco frequiente, (R) Raro, (-) Não Observado.

Na Figura 5.66 estão apresentadas as morfologias que foram mais observadas em microscopia ótica. 


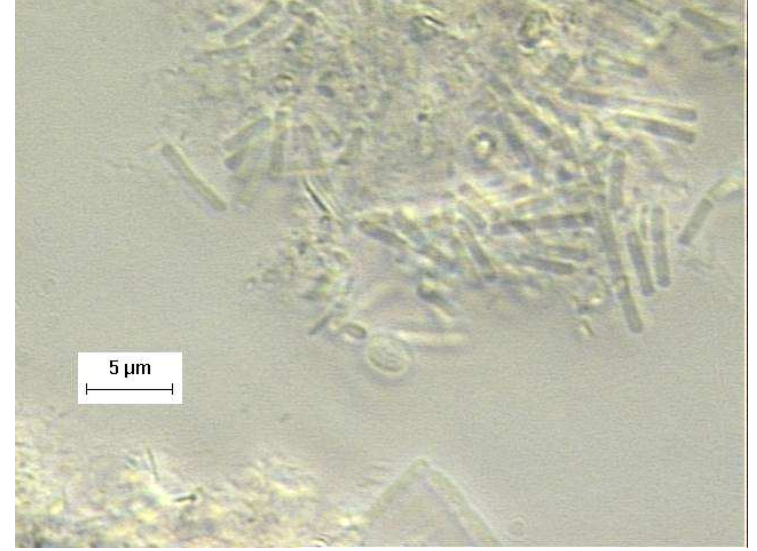

(a)

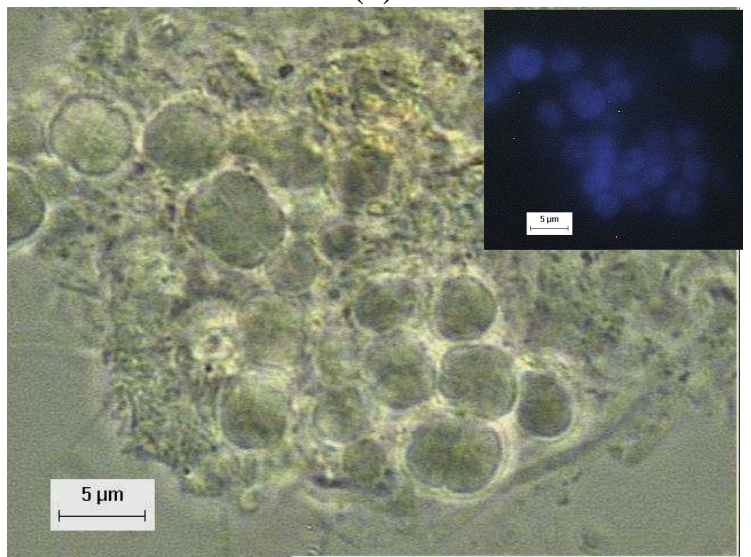

(c)

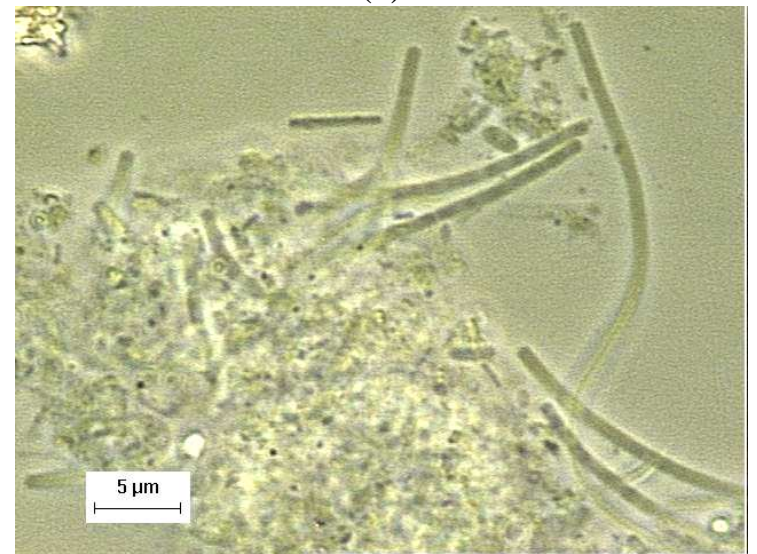

(e)

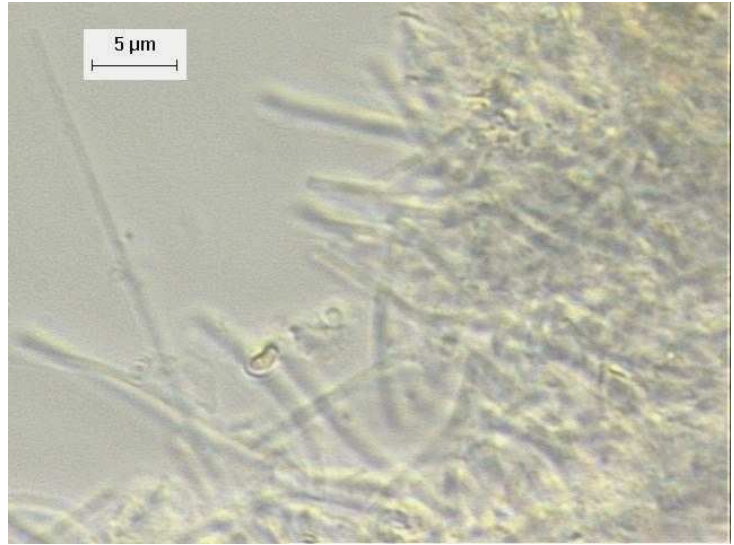

(b)

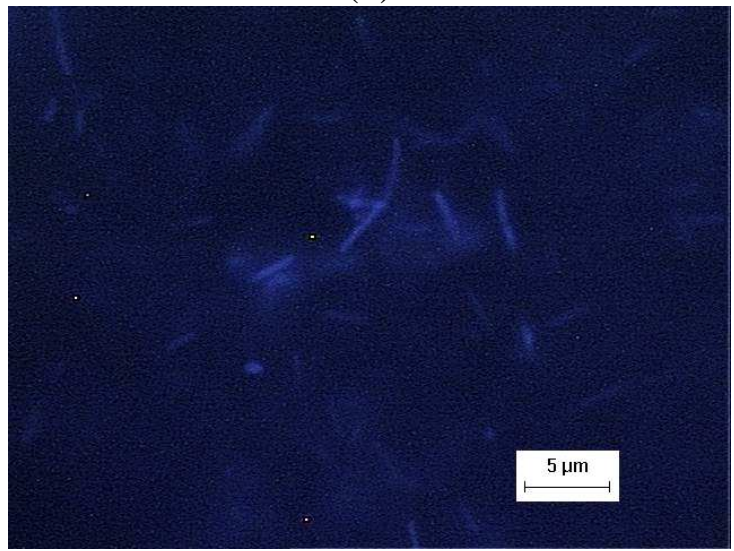

(d)

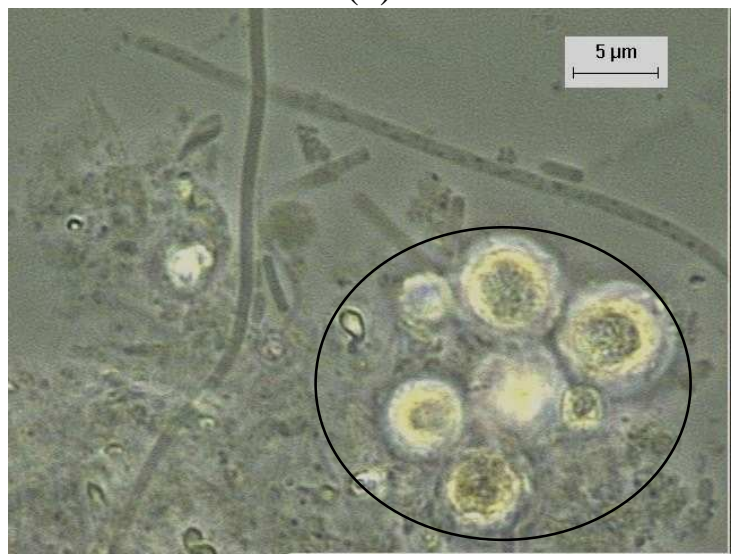

(f)

Figura 5.66 - Morfologias observadas por microscopia óptica de contraste de fases e fluorescência com aumento de 1500X: (a) bacilos - fase I, (b) células semelhantes à Methanosaeta - fase I, (c) células semelhantes à Methanosarcina e em detalhe fluorescência de c - fase II, (d) bacilos fluorescentes - fase II, (e) células semelhantes à Methanosaeta, (f) células semelhantes à Methanosaeta e leveduras (em destaque).

A análise de sólidos voláteis totais dos grânulos que compunham o lodo anaeróbio usado como inóculo revelou que havia em média 31,8 g de SVT/L. No momento da inoculação em que os grânulos foram macerados e misturados às espumas de poliuretano, os sólidos voláteis eram de $0,2 \mathrm{~g} / \mathrm{g}$ de espuma. 
Os SVT da biomassa mesofílica desenvolvida no suporte foram monitorados em algumas fases experimentais desde a fase de adaptação à fase IV e estão apresentados na Tabela 5.23.

Tabela 5.23 - Valores médios de sólidos voláteis totais das espumas de poliuretano obtidos ao final das fases experimentais sob condições mesofílicas.

\begin{tabular}{lcccc}
\hline \multirow{2}{*}{ Parâmetro } & \multicolumn{4}{c}{ Fases } \\
\cline { 2 - 5 } & Adaptação & I & II & IV \\
\hline ST (g/g de espuma) & 3,6 & 1,5 & 1,5 & 3,5 \\
SVT (g/g de espuma) & 0,7 & 0,4 & 0,3 & 0,6 \\
SVT/ST & 0,18 & 0,27 & 0,22 & 0,28 \\
S/X* & 0,18 & 0,24 & 0,66 & 0,58 \\
\hline
\end{tabular}

* relação substrato/microrganismos em g de DQO/g de SVT.

Observou-se que os sólidos voláteis representaram entre 18 a $28 \%$, na fase de adaptação e fase IV, respectivamente, de todos os sólidos presentes na espuma como indicado pela relação entre os SVT/ST.

\subsubsection{Determinação dos parâmetros cinéticos aparentes sob condições mesofílicas} $\left(35^{\circ} \mathrm{C}\right)$

Assim como na fase termofílica, os dados obtidos dos perfis temporais de DQO de cada fase experimental da operação do reator sob condições mesofílicas também foram analisados pelo ajuste do modelo cinético de primeira ordem para estimar os parâmetros cinéticos aparentes.

Na Tabela 5.24, estão apresentados os parâmetros estimados dos perfis temporais de DQO realizados durante algumas fases experimentais da operação do ASBBR sob condições mesofílicas.

Tabela 5.24 - Parâmetros cinéticos aparentes estimados de decaimento de DQO em cada fase experimental tratando vinhaça de cana-de-açúcar em ASBBR mesofílico.

\begin{tabular}{cccccc}
\hline Fase experimental & $\mathrm{COV}^{*}(\mathrm{~g} / \mathrm{L} . \mathrm{d})$ & $\mathrm{C}_{\mathrm{So}} *(\mathrm{~g} / \mathrm{L})$ & $\mathrm{C}_{\mathrm{SR}}(\mathrm{g} / \mathrm{L})$ & $\mathrm{K}_{1}{ }^{\text {app }}\left(\mathrm{h}^{-1}\right)$ & $\mathrm{R}^{2}$ \\
\hline $\mathrm{I}$ & 2,79 & 2,79 & $0,84 \pm 0,11$ & $1,243 \pm 0,24$ & 0,95 \\
$\mathrm{II}$ & 6,44 & 6,44 & $1,59 \pm 0,27$ & $1,161 \pm 0,41$ & 0,84 \\
IV $^{1}$ & 10,56 & 10,56 & $2,14 \pm 0,25$ & $0,656 \pm 0,13$ & 0,96 \\
& & & $3,07 \pm 0,51$ & $0,687 \pm 0,22$ & 0,91 \\
\hline
\end{tabular}

${ }^{1}$ - perfis realizados nos ciclos 75 e $82 ; *$ dados experimentais. 
Os dados apresentados na Tabela 5.24 se referem aos ajustes feitos com estimativa de $\mathrm{k}_{1}{ }^{\text {app }}$ e $\mathrm{C}_{\mathrm{SR}}$ aos dados experimentais que apresentaram os melhores resultados quando se estimou somente a constante $\mathrm{k}_{1}{ }^{\text {app }}$.

De acordo com os ajustes aos dados experimentais, pode-se observar que, entre as fases I e II, o aumento da COV não afetou significativamente a constante cinética aparente de primeira ordem $\left(\mathrm{k}_{1}{ }^{\mathrm{app}}\right)$, mas, na fase $\mathrm{IV}$, com COV média para 10,56 gDQO/L.d, houve diminuição da constante nos perfis realizados nos ciclos 75 e no 82 (Tabela 5.24).

A Figura 5.67 mostra as curvas correspondentes ao modelo ajustado aos dados experimentais quanto ao decaimento de DQO em ASBBR mesofílico.

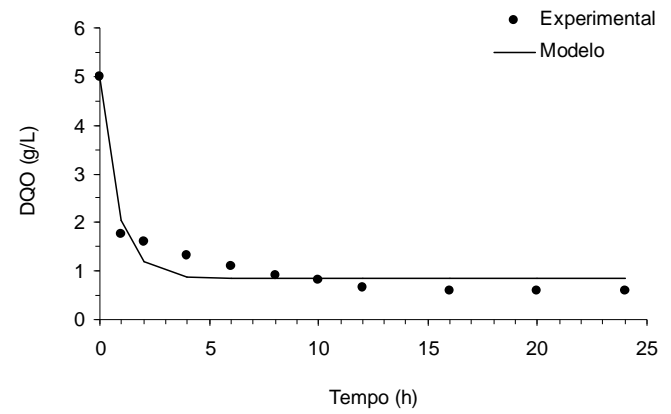

(a)

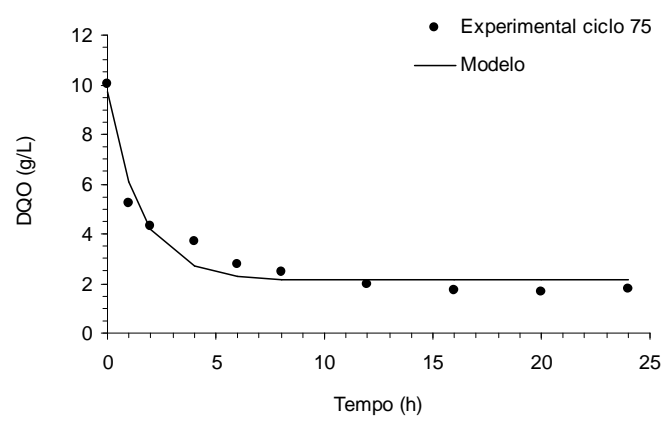

(c)

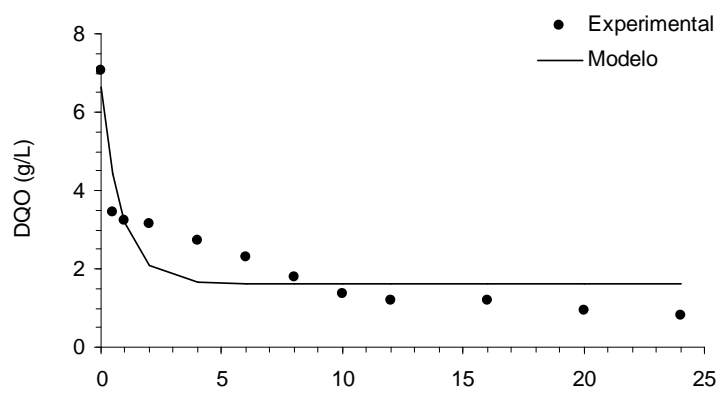

(b)

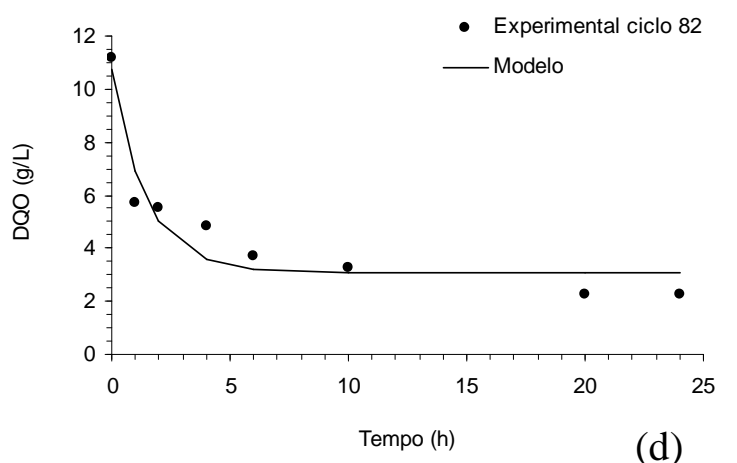

(d)

Figura 5.67 - Ajuste do modelo cinético de primeira ordem aos dados experimentais de decaimento de DQO sob condições mesofílicas: (a) fase I - 2,79 gDQO/L.d, (b) fase II - 6,44 gDQO/L.d, (c) perfil do ciclo 75 - fase IV - 10,56 gDQO/L.d, (d) réplica de (c) perfil do ciclo 82 . 


\subsection{Comparação de desempenho do reator anaeróbio operado em batelada seqüencial contendo biomassa imobilizada sob condições termofílicas $\left(55^{\circ} \mathrm{C}\right)$ e mesofílicas $\left(35^{\circ} \mathrm{C}\right)$}

De forma geral, o tratamento da vinhaça gerada no processamento do álcool da cana-de-açúcar foi passível de tratamento tanto em condições termofílicas como mesofílicas.

A apresentação e discussão dos resultados serão feitas em tópicos a fim de facilitar as observações de acordo com cada parâmetro avaliado e comparado.

\section{- COV e eficiência de remoção de DQO}

A variação de COV aplicada, em cada fase experimental (Figura 5.68) pode ser atribuída à heterogeneidade da água residuária que pode mudar em cada recipiente onde a vinhaça foi coletada na usina e armazenada até a utilização, ou de acordo com a intensidade de homogeneização do resíduo no momento da diluição durante o preparo do substrato do reator, por possuir grande quantidade de sólidos sedimentados, entre outros possíveis fatores.

Pode-se observar que em condição mesofílica, o reator alcançou eficiências maiores de remoção de DQO em período mais curto, suportou cargas orgânicas superiores e apresentou maior estabilidade nas mudanças de fases que o reator termofílico.

O reator operado a $35{ }^{\circ} \mathrm{C}$ começou a ser alimentado com vinhaça de cana-deaçúcar aos 17 dias ( $17^{\circ}$ ciclo) na carga orgânica volumétrica de 2,5 g/L.d enquanto o reator que operava a $55^{\circ} \mathrm{C}$, partiu com vinhaça aos 50 dias com COV de 1,0 g/L.d (39 ciclo).

Na Figura 5.68, observam-se os valores das cargas orgânicas reais às quais o reator foi submetido em cada ciclo analisado e as eficiências de remoção obtidas. 


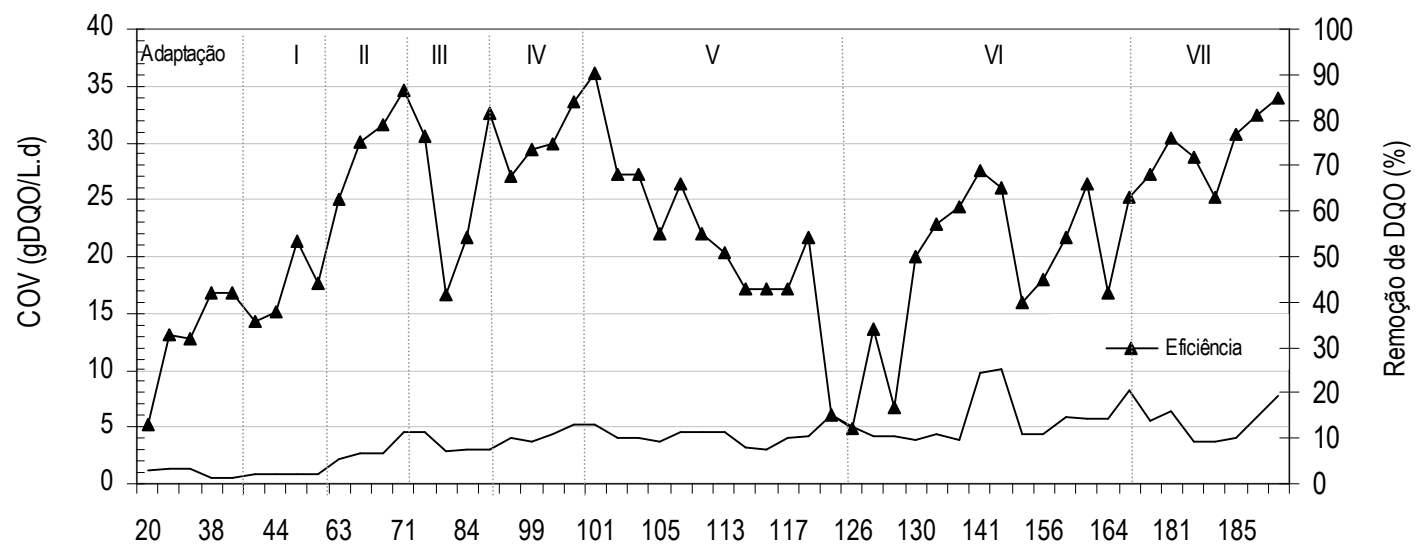

Ciclos

(a)

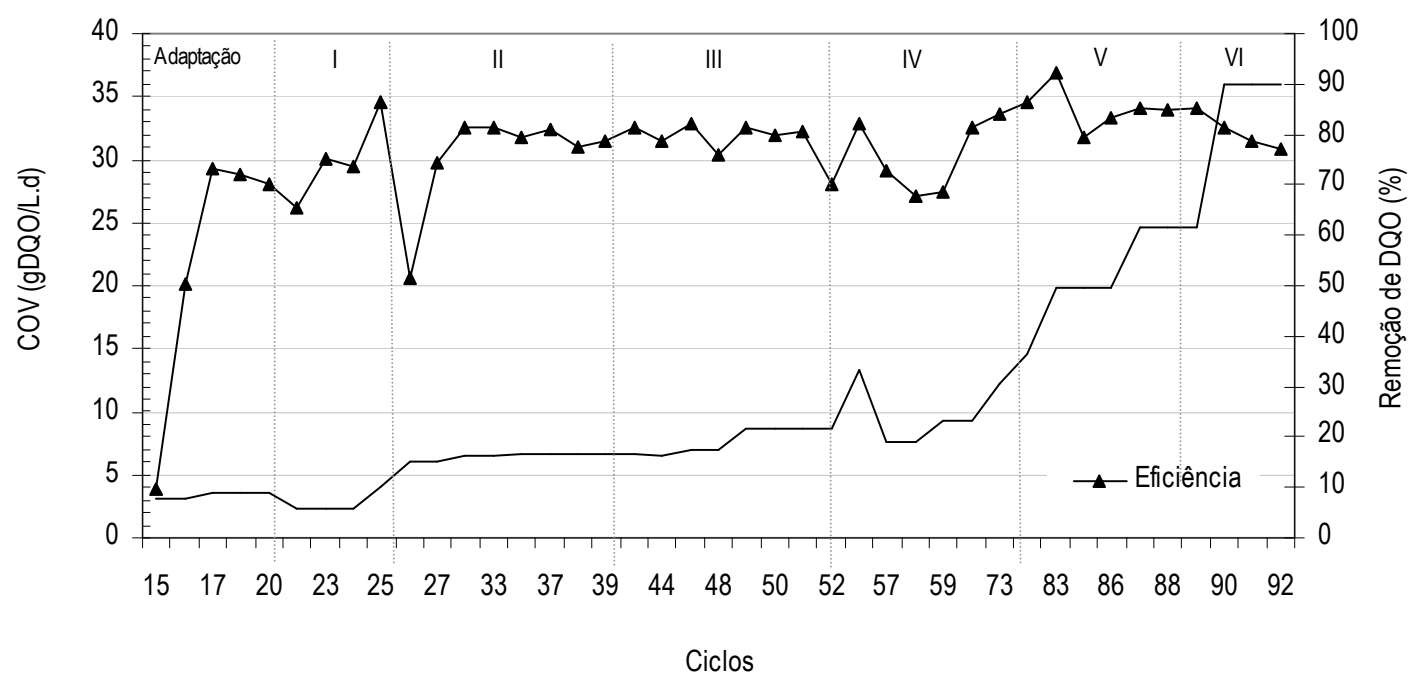

(b)

Figura 5.68 - Carga orgânica volumétrica aplicada ao ASBBR e eficiência de remoção de DQO sob condições (a) termofílicas e (b) mesofílicas.

Observa-se, na Figura 5.69, que os valores de desvio padrão obtidos no reator mesofílico foram menores que o termofílico, o que possibilita inferir que houve menor variação da eficiência naquelas condições e maior estabilidade. 


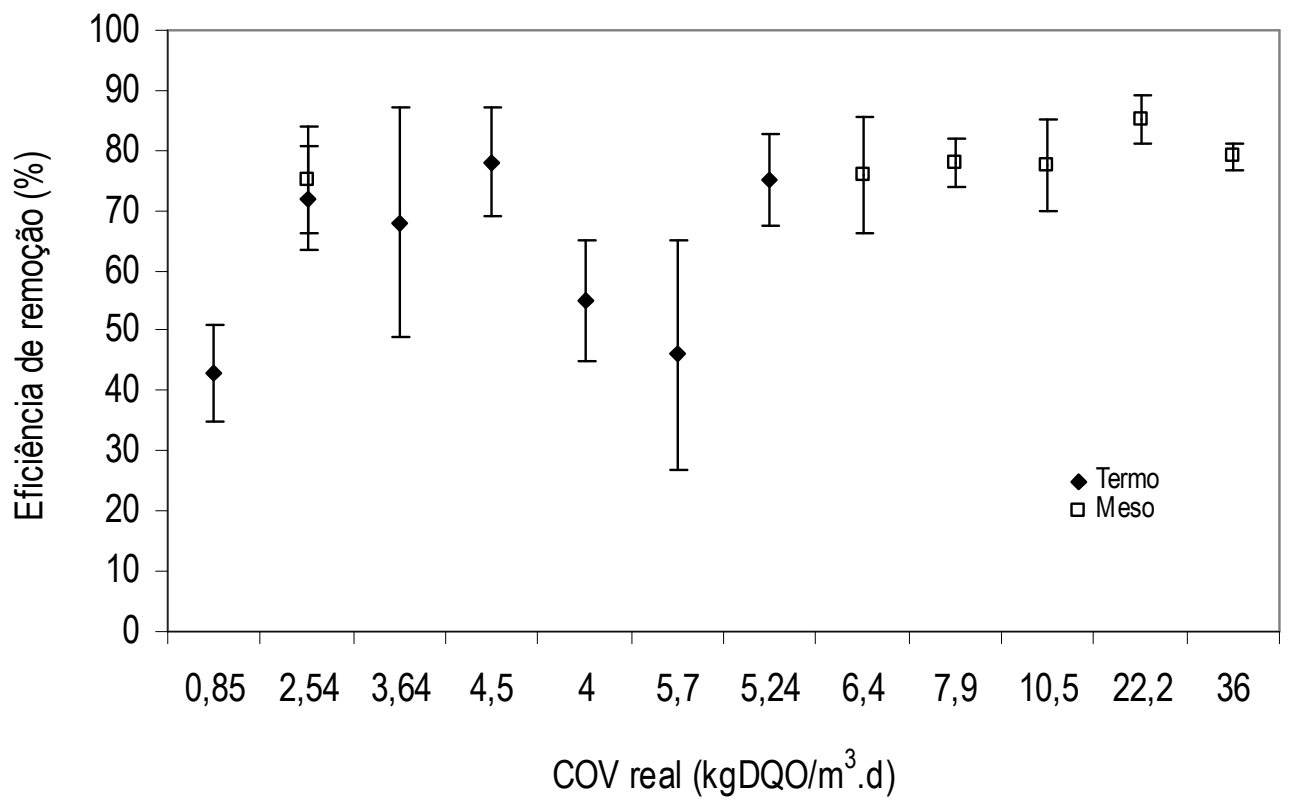

Figura 5.69 - Eficiência de remoção média de DQO e COV aplicada em ASBBR termofílico e mesofílico.

A maior capacidade de adaptação do inóculo mesofílico usado no tratamento da vinhaça de cana, obtida pelo reator mesofílico confirmou os resultados obtidos no ensaio de biodegradabilidade anaeróbia metanogênica com lodo granular tratando substrato sintético semelhante à vinhaça de beterraba que serão apresentados no próximo item.

A COV máxima alcançada pelo reator termofílico foi de $5,7 \mathrm{~kg} / \mathrm{m}^{3} . \mathrm{d}$ com $46 \%$ de eficiência média de remoção na fase VI (ciclo 169) com 263 dias de operação e pelo mesofílico foi de $36 \mathrm{~kg} / \mathrm{m}^{3}$.d com $79 \%$ de remoção na fase VI em 90 dias de operação.

Ahn \& Forster (2000) operaram filtros anaeróbios ascendentes em temperatura termofílica $\left(55^{\circ} \mathrm{C}\right)$ e mesofílica $\left(35^{\circ} \mathrm{C}\right)$ alimentado com substrato rico em amido com cargas orgânicas de 1,2 a 17,2 kg DQO/m³ .d por 230 dias. Entre as cargas orgânicas de 1,2 e $8,3 \mathrm{~kg} \mathrm{DQO} / \mathrm{m}^{3}$.d não houve diferença significativa entre a performance dos reatores, mas na carga de 12,4 e de $17,0 \mathrm{~kg}$ DQO $/ \mathrm{m}^{3} . \mathrm{d}$ o filtro mesofílico mostrou diminuição da eficiência de remoção de DQO e da produção de biogás e formação de ácido butírico.

Em trabalho posterior, Ahn \& Forster (2002) conseguiram tratar licor da polpa de papel nos filtros anaeróbios termofílico e mesofílico com TRH de 11,7 a 26,2 horas e carga orgânica de 1,70 a $3,87 \mathrm{~kg} \mathrm{DQO} / \mathrm{m}^{3}$.d. O reator termofílico mostrou significante aumento no desempenho de DQO solúvel, com incrementos de TRH, enquanto que o 
reator mesofílico não apresentou aumento. As taxas de produção específicas de metano da biomassa do filtro termofílico foram mais altas que do mesofílico em todos os tempos de retenção.

Desempenho semelhante foi obtido por Harris \& Dague (1993) que alcançaram melhor desempenho no filtro anaeróbio termofílico na carga orgânica de $13,75 \mathrm{~kg}$ DQO $/ \mathrm{m}^{3}$.d com remoção de DQO solúvel de $75 \%$, enquanto que o filtro mesofílico atingiu $48 \%$ na mesma carga. Mesmo assim, os autores relataram que o filtro termofílico produziu efluente com maior concentração de ácidos voláteis em 150 $\mathrm{mg} / \mathrm{L}$ que o efluente do filtro mesofílico.

Possivelmente os reatores mesofílicos desses trabalhos tenham apresentado menor desempenho com o tratamento termofílico devido à fase de hidrólise de compostos complexos como amido, que afeta a fase acidogênica e, por conseguinte, a fase metanogênica. Em muitos casos, as fases iniciais do sistema anaeróbio podem ser limitantes do processo, que pode se acentuar quando a água residuária é constituída de materiais complexos, em alta carga orgânica e tempo de detenção curto e quando o lodo anaeróbio for deficiente em diversidade microbiana.

Dinsdale et al. (1997) compararam o desempenho do reator UASB em temperatura mesofílica e termofílica tratando água residuária gerada na produção de café instantâneo. Os autores obtiveram bom desempenho do termofílico em 28 dias de operação. Até a carga orgânica de $10 \mathrm{~kg}$ DQO $/ \mathrm{m}^{3}$.d (TRH de 24 horas), ambos reatores apresentaram comportamento semelhante. O termofílico suportou até a COV de 11,4 kg/L.d (TRH 21 horas), mas a partir de 13,3 kgDQO/m³. $\mathrm{d}$ (TRH de 18 horas) foi observado um aumento dos ácidos voláteis totais de 80 para $600 \mathrm{mg} / \mathrm{L}$.

De modo geral, os autores observaram que a eficiência de remoção de DQO no UASB termofílico foi ligeiramente menor com maior ácidos voláteis em todas as cargas orgânicas aplicadas, alcançando uma remoção de $70 \%$ e 100 mgHAc/L contra $78 \%$ e $25 \mathrm{mgHAc} / \mathrm{L}$ no UASB mesofílico.

Viana (2006) tratou vinhaça de cana-de-açúcar em UASB termofílico $\left(55^{\circ} \mathrm{C}\right)$ com TDH de 24 horas aplicando COV de 0,3 a 6,5 g DQO/L.d num tempo de funcionamento total de 200 dias e, observou que houve estabilidade operacional do reator até a COV de 5,0 g/L.d com remoção média de $50 \%$. Na COV de 6,5 g/L.d o autor observou queda de eficiência na remoção de DQO de $40 \%$ e aumento de ácidos voláteis totais de 800 (na COV de 5,0 g/L.d) para $1200 \mathrm{mg} / \mathrm{L}$ (na COV de 6,5 g/L.d), apesar de não ter observado queda nos valores de $\mathrm{pH}$ e de alcalinidade a bicarbonato. 
Portanto, comparando-se os resultados experimentais obtidos com a literatura, observa-se que no tratamento anaeróbio de vinhaça, o desempenho do ASBBR operado a $35^{\circ} \mathrm{C}$ apresentou melhores resultados, muito embora, outros autores que trabalharam com outras águas residuárias tenham concluído que o sistema termofílico tenha apresentado maiores vantagens sob o mesofílico.

\section{$-p H$}

Observou-se que na fase de maior estabilidade do reator termofílico (fases III, IV e V), o pH variou de 8,2 a 8,5 e do mesofílico em todas as fases ficaram abaixo de 8,0 .

No trabalho desenvolvido por Song et al. (2004) com lodo de esgoto, o pH medido de processos termofílicos sempre era mais alto $(8,08)$ que mesofílicos $(7,67)$. $\mathrm{O}$ mesmo comportamento foi observado com os valores de alcalinidade que em média foram de 6875 contra $6412 \mathrm{mg} \mathrm{CaCO}_{3} / \mathrm{L}$ nos resíduos finais do processo mesofílico. Os autores citam que o $\mathrm{pH}$ é resultado dos valores de alcalinidade da digestão anaeróbia termofílica que é gerada a partir da degradação de compostos orgânicos, redução de sulfato e liberação de ortofosfato.

Mesmo operando o sistema em $\mathrm{pH}$ maior que o recomendado para microrganismos anaeróbios (entre 6,8 e 7,4), os autores não observaram efeito negativo na eficiência do sistema. Além disso, foi observado propionato no efluente e maior pressão parcial de hidrogênio. Claramente, os autores concluíram que o mesofílico apresentou melhor qualidade do efluente, maior rendimento de metano no biogás e estabilidade operacional. Em compensação, o termofílico apresentou maior redução de sólidos voláteis e redução de coliformes fecais.

Paulo et al. (2003) citam que a faixa ótima de pH para o crescimento de metanogênicos termofílicos se situa entre 6,5 e 8,0 e dos homoacetogênicos entre 5,8 e 7,0 .

De acordo com as respostas dos reatores frente ao carregamento orgânico e com a quantidade de bicarbonato adicionado ao sistema (Tabela 5.25 e Figura 5.70), ficou evidenciada a maior estabilidade operacional do reator operado a $35^{\circ} \mathrm{C}$ no tratamento anaeróbio da vinhaça de cana-de-açúcar utilizada como substrato neste trabalho. 


\section{- Alcalinidade a bicarbonato}

Ao longo de todo período experimental foram necessárias adições de substâncias alcalinizantes e com base na literatura, optou-se pela adição de bicarbonato de sódio devido a melhores vantagens ao sistema anaeróbio (SPEECE, 1996, GRIFFIN et al., 1998, TORRES et al.,2005).

A seguir estão apresentados os dados quanto à quantidade aplicada no ASBBR termofílico e mesofílico na Tabela 5.25.

Tabela 5.25 - Quantidade de bicarbonato adicionada em relação à DQO em ASBBR termofílico e mesofílico.

\begin{tabular}{|c|c|c|c|c|c|c|}
\hline \multirow[b]{2}{*}{ Fases } & \multicolumn{3}{|c|}{ Termofílico } & \multicolumn{3}{|c|}{ Mesofílico } \\
\hline & $\begin{array}{l}\text { COV } \\
\text { (g/L.d) }\end{array}$ & $\begin{array}{c}\mathrm{gHCO}_{3}{ }^{-} / \\
\mathrm{gDQO}\end{array}$ & $\begin{array}{c}\mathrm{gHCO}_{3}^{-} \\
/ \mathrm{L} . \mathrm{d}\end{array}$ & $\begin{array}{l}\text { COV } \\
\text { (g/L.d) }\end{array}$ & $\begin{array}{c}\mathrm{gHCO}_{3}{ }^{-} / \\
\mathrm{gDQO}\end{array}$ & $\begin{array}{c}\mathrm{gHCO}_{3}^{-} \\
\quad / \mathrm{L} . \mathrm{d}\end{array}$ \\
\hline Adaptação & 0,97 & 1,2 & 1,16 & 3,41 & 1 & 3,41 \\
\hline I & 0,85 & 1,2 & 1,02 & 2,79 & 0,4 & 1,12 \\
\hline II & 2,54 & 0,8 & 2,03 & 6,44 & 0,4 & 2,58 \\
\hline III & 3,64 & 0,8 & 2,91 & 7,92 & 0,3 & 2,38 \\
\hline IV & 4,50 & 0,6 & 2,70 & 10,56 & 0,2 & 2,11 \\
\hline $\mathrm{V}$ & 4,00 & 0,6 & 2,40 & 22,23 & 0,2 & 4,45 \\
\hline VI & 5,70 & 0,4 & 2,28 & 35,94 & 0,2 & 7,19 \\
\hline VII & 5,24 & 0,6 & 3,14 & & & \\
\hline
\end{tabular}

A falta de bicarbonato reflete no desempenho total do reator. Paulo et al. (2003) avaliaram o efeito do $\mathrm{pH}$ e do bicarbonato na conversão anaeróbia de metanol sob condições termofílicas e, verificaram que o bicarbonato contribuiu diretamente na conversão do etanol em aproximadamente $50 \%$ do total de metano formado e que $50 \%$ da formação de metano dependeu da ocorrência de bactérias homoacetogênicas que neste caso são restringidas pela quantidade disponível de bicarbonato no sistema.

Assim, a estabilidade do reator mesofílico avaliada nesse trabalho foi verificada não somente pelo desempenho na eficiência de remoção de DQO como também pela alcalinidade a bicarbonato observada no efluente.

Comparando-se a quantidade de bicarbonato adicionado ao afluente do reator, pôde-se verificar comparativamente que houve menor suplementação no reator mesofílico que o termofílico até a carga de $10,5 \mathrm{~kg}$ DQO $/ \mathrm{m}^{3}$.d, conforme ilustrado pela Figura 5.70. 


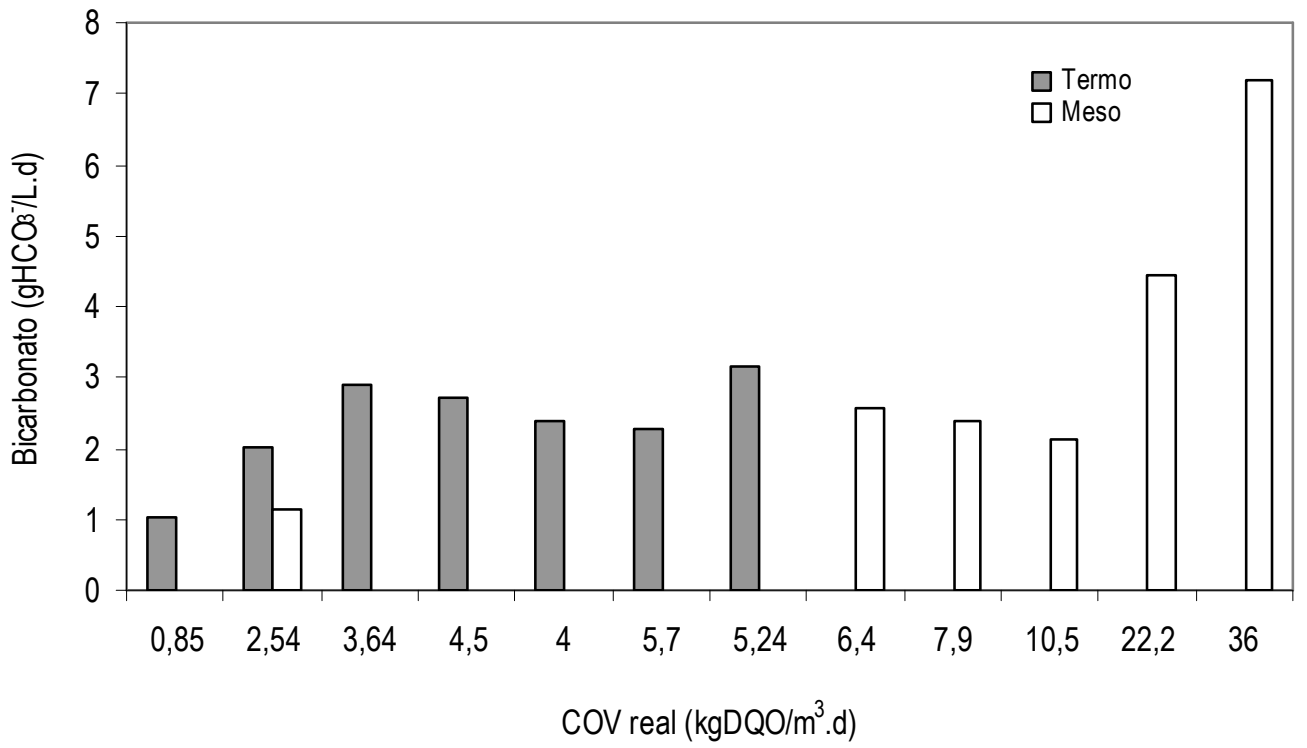

Figura 5.70 - Quantidade de bicarbonato adicionada e DQO em ASBBR termofílico e mesofílico.

No trabalho anteriormente citado, foi observado que a conversão de metanol foi influenciada pelo bicarbonato no consórcio anaeróbio, pois consumiu o $\mathrm{H}_{2}$ ajudando a manter a pressão parcial de hidrogênio baixa para que a reação fosse termodinamicamente favorável e o metanol pudesse ser convertido em $\mathrm{H}_{2} / \mathrm{CO}_{2}$. Isso torna-se especialmente importante no tratamento de águas residuárias que contêm metanol (PAULO et al., 2003)

Mas, em casos eventuais de instabilidade é recomendável adicionar $\mathrm{NaHCO}_{3}$ para manter o $\mathrm{pH}$ próximo à neutralidade (GRIFFIN et al., 1998).

Paulo et al. (2003) também mantiveram o pH do reator UASB próximo ao neutro com $\mathrm{NaOH}$ e observaram mau desempenho e instabilidade do reator e, sugeriram que o pH do sistema anaeróbio seja controlado pela adição de um tampão fosfato de $72 \mathrm{mM}$.

Torres et al. (2005) avaliaram três substâncias alcalinizantes comerciais, a cal hidratada $\left(\mathrm{Ca}(\mathrm{OH})_{2}\right)$, hidróxido de sódio $(\mathrm{NaOH})$ e bicarbonato de sódio $\left(\mathrm{NaHCO}_{3}\right)$, com as finalidades de neutralizar a acidez em $\mathrm{pH} 5,75$ da água residuária do processamento de mandioca e garantir a capacidade tampão de sistemas anaeróbios a baixo custo. As doses de alcalinidade a bicarbonato foram definidas a partir da quantidade mínima que assegurou um valor adequado de atividade metanogênica 
específica (ao redor de 0,20 gDQO/gSVT.d), sendo estes valores de $500 \mathrm{mg} / \mathrm{L}$ para $\mathrm{NaHCO}_{3}, 1000 \mathrm{mg} / \mathrm{L}$ para $\mathrm{NaOH}$ e $1750 \mathrm{mg} / \mathrm{L}$ para $\mathrm{Ca}(\mathrm{OH})_{2}$.

De posse destes dados, os autores realizaram uma análise de custo/benefício, e concluíram que a cal hidratada apresentou menor custo (US\$ $0,16 / \mathrm{m}^{3}$ ), mas requer maior aporte de alcalinidade a bicarbonato o que eleva o custo total (US\$ 0,69/m ${ }^{3}$ ). Já o custo total do $\mathrm{NaOH}$ foi menor comparado com os outros alcalinizantes (US\$ 0,54/ $\mathrm{m}^{3}$ ), mas igual ao custo obtido com bicarbonato de sódio (US\$ $0,54 / \mathrm{m}^{3}$ ).

Por fim, os autores concluíram que considerando o custo/benefício, pode-se afirmar que o bicarbonato de sódio ofereceu os melhores resultados para garantir a capacidade tampão do sistema, tem vantagens sobre os outros alcalinizantes por ser bastante solúvel, de fácil manipulação e evita problemas de vácuo no sistema como ocorre com o $\mathrm{NaOH}$ que ao reagir com $\mathrm{CO}_{2}$ do meio provoca diminuição da pressão interna do sistema.

\section{- Sódio}

Como a fonte de bicarbonato usada no presente trabalho experimental foi bicarbonato de sódio, sabe-se que o íon de sódio, $\mathrm{Na}^{+}$, a partir da concentração de 3500 $\mathrm{mg} / \mathrm{L}$ pode apresentar toxicidade a biomassa anaeróbia (McCARTY, 19648 apud GRIFFIN et al., 1998). Baseando-se nesta hipótese, calculou-se a quantidade teórica de $\mathrm{Na}^{+}$que foi adicionada em cada fase experimental (Tabela 5.26).

Tabela 5.26 - Quantidade de $\mathrm{Na}^{+}$adicionada no afluente junto com o bicarbonato em cada fase experimental nos reatores termofílico e mesofílico.

\begin{tabular}{ccc}
\hline \multirow{2}{*}{ Fase } & \multicolumn{2}{c}{$\mathbf{m g ~ N a}^{+} / \mathbf{L}$} \\
\cline { 2 - 3 } & Termofílico & Mesofílico \\
\hline Adaptação & 534 & 1286 \\
I & 385 & 421 \\
II & 766 & 971 \\
III & 1647 & 896 \\
IV & 3047 & 796 \\
V & 5425 & 1676 \\
VI & 1816 & 2710 \\
VII & 2369 & - \\
\hline
\end{tabular}

Observa-se que na quinta fase do reator termofílico foi adicionado grande quantidade de $\mathrm{Na}^{+}$que pode também ter prejudicado os microrganismos anaeróbios

\footnotetext{
${ }^{8}$ McCarty, P.L. (1964). Anaerobic waste treatment fundamentals. Public Works, 325-344.
} 
contribuindo com a COV para uma queda brusca de desempenho do reator. Já no reator mesofílico observa-se que o $\mathrm{Na}^{+}$adicionado não ultrapassou o nível de toxicidade citado.

Olmo (2005) estudou o efeito do sódio sobre o tratamento de água residuária de charqueada em elevada salinidade em reatores UASB e, observou que o desempenho dos reatores quanto a remoção de matéria orgânica não foi alterado até a concentração de $\mathrm{NaCl}$ de $6000 \mathrm{mg} / \mathrm{L}$, pois a autora trabalhou com cargas de sódio crescentes com o objetivo de adaptar uma biomassa capaz de se desenvolver em elevadas concentrações de sódio e de consumir a matéria orgânica presente na água residuária oriunda do sangue das carnes processadas.

\section{- Exames morfológicos}

Outra diferença interessante que foi observada nesse trabalho entre os reatores termofílico e mesofílico foi quanto às morfologias observadas nos exames de microscopia ótica realizados.

Observou-se que ao fim dos experimentos, o reator termofílico era colonizado por arquéias semelhantes à Methanosarcina, enquanto que o reator mesofílico selecionou arquéias do tipo Methanosaeta.

Griffin et al. (1998) avaliaram a dinâmica populacional metanogênica durante a partida de reatores tratando resíduos sólidos orgânicos e biosólidos e, verificaram por hibridizações, que no reator mesofílico predominaram Methanosarcina $(11,6 \%)$ quando houve maior concentração de acetato devido maiores taxas de crescimento, enquanto, a população de Methanosaeta estava presente em 0,2 \%. Os autores destacaram que em altas concentrações de acetato, dentre as metanogênicas, há predomínio de Methanosarcina.

No mesmo trabalho, os autores observaram no reator termofílico que os níveis de Methanosaeta e Methanomicrobiales diminuíram durante os primeiros dias, indicando que a taxa de remoção por arraste da biomassa era maior que suas taxas de crescimento. Isso foi compensado pelo aumento de Methanobacteriaceae e de Methanococcaceae no reator.

Cabirol et al. (2003) examinaram o lodo anaeróbio mesofílico de uma estação de tratamento de água residuária de cervejaria durante a adaptação de um reator UASB em condições termofílicas usando a técnica do PCR (do inglês, polymerase chain reaction) para detecção do gênero e, puderam constatar que as metanogênicas hidrogenotróficas 
tenderam a predominar nessas condições (tais como Methanospirillum, Methanobacterium e Methanobrevibacter).

Viana (2006) também observou que houve colonização predominante de arquéias do gênero Methanosarcina no lodo biológico de um reator UASB sob condições termofílicas tratando vinhaça de cana-de-açúcar. E, nesse período o autor não observou instabilidade operacional.

Diante das morfologias observadas e do desempenho do reator obtido nesse trabalho e, das morfologias que foi observado por Viana (2006), pode-se inferir que, a instabilidade observada no ASBBR termofílico, pode estar associada à conjunção dos fatores composição da biomassa metanogênica e características físicas e operacionais dessa configuração de reator, pois o reator UASB operado por Viana (2006) selecionou basicamente arquéias do gênero Methanosarcina e apresentou bons resultados de desempenho.

\section{- Parâmetros cinéticos}

Com relação aos parâmetros cinéticos, de modo geral, a constante cinética aparente de primeira ordem obtida após ajuste do modelo cinético aos dados experimentais de redução de DQO foi maior quando o reator foi operado sob condição mesofílica que termofílica, como pode ser observado na Tabela 5.27. Além disso, o reator operado sob condições mesofílicas foi submetido a valores de COV superiores àquelas aplicadas em condições termofílicas.

Tabela 5.27 - Parâmetros cinéticos aparentes estimados de decaimento de DQO em ASBBR termofílico e mesofílico.

\begin{tabular}{ccc|ccc}
\hline \multicolumn{3}{c|}{ Termofílico } & \multicolumn{3}{c}{ Mesofílico } \\
\hline $\mathrm{COV}^{*}(\mathrm{~g} / \mathrm{L} . \mathrm{d})$ & $\mathrm{k}_{1}{ }^{\text {app }}\left(\mathrm{h}^{-1}\right)$ & $\mathrm{R}^{2}$ & $\mathrm{COV}^{*}(\mathrm{~g} / \mathrm{L} . \mathrm{d})$ & $\mathrm{k}_{1}{ }^{\mathrm{app}}\left(\mathrm{h}^{-1}\right)$ & $\mathrm{R}^{2}$ \\
\hline 0,85 & $0,194 \pm 0,03$ & 0,89 & 2,79 & $1,243 \pm 0,24$ & 0,95 \\
2,54 & $0,151 \pm 0,02$ & 0,97 & 6,44 & $1,161 \pm 0,41$ & 0,84 \\
3,64 & $0,105 \pm 0,02$ & 0,93 & & $0,656 \pm 0,13$ & 0,96 \\
4,50 & $0,049 \pm 0,01$ & 0,91 & 10,56 & $0,687 \pm 0,22$ & 0,91 \\
5,24 & $0,085 \pm 0,03$ & 0,91 & - & - & - \\
\hline
\end{tabular}

Van Lier (1995) citou que os valores dos parâmetros cinéticos de termófilos geralmente são superiores aos de mesófilos, o que não foi observado neste caso. Apesar de os resultados obtidos de não estarem de acordo com o relato da literatura, observa-se que os valores obtidos são condizentes com o desempenho dos reatores. 


\subsection{Considerações finais}

Com relação à operação do ASBBR termofílico, a maior COV que pôde ser aplicada sem que ocorressem instabilidades operacionais e sem consequiente queda significativa de desempenho foi de 5,0 g/L.d. Esse valor é inferior aos valores de COV relatados na literatura para a maioria dos trabalhos de tratamento anaeróbio de vinhaça de cana-de-açúcar sob condições termofílicas.

O maior problema do sistema quando operado sob condições termofílicas foi a instabilidade do processo, que pode estar relacionada com o decaimento microbiano, especialmente da biomassa metanogênica, que é maior em temperaturas mais elevadas, devido à aceleração das reações químicas e bioquímicas (VAN LIER, 1995).

Segundo Speece (1996) o maior problema do processo anaeróbio termofílico refere-se ao baixo coeficiente líquido de produção celular da biomassa, que é apenas $50 \%$ do valor a $35^{\circ} \mathrm{C}$.

O decaimento mais rápido da população metanogênica, por crescer mais lentamente que as populações hidrolíticas e fermentativas, resulta em desbalanceamento inicial entre a produção e o consumo de ácidos (POHLAND \& GHOSH, 1971). Para temperaturas inferiores, em que a velocidade de decaimento é menor, esse problema também é reduzido.

Isso parece ser uma explicação razoável inclusive para o acúmulo de ácido propiônico, que ocorre porque os microrganismos hidrogenotróficos não conseguem consumir todo hidrogênio produzido.

Caso a população hidrogenotrófica tenha sofrido decaimento severo devido à temperatura, o hidrogênio deixará de ser consumido na proporção em que é produzido, resultando na paralisação dos microrganismos acetogênicos que convertem o propionato a acetato (GIFFIN et al., 1998) e, consequentemente, haverá acúmulo de ácido propiônico no sistema (VAN LIER, 1995).

Nas condições experimentais estudadas, o ASBBR mesofílico apresentou excelente desempenho na remoção de DQO, atingindo COV de 36 g/L.d em curto espaço de tempo, 90 dias, o que viabiliza o tratamento dessa água residuária em condições mesofílicas. 


\section{Conclusões}

“De tudo, ficaram três coisas: a certeza de que estamos sempre
começando, de que temos que continuar e podemos ser
interrompidos a qualquer momento. Fazer da interrupção um
novo caminho, da queda um passo de dança, do sonho uma
ponte e da procura, um encontro."

Fernando Sabino

Com base em todos os resultados obtidos, pode-se afirmar que, nas condições experimentais avaliadas, em que foi submetido às temperaturas mesofílica e termofilica, o reator anaeróbio contendo biomassa imobilizada e, operado em bateladas seqüenciais (ASBBR), mostrou-se eficiente no tratamento de vinhaça de usina de açúcar e álcool.

Outras conclusões mais específicas podem ser destacadas como:

- A COV máxima alcançada pelo reator operado na temperatura termofílica, em condições de estabilidade operacional, foi de $5,7 \mathrm{~kg} / \mathrm{m}^{3}$.d, obtendo-se $46 \%$ de eficiência média de remoção. A COV máxima aplicada ao reator operado na temperatura mesofílica foi de $36 \mathrm{~kg} / \mathrm{m}^{3} . \mathrm{d}$, obtendo-se $79 \%$ de remoção de DQO;

- A instabilidade operacional que foi observada em alguns momentos quando o reator foi operado em temperatura na faixa termofílica foi associada ao acúmulo de ácidos voláteis totais. Sendo que em alguns perfis temporais foi observado acúmulo, principalmente de ácido propiônico, cujas concentrações atingiram valores considerados possivelmente prejudiciais à metanogênese;

- Quando operado em temperatura na faixa mesofílica, o reator não apresentou instabilidade operacional, sendo que as quedas de eficiência observadas após os aumentos da COV eram prontamente superadas nas bateladas seguintes; 
- As causas para o desequilíbrio entre as populações formadoras e consumidoras de ácidos voláteis no tratamento termofílico permanecem não completamente esclarecidas, podendo estar relacionadas ao decaimento rápido da biomassa metanogênica, nessa temperatura, devido provavelmente a processos endógenos;

- No reator termofílico, observou-se a formação de fenol em concentrações entre 3 e $7 \mathrm{mg} / \mathrm{L}$, a partir da COV de 2,5 gDQO/L. Os efluentes do reator mesofílico apresentaram valores de fenol inferiores a $0,8 \mu \mathrm{g} / \mathrm{L}$;

- Os valores de $\mathrm{pH}$ efluente do reator termofílico variaram de 8,2 a 8,5 e do mesofílico mantiveram-se entre 7,0 e 8,0;

- Os resultados obtidos permitiram constatar que a demanda de alcalinizante (no caso, bicarbonato) para a manutenção do $\mathrm{pH}$ foi maior para o tratamento de vinhaça na temperatura termofílica do que na temperatura mesofílica. No tratamento termofílico a relação $\mathrm{HCO}_{3}{ }^{-} / \mathrm{DQO}$ que permitiu a operação estável para a maior COV aplicada foi de 0,4 . No tratamento mesofílico, essa relação foi de 0,2 ;

- Os valores das constantes cinéticas aparentes, obtidos pelo ajuste do modelo cinético de primeira ordem aos dados experimentais de redução de DQO, foram maiores quando o reator foi operado sob condição mesofílica que termofílica. Isso está em desacordo com a literatura a respeito de processos termofílicos anaeróbios, mas é consistente com os dados de desempenho do reator nas condições em que foi operado;

- Ao final da operação dos reatores, observou-se colonização metanogênica predominante de formas semelhantes à arquéias do gênero Methanosarcina sob condição termofílica e Methanosaeta sob condição mesofílica. Embora a composição da microbiota metanogênica possa estar associada ao desempenho do reator nas condições em que foi operado, reatores metanogênicos termofílicos do tipo UASB foram operados de forma eficiente e COV elevadas com a predominância de arquéias do gênero Methanosarcina no lodo biológico. Portanto, a instabilidade observada pode estar associada à conjunção dos fatores composição da biomassa metanogênica e características físicas e operacionais do ASBBR;

- Foi possível adaptar o lodo de reator UASB mesofílico para a operação sob temperatura termofílica de $55^{\circ} \mathrm{C}$ no ASBBR. Essa adaptação transcorreu ao longo de 50 dias após a inoculação. Morfologias semelhantes a células de Methanosaeta e Methanosarcina, bacilos fluorescentes, bacilos delgados, leveduras, bacilos curvos 
semelhantes a bactérias redutoras de sulfato foram observadas no final da fase de adaptação;

- O procedimento adotado para o enriquecimento do lodo mesofílico, com populações metanogênicas, utilizando-se substrato à base de etanol, além de macro e micro nutrientes, mostrou-se adequado;

- O ASBBR tratando substrato sintético semelhante à vinhaça de beterraba mostrou instabilidade operacional sob condição termofílica devido a oscilações da eficiência de remoção de DQO e grande quantidade de ácidos orgânicos no efluente em todas as fases experimentais avaliadas;

- Os ensaios com biomassa granulada suspensa em frascos-reatores apresentaram baixa eficiência de remoção de DQO acompanhada por grande quantidade de ácidos orgânicos no efluente quando operado sob condições termofílicas. Enquanto que, o frasco-reator operado sob condição mesofílica apresentou melhor desempenho atingindo eficiência de remoção de DQO maior que $60 \%$ e maior quantidade de metano no biogás;

- O ensaio de biodegradabilidade anaeróbia do substrato sintético semelhante à vinhaça de beterraba, realizado com o lodo granular mostrou que o potencial de biodegradação foi de $65 \%$ sob condições mesofílicas e de $41 \%$ sob condição termofílica. 


\section{SugeSTÕES PARA TRABALHOS FUTUROS}

"Quando você chegar ao fim de sua corda, dê um

nó e segure-se."

Franklin Roosevelt

Ao longo do desenvolvimento do trabalho e durante a análise dos resultados obtidos, foram observadas diversas questões não esclarecidas por não constituírem objetivos do trabalho ou por não corresponderem aos resultados esperados. Portanto, para trabalhos futuros com tratamento anaeróbio de vinhaça em ASBBR ou outras configurações de reatores, sugerem-se:

- Aplicar nutrientes no final do ciclo da batelada e observar ocorrência de consumo total de ácidos orgânicos e de DQO residual para confirmar a hipótese de deficiência nutricional ao final de ciclos longos;

- Realizar análises de $\mathrm{H}_{2}$ a fim de verificar a relação entre hidrogênio e acúmulo de ácido propiônico no sistema termofílico, pois uma pressão parcial de hidrogênio maior que $10^{-4}$ resulta em acúmulo de propionato no sistema;

- Testar diversas condições de temperatura na faixa termofílica no intuito de definir o melhor desempenho e maior estabilidade operacional, bem como avaliar a influência da agitação, outros materiais suportes, dentre outras condições operacionais;

- Adaptar o inóculo mesofílico a condições termofílicas usando um substrato sintético com etanol, metanol ou acetato como fonte de carbono;

- Monitorar o ASBBR em longo tempo de operação sob condições termofílicas adaptando gradativamente a biomassa à COV maiores e tempo de ciclo fixo; 
- Avaliar diferentes estratégias de alimentação do ASBBR sob condição mesofílica;

- Realizar estudo mais aprofundado sobre microbiologia, bioquímica e química de processos termofílicos para elucidar qual a razão do acúmulo de ácido propiônico, uma vez que, em princípio, as arquéias hidrogenotróficas deveriam converter $\mathrm{H}_{2}$ e $\mathrm{CO}_{2}$ em metano. É possível que o $\mathrm{CO}_{2}$ seja o limitante dessa via metabólica devido provavelmente à baixa solubilidade desse gás nessa faixa de temperatura;

- Recomenda-se o estudo do sistema de duas fases (acidogênese e metanogênese) para o tratamento de vinhaça. A separação de fases poderia permitir que a etapa metanogênica ocorresse de forma mais estável, especialmente no tratamento termofílico;

- Enfocar estudo sobre a composição da vinhaça de cana-de-açúcar com o objetivo de verificar possíveis compostos tóxicos ao tratamento biológico;

- Realizar estudos com reatores de fluxo contínuo no tratamento de vinhaça de cana-de-açúcar. 


\section{REFERÊNCIAS BIBLIOGRÁFICAS}

Ahn, J.H.; Forster, C.F.(2000). A comparison of mesophilic and thermophilic anaerobic upflow filters. Bioresource technology. 73: 201-205.

Ahn, J.H.; Forster, C.F.(2002). A comparison of mesophilic and thermophilic anaerobic upflow filters.treating paper pulp liquors. Process Biochemistry. 38: 257- 262.

Ahring, B.K. (1994). Status on science and application of thermophilic anaerobic digestion. Water Science and Technology, 30 (12), 241-249.

APHA - American Public Health Association, American Watert Works Association, Water Environment Federation (1995). Standard Methods for the Examination of Water and Wastewater. Washington. 19o ed, Washington D.C.

Aquino, S.F., Stuckey, D.C. (2005). Chromatografic characterization of dissolved organics in effluents from two anaerobic reactors treating synthetic wastewater. In: TALLER Y SIMPOSIO LATINOAMERICANO SOBRE DIGESTION ANAEROBIA, 8, 2005, Punta del Este: Uruguay. Proceedings... Punta del Este, IWA. P. 525-530.

Araújo, J. C. (1995). Acompanhamento da evolução do biofilme e caracterização química e biológica em reator de leito fluidificado tratando esgoto sanitário sintético. Tese (Doutorado). Escola de Engenharia de São Carlos, Universidade de São Paulo, São Carlos, SP. 
Balaguer, M.D.; Vicent, M.T.; París, J.M. (1991). Utilisation of pumice stone as support for the anaerobic treatment of vinasse with a fluidized bed reactor. Environmental Technology, 12, 1167-1173.

Balaguer, M.D.; Vicent, M.T.; París, J.M. (1997). A comparison of different support materials in anaerobic fluidized bed reactors for the treatment of vinasse. Environmental Technology, 18, 539-544.

Barker, D.J., Stuckey, D.C. (1999). A review of soluble microbial products (SMP) in wastewater treatment systems. Water Research, 33 (14), 3063-3082.

Bitton, G. (1994). Wastewater microbiology. Wiley-Liss Publ., Gainesville, USA, 478p.

Bolaños, R. M. L., Varesche, M. B. A., Zaiat, M., Foresti, E. (2001). Phenol degradation in horizontal flow anaerobic immobilized biomass (HAIB) reactor under mesophilic conditions. Water Science and Technology, 44, 167-174.

Borges. A.C. (2003). Influência da estratégia de alimentação no desempenho do reator anaeróbio em batelada seqüencial contendo biomassa imobilizada. São Carlos. 170p. Dissertação (mestrado) - Escola de Engenharia de São Carlos, Universidade de São Paulo.

Bouskova, A.; Dohanyos, M.; Schmidt, J.E.; Angelidaki; I. (2005). Stragegies for changing temperature from mesophilic to thermophilic conditions in anaerobic CSTR reactors treating sewage sludge. Water Research, 39, 1481-1488.

Brasil (1978). Portaria MINTER no 323, de 29 de novembro de 1978. Dispõe sobre resíduos, tratamento de residuos, água e alcool, energia combustível. São Paulo, 01p.

Brasil (2005). Resolução CONAMA no 357, de17 de março de 2005. Dispõe sobre a classificação dos corpos de água e diretrizes ambientais para o seu enquadramento, bem como estabelece as condições e padrões de lançamento de efluentes, e dá outras providências. Brasília, 23p. 
Brock, T.D.; Madigan, M.T. (1988). Biology of microorganisms. Prentice Hall. Englewood Cliffs, New Jersey.

Cabirol, N., Fernández, F.J., Mendoza, L., Noyola, A. (2003). Acclimation of mesophilic anaerobic sludge to thermophilic conditions: PCR genera detection methodology. Water Science and Techonology, 48 (6), 81-86.

Camargo, E.F.M. (2000). Tratamento anaeróbio de águas residuárias, em batelada, com microrganismos imobilizados e circulação da fase aquosa. São Carlos. 207p. Dissertação (mestrado) - Escola de Engenharia de São Carlos, Universidade de São Paulo.

Carmo, D.F. (2004). Adaptação de sistema combinado (aeróbio-anaeróbio) da faixa de temperature mesofílica para termofílica visando o tratamento de efluente sintético da indústria de pasta de cellulose não branqueada. Tese (Doutorado). Universidade de São Paulo - Escola de Engenharia de São Carlos, 204p.

Carter, J., Howe, J. (2005). The water framework directive and the strategic environmental assessment directive: exploring the linkages. Environmental Impact Assessment Review, 14p.

Carvalho, G.R. (2006). O setor sucroalcooleiro em perspectiva. Embrapa Monitoramento por Satélite, Campinas. Boletim Conjuntura agropecuária: sucroalcooleiro, março/2006.

Castro Lopes, S.I., Sulistyawati, I., Capela, M.I., Lens, P.N.L. (2005). Thermophilic $\left(55^{\circ} \mathrm{C}\right)$ sulfate reduction at low $\mathrm{pH}(6,5$ and 4$)$ during the acidification of sucrose. In: TALLER Y SIMPOSIO LATINOAMERICANO SOBRE DIGESTION ANAEROBIA, 8, 2005, Punta del Este: Uruguay. Proceedings... Punta del Este, IWA. P. 531-536.

CETESB (2005). P4.231: Vinhaça -critérios e procedimentos para aplicação no solo agrícola. São Paulo, 12p. 
Chen, M. (1983). Adaptation of mesophilic anaerobic sewage fermentor populations to thermophilic temperatures, Applied and Environmental Microbiology, 45 (4), 12711276.

Cho, Y. et al (2004). Rates of activity specific methanogenic. In: TALLER Y SIMPOSIO ANAEROBIC DIGESTION, 2004, Montreal: Canadá. Anais... Montreal, IWA.

Cruz, R.L. (1991). Efeito da aplicação da vinhaça sobre o solo e água subterrânea. Dissertação de Mestrado. Escola de Engenharia de São Carlos.

Cubas, S.A., Foresti, E., Rodrigues, J.A.D., Ratusznei, S.M., Zaiat, M. (2004). Influence of liquid-phase mass transfer on the performance of a stirred anaerobic sequencing batch reactor containing immobilized biomass. Biochemical Engineering Journal, 17, 99-105.

Damianovic, M, Sakamoto, I, Foresti, E. (2005). Biofilm adaptation to sulphate reduction in anaerobic immobillized reactors submitted to different COD/sulphate ratios. In: TALLER Y SIMPOSIO LATINOAMERICANO SOBRE DIGESTION ANAEROBIA, 8, 2005, Punta del Este: Uruguay. Anais... Punta del Este, IWA. P. 537.

Del Nery, V. (1987). Utilização de lodo anaeróbio imobilizado em gel no estudo de partida de reatores de fluxo ascendente com manta de lodo. São Carlos, SP. Dissertação (Mestrado), Escola de Engenharia de São Carlos, USP.

Dilallo,R., Alberton, O.E. (1961). Volatile acids by direct titration. Journal of Water Pollution Control Federation, v. 33, n.4, p. 356-356.

Dinsdale, R.M.; Hawkes, F.R.; Hawkes, D. L. (1997). Comparison of mesophilic and thermophilic upflow anaerobic sludge blanket reactors treating instant coffee production wastewater. Water Research, 31(1): 163-169. 
Driessen, W.J.B.M., Tielbaard, M.H., Vereijken, T.L.F.M. (1994). Experience on anaerobic treatment of distillery effluent with the UASB process. Water Science Technology, v. 30, n. 12, p. 193-201.

Dubourguier, H. C. (1987). Curso ecologia da digestão anaeróbia. Companhia de Tecnologia de Saneamento Ambiental do Estado de São Paulo, CETESB, São Paulo.

Fang, H. P., Chang, O.C. (1997). Toxicity of phenol towards anaerobic biogranules. Water Research, 31 (9), 2229- 2242.

Fdz-Polanco, F.; Fdz-Polanco, M., Fernandez, N.; Urueña, M. A.; Garcia, P. A.; Villaverde, S. (2001). Simultaneous organic nitrogen and sulfate removal in an anaerobic GAC fluidized bed reactor. Water Science and Technology, 44 (4), 15-22.

Fdz-Polanco, F.; Nieto, P., Pére Elvira, S., van der Zee, F.P., García, P.A. (2004). Automated equipment for anaerobic sludge parameters determination. In: TALLER Y SIMPOSIO ANAEROBIC DIGESTION, 2004, Montreal: Canadá. Anais... Montreal, IWA. $432-437$ p.

Fernández, N., Fdz-Polanco, F., Montalvo, S.J., Toledano, D. (2001). Use of activated carbon and natural zeolite as support materials, in an anaerobic fluidized bed reactor, for vinasse treatment. Water Science and Technology, 44 (4), p. 1-6.

Ferreira, E.S.; Monteiro, A. O. (1986) Efeitos da aplicação da vinhaça nas propriedades químicas, físicas e biológicas do solo. São Paulo: Boletim Técnico Coopersucar, 9 p.

Field, J., Sierra-Alvarez, R., Lettinga, G. (1988). Ensayos Anaeróbios. Actas del Seminario Depuración anaerobia de aguas residuales, 4, Departamento de Ingeniería Química: Universidad de Valladolid, 52-81.

Gazeta mercantil (2005). Agronegócio - triplica exportação de álcool em 2004. 13 jan./2005 Disponível em : http://www.global21.com.br/materiais/materia. Acesso em: 09 fev. 2005 
Gillan, D.C., Speksnijder, A.G.C.L., Zwart, G., Ridder, C. (1998). Genetic diversity of the biofilm covering Montacuta feruginosa (Mollusca, Bivalvia) as evaluated by denaturing gradient gem electrophoresis analysis and cloning of PCR-amplified gene fragments coding for 16S rRNA. Applied and Envoronmental Microbiology, 64 (9), 3464-3472p.

Griffin, M.E.; McMahon, K.D.; Mackie, R. I.; Raskin, L. (1998). Methanogenic population dynamics during start-up of anaerobic digesters treating municipal solid waste and biosolids. Biotechnology and Bioengineering, 57 (3), 342-355.

Großkopf, R., Janssen, P.H., Liesack, W. (1998), Diversity and structure of the methanogenic community in anoxic rice paddy soil microcosms as examined by cultivation and direct 16S rRNA gene sequence retrieval, Applied and Environmental Microbiology, 64, 960-969.

Guerrero, L; Omil, F.; Méndez, R.; Lema, J.M. (1999). Anaerobic hydrolysis and acidogenesis of wastewaters from food industries with high content of organic solids and protein. Water Research. 33(15): 3281-3290.

Kennedy, K.J.; Sanchez, W.A.; Hamoda, M.F.; Droste, R.L. (1991). Performance of anaerobic sludge blanket sequencing batch reactors. Research Journal of Water Pollution Control Federation, 63, 75-83.

Kerner, S., Rochard, J. (2004). Winery watewater treatment by constructed wetlands: principles and prospects. In.: International Conference on Waste Stabilisation Ponds,6, and International Conference on Wetland Systems for Water Pollution Control, 9, Avignon, France. Anais, France. 105-110.

Harper, S.R., Pohland, F.G. (1986). Recent development in hydrogen management during wastewater treatment. Biotechnology and Bioengineering, 28, 585-602

Harada, H.; Uemura, S.; Chen, A. C.; Jayadevan. (1996). J. Anaerobic treatment of recalcitrant distillery wastewater by a thermophilic UASB reactor. Bioresource Technology, 55, 215 - 221. 
Harris, W.L., Dague, R.R. (1993). Comparative performance of anaerobic filters at mesophilic and thermophilic temperatures. Water Environmental Research. 65, 764771.

Hollopeter, J.A.; Dague, R.R. (1994). Anaerobic sequencing batch reactor treatment of landfill leachate. In: PURDUE INDUSTRIAL WASTE CONFERENCE, 49, Chelsea. Proceedings. Ann Arbor Press: Michigan, pp. 277-284.

Jaenicke, R. Sterner, R. (2006). Life at high temperatures. In Dworkin, M. et al. (eds.), The Prokaryotes: An Evolving Electronic Resource for the Microbiological Community, ed. 3, liberação 3.9, Janeiro 4, 2002, Springer-Verlag: New York, http://link.springerny.com/link/service/books/10125/.

Jiménez, A.M., Borja, R., Martín, A. (2003). A comparative kinetic evaluation of the anaerobic digestion of untreated molasses and molasses previously fermented with Penicillium decumbens in batch reactors. Biochemical Engineering Journal. (no prelo). www.elsevier.com/locate/bej

Lalov, I. G.; Krysteva, M.A.; Phelouzat, J. L. (2001). Improvement of biogas production from vinasse via covalent immobilized methanogens. Bioresource Technology, 79, p. 83 $-85$.

Lapa, K.R. (2003). Avaliação de desempenho do reator anaeróbio em batelada seqüencial (ASBR), contendo biomassa imobilizada em pedra pome, para tratamento de esgoto sanitário. São Carlos. 106p. Dissertação (mestrado) - Escola de Engenharia de São Carlos, Universidade de São Paulo.

Loropeza, C., Ponsb, M.N., Morgenrotha, E.C. (2006). Endogenous processes during long-term starvation in activated sludge performing enhanced biological phosphorus removal. Water Research, 40 (8), 1519-1530 . 
Luz, P.H.C. (2005). Novas tecnologías no uso da vinhaça e alguns aspectos legais.In: SIMPOSIO DE TECNOLOGIA DE PRODUÇÃO DE CANA-DE-AÇUCAR, 2, Anais...São Paulo, 2005. 1-53p.

Madejón, E., López, R., Murillo, J.M., Cabrera, F. (2001). Agricultural use of three (sugar-beet) vinasse composts: effect on crops and chemical proprieties of a Cambisol in the Guadalquivir river valley (SW Spain). Agriculture Ecosystems and Environment, 84 , p. 55-65.

Madigan, M.T., Martinko, J. \& Parker, J. (1998). In: Brock T.D. (ed.) Biology of Microorganisms. 8th edition. Prentice Hall International, Inc. New Jersey. 986 p.

Madigan, M. T., Martinko, J. M. \& Parker, J. (2004). Microbiologia de Brock. 10ed. São Paulo: Prentice Hall, 608p.

Massé, D.I.; Masse, L. (2001). The effect of temperature on slaughterhouse wastewater treatment in anaerobic sequencing batch reactors. Bioresource Technology, 76: 91-98.

Moraes, E. de M.; Foresti, E.; Zaiat, M.; Adorno, M.A.T. (2001). Determinação de ácidos voláteis por cromatografia gasosa em efluentes de reatores anaeróbios. In: Chernicharo, C.A.L. (coord.). Pós-tratamento de efluentes de reatores anaeróbios: aspectos metodológicos. Belo Horizonte: Prosab. p. 35-39

Moosbrugger, R.E., Wentzel, M.C., Ekama, G.A., Marais,G.V.R. (1993). Treatment of wine distillery waste in UASB systems - feasibility, alkalinity requirements and $\mathrm{pH}$ control. Water Science and Technology, 28 (2), p. 45-54.

Mutton, M.J.R., Mutton, M.A. (2002). Curso para formação de multiplicadores para produção de cachaça de qualidade, Jaboticabal: FUNEP, 126p.

Muyzer, G. (1999). DGGE/TGGE a method for identifying genes from natural ecosystems. Curr. Opin. Microbiol. 2, 317-322. 
Nation, J. L. (1983). A new method using hexamethyldilazane for preparation of soft tissues for scanning electron microscopy. Stain Technol., 58, 347-351.

$\mathrm{Ng}$, W.J. (1989). A sequencing batch anaerobic reactor for treating piggery wastewater. Biological Wastes, 28, pp. 39-51.

Nübel, U., Engelen, B., Felske, A., Snaidr, J,. Wieshuber, A., Amann, R.I., Ludwig, W., Backhaus, H. (1996), Sequence heterogeneities of genes encoding 16S rRNAs in Paenibacillus polymyxa detected by temperature gradient gel electrophoresis, Journal of Bacteriology. 178, 5636-5643.

Olmo, L. (2006). Avaliação do antagonismo do efeito do sódio sobre o tratamento de água residuária de charqueada com elevada salinidade em reator anaeróbio de manta de lodo (uasb). São Carlos. 79p. Dissertação (mestrado) - Escola de Engenharia de São Carlos, Universidade de São Paulo.

Ometto, A.R. (2000). Discussão sobre os fatores ambientais impactados pelo setor sucroalcooleiro e a certificação socioambiental. São Carlos. 255p. Dissertação (mestrado) - Escola de Engenharia de São Carlos, Universidade de São Paulo.

Oropeza, M. R.; Cabirol, N., Ortega, S., Ortiz, A.P.C.; Loyola, A. (2001). Removal of fecal indicador organisms and parasites (fecal coliforms and helminth eggs) form municipal biologic sludge by anaerobic mesophilic and thermophylic digestion. Water Science and Technology, 44 (4), 97-101.

Öztürk, M. (1991). Conversion of acetate, propionate and butyrate to methane under thermophilic conditions in bath reactors. Water Science and Technology, 25, 1509-1513.

Pagel, G. (2006). Setor sucroalcoleiro: mudança de cenário e boas perspectivas. Sociedade Rural Brasileira, 3p. Disponível em: http://www.srb.org.br/ Acessado em 07/10/2006. 
Paulo, P.L., Villa, G., Van Lier, J.B., Lettinga, G. (2003). The anaerobic conversion of methanol under thermphilic conditions: $\mathrm{pH}$ and bicarbonate dependence. Journal of Bioscience and Bioengineering, 96 (3), 213-218.

Pender, S., Toomey, M., Carton, M., Eardly, D., Patching, J.W., Colleran, E., O'Flaherty, V. (2004). Long-term effects of operating temperature and suphate addition on the methanogenic community structure of anaerobic hybrid reactors. Water Research, 38, 619-630.

Pérez, M.; Romero, L. I.; Sales, D. (1999). Anaerobic thermophilic fluidized bed treatment of industrial wastewater: effect of F:M relationship. Chemosphere. 38 (14), p. $3443-3461$.

Pelczar Jr., M.; Reid, R.; Chan, E. C. S. (1986). Microbiologia. v. 1. São Paulo, São Paulo. McGraw-Hill. 566p.

Pohland, F.G., Ghosh, S. (1971), Development in anaerobic stabilization of organic wastes - The two-phase concept. Environmental Letters, 1 (4), 255.

Postgate, J.R. (1984). The sulphate-reducing bacteria. , $2^{\text {nd }}$ ed, Cambridge: Cambridge university Press.

PRONAF (2006). Programa Nacional de Fortalecimento da Agricultura Familiar. Canade-açúcar, 7p. Disponível em: http://www.pronaf.gov.br/ Acessado em 03/2006.

Rajeshwari, K.V., Balakrishnan, M. Kansal, A., Kusum Lata, Kishore, V.V.N. (2000). State-of-the-art of anaerobic digestion technology for industrial wastewater treatment. Renewable and Sustainable Energy Reviews, 4, 135-156.

Ratusznei, S.M., Rodrigues, J.A.D., Zaiat, M. (2003). Operating feasibility of anaerobic whey treatment in a stirred sequencing batch reactor containing immobilized biomass. Water Science and Technology, 48 (6), 179 - 186. 
Ripley, L.E., Boyle, W.C., Converse, J.C. (1986). Improved alkalimetric monitoring anaerobic digestion of high-strenght wastes. Journal Of Water Pollution Control Federation, v. 58, p. 406-411.

Ruiz, C., Torrijos,M., Sousbie, P., Lebrato Martinez, J., Moleta, R., Delgenés, J.P. (2001). Treatment of winery wastewater by ab anaerobic sequencing batch reactor (ASBR). In: World Congress of Anaerobic Digestion, 9, Antuérpia. Proceedings, 347353.

Ruiz, C. (2002). Aplicación de digestores anaeróbios discontinuos em el tratamiento de águas residuales industriales. Tese (Doutorado). Universidad de Sevilla, 218p.

Santos, M.B. dos. (2000). Proposta metodológica para o planejamento do uso agrícola da vinhaça, considerando os seus aspectos ambientais, por meio de sistema de informações geográficas. São Carlos. 123p. Dissertação (mestrado) - Escola de Engenharia de São Carlos, Universidade de São Paulo

Speece, R.E. (1996). Anaerobic biotechnology for industrial wastewater treatment. Archae Press, Nashville, 394p.

Sérvulo, E. F. C. (1991). Ação das bactérias oxidantes e redutoras de enxofre sobre o xisto. Rio de Janeiro. 148p. Tese (Doutorado) - Instituto de Microbiologia, Universidade Federal do Rio de Janeiro.

Sipma J.; Lens, P.N.L.; Vieira, A.; Miron, Y.; Van Lier, J.B.; Hulshoff Pol, L.; Lettinga, G. (2000). Thermofilic sulfate reduction in UASB reactors under acidifying conditions. Process Biochemistry, 35. 509-522.

Sneath, P.H.A. (1986). Endospore-forming Gram Positive Rods and Cocci. Bergey's Manual of Systematic Bacteriology, USA: William \& Wilkins. 2 (13), 1104-1207.

Song, Y.C., Kwon, S.J., Woo, J.H. (2004). Mesophilic and thermophilic temperature cophase anaerobic digestion compared with sigle-stage mesophilic and thermophilic digestion of sewage sludge. Water Research, 38, 1653-1662. 
Souza, M. E.; Fuzaro, G.; Polegato, A. R. (1992). Thermophilic anaerobic digestion of vinasse in pilot plant uasb reactor. Water Science Technology, 25 (7): 213-222

Springer, A., Goissis, G. (1988). Design of pond systems for treatment of ethanol plant effluents. Biological Wastes, 23, 143-152.

Steil, L. (2001). Avaliação do uso de inóculos na biodigestão anaeróbia de resíduos de aves de postura, frangos de corte e suínos. Araraquara. Dissertação (Mestrado), UNESP.

Syutsubo, K., Sinthurat, N., Ohashi, A., Harada, H. (2001). Population dynamics of anaerobic microbial consortia in thermophilic granular sludge in response to feed composition change. Water Science Technology, 43 (1), 59-66.

Tehl, M. (2001). Avaliação do uso de reator anaeróbio horizontal de leito fixo no tratamento da vinhaça sob condições termofílicas. São Carlos. 60p. Dissertação (mestrado) - Escola de Engenharia de São Carlos, Universidade de São Paulo.

Torres, P., Pérez, A., Cajigas, A.A., Otero, A.M., González, M. (2005). Evaluación de diferentes alcalinizantes en el tratamiento anaerobio de aguas residuales fácilmente acidificables. Caso: agua residual del proceso de extracción de almidón de yuca. In: TALLER Y SIMPOSIO LATINOAMERICANO SOBRE DIGESTION ANAEROBIA, 8, 2005, Punta del Este: Uruguay. Anais... Punta del Este, IWA. P. 571-575.

Torrijos, M. and Moletta, R. (1997). Winery wastewater depolution by sequencing batch reactor. Water Science and Technology. 35 (1): 249-257.

Touzel, J. P., Albagnac, G. (1983). Isolation and characterization of Methanococcus mazei strain MC3. FEMS Microbiology Letters, 16: 241-245.

Tripathi, C. S.; Allen, D. G. (1999). Comparison of Mesophilic and Thermophilic aerobic biological treatment in sequencing batch reactors treating bleached kraft pulp mill effluent. Water Research, 33(3): 836-846 
Uemura, S.; Harada, H. (1993). Microbial characteristics of methanogenic sludge consortia develop in thermophilic UASB reactors. Applied Microbiology Biotechnology, 48, 534-538.

Vaccari, G.; Tamburini, E.; Sgualdino, G.; Urbaniec, K.; Klemes, J. (2003). Overview of the environmental problems in beet sugar processing: possible solutions. Journal of Cleaner Production.

Van Lier, J.B., Macario, A.J.L., Conway de Macario, E., Lettinga, G. (1992). Permanent increase of the process temperature of mesophilic upflow anaerobic sludge bed (UASB) reactors to 46, 55, 64 and 75o C. In: C.S. Dalton and R.F. Wukasch (ed.). Proceedings of Industrial Waste conference, 47th, 1992. Lafayette, Indiana, USA. Lewis Publishers, Chelsea Michigan, USA, p. 445-459.

Van Lier, J.B., Hulsbeek, J., Stams, A.J.M., Lettinga, G. (1993). Temperature susceptibility of thermophilic methanogenic sludge: implications for reactor start-up and operation. Bioresource Technology, 43, 227-235.

Van Lier, J.B. (1993). Digestión anaerobia termofilica: aspectos relacionados con la temperature. Actas del Seminario Depuración anaerobia de aguas residuales, 5, Departamento de Ingeniería Química: Universidad de Valladolid, 12 p.

Van Lier, J.B. (1995).Thernophilic anaerobic wastewater treatment; temperature aspects and process stability. Tese (Doutorado). Wageningen University, 181p.

Van Lier, J.B. (1996). Limitations of thermophilic anaerobic wastewater treatment and the consequences for process design, Antonie van Leeuwenhoek, 69, 1-14.

Van Lier, J.B.; Martin, J.L.S.; Lettinga, G. (1996). Effect of temperature on the anaerobic thermophilic conversion of volatile fatty acids by dispersed and granular sludge. Water Research. 30(1): 199-207. 
Van Lier, J. B.; Rebac, S.; Lettinga, G. (1997). High-rate anaerobic wastewater treatment under psychrophilic and thermophilic conditions. Water Science Technology. 35(10): 199-206.

Varesche, M.B.A., Zaiat, M., Vieira, L.G.T., Vazoller, R.F., Foresti, E. (1997).Microbial colonization of polyurethane foam matrices in horizontal-flow anaerobic immobilized-sludge reactor. Applied Microbiology and Biotechnology, 48: 534-538.

Vassoughi, M.; Shakeri, M.; Alemzadeh, I. (2003). Performance of anaerobic baffled reactor treating synthetic wastewater influnced by decreasing $\mathrm{COD} / \mathrm{SO}_{4}$ ratios. Chemical Engineering and Processing, 42, 811-816.

Vazoller, R. F. (1995). Avaliação do ecossistema microbiano de um biodigestor anaeróbio de fluxo ascendente e manta de lodo, operado com vinhaça sob condições termofílicas. Tese (doutorado). Universidade de São Paulo - Escola de Engenharia de São Carlos. São Carlos. 259p.

Vazoller, R. F. (1997). Microbial aspects of thermophilic anaerbic biodigestion of vinasse. Novel Trends In Biologycal Wastewater, 527 - 532.

Viana, A.B. (2006). Tratamento termofílico de vinhaça em reator UASB. Dissertação (Mestrado). Universidade de São Paulo - Escola de Engenharia de São Carlos. São Carlos. 60p.

Vich, D.V. (2006). Avaliação da atividade metanogênica e comunidade microbiana envolvidas na degradação de metilamina. Dissertação (Mestrado). Universidade de São Paulo - Escola de Engenharia de São Carlos. São Carlos. 80p.

Vlissidis, A. and Zouboulis, A. I. (1993). Thermophilic anaerobic digestion of alcohol distillery wastewaters. Bioresource Technology, 43: 131-140. 
Wiegant, W.M.; Lettinga, G. (1985). Thermophilic anaerobic digestion of sugars in upflow anaerobic sludge blanket reactors. Biotechnology and Bioengineering, 27: 16031607.

Wiegant, W.M., Claassen, J.A., Lettinga, G. (1986). Thermophilic anaerobic digestion of high strength wastewaters. Biotechonology and Bioengineering, 37, 1374-1381.

Wilkie, A. C.; Riedesel, K. J.; Owens, J. M. (2000). Stillage characterization and anaerobic treatment of ethanol stillage from conventional and cellulosic feedstocks. Biomass and Bioenergy, 19: 63 - 102.

Wu, W.M., Jain, M.K., Thiele, J.H., Zeikus, J.G. (1995). Effect of storage on the performance of methanogenic granules. Water Research, 29 (6), 1445-1452p.

Zaiat, M.; Cabral, A.K.A.; Foresti, E. (1994). Horizontal-flow anaerobic immobilized sludge reactor for wastewater treatment: conception and performance evaluation. Revista Brasileira de Engenharia - Caderno de Engenharia Química, 11, 33-42

Zaiat, M.; Rodrigues, J.A.D.; Ratusznei, S.M.; Camargo, E.F.M.; Borzani, W. (2001). Anaerobic sequencing batch reactors for wastewater treatment: A developing technology. Applied Microbiology and Biotechnology, 55: 29 - 35

Zábranská, J., Dohányos, M., Jenícek, P., Zaplatíková, P., Kutil, J. (2002). The contribution of thermophilic anaerobic digestion to stable operation of wastewater sludge treatment. Water Science and Technology, 46 (4-5), 447-453.

Zinder, S. H., Cardwell, S. C., Anguish, T., Lee, M., Koch, M. (1984). Methanogenesis in a thermophilic $\left(58{ }^{\circ} \mathrm{C}\right)$ anaerobic digestor. Methanothrix sp. as an important acetoclastic methanogen. Applied and Environmental Microbiology, 47, 796-807 